\title{
Fossil Algae From
}

Eniwetok, Funafuti

\section{and Kita-Daitō-Jima}

GEOLOGIGAL SURVEY PROFESSIONAL PAPER 260-Z

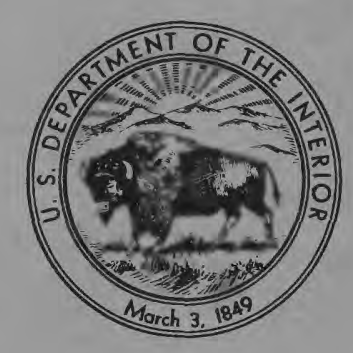


Fossil Algae From

Eniwetok, Funafuti

and Kita-Daitō-Jima

By J. HARLAN JOHNSON

BIKINI AND NEARBY ATOLLS, MARSHALL ISLANDS

GEOLOGICAL SURVEY PROFESIONAL PAPER 260-Z

A description of 90 species, including 4 new ones, belonging to I6 genera, and a discussion of the value of algae as paleoecological indicators and rock builders

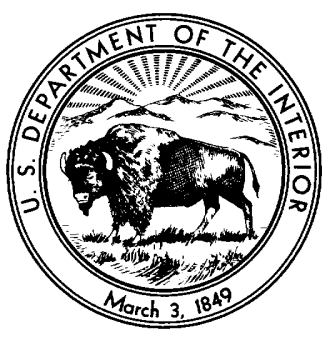

UNITED STATES GOVERNMENT PRINTING OFFICE, WASHINGTON : 1961 
UNITED STATES DEPARTMENT OF THE INTERIOR

STEWART L. UDALL, Secretary

GEOLOGICAL SURVEY

Thomas B. Nolan, Director

For sale by the Superintendent of Documents, U.S. Government Printing Office Washington 25, D.C. 


\section{CONTENTS}

Abstract

Introduction

Source of material .......................

Eniwetok Atoll, Marshall Islands...........

Funafuti Atoll, Ellice Islands_...............

Kita-Daitō-Jima, Philippine Sea ............

Procedure

Acknowledgments................

Classification

Keys to the tribes and genera of the crustose coralline

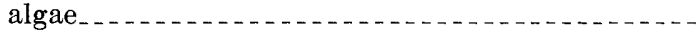

Keys to the genera of the articulated coralline algae _

Distribution and abundance....................

Crustose coralline algae

Articulate coralline algae . . . . . . . . . . . . . . . .

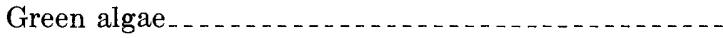

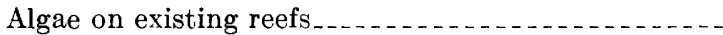

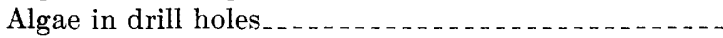

Algae as limestone builders

Algae as indicators of age . . . . .

Algae as ecological indicators... . . . . . . . . . . . . .

Systematic descriptions._.

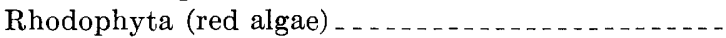

Family Corallinaceae (coralline algae) ........

Subfamily Melobesioideae (crustose

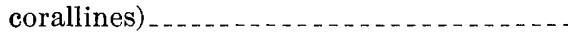

Genus Archaeolithothamnium Roth-

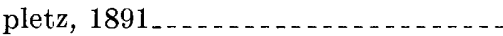

Division 1-Simple crusts......

Division 2-Crusts with protuberances or short stubby branches_

Division 3--Strongly branching

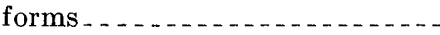

Genus Lithothamnium Phillippi, 1837.

Division 1-Simple crusts........

Division 2-Crusts with warty protuberances or short stubby branches.....................

Division 3-Strongly branching forms ..........................

Genus Mesophyllum Lemoine, 1928_..

Division 1-Simple crusts........

Division 2-Crusts with short stubby branches.............

Division 3-Strongly branching forms .

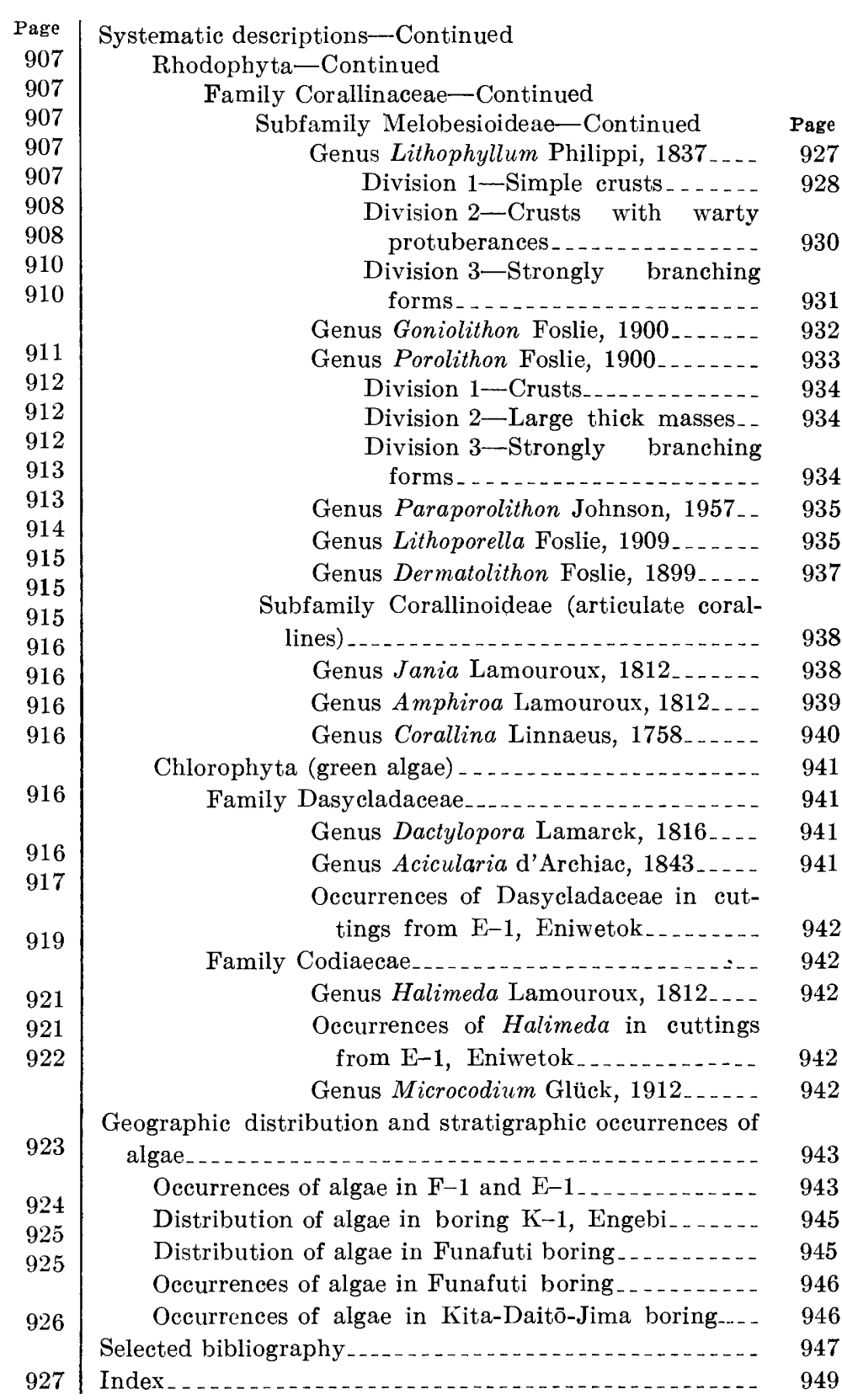

\section{L L U S T R A T I ON S}

Plate 267. Archaeolithothamnium.

268. Archaeolithothamnium.

269. Archaeolithothamnium and Lithothamnium.

270. Lithothamnium and Mesophyllum.

271. Mesophyllum.

272. Lithophyllum and Mesophyllum.

273. Lithophyllum.

274. Lithophyllum.
[Plates follow index]

Plate 275. Porolithon, Goniolithon, and Lithophyllum.

276. Lithoporella.

277. Corallina, Amphiroa, Dermatolithon, and Lithoporella.

278. Amphiroa, Jania, and Dactylopora.

279. Halimeda, Dactylopora, and Acicularia.

280. Halimeda.

Figure 288. Sites of deep holes drilled on coral islands 



\title{
FOSSIL ALGAE FROM ENIWETOK, FUNAFUTI, AND KITA-DAITŌ-JIMA
}

\author{
By J. Harlan Johnson
}

\begin{abstract}
Ninety species belonging to sixteen genera of calcareous algae are described and discussed. Four of the species are new. Most of the algae were obtained from holes drilled on Eniwetok, Funafuti, and Kita-Daitō-Jima; a few from outcrop samples. The several habitats occupied by algae on the existing reefs are briefly described. Algae are shown to have value as paleoecological indicators. They have contributed notably as rock builders.

The rocks containing the algae have been dated as: Recent and Pleistocene(?), Miocene, and Eocene. The algal floras from these units are quite distinct. Many of the species observed growing on the existing reefs occur in the Pleistocene(?) limestones along with some additional forms. With the exception of the highly variable form designated as Lithoporella melobesioides (Foslie) Foslie, the Recent-Pleistocene(?), Miocene, and Eocene floras have no species in common.

Charts show the known geographic and geologic distribution of species. Details of the stratigraphic distribution of the algae in the drill holes are appended at the end of the report.
\end{abstract}

\section{INTRODUCTION}

Since the end of World War II, geological studies of many of the Pacific Islands have been made by the U.S. Geological Survey. In connection with this work, the author visited a number of the islands and collected both living and fossil algae. He has also studied the large collections of algae made by the parties engaged in mapping the islands and has studied material from all the deep holes that have been drilled into Pacific island reefs.

Descriptions of the living and fossil algae from Bikini Atoll have been published by Taylor (1950) and Johnson (1954). Descriptions of fossil algae from Saipan have been published by Johnson (1957).

The present paper presents information obtained from studies of samples from deep holes drilled on Eniwetok, Funafuti, and Kita-Daitō-Jima and some comparisons with samples from Bikini. Drill holes on these four islands are the only ones that have penetrated deeply enough to give significant information as to the foundations of the atolls and their geologic history. Samples from all holes contain calcareous algae, and at certain levels such algae are extremely abundant. The four drilling localities are widely distributed geographically, and are separated by a considerable range of latitude (fig. 288). All but one of the holes penetrate rocks older than Pleistocene. The Eniwetok holes pass through 1,500 feet of Eocene rock.
The present study indicates that algae have contributed notably to reef construction.

Insofar as possible, the data on the algae from the various islands has been synthesized, and the species descriptions have been arranged systematically.

\section{SOURCE OF MATERIAL}

This report is based on the limestone cores and cuttings obtained from the drill holes on Eniwetok, Funafuti, and Kita-Daitō-Jima.

\section{ENIWETOK ATOLL, MARSHALL ISLANDS}

Drilling on Eniwetok Atoll began in 1951 when several holes were drilled on the island of Engebi. One of these $(\mathrm{K}-1 \mathrm{~B})$ was carried to a depth of 1,285 feet. The following year two deep holes were drilled, each of which went to the underlying volcanic rock basement. The first, F-1 on Elugelab, struck the basement rock at a depth of 4,610 feet. The second, E-1 on Parry Island, reached a total depth of 4,222 feet, having penetrated 68 feet of basalt (fig. 289). Drill holes $\mathrm{F}-1$ and $\mathrm{E}-1$ are the deepest yet made in a coral reef, and are the only ones that have penetrated to the basement material. The holes passed through a relatively thin Quaternary section before entering a thick Tertiary section of shallow-water limestones.

Many of the beds penetrated by the drill were very fossiliferous. The most abundant fossils are Foraminifera, corals, mollusks, and algae. A detailed discussion of the stratigraphy and descriptions of the other groups of fossils are contained in other chapters of Professional Paper 260.

\section{FUNAFUTI ATOLI, FLLICE ISLANDS}

Drilling on Funafuti was done between 1896 and 1898. The final report on the project was published as an illustrated memoir by the Royal Society of London in 1904 and is recognized as a classic in geology. Members of the Royal Society who made the study discussed the petrography and alteration of the rocks, and described in detail most of the organisms found in cores and cuttings. One group not studied or described was the calcareous algae. They recognized the presence of these organisms, but no specialist was available for detailed study so they were lumped under the general term, Lithothamnion. 


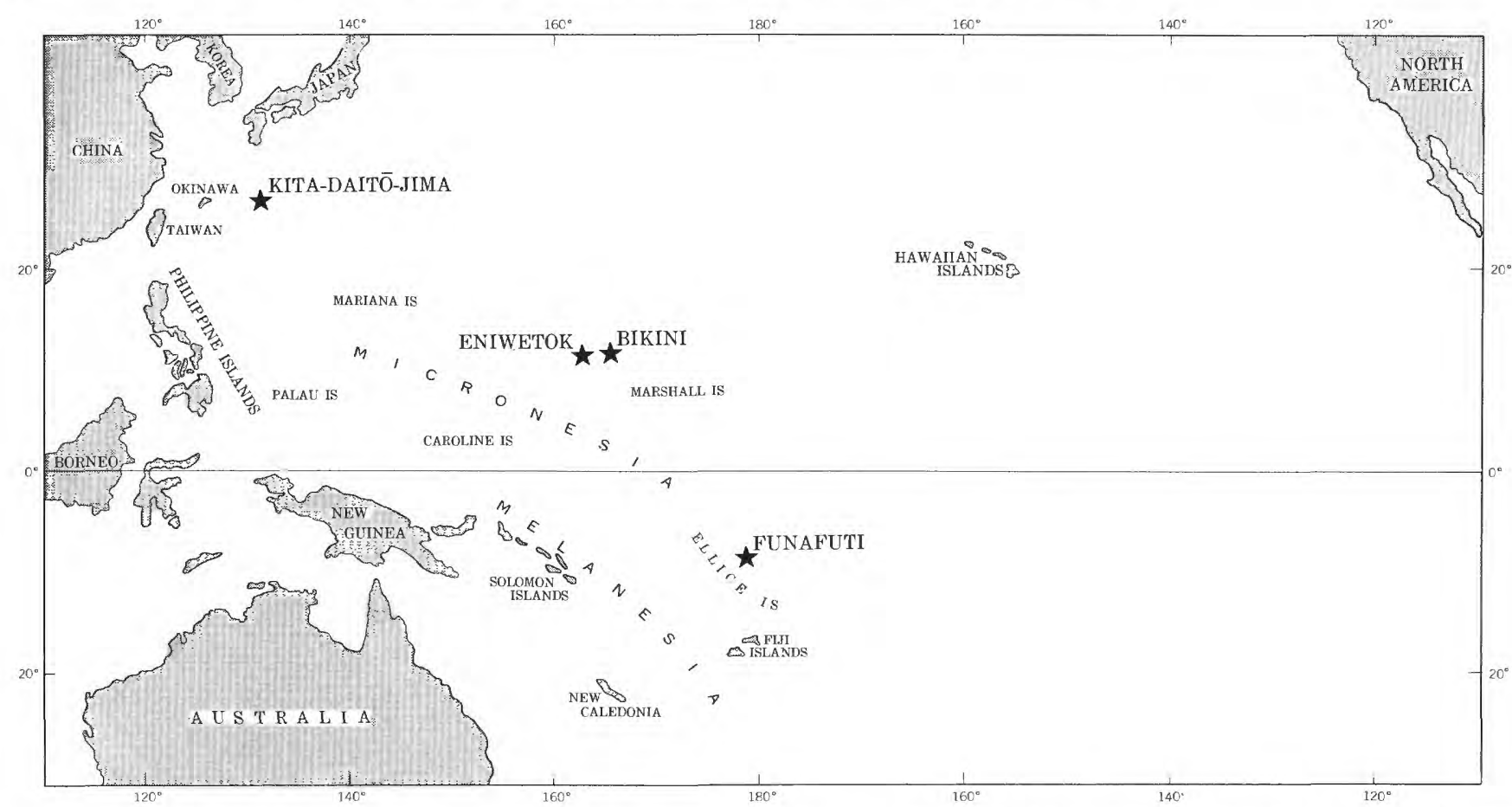

Figure 288. - Sites of deep drill holes-Eniwetok, Funafuti, and Kita-Daitō-Jima (position of Bikini also shown; algae described in Professional Paper 260-M).

After the deep drilling on Bikini had been completed, the authorities of the British Museum loaned the Funafuti cores to the writer for comparative studies, and he welcomed the opportunity to examine the algae.

The main boring at Funafuti (drilled in 1897-98) penetrated to a depth of 1,114 feet. Throughout its length the hole was in carbonate rocks: limestone, dolomitic limestone, and dolomite. No Tertiary sediments were reached. Considering the date at which the drilling was done and the type of equipment then available, the expedition made a remarkable recovery of cores. Most of the section was in hard rock, although some of the youngest beds were friable and incoherent "sands." In the deeper portions of the boring, the limestone was found to be recrystallized and highly dolomitized. Unfortunately, the alteration destroyed detailed structures of many fossils.

The abundance of algae found in the cores surprised all the geologists who took part in the investigation. Statements in the report regarding the importance of algae have been quoted in many later publications and have stimulated considerable work on calcareous algae.

\section{KITA-DAITŌ-JIMA, PHILIPPINE SEA}

A drilling project on Kita-Daitō-Jima was sponsored by Professor H. Yabe of Tōhoku University. The work began in March 1934 and continued for about 6 weeks, when a depth of 209.29 meters ( 687 feet) was reached. The project was resumed in January 1936 and the drilling continued to a total depth of $431.6 \mathrm{~T}$ meters (1,416 feet). The work ended May 24, 1936. The section drilled first was mainly hard limestone, and core recovery was very good. In the second operation, the hole penetrated poorly consolidated material. The cores and cuttings were taken to Tōhoku University at Sendai, Japan, where they were studied. Reports on the petrology of the limestones have been published by Y. Ota in 1938, and S. Hanzawa described the Foraminifera in 1941. In these reports, repeated mention is made of the calcareous algae as important constituents of the calcareous sediments, but no species were described.

The authorities at Tōhoku University, through Professor Shoshiro Hanzawa, generously donated half of the entire core to the U.S. Geological Survey. This core is now on permanent deposit at the U.S. National Museum. The University authorities also loaned their thin sections. Numerous additional sections were prepared from parts of the core; the algae found in the sections are described in this report.

\section{PROCEDURE}

Genera of crustose coralline algae are differentiated on the basis of the character and structure of the hypothallus and perithallus and in the structure and arrangement of the sporangia and conceptacles. Species 


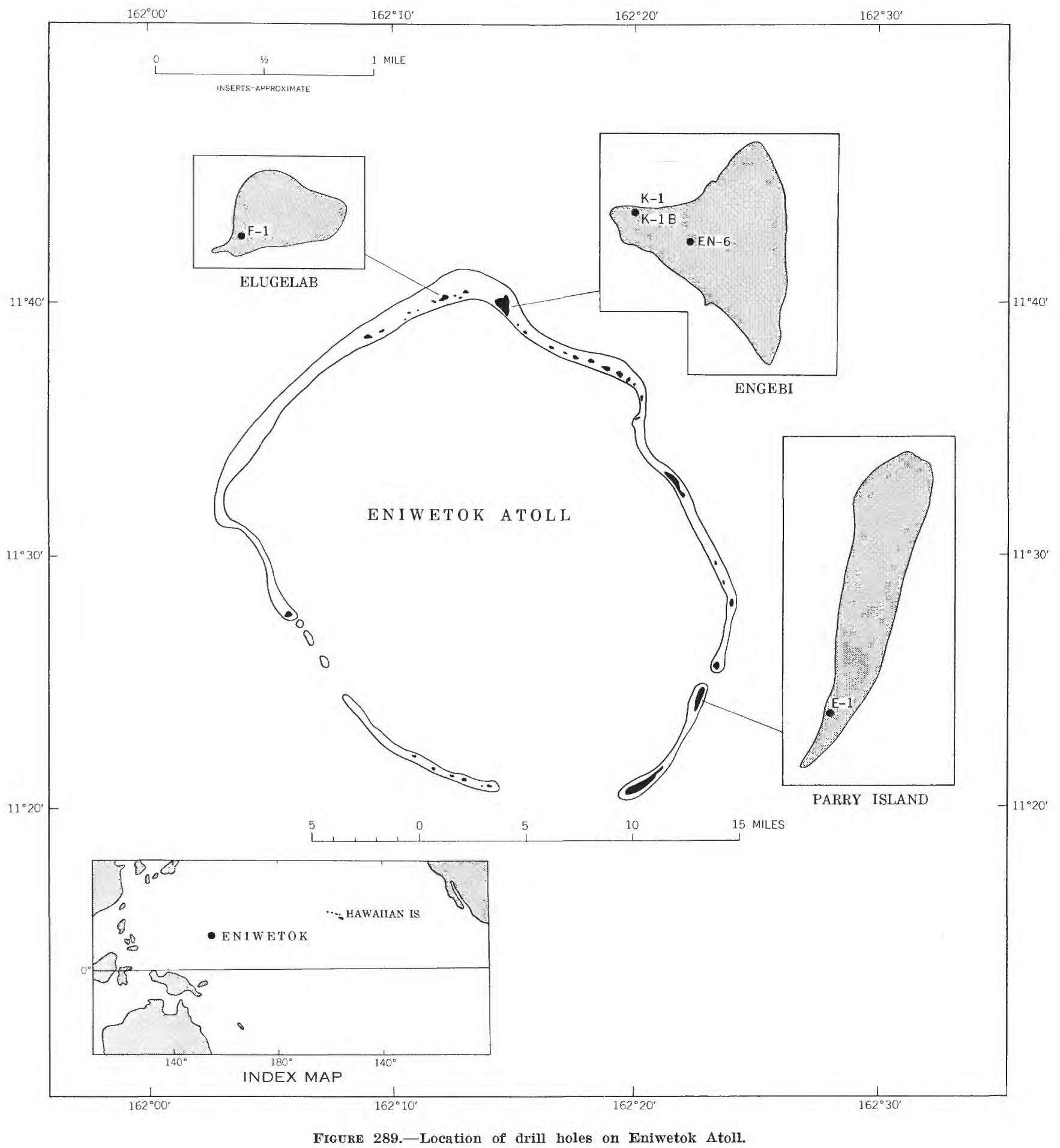

are differentiated on dimensions of cells and conceptacles.

Numerous thin sections were prepared from various cores and from pieces of calcareous algae picked from drill cuttings. Each of the Eniwetok cores bears a letter designating the hole, followed by three numbers. The first number is that assigned to the hole, the second refers to the number of the core run, and the third the number of the core piece, counted from the top of the core. In the laboratory innumerable cell measurements were made and the thickness of the crusts, hypothallus, perithallus, and conceptacles measured. Many of the data obtained are summarized in tables. 


\section{ACKNOWLEDGMENTS}

Thanks are due the authorities of the British Museum of Natural History for the arrangements which permitted a restudy of the Funafuti core and the original slides made from it. Miss L. M. Newton of that institution prepared a list of the Recent calcareous algae from Funafuti determined by M. H. Foslie, which are now in the collections of the British Museum.

Dr. Earling Siversten, Director, and Dr. Olav Gjaerevoll, Curator of Botany, at the Royal Norwegian Natural History Society's Museum at Trondheim, Norway greatly assisted the writer during a visit to the Museum in 1950. The Funafuti collections studied by M. H. Foslie, including a number of type specimens, were made available for examination and photography and small fragments were furnished for thin sectioning. Most of the photographic plates from which the illustrations for the Foslie and Prinz Memoir (1929) were prepared were also located.

In addition to arranging for loan of Kita-DaitōJima material, Dr. Shoshiro Hanzawa of the Institute of Geology and Paleontology of Tōhoku University, Sendai, Japan, personally assisted the writer most generously during several visits to Japan.

To Wataru Ishijima, Professor of Geology, Rikkyo (St. Paul's) University, Tokyo, Japan, and the foremost student of fossil coralline algae in Japan, the author is deeply grateful for many courtesies and kindnesses. His recent publication "Cenozoic Coralline Algae from the Western Pacific" (1954) has been frequently consulted.

\section{CLASSIFICATION}

Algae are classified into broad general divisions or phyla on the basis of the structure of the plants, and the chemical character of their normal pigments. The several phyla having fossil representatives are shown in the following table. All the rock-building algae described in the present report belong to 1 of 2 of the major divisions, the Rhodophyta (red algae) or the Chlorophyta (green algae). The classification of genera used is given in the table on classification. Generic identification keys are given later.

The important rock-building red algae belong to the family Corallinaceae, or coralline algae. These differ from the other calcareous algae in that the calcium carbonate is secreted within and between the cell walls as well as (in most specimens) being deposited around the plant tissues. For this reason, they make good fossils as they show recognizable and specifically identifiable microstructure such as the shape and arrangement of the cells.

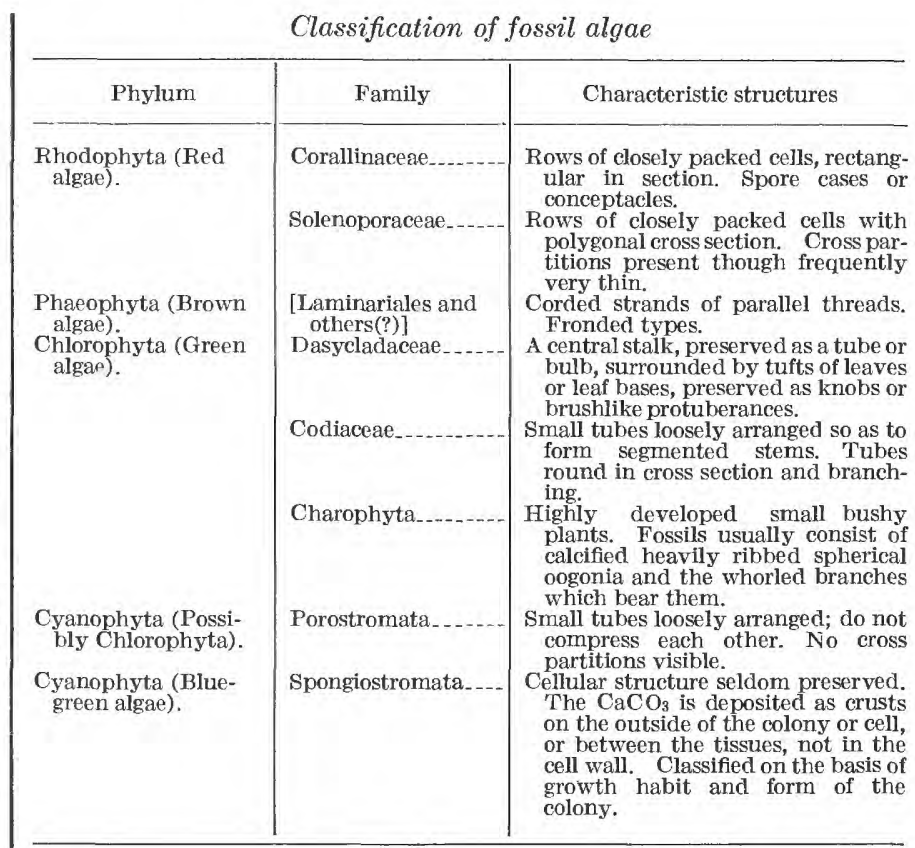

The calcareous green algae show varied degrees of calcification. Among the Dasycladaceae, the lime is deposited around the tissue forming molds of the plants and plant segments. The calcareous deposit may be sufficiently thick to envelope the entire plant, or it may be so thin as merely to coat the main stem and the primary branches. In Halimeda, on the other hand, the tissue itself is calcified, the process starting at the outer surface and working inward. In some cases the entire tissue is calcified; in others, only the outer part.

The red coralline algae is a difficult group to classify; several different classifications have been formulated for it. The features commonly used are: (a) Growth form; (b) arrangement of cells and differentiation of tissue; (c) features of the conceptacles, such as their shape, size, and position of the distribution of sporangia within them and the number of roof pores; (d) amount of calcification; (e) similarities of struc-

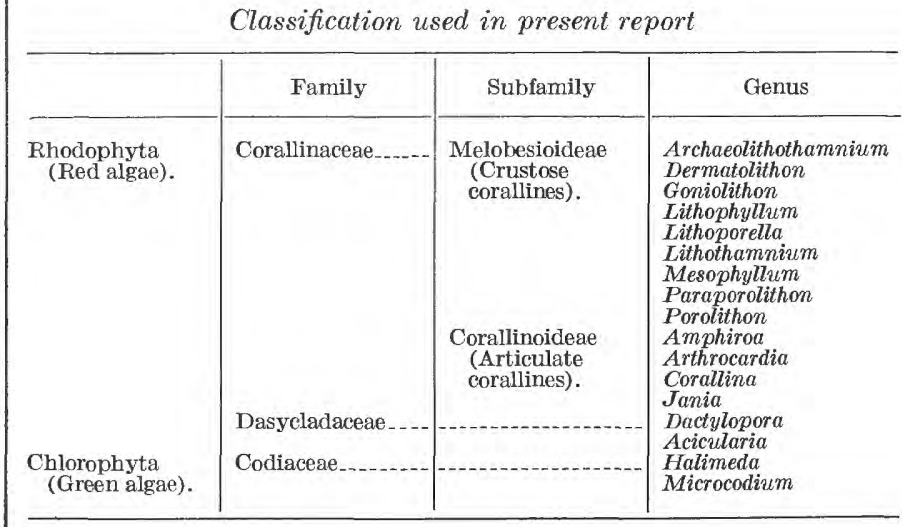


tures; and (f) assumed relationships and evolution. Foslie and other students of Recent algae have tended to emphasize features a and c, while Lemoine and others who have been interested primarily in fossil algae have emphasized $b$, c, and d. In recent years, several students have emphasized features e and $f$.

The paleobotanist who works with algae is handicapped because commonly he has only fragments of the plants, pieces of the branches, in most cases broken from the basal crust, or small parts of the crust. Many of the fragments are sterile. When remains of the conceptacles are present, the chamber may be compressed, filled with foreign material, or covered with scar tissue that gives little indication of the roof structure. Rarely do the conceptacles show traces of the sporangia or indications of their distribution.

Some workers have considered the amount of calcification as an important feature in classification but the writer discounts this, as a number of external factors, including the age of the plant, appear to be involved; old plants are commonly much more calcified than young ones.

The use of similarities of structures in classification is hazardous. In many instances such similarities do mean close relationship but they may be developed in unrelated stocks as a result of parallel evolution or as a response to living in a similar, rather specialized, environment.

Lemoine (1911) has shown that it is possible to divide the Recent genera of the crustose corallines into two groups based on the arrangement of the cells. In the first group, represented today by Lithothamnium, the basic structure is a row of cells usually growing nearly vertically. In the second group, the basic structure is a layer of cells spreading horizontally or roughly parallel to the outer surface of the plant. Other features commonly fit in with these two subdivisions. For example, almost all of the plants showing the first type of tissue structure have conceptacles whose roof is pierced by multiple pores, while practically all of those having the second type of tissue structure have conceptacles pierced by a single pore.

The group that causes the most trouble, both in preparing the classification and in identifying the individual fossils, consists of extremely thin forms having a crustose thallus that is formed of one or, at most, of only a few layers of cells. It is not surprising that in this group there has been confusion in the definition of genera. In many cases, it is impossible to refer a specimen to a given genus unless conceptacles are present. It is not known if the thin crustose forms represent an original simple structural type or are highly simplified descendants of ancestors that originally had a much more complex thallus.

The author agrees with Lemoine that the character of the basal hypothallus should be considered as a very important feature in classification. $\mathrm{He}$ is not so sure as to the value in classification of the medullary hypothallus of branching forms, as there seems to be a tendency among all highly branching forms to develop a medullary hypothallus. This is true among Lithothamnium, Lithophyllum, and Archaeolithothamnium. The medullary hypothallus is also a prominent structure among the articulated coralline algae, all of which are branching forms.

\section{KEYS TO THE TRIBES AND GENERA OF THE} CRUSTOSE CORALLINE ALGAE

[Genera marked with asterisk (*) were found in Eniwetok drill holes]

I. Sporangia collected into conceptacles............ III Sporangia not collected into conceptacles............ II

II. Tissue many layered with hypothallus and perithallusArchaeolithothamnium*

III. Conceptacles perforated by a few or many pores-Tribe Lithothamnieae_......................... IV

Conceptacles perforated by a single pore-Tribe Litho-

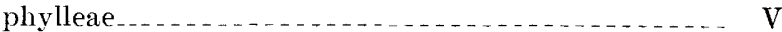

IV. Roof of sporangial conceptacles perforated by few to many pores-Tribe Lithothamnieae ................. 1

1. Thallus self-sustaining, not parasitic . . . _....... 2 2. IIypothallus a single layer of cells, at least in part; thallus epiphytic. Hypothallic cells in section, square or somewhat horizontally elongatedMelobesia

2. Hypothallus of many layers of cells;

3. Hypothallus of curved rows of cells _....... 3A

3. Hypothallus coaxial (arched rows or layers of cells)Mesophyllum*

3A. Sporangial conceptacles superficial or subimmersed-Lithothamnium*

3A. Sporangial conceptacles deeply immersed-Clathromorphum

V. Roof of sporangial conceptacles perforated by a single pore-Tribe Lithophylleae

1. Megacells present......................... 2A

1. Megacells absent ...................... 2B

2A. Hypothallus consists of a single layer of cells _. _ 3

3. Itypothallic cells vertically and obliquely elongated-Hydrolithon

3. Hypothallic cells square or nearly so-Fosliella

2A. Hypothallus of several to many layers of cells _. 3

3. Megacells in lenses or horizontal clusters-Porolithon *

3. Megacells singly or in vertical rows-Goniolithon *

3. Megacells in both horizontal and vertical clusters-Paraporolithon

2B. Hypothallus composed of cubic cells ......... 3

3. Thallus of several layers of cells-Heteroderma

3. Thallus of many layers of cells, not epiphytic-Lithophyllum *

$2 \mathrm{~B}$. Hypothallus of one or two layers of obliquely elongated cells.............................. 3 
V. Roof of sporangial conceptacles perforated by a single pore-Tribe Lithophylleae-Continued

2B. Hypothallus of one or two layers of obliquely elongated cells-Continued

3. Thallus characteristically epiphytic or epizoic commonly expanding locally to two or more layers with cells nearly equidimensional-Dermatolithon *

3 . Thallus prostrate, epiphytic, or epizoic often superimposed-single layered except immediately around conceptacles, cells vertically elongatedLithoporella*

\section{KEYS TO THE GENERA OF THE ARTICULATE CORALLINE ALGAE}

[Genera marked with asterisk $\left(^{*}\right)$ were found in Eniwetok drill holes]

I. Segments consist of several or many tiers of cells _ b. Segments consist of a single tier of long cellsLithotrix

II. a. Each tier composed of regular cells with straight

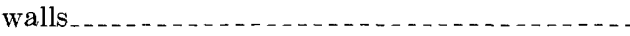

b. Tiers composed of irregular, sinuous and interlacing cells. (Conceptacles lateral. Nodes formed of a single tier of cells) - Calliarthron

III. a. Boundaries between tiers of cells essentially

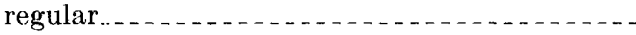

b. Boundaries between tiers of cells irregular, commonly more or less stepped. Cells commonly wedge shaped. Segments small, slender, cylindrical. Conceptacles terminal-Jania*

IV. a. Tiers of cells of principally the same length

b. Commonly there are tiers of long and short cells variously alternating. Segments show considerable variation in size and some variation in shape. Commonly they are cylindrical or flattened cylindrical. Nodes rather inconspicuous, of one or several tiers of cells. Conceptacles lateral-Amphiroa*

V. a. Tiers of cells gently but evenly arched ........

b. Tiers of cells flattened in central area, curving downward sometimes abruptly, toward the margins. Nodes of a single tier of cells. Branching regular, pinnate. Conceptacles are terminal-Arthrocardia*

VI. a. Segments not of same shape in different areas of the same plant

b. Segments cylindrical or flattened cylindrical. In section, commonly wider at top than at base. Notes conspicuous with a single tier of very long cells. Branching commonly in a plane, pinnate. Conceptacles terminal-Corallina*

VII. Segments commonly clavate, but may be oval, rounded, flattened or polygonal in section.

1. Biforcating branching. Conceptacles on margins of upper lobes of segments-Cheilosporum

2. Segments commonly cylindrical or nearly so near base of the frond becoming trapezoidal above. Branching pinnate. Conceptacles at the end of the lateral branches-Joculator

3 . Segments cylindrical or compressed cylindrical below, becoming flattened above with oval cross section. Branching dichotomous or alternating. Nodes consist of a single zone of cells. Conceptacles lateral-Bossea

\section{DISTRIBUTION AND ABUNDANCE}

The distribution of living calcareous algae is controlled, or at least strongly influenced, by a number of ecologic factors and, presumably, fossil species were similarly controlled. The most important factors are depth, salinity, temperature, intensity of light, turbidity, and, in the case of shallow-water forms, the character of the bottom. Each species adjusts itself to all of these factors.

The intensity of light seems to be the most important factor, with salinity ranking next. The depth range of a given species probably reflects the combined effects of light, salinity, agitation, and circulation. Experiments with some shallow-water forms have shown that they can tolerate a considerable variation in temperature and salinity for at least short times. Also, that they can stand abnormally high salinity better than a deficiency. Most of the coralline algae seem to require clear water, but some of the green algae are able to withstand appreciable amounts of mud or fine silt, although they too thrive best in clear water. The coralline algae commonly attach themselves to some hard substance, rock, coral, or fragments of hard organic debris, such as shells, fragments of coral, or other coralline algae. The green calcareous algae frequently spread over mud, lime mud, or even sandy bottoms.

\section{CRUSTOSE CORALIINE ALGAE}

The crustose coralline algae (subfamily Melobesioideae) are widely distributed both geographically and geologically. They are found in all the existing oceans, from the tropics to polar waters. Certain genera such as Archaeolithothamnium, Goniolithon, and Porolithon occur only in the tropical and warm temperate seas. Lithothamnium occurs in all seas but has its greatest development in the cold and cool temperate waters; Lithophyllum prefers the warmer waters, although some cool-water species are known.

Along rocky coasts in many places calcareous algae are found as thin white or pink crusts coating the rocks or forming shelves along the foreshore; they also occur in abundance immediately below low-tide level. Most branching forms develop in the zone between lowtide level and depths of 80 to 100 feet in the areas studied for this report; at greater depths the prevalent growth forms are crusts, which become smaller and thinner as the depths become greater. They are rare at depths below 400 feet, but specimens have been dredged from depths of 575 feet. 
Each of the littoral and sublittoral zones is characterized by certain species. Along the English Channel, for example, of the 14 species of crustose corallines observed, 5 were found only in the littoral zone, and 3 occurred only in the sublittoral, while 6 occurred in both zones. Species characteristic of the littoral zone do not occur at depth. Similarly, forms characteristic of deeper waters seldom occur close to the surface. Observations made by Taylor (1950), Weber van Bosse (1904), and Dawson (1944, 1952, 1954) show a similar ecological distribution in the tropics.

Many Recent genera of the Melobesioidaea may be traced to Late Cretaceous times. A few, such as Porolithon and Goniolithon, did not become abundant until the Pleistocene.

\section{ARTICULATE CORALLINE ALGAE}

The articulate corallines (subfamily Corallinoideae) also have a fossil record dating back to Cretaceous times. Today, they occur in the shallow waters of warm and temperate seas. Corallina and Jania are the only genera that occur in cool and temperate waters. Along the European coast, Corallina officinatis has been found as far north as 71 degrees (Lemoine, 1940, pl. 114). Amphiroa reaches as far north as the Mediterranean Sea and the Gulf of California. In tropical areas, Corallina and Jania occur with Amphiroa. The other genera are relatively rare and are restricted to warm waters.

Around Pacific coral reefs, articulate corallines have been collected at depths ranging from low-tide level to more than 100 feet but they are most common in shallow water. Tufts and patches of them may be found in pools in the reef flat or on the undersides of masses of coral or beach rock. Locally they may be abundant in the lagoons close to the reefs or island beaches.

Away from the reefs they also occur along rocky coasts. Some species grow in abundance attached to the rocks at about tide level in areas of strongly agitated water. Other species grow in rock pools immediately below the level of low tide.

\section{GREEN ALGAE}

Recent Dasycladaceae live in warm marine waters. They attain their greatest abundance and variety in the tropics but extend into warm temperate seas. They occur as far north as the Mediterranean coasts of France and southern Europe; on the eastern side of the Pacific, they occur on the California coast.
They are generally found in shallow marine waters, although they have been observed in bays and estuaries where the water is slightly brackish, and in a few lagoons where the water has a salinity higher than normal. Their range is approximately from low-tide level to depths approaching 250 feet, but they occur abundantly only in depths of less than 30 feet and especially in 10- to 15-foot depths (Lemoine, 1940, p. 124).

The writer has collected them on the reef flats around the island of Guam where at low tide they can be found on the underside of rocks or masses of coral in shallow tidal pools where they are sheltered both from the violence of the waves and from strong sunlight. A few were also found on the reef flats of Okinawa in similar surroundings; in 1 or 2 localities, sizeable patches were found growing on a sand bottom 15 to 18 feet below sea level. Taylor $(1950$, p. 49-50) described Neomeris which he found on the tops of loose coral fragments on the reef flats and to depths of 25 feet. $\mathrm{He}_{\mathrm{\theta}}$ also found a species of Acetabularia, which was obtained by divers at a depth of 30 feet.

Yamada (1934), in discussing the green algae of the Ryukyu Islands, described a number of species belonging to several genera from various places, all of which were found in tidal pools or at depths of a few meters.

Dasycladaceae commonly grow on sandy bottoms, on sandy clay bottoms, and on mud bottoms. They attach themselves to these relatively loose sediments with the aid of numerous fine hairlike growths. They also grow on loose pebbles, rock fragments, boulders, and on the underside of rocky masses and large corals in rock pools of the intertidal zone of reef flats and lagoons.

They range from Cambrian to Recent. Locally, from time to time they have been important limestone builders. They appear to have reached their zenith during the Late Triassic or Early Jurassic and to have been slowly declining since then. Dasycladacean limestone occurs abundantly in the Ordovician of Scandinavia, the Silurian of the Baltic region, the Permian of the southwestern United States, Japan, and the Adriatic region, and the Triassic of south-central Europe.

Halimeda is limited largely to the tropical and subtropical waters. It is common in the tropical Atlantic, tropical Pacific, and Indian Ocean, and is also found in the Mediterranean and in the Caribbean region. In the Pacific, it occurs as far south as $32^{\circ}$ on the west coast of Australia and in the Atlantic, to $34^{\circ}$ south on the east coast of South Africa. It extends northward 
in the western Pacific through the Ryukyu Islands and up to the southern coast of Japan. Specimens have been reported from numerous localities in Japan and even from Kamchatka. The Iatter appear to represent material carried north by the Japan current.

Specimens of fossil Halimeda have been reported from rocks as old as Late Cretaceous. They have been found in the Tertiary at many localities.

Species of Halimeda occur on both sandy and rocky bottoms and develop from areas exposed at low tides, down to depths more than 180 feet in the area studied for this report. Numerous species and forms have been described. They represent adaptations to a variety of environmental conditions. Some are found only in shallow water on sandy bottoms. Others grow attached to the rocks, particularIy in crevices and holes in the rocks; still others seem to develop best in the depressions and holes on the reef flat. The most Iuxuriant growths have been recorded in lagoons adjacent to reefs. Taylor, in his report on the plants of the Bikini area $(1950$, p. 76-93) gave considerable data on the ecological occurrences of Halimeda. He described 14 species and 11 forms of subspecies. Of these, only one was collected from the outer slope of the reef where it occurred at depths of 150 to 275 feet. Three occurred along the marginal zone of the reef in holes or crevices between corals or in the reef rock. Eight were common on the reef flat, and 18 occurred in the deeper waters of the lagoons, mainly, at depths of 120 to as much as 180 feet.

\section{ALGAE ON EXISTING REEFS}

Existing atolls normally consist of: $(a)$ An outer seaward slope, $(b)$ a marginal zone, $(c)$ a broad reef flat, and $(d)$ the lagoon. Each of these areas (Emery, Tracey, and Ladd, 1954) has a characteristic assemblage of algae.

The seaward slope.-Crustose coralline algae occur along the outer slope, abundantly at the top but in decreasing amounts with depth. Large colonies of branching forms are abundant near low-tide Ievel and are common to depths of 50 or 60 feet but are seldom found much deeper. In general, the colonies become smaller and the branches shorter and more widely spaced with depth. Thin encrusting forms are present at tide level but become more abundant with depth, with a maximum development at around 125 to 150 feet. At greater depths they become smaller, decrease in number, and have a darker color. Living specimens were dredged from depths as great as 1,100 feet at Bikini but they were small and scarce.

Locally, some articulated corallines develop on the upper parts of the reef slope, commonly at depths of from 10 to 50 feet, but they have been dredged from depths as great as 100 feet. Halimeda has about the same distribution as the articulated corallines.

The marginal zone.-Normally this is the area where the greatest development of calcareous algae occurs, culminating at times with the formation of the so-called Lithothamnium Ridge. This is probably the most spectacular development of coralline algae to be seen anywhere. Originally named the Nullipore Ridge by early writers, the term "Lithothamnium Ridge" is today somewhat a misnomer because the genus Lithothamnium has been broken up and, in the tropics, member's of the genus, as now recognized, have little to do with building the ridge. For example the welldeveloped ridge at Bikini is built almost entirely by a few species of Porolithon. The term "algal ridge" used by some authors would be more correct.

On the windward side of the reefs, waves beat with force and along the reef margin there is a development of rounded algal heads, usually compact colonies of highly branching forms, such as Porolithon gardineri. At normal low tide, the outer part of the reef margin may be exposed a foot or two above Iow-tide level, but is always kept moist by spray from the surf. This belt, normally, is rather narrow. At exceptionally low tides it may appear as a strip 40 to 50 feet wide, sometimes more, but frequently less. Behind this ridge, in the area of less agitated waters, the reef margin grades into a nearly smooth algal pavement composed of crustose nonbranching algae such as Porolithon onkodes. The algaI ridge may appear as a continuous strong outer reef margin or, if the surf is very heavy, it may be cut by numerous surge channels. Commonly, the calcareous algae are the only plants found along the algal ridge, but corals, mollusks, and echinoderms may be present in varying numbers particularly on the inner more protected areas.

The reef flat.-Behind the marginal zone, the reef flat normally extends toward the lagoon. In many places corals grow luxuriantly on the seaward part of the reef flat. Algae may grow with them, both crusts and small heads of branching types of the crustose corallines, tufts and clumps of articulated corallines, patches or tufts of Halimeda, and occasionally a few Dasycladaceae. In addition to these, noncaIcareous algae may be common, especially various types of green algae and occasionally some brown or red algae may be present. In some places, where there is a wide reef flat along the shores of islands, wide stretches or patches of the otherwise barren inner reef flat may be covered with brown algae.

The lagoon.-This is another area where algae may be abundantly developed. In areas between islands 
the reef flat slopes gently into the lagoon. Commonly at depths of more than 10 to 25 feet the bottom may be carpeted with both calcareous and noncalcareous algae. Among the former, Halimeda may be abundant even down to depths of 150 to 175 feet. In such areas Halimeda segments are the main constituent of the deposits on the lagoon floor. Chapman (1901, p. 163164) made an analysis of the organic content of 18 samples dredged at half-mile intervals across the Funafuti lagoon. Fifteen of these were at depths of 151/2 to 26 fathoms and the percentage of Hatimeda ranged from 75 to 99 . In the final report on the Funafuti expeditions Halligan (1904, p. 160-164) reported on two holes drilled in the lagoon floor. The Halimedarich sediment that covered the bottom was found to continue virtually unchanged for a thickness of 70 feet or more. In 1955, V. J. Chapman discussed Recent Funafuti algae.

Along the shores of islands and in the shallower margins of the lagoons, besides Halimeda, tufts of articulated corallines and small crustose corallines occur. Dasycladeceae may be found growing under other algae and on corals in the shallow waters and more rarely may develop into sizable patches at depths of from 10 to 35 feet, especially on areas of fine sediment.

\section{ALGAE IN DRILL HOLES}

In all the samples studied coralline algae were abundant in the Recent and Pleistocene(?) deposits; Halimeda was also present, at some places in abundance. In the Miocene and Eocene deposits algae occur in considerable abundance but they are not uniformly distributed. At some levels they are common, at others rare or entirely absent. Data on the distribution of algae in the various drill holes are given in the section, "Geographic distribution and stratigraphic occurrences of algae" at the end of this report. Many of the gaps represent parts of the section from which neither cores nor cuttings were recovered. A discussion of drilling and recovery is given by Ladd and others (1953) and by Ladd and Schlanger (1960).

\section{ALGAE AS LIMESTONE BUILDERS}

Studies of the samples obtained from the Funafuti drill hole (Royal Society of London, 190t) showed that calcareous algae were present from the surface to the bottom of the hole at 1,114 feet and that at many horizons they contributed notably to the bulk of the reef. Recent studies in the Marshall Islands and in the Mariana Islands have shown that algae play a vital role in building the framework of the reef (Emery, Tracey, and Ladd, 1954; Johnson, 1954b, 1957). The drill samples from Eniwetok, Funafuti, and Kita-Daitō-
Jima indicate that during much of Cenozoic time algae ranked next to Foraminifera in the rolume of the material contributed to the reef. Only locally and temporarily were the corals as important as the algae in reef construction. Among the limestones studied, the percentage of algae by volume ranges from a low of 3 percent to a high of about 48 percent and arerages about 17 percent. The crustose coralline algae and Halimeda are the important contributors with minor amounts of articulated corallines. A few Dasycladaceae were seen in the Eniwetok and Kita-Daitō-Jima drill samples, but were too rare to be of real importance as rock builders in these areas.

Today a number of species of Halimeda occur abundantly on and around the reefs, especially in the lagoons, and locally contribute considerably to the limestones. Some of the slides and specimens studied show that certain beds penetrated by the drill at Funafuti and Eniwetok were truly Halimeda limestones. These were quite common at Funafuti, occurring at intervals throughout the depth of the boring. They are not so abundant at Eniwetok but were especially well developed in the post-Tertiary beds.

In reef building, the coralline algae are the most important group. They assist in the formation of reefs in three ways: (a) By growing abundantly along the margin of the reef, particularly where the surf is strong, to form an algal ridge which breaks the force of the waves and protects the reef from erosion; (b) by acting as a binder to cement coral heads and fragments of other organisms into a more or less compact mass; and (c) by contributing to the volume of the reef mass. Taylor $(1950$, p. 28-30) gave a vivid description of the algal ridge at Bikini. Emery, Tracey, and Ladd (1954) and Johnson (1954 a, b) also discussed this feature and the importance of the work of the algae in reef construction.

\section{ALGAE AS INDICATORS OF AGE}

Studies made by Pia $(1926,1927)$ and by Mme. Lemoine (1939) in southern Europe and in the regions around the Mediterranean Sea showed that algae have considerable value as index fossils. Mme. Lemoine's work in Algeria revealed that the algal floras of each Epoch are quite distinct. Only a few Cretaceous species continue into the Eocene, whereas the Miocene floras are distinctly different from those of the Eocene and the Oligocene. Lemoine concluded that algal species have value in correlation as far as periods or epochs are concerned, but only in local areas can they be used for detailed stratigraphic correlation. She folnd, for example, that a species which occurs in the lower Eocene of Spain may occur in the middle Eocene 
in Libya or Morocco and be found even in the upper Eocene in Egypt or Persia, but very rarely does it extend into the Oligocene. The Mediterranean region is the only area in which sufficient work has been done on fossil algae to give us a knowledge of their time range. Until such work has been done in many other areas, the value of algae in correlation will be limited. The current studies of the geology of the Pacific Islands offer an opportunity to accumulate data for this purpose. Algae occur abundantly associated with Foraminifera whose time range is accurately known; consequently, the algae found in the various limestones can be dated with some assurance.

When studies of the algae and Foraminifera have been made from a larger number of islands, it will be possible to prepare a comprehensive chart showing the time range of the algal species in the Pacific region. A chart of this type presenting the data now available is given at the end of this paper. It will be noted that most of the species do not have a long time range.

\section{ALGAE AS ECOLOGICAL INDICATORS}

The algae can also be useful in interpreting the environment of deposition. Ecological studies in areas of the present seas have shown that the crustose types of coralline algae are found in abundance from the intertidal zone down to a depth of about 330 feet, and they occur sparingly to even greater depths. Those forming thin crusts or sheetlike masses seem to range from tide level down to the limit of light penetration, whereas those types that develop as masses of long branches seldom occur at depths greater than 30 feet. Articulated corallines grow from tide level to depths not exceeding 250 feet but do not appear to develop abundantly in depths greater than 75 feet. Algal distribution is affected not only by depth but by such factors as light, agitation of water, character of the bottom, the presence or absence of sediment, and the salinity of the water. The relation of these factors to the distribution of modern lime-secreting algae has been studied by a number of botanists, and the results were ably summarized by Lemoine in her 1940 paper and in a paper by Maxwell Doty on rocky intertidal surfaces (1957). Data on present-day distribution of many forms in the Marshall Islands are given by Taylor (1950) and Dawson (1957). Additional information on distribution is given under the generic descriptions in this paper.

Similar studies have been made regarding the distribution of the green algae. Halimeda thrives best in relatively shallow waters, from about tide level down to depths of about 50 or 60 feet, although specimens of some species have been found growing at depths of more than 250 feet. Luxuriant "Halimeda meadows" have developed over considerable areas of lagoon bottom at Bikini and Eniwetok. The author has observed similar derelopments in the shallow lagoon northwest of Peliliu in the Palau Islands, and over smaller areas at Ulithi Atoll and around Guam.

Pia (1927) has shown that the presence of abundant remains of Dasycladaceae always indicates shallow water and usually a muddy or silty bottom. In the present seas they are most abuudant in depths down to 30 feet. They are rarely found at depths below 50 feet.

\section{SYSTEMATIC DESCRIPTIONS}

Phyllum RHODOPHYTA (RED ALGAE)
Class RHODOPHYCEAE
Order CRYPTONEMIALES
Family CORALLINACEAE (coralline algae)
Subfamily MELOBESIOIDEAE (crustose corallines)

Description.-Characteristically strongly calcified, showing a great variety of growth forms. Some are monostromatic, others form crusts more than a centimeter thick. Crusts may be smooth, covered by protuberances, or branched. Some species develop loose branches or aggregates of branches.

A key to the tribes and genera was given earlier in the section on "Classification."

\section{Genus ARCHAEOLITHOTHAMNIUM Rothpletz, 1891}

Description.-Hypothallus consists of rows of cells that start horizontally, then curve upward into perithallus. Normally in perithallus vertical (transverse) cell rows more prominent than horizontal (longitudinal) layers. In some species growth zones may be distinguished. Most characteristic feature of genus found in the sporangia, which are not collected into conceptacles but occur in lenses or layers in tissue. They may be packed closely together, or may be separated from one another by thin segments of tissue.

Today the genus is restricted to warm marine waters, with a known depth range of from 1 to 130 feet. It appears to be most common in depths from 25 to 65 feet. Archaeolithothamnium has a geologic range from the Early Cretaceous to Recent. It reached its greatest development during the Eocene.

For convenience in classification species are grouped into three divisions based on the growth form of the plant. The following table shows dimensions and distribution of species.

Nineteen forms recognized, three of these being new. 
Measurements (in microns) and distribution of species of Archaeolithothamnium

\begin{tabular}{|c|c|c|c|c|c|c|c|c|c|}
\hline \multirow{2}{*}{ Species } & \multicolumn{2}{|c|}{ Hypothallus cells } & \multicolumn{2}{|c|}{ Perithallus cells } & \multicolumn{2}{|c|}{ Sporangia } & \multirow{2}{*}{ Locality } & \multirow{2}{*}{ Depth (feet) } & \multirow{2}{*}{ Age } \\
\hline & Length & Width & Length & Width & Height & Diameter & & & \\
\hline \multicolumn{10}{|c|}{ Division 1.--Simple crusts } \\
\hline $\begin{array}{l}\text { lauense Johnson and Ferris } \\
\text { marshrallensum Johnson n, sp } \\
\text { eniwetokensis Johnson n, sp } \\
\text { oulianovi Pfender } \\
\text { puntiense Airoldi....... } \\
\text { schmidti Foslie. } \\
\text { cf. A. sociabile Lemoine } \\
\text { cf. A. taiwanensis Ishijima. } \\
\text { sp. A }\end{array}$ & $\begin{array}{r}12-20 \\
9-19 \\
15-28 \\
9-21 \\
5-8 \\
7-10 \\
\\
15-23 \\
11-15 \\
7-12\end{array}$ & $\begin{array}{r}12-13 \\
7-11 \\
10-15 \\
8-12 \\
10-14 \\
7-11 \\
8-15 \\
6-9 \\
7-8\end{array}$ & $\begin{array}{r}12-15 \\
8-13 \\
14-18 \\
9-12 \\
8-14 \\
9-11 \\
\\
10-15 \\
11-13 \\
7-11\end{array}$ & $\begin{array}{r}10-13 \\
6-13 \\
10-13 \\
7-10 \\
7-12 \\
5-10 \\
\\
8-12 \\
7-11 \\
6-8\end{array}$ & $\begin{array}{c}141-195 \\
76-96 \\
41-50 \\
56-76 \\
62-96 \\
37-73 \\
\\
100-126 \\
75 \\
48-60\end{array}$ & $\begin{array}{l}41-50 \\
\\
75-100 \\
44-63 \\
25-30 \\
32-49 \\
30-59 \\
46-70 \\
\\
58-69 \\
50 \\
30-36\end{array}$ & 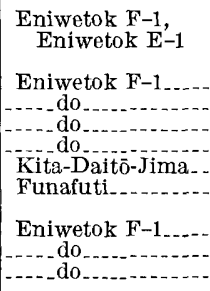 & $\begin{array}{r}12,000 \\
2,662-2,681 \\
1,718-1,740 \\
2,675 \pm \\
1,725-1,995 \\
1,978-2,003 \\
3,655-3,988 \\
51-513 \\
691-698 \\
\\
4,528-4,553 \\
1,718-1,740 \\
4,528-4,553\end{array}$ & $\begin{array}{c}\text { Miocene. } \\
\\
\text { Do. } \\
\text { Do. } \\
\text { Do. } \\
\text { Eocene. } \\
\text { Pleistocene (?) } \\
\text { Pleistocene or } \\
\text { Recent. } \\
\text { Eocene. } \\
\text { Miocene. } \\
\text { Eocene. }\end{array}$ \\
\hline \multicolumn{10}{|c|}{ Division 2.-Crusts with warty protuberances, mammillae, or short stubby branches } \\
\hline $\begin{array}{l}\text { Archaeolithothamnium erythraeum (Rothpletz) } \\
\text { Foslie. } \\
\text { cf. A. erythraeum (Rothpletz) Foslie } \\
\text { aff. A. erythraeum (Rothpletz) Foslie. } \\
\text { aff. A. saipanense Johnson, } \\
\text { nummuliticum (Gümbel) Rothpletz. } \\
\text { cf. A. hemchandri Rao. } \\
\text { sp. B. }\end{array}$ & $\begin{array}{l}10-40 \\
12-40 \\
\end{array}$ & $\begin{array}{r}9-12 \\
10 \\
11-13 \\
-10 \\
-10\end{array}$ & $\begin{array}{r}14-20 \\
13-19 \\
12-16 \\
12-14 \\
13-23 \\
\\
11-19 \\
8-11\end{array}$ & $\begin{array}{l}8-10 \\
8-10 \\
8-12 \\
9-14 \\
9-14 \\
\\
8-12 \\
8-11\end{array}$ & $\begin{array}{c}75-90 \\
95-119 \\
63-86 \\
145-165 \\
100-131 \\
\\
48-65\end{array}$ & $\begin{array}{l}45-55 \\
70-90 \\
30-50 \\
96-100 \\
55-90 \\
43-45 \\
-\end{array}$ & $\begin{array}{l}\text { Funafuti } \\
\text { Eniwetok E-1 } \\
\text { Eniwetok F-1 } \\
\text { Eniwetok E-1. } \\
\text { Eniwetok F-1. } \\
\text { Eniwetok E-1. }\end{array}$ & $\begin{array}{r}748-899 \\
\\
867-\quad 874 \\
2,340-2,660 \\
4,528-4,553 \\
2,802-2,808 \\
3,655-3,665 \\
4,197-4,202 \\
3,655-3,665 \\
2,730-2,740\end{array}$ & $\begin{array}{l}\text { Pleistocene or } \\
\text { Recent. } \\
\text { Pleistocene. } \\
\text { Miocene. } \\
\text { Eocene. } \\
\text { Do. } \\
\text { Do. } \\
\text { Do. } \\
\text { Do. } \\
\text { Do. }\end{array}$ \\
\hline \multicolumn{10}{|c|}{ Division 3.-Strongly branching forms } \\
\hline $\begin{array}{l}\text { Archaeolithothamnium aff. A. affine Howe........ } \\
\text { dallonii Lemoine. }\end{array}$ & $16-27$ & $11-14$ & $\begin{array}{l}11-16 \\
20-24\end{array}$ & $\begin{array}{l}9-10 \\
9-12\end{array}$ & $\begin{array}{l}90-120 \\
90-136\end{array}$ & $\begin{array}{l}34-36 \\
54-75\end{array}$ & Eniwetok E-1.... & $\begin{array}{l}2,350-2,360 \\
2,802-2,808\end{array}$ & $\begin{array}{l}\text { Miocene. } \\
\text { Eocene. }\end{array}$ \\
\hline
\end{tabular}

Division 1-Simple crusts

Archaeolithothamnium crustatum Johnson, n. sp.

Plate 267, figures 1, 2

Description.-Thallus thin, crustose, frequently growing superimposed. Hypothallus $0.5-1.3 \mathrm{~mm}$ thick, composed of few layers of slightly curved nearly horizontal rows of cells $15 \mu-23 \mu \quad(27 \mu)$ long and $9 \mu-13 \mu$ wide. Perithallic tissue quite regular, with well-defined transverse cell rows and fairly well marked longitudinal layers. Cells $11 \mu-19 \mu$ long and $9_{\mu-12 \mu}$ wide. Sporangia long, ovoid, measuring $85 \mu-$ $115 \mu$ high and $41 \mu-50 \mu$ in diameter.

Remarks.-This form resembles Archaeolithothamnium intermedium Raineri but has larger sporangia and more regular perithallic tissue without alternations of layers of cells of different length. It is close to the Eocene species from Eniwetok, $A$. c.f. sociabile Lemoine, in growth habit and cell size but has smaller and narrower sporangia and wider cells.

Age: Miocene.

Locality: Eniwetok F-1, depths 2,000 ft (core), 2,662-2,687 ft (core) ; E-1, 1,718-1,740 ft (cuttings).

Figured specimens: Holotype USNM 51424, 51425.
Archaeolithothamnium lauense Johnson and Ferris

Plate 267, figure 8

Archacolithothamnion Tauensum Johnson and Ferris, 1950, B. P. Bishop Mus. Bull. 201, p. 11, pl. 1, figs. A, D. Archaeolithothamnium lauense Johnson and Ferris. Johnson, 1957, U.S. Geol. Survey Prof. Paper 280-E, p. 218, pl. 46, fig. 7 .

Description.-Thallus irregular crust as much as 15 $\mathrm{mm}$ thick. Hypothallus poorly developed consisting of few curved rows of cells that attain length of $20 \mu$ and width of $12 \mu-13 \mu$. Perithallus forms compact tissue composed of well-defined vertical rows of cells with thin cross partitions. Cells $12 \mu-15 \mu$ by $10 \mu-13 \mu$. Sporangia abundant, ovoid or elliptical, large, measuring $141 \mu-195 \mu$ high and $75 \mu-100 \mu$ in diameter.

Remarks.-In appearance, structure, and dimensions of cells and sporangia, the Eniwetok specimens agree with the type although they developed a slightly thicker crust.

\section{Age: Miocene.}

Locality: Eniwetok F-1, depth about 2,675 ft (core).

Figured specimen: M-5, USNMI 51426.

\section{Archaeolithothamnium marshallensum Johnson n. sp.}

Plate 267, figure 5; plate 269 , figure 3

Description.-Thallus crustose, normally thin. Hypothallus 1-1.3 $\mathrm{mm}$ thick composed of horizontal to 
curved rows of cells $9 \mu-19 \mu$ long and $7 \mu-11 \mu$ wide. Perithallic tissue fairly regular, transverse cell rows slightly more conspicuous than horizontal cells which are $8 \mu-13 \mu$ long and $6 \mu-13 \mu$ wide. Sporangia ovoid, $76 \mu-96 \mu$ high and $44 \mu-63 \mu$ wide.

Remarks.-In cell dimensions and size of sporangia this form closely resembles A. kuboiensis Ishijima, but differs in having regular instead of contorted perithallic tissue, and in shape and arrangement of sporangia.

Age: Miocene.

Locality: Eniwetok F-1, depth 1,725-1,995 ft (core).

Figured specimens: F-1-5-1, holotype USNM 51427; F-1-535 , USNM 51428.

\section{Archaeolithothamnium eniwetokensis Johnson n. sp.}

Plate 267 , figure 6 ; plate 268 , figure 1

Description.-Thallus thin, crustose, surface irregular. Hypothallus $100 \mu-135 \mu$ thick consisting of curved rows of rectangular cells $15 \mu-28 \mu$ long and $10 \mu-15 \mu$ wide. Perithallic tissue fairly regular. Vertical cell rows slightly more pronounced than horizontal, but cells so regularly arranged as to produce nearly reticulate pattern in vertical section. Cells $14 \mu-18 \mu$ by $10 \mu-$ $13 \mu$. Sporangia small, round ovoid, $41 \mu-51 \mu$ high and $25 \mu-30 \mu$ in diameter.

Remarks.-This species has smallest sporangia of any Miocene species yet described. In cell dimensions and size of sporangia it suggests A. chamorrosum Johnson from the Eocene of Saipan but has much more rounded sporangia and more regular perithallic tissue.

Age: Miocene.

Locality: Eniwetok F-1, depth 1,978-2,003 ft (core).

Figured specimens: Holotype USNM 51429 (large); USNM 51430 (large).

\section{Archaeolithothamnium oulianovi Pfender}

Archaeolithothamnion outianovi Pfender, 1926, Soc. española historia nat. Bol., v. 26, p. 325, pl. 10.

Johnson. 1957. C.S. Geol. Survey Prof. Paper 280-E, p. 218, pl. 38, fig. 5 ; pl. 39, figs. 4.5 .

Description.-Very thin crusts which may grow superimposed. Tissue irregular. Hypothallus poorly developed $(50 \mu-90 \mu$ thick) consisting of few layers of irregular cells. Basal-layer cells commonly oblique. Cells measure $9 \mu-21 \mu$ by $8 \mu-12 \mu$. Perithallus rather irregular. Cells in well-defined vertical rows but not regular horizontally. Cells $9_{\mu-12 \mu}$ by $7 \mu-10 \mu$. Sporangia oval to circular in section, $56 \mu-76 \mu$ by $32 \mu-49 \mu$, occurring in isolated clusters.

Remarks.-Distinctive features of this species are irregular perithallic tissue more suggestive of Lithothamnium than normal Archaeolithamnium and irregular arrangement of sporangia. Cell s similar to those of type but show less range in size. They are simi- lar to the material attributed to this species from Eocene of Saipan.

Age: Late Eocene.

Locality: Eniwetok F-1, depth 3,655-3,988 ft (core).

specimens: F-1-9-9, F-1-10-1.

\section{Archaeolithothamnium puntiense Airoldi}

Archaeolithothamnion puntiense Airoldi, 1933, Palaeontographia Italica, Iem. Palaeont., v. 33, (new ser., v. 3), p. 83, pl. 7 , fig. 1 .

Johnson, 1957, U.S. Geol. Survey Prof. Paper 280-E, p. 218, pl. 53, figs. 3,4 .

Description.-Thallus irregular crusts from $0.5-15$ $\mathrm{mm}$ thick. Hypothallus thin (0.03-0.1 mm thick), containing only a few curved layers of cells measuring $5 \mu-8 \mu$ by $10 \mu-14 \mu$. Perithallus consists of fairly regular rows of cells, vertical partitions more conspicuous than horizontal. Cells rectangular, $8 \mu-14 \mu$ by $7 \mu-12 \mu$. Suggestions of thin irregular growth zones. Sporangia abundant in well-defined layers, majority oval in section, some subquadrate with rounded corners. Sporangial cavities measure $62 \mu-96 \mu$ high and $30 \mu-59 \mu$ wide. One specimen shows slightly larger sporangia, $80 \mu-130 \mu$ high and $66 \mu-72 \mu$ wide.

Remarks.-In growth habit and dimensions of cells and sporangia, Kita-Daitö-Jima material closely resembles Airoldi's type material from Pleistocene of Somaliland. Ishijima's species Archaeolithothamnium megamiensis from Tertiary of Japan (Ishijima, 1933, p. 29) probably represents same species. Both papers were published about the same time (1933). Unfortunately, Ishijima's description was brief and generalized, being based on single fragment. It would be preferable to tie Kita-Daitō-Jima species with Japanese material because of its geographic proximity, but Airoldi's species has a more solid basis than Ishijima's; so his name is applied. Cell dimensions and size of sporangia mainly same as Recent $A$. sibogae Weber van Bosse and Foslie (1904, p. 41-42), but they differ greatly in structure and growth habit. $A$. puntiense develops as thin crust, whereas $A$. sibogae forms a cluster of thick branches with tissue differentiated into medial hypothallus and perithallus.

Age: Pleistocene (?).

Locality: Kita-Daitō-Jima, depth $16 \mathrm{ft}(4.8 \mathrm{~m})$ and $160 \mathrm{ft}$ $(48.7 \mathrm{~m})$.

Specimens: Tōhoku University colln., slides 53 and 246.

Archaeolithothamnium schmidti Foslie

Archaeolithothamnion schmidti Foslie, 1901, Bot. Tidsskr., v. 24, p. 16

Weber van Bosse and Foslie, 1904, Siboga-Expeditie Mon. 61 , p. 43, pl. 8, figs. 16-17

Description.-Thallus develops thin irregular crust, which forms rounded nodular mass $0.3-0.7 \mathrm{~mm}$ thick. 
Hypothallus thin, composed of slightly curved rows of rectangular cells, many nearly square. Dimensions: $7 \mu-10 \mu$ long and $7 \mu-11 \mu$ wide (average $9 \mu$ by $8 \mu$ ). Perithallus formed of fairly regular rows of cells; horizontal partitions of tissue much stronger than vertical. Cells $9 \mu-10.5 \mu$ long and $5 \mu-10 \mu$ wide (average $10 \mu$ by $8.5 \mu$ ).

Sporangia circular to subelliptical; widely spaced in rows in tissue; size variable as shown by following dimensions in microns.

$$
\begin{array}{lll|lll}
45 & \text { by } & 52 & 46 & \text { by } & 70 \\
48 & \text { by } & 78 & 52 & \text { by } & 64 \\
37 & \text { by } & 73 & 52 & \text { by } & 57
\end{array}
$$

Remarks.-Growth habit and cell dimensions fit closely descriptions of Recent A. schmidti Foslie from Indochina and East Indies, except that conceptacles of Funafuti specimens are slightly wider than in type.

Age: Pleistocene or Recent.

Locality: Funafuti, main boring, depth 691-698 ft.

Archaeolithothamnium cf. A. sociabile Lemoine

Plate 267, figures 3,4

Archaeolithothamnion sociabile Lemoine, 1939, Mat. Carte géol. de l'Algerie, ser. 1, Paléont. no. 9, p. 53, figs. 16, 17.

Description.-Plants crustose, thin, some growing superimposed to form irregular crusts. Hypothallus $0.5-2 \mathrm{~mm}$ thick, formed of curved rows of cells $15 \mu-23 \mu$ long and $8 \mu-15 \mu$ high. Perithallus quite regular, horizontal layers almost as distinct as vertical rows. Cells rectangular, $10 \mu-15 \mu$ long and $8 \mu-12 \mu$ wide. Sporangia long ovoid, $100 \mu-126 \mu$ high and $58 \mu-69 \mu$ in diameter, closely packed, forming lenses in tissue.

Remarks.-In appearance, growth habit, and cell dimensions Eniwetok form closely resembles $A$. sociabile described by Lemoine from Algeria but has slightly larger sporangia and a somewhat greater development of the hypothallus.

Age: Late Eocene.

Locality: Eniwetok F-1, depth 4,528-4,555 ft (core).

Figured specimens: F-1-15-4 ( 1 and 2), USNM 51431, 51432.

\section{Archaeolithothamnium cf. A. taiwanensis Ishijima}

Plate 267, figure 7

Archaeolithothamnion taiwanensis Ishijima, 1942. Taiwan Tigaku Kizi, v. 13, no. 4, p. 120 (2), fig. 2.

Ishijima, 1954, Cenozoic and coralline algae western Pacific, p. 18, pl. 1, fig. 5.

Johnson, 1957, U.S. Geol. Survey Prof. Paper 280-E, p. 218, pl. 46, figs. 4-6.

Description.-Thallus rounded. Hypothallus 1-1.5 mm thick of curved rows of cells $11 \mu-15 \mu$ long and $6 \mu-9 \mu$ wide. Perithallus fairly regular with cells $11 \mu-$ $13 \mu$ long and $7 \mu-11 \mu$ wide. Sporangia $72 \mu$ by $50 \mu$
Remarks.--Represented by single fragment in Eniwetok collections. Closely agrees with Ishijima's type from Formosa but has better developed hypothallus.

Age: Miocene.

Locality: Eniwetok F-1, depth 1,718-1,740 ft (core).

Figured specimen: $\mathrm{F}-1-4-8$ (1), USNM 51433.

\section{Archaeolithothamnium sp. A}

Plate 267, figure 9

Description.-Thallus a thin irregular crust. Hypothallus $100 \mu-150 \mu$ thick composed of curved rows of small cells measuring $7 \mu-12 \mu$ by $7 \mu-8 \mu$. Perithallus rather irregular, cells $7 \mu-11 \mu$ by $6 \mu-8 \mu$. Sporangia $48 \mu-60 \mu$ high and $30 \mu-36 \mu$ in diameter.

Remarks.-Represented by a single specimen. Suggests $A$. outianovi Pfender in growth habit and general character of tissue. Sporangia slightly smaller, cells smaller and square in section rather than oblong, as in A. oulianovi.

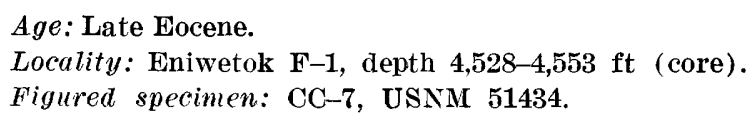

Division 2-Crusts with protuberances or short branches

Archaeolithothamnium erythraeum (Rothpletz) Foslie

Plate 268, figures 2, 3

Lithothamnium erythraeum Rothpletz, 1893, Bot. Centralbl., no. 14.

Archaeolithothamnion erythraeum Foslie, 1900, K. norske vidensk. selsk. Skr., no. 5, p. 8.

Weber van Bosse and Foslie, 1904, Siboga-Expeditie Mon. 61 , p. 38-41, pls. 5 and 6.

Description.-Thallus started as thin crust, then developed small mammillate protuberances. In 3 specimens in which thallus was observed, it measured 0.360 $\mathrm{mm}, 0.385 \mathrm{~mm}$, and $0.246 \mathrm{~mm}$ in thickness. Hypothallus poorly developed, consisting of only a few nearly horizontal rows of cells, rather irregular, square to rectangular, mostly long and narrow. Size range from $10 \mu-40 \mu$ long and $9 \mu-12 \mu$ wide. Perithallus forms most of crust, composed of quite regular rows of cells from $14 \mu-20 \mu$ long and $8 \mu-10 \mu$ wide. Occasionally, a row of shorter cells sandwiched between rows of longer cells. Shorter cells nearly square and average $6 \mu-9 \mu$ by $7 \mu-10 \mu$. Sporangia normally long and oval but some nearly spherical, others irregular. They measure $75 \mu-90 \mu$ by $45 \mu-55 \mu$.

Remarks.--Specimens studied badly recrystallized, and it was difficult to measure cells except in few local patches. General appearance, growth habits, and dimensions of cells and sporangia are same as in Recent specimens of this species from tropical Pacific. 
Age: Pleistocene or Recent.

Locality: Funafuti, slide 699, depth $748-763 \mathrm{ft}$; main boring, slide 703 , depth $764 \mathrm{ft}$; slide 773 , depth $891-899 \mathrm{ft}$.

Figured specimen: British Museum slide 773.

Archaeolithothamnium cf. A. erythraeum (Rothpletz) Foslie

Description.-Fragment of crust with mammilated surface about $0.5 \mathrm{~cm}$ thick. Hypothallus poorly developed. Exact measurement of cells impossible because of recrystallization, but they approximate $12 \mu-40 \mu$ by $10 \mu$. Perithallus thick, layers of short approximately square cells alternate with several layers of long cells. Cells approximate $13 \mu-19 \mu$ by $8 \mu-10 \mu$. Conceptacles elongate oval, in fairly regular rows in tissue; locally conceptacles are closely packed. Size $95 \mu-119 \mu$ by $70 \mu-90 \mu$.

Remarks.-Represented by one badly recrystallized specimen. General appearance, growth habit, and cell dimensions fit modern $A$. erythraeum, but conceptacles somewhat larger, more regular, and more closely spaced.

Age: Pleistocene.

Locality: Funafuti, main boring. British Museum slide 757, depth 867-874 ft.

\section{Archaeolithothamnium aff. A. erythraeum (Rothpletz) Foslie}

Plate 268 , figure 4

Archaeolithothamnion erythracum, Weber van Bosse and Foslie, 1904. Siboga Expeditie Mon. 61, p. 39, pls. 5, 6.

Description.-Thallus crustose with rounded knobs or short stubby branches. Hypothallus not observed. Perithallic tissue compact, locally rather irregular, but in most cases with cells in fairly regular rows and layers. Cells rectangular $12 \mu-16 \mu$ by $8 \mu-12 \mu$. Sporangia oval to almost cylindrical, $63 \mu-86 \mu$ by $30 \mu-50 \mu$.

Remarks.-Represented by only few fragments. Material strongly resembles Recent $A$. erythraeum, cells in same size range, but conceptacles of Eniwetok specimens smaller. Ishijima described a species from the 'Tertiary of Japan (1933, p. 29) as A. megamiensis that almost corresponds in dimensions with present species except for growth form. It also resembles $A$. taiwanensis Ishijima. Ishijima's description so generalized that comparison is difficult. His species, however, appear to have smaller cells and conceptacles.

Age: Miocene.

Locality: Eniwetok, from cuttings collected from $\mathrm{E}-1$ at depths of 2,340-2,660 ft but may have come from higher levels.

Figured specimen: $34, \mathrm{E}-1$, depth 2.650-2,660 ft, USNM 51435 .

\section{Archaeolithothamnium aff. A. saipanense Johnson}

Archacolithothamnium saipanense Johnson, 1957, U.S. Geol. Survey Prof. Paper, 280-E, p. 220 , pl. 38, figs. $1-4,6$.

Description.-Thallus crustose, possibly with protuberances. Hypothallus about $120 \mu$ thick. Cell rows
$11 \mu-13 \mu$ wide. Cell lengths could not be measured because of poor preservation. Perithallic tissue compact and fairly regular with cells $12 \mu-14 \mu$ by $9 \mu-14 \mu$. Sporangia large, ovoid, $145 \mu-165 \mu$ high and $96 \mu-100 \mu$ wide.

Remarks.-Represented by single specimen. It closely resembles $A$. saipanense Johnson in growth habit and cell size but has appreciably larger sporangia. Sporangia largest observed in any Eocene Archeolithothamnium. It may represent new species, but until more and better material is available, it does not seem desirable to give it a new name.

Age: Late Eocene.

Locality: Eniwetok F-1, depth 4,528-4,553 ft (core).

specimen: DD-5, USNM 51436.

Archaeolithothamnium nummuliticum (Gümbel) Rothpletz

Plate 268 , figure 6 ; plate 269 , figure 2

Lithothamnion nummuliticum Gümbel, 1861, Geognostische Beschreibung des bayerischen Alpengebirges und seines Vorlandes, p. 654 .

Gümbel, 1871, Abhand. d. K. bay. Ak. Wiss., II Klasse, v. 11, pt. 1, p. 27 , pl. 1, fig. 2 b.

(Gümbel) Rothpletz, 1891, Deutsche geol. Gesell. Zeitschr., v. 43 , p. 316 , pl. 17 , fig. 5 .

Capeder, 1900, Contrib. allo studio der Lithothamnium terziari, Malpighia, p. 176, pl. 6, fig. 2.

Archaeolithothamnion nummuliticum (Gümbel) Lemoine, 1917, Bull. géol. Soc. France, ser. 4, v. 17, p. 247.

Lemoine, 1927, Mus. nat. histoire nat. Bull. (Nov. 1927), p. 546, fig. 1.

Lemoine, 1934, Vestni. stat. Geolog. ustavu esl. rep., v. 9, no. 5 , p. 273.

Lemoine, 1939, Mat. carte géol, de l'Algerie, ser. 1, Paléont., no. 9 , p. 56 .

Description.--Thallus crustose, developing protuberances or even short stubby branches. Hypothallus absent on specimens studied. Perithallus composed of rectangular cells $13 \mu-23 \mu$ by $9 \mu-14 \mu$ (commonly $16 \mu-23 \mu$ by $9 \mu-12 \mu$ ). In some cases, tissue regularly arranged; in others irregular. In most areas vertical partitions more pronounced than horizontal. Sporangia large, ovoid to almost rectangular, measuring $100 \mu-$ $131 \mu$ by $55 \mu-90 \mu$.

Remarks.-Widely distributed species with long geological range. It has been described by many authors from western Europe, Mediterranean basin, and Near East. It is characterized by its unusual growth habit, relatively large rectangular perithallic cells, and large sporangia.

The several Eniwetok specimens have same growth habit, cell size, and length of sporangia. They differ in having somewhat wider sporangia (as much as $90 \mu$ instead of $65 \mu$ ) and more pronounced vertical cell rows than in specimens attributed to this species in Mediterranean region. 
Species suggests $A$. saipanense Jolnnson but has appreciably larger perithallic cells.

Age: Late Eocene.

Locality: Eniwetok E-1-2-3, depth, 2,802-2.808 ft (core) ; $\mathrm{F}-1,3,655-3,665 \mathrm{ft}$, and $4,197-4,222 \mathrm{ft}$ (cores).

Figured specimens: F-1-9-2 (4) (large), USNM 40813; E-1-2-3 (2) (large), USNM 40810.

Archaeolithothamnium of. A. hemchandri Rao

Plate 268, figure 7

Archaeolithothammion hemchandri Sripada Rao, 1943, Natl. Acad. Sci. India, Proc., v. 13, pt. 5, p. 275, pl. 1, fig. 7.

Description.-Thallus encrusted with mammiliform protuberances, hypothallus absent, perithallus of rectangular cells showing fairly pronounced recticulated pattern and measuring $11 \mu-19 \mu$ by $8 \mu-12 \mu$. Sporangia rounded ovoid $43 \mu-45 \mu$ by $48 \mu-65 \mu$.

Remarks.-Species represented by one specimen from Eniwetok material. It closely resembles type species described from lower Eocene of Assam but cells average larger and are slightly more irregularly arranged. A. hemehandi $i$ is distinguished from all other Eocene species of Archaeolithothamninm by its small cells and nearly spherical sporangia.

Age: Late Eocene.

Locality: Eniwetok F-1, depth 3,655-3,665 ft (core).

Figured specimen: F-1-9-2 (2) (large), USNM 51437.

\section{Archaeolithothamnium sp. B}

Description.-Plant with short stubby branches, tissue of branches formed of rows of small nearly cubic cells so regularly arranged that they appear to be in layers. Cell walls forming both vertical and horizontal partitions are thin but clearly defined. Cells measure $8 \mu-11 \mu$ by $8 \mu-11 \mu$. Conceptacles unknown.

Remarks.--Represented in Eniwetok collection by two worn fragments of branches.

Age: Late Eocene.

Locality: Eniwetok E-1, depth, 2,730-2,740 ft (cuttings).

Division 3-Strongly branching forms

Archaeolithothamnium aff. A. affine Howe

Plate 269, figure 1

Archaoelithothamnion affine Howe, 1919, Carnegie Inst. Washington Pub. 291, p. 11, pl. 4, fig. 1; pl. 5, figs. 1-2.

Lemoine, 1939, Mat. Carte géol. de l'Algerie, ser. 1, Paléont., no. 9 , p. 60, fig. 25 .

Lignac-Grutterink, 1943, Geol.-mijnb. genootsch. Nederland en Kolonien Verh., Geol. ser. jagu 113, p. 286, fig. 1.

Description.-Strongly branching form with distinct medullary hypothallus and marginal perithallus. Branches 2-3 $\mathrm{mm}$ in diameter. Medullary hypothallus forms most of branch; composed of curved layers of rectangular cells $16 \mu-27 \mu$ by $11 \mu-14 \mu$. There are sug- gestions of growth zones. In these zones transverse upward-growing cell rows more conspicuous than layers. Marginal perithallus is $2-3 \mathrm{~mm}$ thick, composed of cells $11 \mu-16 \mu$ by $9 \mu-10 \mu$.

Sporangia numerous, in regular rows in medullary hypothallus tissue; sporangia long and ovoid, some almost cylindrical; size $90 \mu-120 \mu$ by $34 \mu-36 \mu$. Sporangia, in most cases, separated from one another by a few rows of tissue cells.

Remarks.-Very few branching species of Archaeolithothamnium with well-developed medullary hypothallus have been reported from Miocene. This form from Eniwetok most closely resembles $A$. affine described by Howe from Oligocene of West Indies, but has appreciably longer sporangia and more sharply separated hypothallus and perithallus.

Lignac-Grutterink reported material under this name from East Indies, but the Eniwetok specimen has longer sporangia and much more distinct marginal perithallus.

Specimen closely resembles the Recent $A$. timorense of tropical Pacific but has more nearly quadrate cells and longer sporangia. It probably represents an undescribed species but, with only one fragment available for study, it does not seem wise to describe it as such.

Age: Miocene.

Locality: Eniwetok E-1, depth 2,350-2,360 ft (cuttings).

Figured specimen: E-1, 2,350-2,360 ft, USNM 51438.

Archaeolithothamnium dallonii Lemoine

Plate 268, figure 5

Age: Miocene.

Locality: Eniwetok E-1, depth 2,350-2,360 ft (cuttings).

Figured specimens: F-1-9-2 (4) (large), USNM 40813.

Description.-Strongly branching form. Perithallic tissue regular with well-defined horizontal and vertical partitions. Cells $20 \mu-24 \mu$ by $9 \mu-12 \mu$. Sporangia long oval to gourd shaped, $90 \mu-136 \mu$ by $54 \mu-75 \mu$.

Remarks.--Represented by single well-preserved fragment from Eniwetok which resembles very closely Mme. Lemoine's type material from western Mediterranean. Only difference is that some of sporangia attain a slightly greater length in Eniwetok specimen.

This species closely resembles $A$. nummuliticum (Gümbel) Rothpletz except in growth form (strongly branching versis a crust with short stubby branches) and in having smaller sporangia.

Age: Late Eocene.

Locality: Eniwetok E-1, depth 2,802-2,808 ft (core).

Figured specimen: E-1-2-9 (large), USNM 51439.

\section{Genus IITHOTHAMNIUM Philippi, 1837}

The thallus may be crustose or with erect branches growing from a basal crust. The tissue consists of a 
hypothallus and a perithallus. A thin epithallus is present in living plants; it may or may not be preserved in fossils. Commonly, the hypothallus consists of loosely spaced horizontal rows of elongated cells that branch and curve upward at right angles to the substratum. The perithallus is composed of vertical infrequently branched cell rows, with the cells quadrate, rectangular, or ovate. Sporangial conceptacles have many openings or pores in the roof for the escape of spores.

This genus is represented by a number of species in the samples from Eniwetok, Kita-Daitō-Jima, and Funafuti.

For convenience in study the species are grouped in three divisions based on the growth form:

Division 1.-Simple crusts.

Division 2.-Crusts with warty protuberances or short stubby branches.

Division 3.--Strongly branching forms.

The following table summarizes the characteristic features of each species of Lithothamnium described.

Measurements (in microns) and distribution of species of Lithothamnium

\begin{tabular}{|c|c|c|c|c|c|c|c|c|c|}
\hline \multirow{2}{*}{ Species } & \multicolumn{2}{|c|}{ Hypothallus cells } & \multicolumn{2}{|c|}{ Perithallus cells } & \multicolumn{2}{|c|}{ Conceptacles } & \multirow{2}{*}{ Locality } & \multirow{2}{*}{ Depth (feet) } & \multirow{2}{*}{ Age } \\
\hline & Length & Width & Length & Width & Diameter & Height & & & \\
\hline \multicolumn{10}{|c|}{ Division 1.-Simple crusts } \\
\hline \multicolumn{10}{|c|}{ [Commonly thin; several may be superimposed] } \\
\hline $\begin{array}{l}\text { Lithothamnium ef. L. abrardi Lemoine } \\
\text { crispithallus Johnson } \\
\text { cymbicrusta Johnson } \\
\text { leptum Johnson and Ferris } \\
\text { sp. A A } \\
\text { sp. B B } \\
\text { sp } \mathrm{C}\end{array}$ & $\begin{array}{r}16-26 \\
11-21(34) \\
15-27 \\
9-12 \\
14-23 \\
9-14 \\
22-42\end{array}$ & $\begin{array}{r}9-12 \\
8-13 \\
10-15 \\
8-12 \\
10-13 \\
9-12 \\
8-16\end{array}$ & $\begin{array}{r}12-15 \\
7-14 \\
10-15 \\
12-18 \\
12-13 \\
9-11 \\
8-19\end{array}$ & $\begin{array}{r}9-12 \\
6-11 \\
10-12 \\
9-12 \\
11-14 \\
10-14 \\
9-14\end{array}$ & $\begin{array}{r}550-590 \\
304-537 \\
235-405 \\
- \\
\hdashline\end{array}$ & $\begin{array}{r}190 \\
185-200 \\
115-153 \\
-\end{array}$ & \begin{tabular}{|l|} 
Eniwetok F-1 \\
do
\end{tabular} & $\begin{array}{l}4,528-4,553 \\
4,500-4,553 \\
4,528-4,553 \\
1,718-2,670 \\
1,978-2,003 \\
2,662-2,668 \\
1,740-2,670\end{array}$ & $\begin{array}{l}\text { Eocene. } \\
\text { Do. } \\
\text { Do. } \\
\text { Miocene. } \\
\text { Do. } \\
\text { Do. } \\
\text { Do. }\end{array}$ \\
\hline \multicolumn{10}{|c|}{ Division 2.-Crusts with warty protuberances or short stubby branches } \\
\hline $\begin{array}{l}\text { Lithothamnium aff. } L \text {. aucklandicum Foslie } \\
\text { funafutiense Foslie } \\
\text { cf. L. nitidum Foslie } \\
\text { cf. L. mirabile Conti }\end{array}$ & $\begin{array}{r}7-11 \\
10-24 \\
9-16 \\
14-30\end{array}$ & $\begin{array}{r}12-14 \\
10-12 \\
6-8 \\
8-13\end{array}$ & $\begin{array}{r}9-11 \\
6-14 \\
8-14 \\
12-18\end{array}$ & $\begin{array}{r}6-8 \\
6-11 \\
6-10 \\
8-16\end{array}$ & $\begin{array}{r}223-242 \\
500-750 \\
578-807 \\
-\end{array}$ & \begin{tabular}{r|r|}
$122-143$ \\
$275-298$ \\
-15
\end{tabular} & $\begin{array}{l}\text { Kita-Daitō-Jima.. } \\
\text { Funafuti.-...... } \\
\text { Kita-Daitō-Jima.. } \\
\text { Eniwetok F-1.... }\end{array}$ & $\begin{array}{r}0-173 \\
0-800 \\
0-16 \\
1,978-2,003\end{array}$ & $\begin{array}{l}\text { Pleistocene. } \\
\text { Recent and Pleistocene } \\
\text { Pleistocene. } \\
\text { Miocene. }\end{array}$ \\
\hline \multicolumn{10}{|c|}{ Division 3.-Strongly branching forms } \\
\hline Lithotha mnium sp. D... & $23-33$ & $14-18$ & $9-15$ & $13-16$ & & & Eniwetok E-1..... & $2,003-2,008$ & Miocene. \\
\hline
\end{tabular}

Division 1-Simple crusts

Lithothamnium of. I. abrardi Lemoine

Lithothamnium abrardi Lemoine, 1934, Czechoslovakia, Statni Geol. Ustav, Věstnik r. 9, c. 5, p. 274, fig. 3.

Lemoine, 1939, Mat. Carte géol. de l'Algerie, ser. 1, Paléont., no. 9 , p. 67 .

Lithothamnium cf. L. abrardi Lemoine. Johnson, 1957, U.S. Geol. Survey Prof. Paper 280-E, p. 221, pl. 41, figs. 6, 7 ; pl. 42 , figs. 1,5 .

Description.-Thallus thin crust with well-developed hypothallus and poorly to moderately developed perithallus. Hypothallus consists of curved rows of cells $16 \mu-26 \mu$ by $9 \mu-12 \mu$. Perithallus of rectangular cells $12 \mu-15 \mu$ by $9 \mu-12 \mu$. No conceptacles present.

Remarks.-In general appearance and in cell dimensions Eniwetok material agrees with specimens described under this name from Focene of Saipan.

Age: Late Eocene.

Locality: Eniwetok F-1, depth 4,528-4,553 ft (core).

Specimen: DD-2.

\section{Iithothamnium crispithallus Johnson}

Lithothamnium crispithallus Johnson, 1957, U.S. Geol. Survey Prof. Paper 280-E, p. 223, pl. 42, figs. 6-8.

Description.-Thallus thin curving crusts, apparently originally attached but later growing free. $\mathrm{Hy}$ pothallus well developed, $90 \mu-170 \mu$ thick, consisting of curved rows of cells $11 \mu-26 \mu(34 \mu)$ by $8 \mu-13 \mu$. Perithallus thin, irregular, thickening greatly around conceptacles; cells $7 \mu-14 \mu$ by $6 \mu-11 \mu$. Conceptacle chamber $550 \mu-590 \mu$ by $190 \mu$.

Remarks.-Represented by a number of specimens. The Eniwetok specimens have longer perithallic cells than those described from Saipan.

Age: Late Eocene.

Locality: Eniwetok F-1, depth 4,500-4,553 ft. (core).

Specimens: CC7 ; F-1-15-13 (2) large; F-1-15-3 (2) large F-1-14-29 large. 


\section{Lithothamnium cymbicrusta Johnson}

Lithothamnium cymbicrusta Johnson, 1957, U.S. Geol. Survey Prof. Paper 280-E, p. 224, pl. 40, figs. 1, 6, 7 ; pl. 41, fig. 8.

Description.-Thallus thin regular crust about $300 \mu$ thick. Hypothallus well developed, forming most of crust. Hypothallus composed of rows of cells with fanlike arrangement, curving from center toward top and bottom; cells $15 \mu-27 \mu$ by $10 \mu-15 \mu$. Perithallus thin, composed of regular rows of nearly square cells $10 \mu-15 \mu$ by $10 \mu-12 \mu$. Clusters of conceptacles occur in little knobs raised above general level of crust. Conceptacle chambers $304 \mu-537 \mu$ by $185 \mu-200 \mu$.

Remarks.-Eniwetok specimens agree with material described from Saipan except for larger size of some conceptacles. The large fanlike hypothallus and knobs of conceptacles seem to be very characteristic features of the species.

Age: Late Eocene.

Locality: Eniwetok F-1, depth 4,528-4,553 ft (core).

specimen: DD-2.

\section{Lithothamnium leptum Johnson and Ferris}

Plate 270, figure 7

Lithothamnion leptum Johnson and Ferris, 1950, B. P. Bishop Mus. Bull. 201, p. 13, pl. 2, fig. D.

Description.--Thallus thin irregular crust. Numerous thalli may grow superimposed to form an irregular mass. Hypothallus poorly developed or absent, at most only few rows of cells that measure $9 \mu-12 \mu$ by $8 \mu-12 \mu(14 \mu)$. Perithallus consists of rows of rectangular cells $12 \mu-18 \mu$ by $9 \mu-12 \mu$. Conceptacle chambers $235 \mu-405 \mu$ by $115 \mu-153 \mu$.

Remarks.--Eniwetok specimens closely agree with type material from Lau, Fiji. Also close to $L$. araii Ishijima from the Miocene of Japan.

Age: Miocene.

Locality: Eniwetok F-1 depths 1,718-2,670 ft (cores).

Figured specimen: F-1-6-12, USNM 40799.

\section{Lithothamnium sp. A}

Plate 269, figure 8

Description.-Thallus a thin irregular crust $200 \mu-$ $350 \mu$ thick. Hypothallus plumose, $100 \mu-125 \mu$ thick; rectangular cells $14 \mu-23 \mu$ by $10 \mu-13 \mu$. Perithallus $100 \mu-200 \mu$ thick; shows irregular growth zones of rows of rectangular cells $12 \mu-13 \mu$ by $11 \mu-14 \mu$. Conceptacles unknown.

Remarks.-Form has about the same dimensions as L. bikiniensum Johnson from lower Miocene of Bikini but has well-developed rather plumy hypothallus and thicker crusts. Without knowledge of conceptacles of either species, they are considered as closely related but probably different.
Age: Miocene.

Locality: Eniwetok F-1, depth 1,978-2,003 ft (core).

Figured specimen: F-1-5-12 (3), USNM 40800.

\section{Lithothamnium sp. B}

Plate 270, figure 2

Description.-Thallus an irregular crust $300 \mu-500 \mu$ thick. Hypothallus plumose, $175 \mu-200 \mu$ thick with local fanlike developments. Cells $9_{\mu-14 \mu}$ by $9_{\mu-12 \mu}$. Perithallus relatively thin; cells $9 \mu-11 \mu$ by $10 \mu-14 \mu$. Conceptacles unknown.

Remarks.-Species closely related to $L$. araii Ishijima and L. leptum Johnson and Ferris but has welldeveloped plumy hypothallus.

Age: Miocene.

Locality: Eniwetok F-1, depth 2,662-2,668 ft. (core).

Figured specimen: F-1-6-28 (3), USNMI 40801.

\section{Lithothamnium sp. C}

Plate 269, figures 6, 7

Description.-Thallus an irregular crust $0.600-$ $0.750 \mathrm{~mm}$ thick; well-developed hypothallus and perithallus. Hypothallus $150 \mu-250 \mu$ thick, composed of curved rows of cells $22 \mu-42 \mu$ by $8 \mu-16 \mu$. Perithallus somewhat irregular, with noticeable growth zones; cells $8 \mu-19 \mu$ by $9 \mu-14 \mu$. Conceptacles unknown.

Remarks.-This species differs from any previously described Miocene Lithothamnium in having unusually long hypothallic cells. Only L. lauense Johnson and Ferris has longer cells, but it has a poorly developed hypothallus in contrast to the thick conspicuous hypothallus of sp. C. Without a knowledge of the conceptacles, it does not seem desirable to give it a specific name.

Age: Miocene.

Locality: Eniwetok F-1, depth 1,740-2,670 ft (cores) .

Figured specimens: F-1-4-19 (1) large, USNM 40802; F-1-6-23 (4) large, USNM 40803.

Division 2-Crusts with warty protuberances or short stubby branches

Lithothamnium aff. I. aucklandicum Foslie

Plate 270, figure 6

Lithothamnion aucklandicum Foslie, 1907, K. norske vidensk. selsk. Skr., no. 6, p. 18.

Lithothamnium ef. L. aucklandicum Foslie. Johnson, 1957, U.S. Geol. Survey Prof. Paper 280-E, p. 224, pl. 53, fig. 9.

Description.--Thallus develops either as thick crust or more often as crust with warty protuberances. $\mathrm{Hy}-$ pothallus either poorly developed or only partly shown in the fragments observed. Hypothallic cells about $7 \mu-11 \mu$ by $12 \mu-14 \mu$. Perithallus shows distinct irregular growth zones; cells $9 \mu-11 \mu$ by $6 \mu-8 \mu$. Conceptacles small but numerous, $223 \mu-242 \mu$ by $122 \mu-143 \mu$. Some show presence of sporangia (pl. 270, fig. 6). 
Remarks.-The Kita-Daitō-Jima material belongs to the same species as the specimen described by the writer from the Pleistocene of Saipan as $L$. cf. aucklandicum. It closely resembles the Recent $L$. notatum Foslie from Japan but has slightly larger conceptacles. Unfortunately, Foslie's description is brief, rather vague, and based on external structure, so clear comparison cannot be made.

Age: Pleistocene (?).

Locality: Kita-Daitō-Jima core, depth $53 \mathrm{ft}(16 \mathrm{~m})$.

Figured specimen: Tōhoku University colln., slide 124.

Lithothamnium funafutiense Foslie

Plate 270, figure 1

Lithothamnion funafutiense Foslie, 1900, K. norske vidensk. selsk. Skr., no. 1, p. 5-6.

Foslie and Printz, 1929, K, norske vidensk, selsk. Museet, Mon., p. 41, 56, pl. 12, fig. 3-4.

Description.-Thallus a thin irregular crust $0.125-$ $0.600 \mathrm{~mm}$ thick. In some places several thalli superimposed to form crustose mass. Hypothallus moderately developed (often about $155 \mu$ thick) ; rows gently to strongly curved. Cells rectangular, some rounded, $24 \mu-$ $35 \mu$ by $13 \mu-15 \mu$. Perithallus thin to moderately developed $(150 \mu-320 \mu$ thick). Cells square to slightly rectangular, $13 \mu-15 \mu$ by $10 \mu-15 \mu$. Conceptacles not present.

Remarks.-Foslie discusses this form in two papers but does not give a clear description, particularly with regard to range in cell dimensions. These specimens fit perfectly his description as to growth habit and general appearance of tissue. They show greater size range of cells than given by Foslie, but closely approximate his measurements. In general, core specimens have somewhat longer hypothallus cells and slightly wider perithallus cells. This might result from slightly oblique section. This above description based on several fossil specimens in two British Museum slides (534 and 726) . Crusts similar in appearance observed in number of other slides but slides too thick or material too recrystallized to permit accurate cell measurement.

Age: Pleistocene.

Locality: Funafuti, main boring, depth 452-798 (possibly 880) $\mathrm{ft}$.

Figured specimen: British Museum slide 534.

Lithothamnium cf. L. nitidum Foslie Plate 270, figures 3, 4

Lithothamnion nitidum Foslie, 1901, K. norske, vidensk. selsk Skr., no. 3, p. 4.

Foslie and Printz, 1929, K. norske. vidensk. selsk. Museet. Mon., p. 44, 54, pl. 6, fig. 10 .

Description.-Thallus crustose, thin, probably warty, 0.9-1.4 mm thick. Hypothallus absent or very poorly developed; when present, appears to consist of only few irregular cell rows; cells $6 \mu-8 \mu$ by $9 \mu-16 \mu$. Perithallus of compact rectilinear rows of cells; cells rectangular $6 \mu-10 \mu$ by $8 \mu-1+\mu$. Conceptacles large, flattened. Conceptacle cavities $578 \mu-807 \mu$ by $275 \mu-298 \mu$.

Remarks.-In growth habit, character, and size of conceptacles and perithallic cells this form agrees with Foslie's description of $L$. nitidum from Japan. However, in Foslie's species the hypothallus better developed and contains larger cells. The Kita-Daitō-Jima specimens are closely related to $L$. funafutiense Foslie but have much smaller hypothallic cells.

This species was observed in a number of slides from Kita-Daitō-Jima. Most of the material is considerably recrystallized.

Age: Probably Pleistocene.

Locality: Kita-Daitō-Jima. Surface material and depth 16 ft $(5 \mathrm{~m})$.

Figured specimens: Tōhoku University colln., slide 53, and Aoki colln., slide 196 (1)

\section{Lithothamnium cf. L. mirabile Conti}

Lithothamnion mirabile Conti, 1943, Palaeontographia Italica Mem. Paleont., v. 41 (new ser. v. 11), p. 43-44, pl. 5, fig. $2 ;$ pl. 8 , fig. 2.

Lithothamnium cf. L. mirabile Conti. Johnson, 1957, U.S. Geol. Survey Prof. Paper 280-E, p. 225, 48, fig. 3.

Description.-Thallus a thick irregular crust. Hypothallus well developed with curved rows of cells measuring $14 \mu-30 \mu$ by $8 \mu-13 \mu$. Perithallus shows irregular growth zones; cells rectangular $12 \mu-18 \mu$ by $8 \mu-$ $16 \mu$. No conceptacles observed.

Remarks.-The Eniwetok specimens appear to belong to the same species as the material described from Saipan under this name. They agree with Conti's description except for having a slightly greater range in size of the hypothallic cells.

Age: Miocene.

Locality: Eniwetok F-1, depth 1,978-2,003 ft (core).

Specimens: J-7 and K-3.

Division 3-Strongly branching forms

Lithothamnium sp. D

Plate 269, figures 4, 5

Description.-Long relatively slender $\mathrm{b} \mathrm{r}$ a $\mathrm{nch}$ es formed of large medullary hypothallus surrounded by a narrow perithallus. Medullary hypothallus formed of well-defined rows of rounded cells; rows curve toward margins at first gently, then sharply, to merge into perithallus. Hypothallic cells $23 \mu-33 \mu$ by $14 \mu-18 \mu$. Perithallus cells $9 \mu-15 \mu$ by $13 \mu-16 \mu$. Conceptacles unknown.

Remarks.-Represented in Eniwetok material by several fragments of branches. Cell dimensions of this 
species differ appreciably from any branching Lithothamnium previously described from Miocene. However, without more material and knowledge of conceptacles, it does not seem wise to give it a specific name.

Age: Early Miocene.

Locality: Eniwetok E-1, depths 2,003-2,028 and 2,802-2,808 ft. (core).

Figured specimens: E-1-1, USNM 40922 ; E-1-2, USNM 40804.

Genus MESOPHYLLUM Lemoine, 1928

Description.-Structurally this genus lies between Lithothamnium and Lithophyllum. Tissue resembles that of latter, with hypothallus commonly coaxial and a perithallus composed of well-defined layers of cells. In most cases, perithallus and tissue of branches show pronounced irregular growth zones. Conceptacles have numerous apertures similar to those of Lithothamnium.

Genus includes crustose and branching forms.

Known geologic range of $M$ esophyllum from Eocene to Recent, with greatest development during Miocene time.

Recent species live in littoral zone from just below tide level to depths as great as 175 feet; commonly found at depths of 30 to 100 feet.

For convenience in study, species arranged into three divisions based on growth habit.

Division 1.-Simple crusts.

2.-Short stubby branches.

3.-Strongly branching forms.

Following table gives dimensions and distribution of species identified.

Measurements (in microns) and distribution of species of Mesophyllum

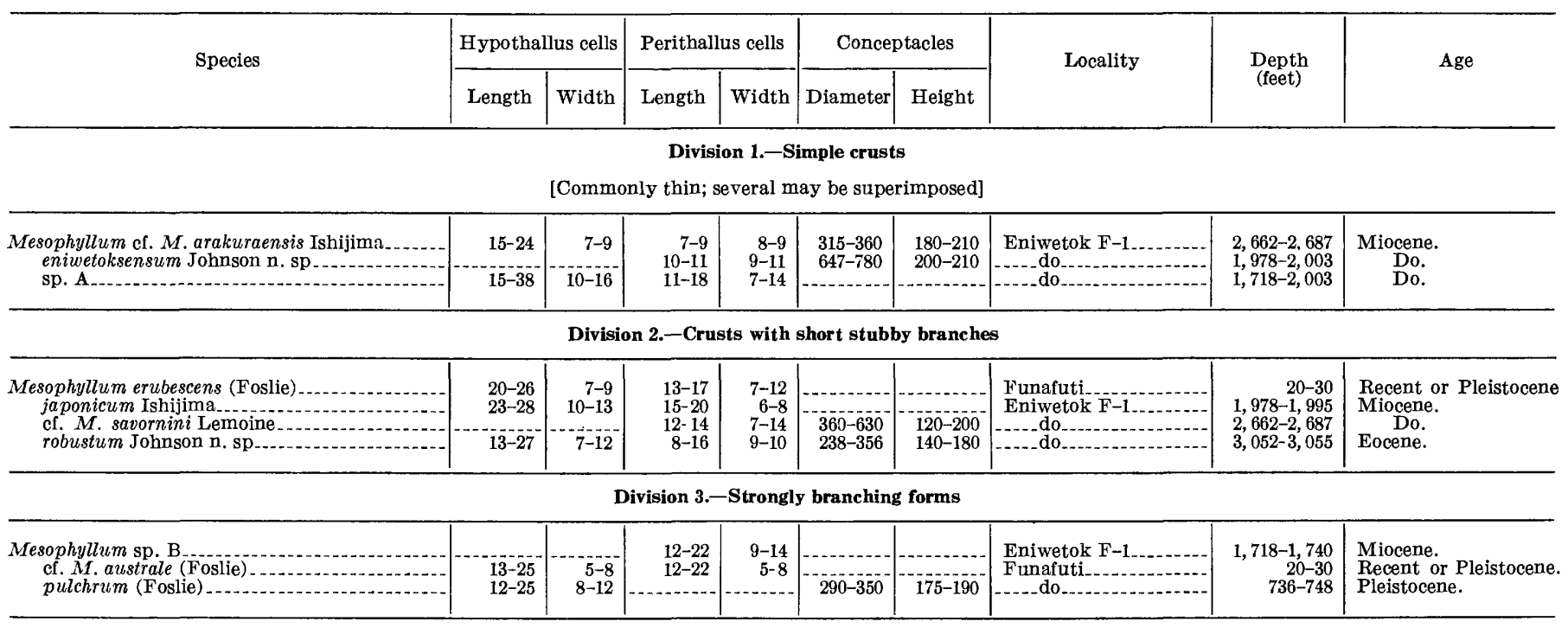

Division 1-Simple crusts

Mesophyllum cf. M. arakuraensis Ishijima

Plate 270, figure 5 ; plate 271 , figure 1

Mesophyllum arakuraensis Ishijima, 1954, Cenozoic coralline algae, western Pacific, p. 33, pl. 13, figs. 3-4.

Description.-Thallus small, irregular, crustose. Hypothallus coaxial, $150 \mu-400 \mu$ thick, of curved rows of rectangular cells $15 \mu-30 \mu$ by $7 \mu-13 \mu$. Perithallus contains irregular zones of layers of nearly square cells $7 \mu-9 \mu$ by $8 \mu-9 \mu$. Conceptacles small but high with multiple apertures. Size of conceptacle chambers $350 \mu-190 \mu, 350 \mu$ by $180 \mu, 479 \mu$ by $236 \mu$.

Remarks.-Represented by one fairly well preserved specimen and a few badly recrystallized examples. Specimens closely resemble Ishijima's material from lower Miocene (Burdigalian) of Japan but differ in having slightly shorter hypothallic cells.
Age: Miocene.

Locality: Eniwetok F-1, depth 1,978-2,003 and 2,662-2,687 ft (core).

Figured specimens: F-1-5-11 (2) large, USNM 40805; F-1-6-18 (3), USNM 40806.

\section{Mesophyllum eniwetokensum Johnson n. sp.}

Plate 272, figure 4

Description.-Thallus a very thin irregular crust; many thalli may grow superimposed to develop nodular mass. Hypothallus absent or consisting of only few layers of cells. Perithallic cells rectangular, $10 \mu-$ $14 \mu$ by $9 \mu-11 \mu$. Conceptacle chambers large, $647 \mu-780 \mu$ by $200 \mu-210 \mu$.

Remarks.-Mesophyllum eniwetokensum belongs to same group of genus as $M$. koritzae and $M$. Sancti Dionysii, which Lemoine (1939) found so abundantly developed in the Miocene of Algeria. It closely resembles $M$. Sancti Dionysii in growth habit, size of peri- 
thallic cells, and large size of conceptacles. It differs from that species, in however, that hypothallus is poorly developed or absent. Both species have large many apertured conceptacles but, whereas high and strongly arched in $M$. Sancti Dionysï, they are relatively low and flat topped in $M$. eniwetokensum.

Age: Miocene.

Locality: Eniwetok F-1 depth 1,978-2,003 ft (core).

Figured specimen: F-1-5-39 (3) holotype USNM 40807.

\section{Mesophyllum sp. A}

Plate 271, figure 3

Description.-Thallus an irregular crust or plate. Hypothallus moderately coaxial, $180 \mu-350 \mu$ thick; cells rectangular $15 \mu-38 \mu$ by $10 \mu-16 \mu$. Perithallus shows irregular growth zones, 5 to 8 layers of cells in each zone. Cells rectangular, $11 \mu-18 \mu$ by $7 \mu-14 \mu$. Conceptacles unknown.

Remarks.-A number of specimens of this species were observed. It differs in cell dimensions from previously decribed Miocene species. Without knowledge of conceptacles, it does not seem desirable to give it specific name.

Age: Miocene.

Locality: Eniwetok F-1, depths 1,718-2,003 ft (cores).

Figured specimen: F-1-5-12 (2), USNM 40808.

Division 2-Crusts with short stubby branches Mesophyllum erubescens (Foslie)

Plate 272, figure 6

Lithothamnion erubescens Foslie, 1900, K. norske. vidensk. selsk. Skr., no. 5, p. 9.

Weber van Bosse and Foslie, 1904, Siboga-Expeditie Mon. 61, p. 31-36, fig. 15-16, pl. 3, fig. 20.

Mesophyllum erubescens (Foslie) Lemoine, 1928, Soc. bot. France Bull. 5th ser. v. 75. P. 252.

Description.-Thallus a thin crust with thick stubby branches. Tissue of branches mainly medullary hypothallus though marginal hypothallus clearly developed. Tissue tends toward lenticular growth zones. Medullary hypothallus growth zones of 6-10 rows of rectangular cells; cells $20 \mu-26 \mu$ by $7 \mu-9 \mu$ Perithallus cells square to rectangular, $13 \mu-17 \mu$ by $7 \mu-12 \mu$ Conceptacles not present.

Remarks.-A widely distributed Recent species in the Pacific area. To judge by Foslie's several discussions it occurs in a number of growth forms and shows considerable range in cell dimensions.

The specimen studied agrees with Foslie's description.

Age: Pleistocene or Recent.

Locality: Funafuti, main boring, depth 20-30 ft.

Figured specimen: British Museum slide 615.

\section{Mesophyllum japonicum Ishijima}

Plate 271, figure 2

Hesophyllum japonicum Ishijima, 1954, Cenozoic coralline algae western Pacific, p. 32, pl. 12, figs. 1-5; pl. 13, fig. 1.

Description.-The plant forms an irregular crust from which arise short stubby branches. Hypothallus coaxial with cells $23 \mu-28 \mu$ by $10 \mu-13 \mu$. Tissue of perithallus and branches shows strong irregular growth zones, each consisting of layers of rectangular cells $15 \mu-20 \mu$ by $6 \mu-8 \mu$. No conceptacles present.

Remarks.-The structure, appearance, and cell dimensions agree closely with Ishijima's description and illustrations but the perithallis cells of the Eniwetok specimens average a little smaller.

Age: Miocene.

Locality: Eniwetok F-1, depth 1,978-1,985 ft (core).

Figured specimen: F-1-5-1, USNM 40809.

\section{Mesophyllum cf. M. savornini Lemoine}

Plate 271, figure 4

I esophyllum savornini Lemoine, 1939, Mat. Carte géol. de l'Algerie, ser. 1, Paléont., no. 9, p. 83, figs. $43-46$.

Johnson, 1957, U.S. Geol. Survey Prof. Paper 280-E, p. 227, pl. 52, fig. 8.

Description.-Thallus develops crust, bearing short stubby branches that show strong growth zones. Each composed of layers of rectangular cells. The cells measure $12 \mu-14 \mu$ by $7 \mu-14 \mu$. Conceptacle chambers large, relatively low, and flat on top. Chambers $360 \mu-$ $630 \mu$ by $120 \mu-200 \mu$.

Remarks.-Represented by several fragments of branches. The character of tissue, cell dimensions, and large size of conceptacles agree with those of Lemoine's type, and with specimens described by author from the Miocene of Saipan.

Age: Miocene.

Locality: Eniwetok F-1, depth 2,662-2,687 ft (core).

Figured specimen: N-2, USNM 40944.

Mesophyllum robustum Johnson n. sp.

Plate 271, figure 6

Description.-Thallus a thick irregular crust, probably with rounded protuberances. Well-developed coaxial hypothallus $200 \mu-260 \mu$ thick. Hypothallic cells $13 \mu-27 \mu$ by $7 \mu-12 \mu$. Perithallus consists of irregular growth bands, which may appear lenticular in section. Cells $8 \mu-16 \mu$ by $7 \mu-10 \mu$. Conceptacles small but highly arched. They measure $356 \mu$ by $169 \mu, 301 \mu$ by $180 \mu$, $238 \mu$ by $141 \mu$. Some traces of sporangia in conceptacles. Sporangia show heights of $33 \mu-55 \mu$ and diameters of $26 \mu-40 \mu(30 \mu)$.

Remarks.-Species closely resembles $M$. heteroclitum Lemoine in cell dimensions and size of conceptacles but 
has better developed coaxial hypothallus; the hypothallus of $M$. heteroclitum consists of few horizontal layers of cells very regularly arranged. $M$. robustum also closely resembles Lithothamnium camarasae Pfender but differs from it also in character and development of hypothallus.

Age: Late Eocene.

Locatity: Eniwetok F-1, depth 3,052-3,055 ft (core).

Figured specimen: F-1-7-7 (2) large, Holotype USNM 40812.

Division 3.-Strongly branching forms

Mesophyllum sp. B

Plate 272, figure 5

Description.-Plants with long narrow spines or branches that are composed of arched layers of rectangular cells arranged in pronounced growth zones; each zone with 6 to 12 layers of cells; cells measure $12 \mu-22 \mu$ by $9 \mu-14 \mu$. Conceptacles unknown.

Remarks.-Represented by several worn fragments. They differ from any branching Miocene species hitherto described from Pacific. Nearest described species M. commune Lemoine from Miocene of Algeria. Eniwetok species has slightly larger cells. Better specimens and knowledge of conceptacles needed before naming species.

Age: Miocene.

Locality: Eniwetok F-1, depth 1.718-1,740 ft (core).

Figured specimen: H2, USNM 40811.

\section{Mesophyllum cf. M. australe (Foslie)}

Lithothamnion coralloides f. australis Foslie, 1895, K. norske vidensk. selsk. Skr., no. 2, p. 9.

Lithothamnion austrate Foslie, 1900, K. norske. vidensk. selsk. Skr., no. 5, p. 13.

Weber van Bosse and Foslie, 1904, Siboga-Expeditie Mon. 61, p. 24-29, figs. 10-12, pl. 2, figs. 10-51.

Mesophyllum australe (Foslie) Lemoine, 1928, Soc. bot. France Bull. 5th ser. v. 75, p. 252.

Description.-Thallus crustose with short stubby branches. Hypothallus moderately developed coaxial; cells $13 \mu-25 \mu$ by $5 \mu-8 \mu$. Perithallus composed of fairly regular rows of cells measuring $12 \mu-22 \mu$ by $5 \mu-8 \mu$. Conceptacles absent.

Remarks.-Several fragments probably belonging to this species, or one closely related to it, were observed. Cells slightly longer than those of type but Foslie referred to L. australe as a highly variable form. Without conceptacles, an exact determination cannot be made.

Age: Pleistocene or Recent.

Locality: Funafuti, depths 20-23 ft and probably from depth $957 \mathrm{ft}$.

Specimens: British Museum slides 598, 611, 615.
Mesophyllum pulchrum (Foslie)

Plate 271, figure 5

Lithothamnion pulchrum Foslie, 1901, K. norske. vidensk. selsk. Skr., no. 3, p. 3.

Weber van Bosse and Foslie, 1904, Siboga-Expeditie Mon. 61 , p. 36-38, fig. 18, pl. 4 ,

Mesophyllum pulchrum (Foslie) Lemoine, 1928, Soc. bot. France Bull. 5th ser. v. 75, p. 252.

Description.--Thallus massive, branching, represented by fragments of thick branches. Basal hypothallus missing. Medullary hypothallus shows distinct rather regular cup-shaped growth zones. Cells appear rounded rectangular, longer than wide. Recrystallization prevents accurate cell measurements, but they are approximately $12 \mu-25 \mu$ by $8 \mu-12 \mu$. Perithallus not observed around margins of branches. Three measured conceptacles gave diameters of $290 \mu-$ $350 \mu$ and heights of $175 \mu-190 \mu$.

Remarks.-Specimen badly recrystallized. Growth habit and general appearance of tissue suggest that dimensions of cells and conceptacles of this species fall within dimension range of Recent examples from East Indies.

Age: Pleistocene.

Locality: Funafuti, main boring, depth $736-748 \mathrm{ft}$.

Figured specimen: British Museum slide 688.

\section{Genus LITHOPHYLIUM Philippi, 1837}

In this genus thallus is polystromatic, forming a crust or crust-developing protuberances or erect branches; differentiated into hypothallus, perithallus, and epithallus. Hypothallus is several to many layers thick, commonly coaxial. Hypothallic cells are mostly horizontally elongated. The perithallus usually is thinner than the hypothallus with cells typically isodiametric but sometimes elongated. The epithallus is 1 to 4 layers thick, cells flattened parallel to the outer surface. It is seldom calcified; hence is rarely observed on fossil material. The conceptacles have a single large pore.

Lithophyllum is abundantly represented in the collections studied both in number of species and of individuals.

For convenience in study, the species are arranged into three divisions based on the growth habit.

Division 1.-Simple crusts.

2.-Crusts with warty proturbances or short stubby branches.

3.-Strongly branching forms.

The following table gives the dimensions and distribution of the species identified. 
Measurements (in microns) and distribution of species of Lithophyllum

\begin{tabular}{|c|c|c|c|c|c|c|c|c|c|}
\hline \multirow{2}{*}{ Species } & \multicolumn{2}{|c|}{ Hypothallus cells } & \multicolumn{2}{|c|}{ Perithallus cells } & \multicolumn{2}{|c|}{ Conceptacles } & \multirow{2}{*}{ Locality } & \multirow{2}{*}{$\begin{array}{l}\text { Depth } \\
\text { (feet) }\end{array}$} & \multirow{2}{*}{ Age } \\
\hline & Length & Width & Length & Width & Diameter & Height & & & \\
\hline \multicolumn{10}{|c|}{ Division 1.-Simple crusts } \\
\hline \multicolumn{10}{|c|}{ [Commonly thin; several may be superimposed] } \\
\hline $\begin{array}{l}\text { Lithophyllum acanthinum Foslie } \\
\text { hanzawae Johnson } \mathrm{n} \text {. sp } \\
\text { johnsoni Ishijima } \\
\text { cf. L. lingusticum Airoldi } \\
\text { megacrustum Johnson and Ferris. } \\
\text { cf. L. prelichenoides Lemoine } \\
\text { quadratum Ishijima } \\
\text { samoense Foslie } \\
\text { stefaninii Airoldi } \\
\text { thikombian Johnson and Ferris. }\end{array}$ & $\begin{array}{l}18-25 \\
12-30 \\
14-22 \\
16-25 \\
10-18\end{array}$ & $\begin{array}{r}8-14 \\
9-12 \\
9-11 \\
8-11 \\
15-76 \\
\\
8-9 \\
27-43 \\
9-15 \\
9-26 \\
24-33\end{array}$ & $\begin{array}{r}10-12 \\
9-12 \\
5-7 \\
8-16 \\
12-14\end{array}$ & $\begin{array}{r}7-14 \\
7-10 \\
7-8 \\
8-10 \\
27-83 \\
\\
7-11 \\
17-30 \\
5-7 \\
13-25 \\
16-27\end{array}$ & $\begin{array}{r}125-170 \\
225-447 \\
185 \\
208-246 \\
153-171 \\
\end{array}$ & $\begin{array}{r}36-55 \\
87-102 \\
81 \\
101-109 \\
89-97\end{array}$ & 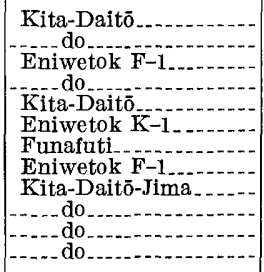 & $\begin{array}{r}25-383 \\
180 \\
1,975-2,000 \\
3,655-3,665 \\
0-220 \\
400 \\
1,000 \\
1,978-2,003 \\
30 \\
30 \\
23-396 \\
393\end{array}$ & $\begin{array}{l}\text { Pleistocene. } \\
\text { Do. } \\
\text { Miocene. } \\
\text { Eocene. } \\
\text { Pleistocene or Recent. } \\
\text { Do. } \\
\text { Do. } \\
\text { Miocene. } \\
\text { Pleistocene(?). } \\
\text { Do. } \\
\text { Pliocene-Pleistocene. } \\
\text { Miocene(?). }\end{array}$ \\
\hline \multicolumn{10}{|c|}{ Division 2.-Crusts with warty protuberances or short stubby branches } \\
\hline $\begin{array}{l}\text { Lithophyllum okamurae Foslie... } \\
\text { sp. A }\end{array}$ & $12-16$ & $30-45$ & $\begin{array}{l}12-22 \\
11-14\end{array}$ & $\begin{array}{l}8-10 \\
8-10\end{array}$ & $\begin{array}{l}161-235 \\
195-210\end{array}$ & $\begin{array}{r}60-78 \\
90-160\end{array}$ & $\begin{array}{l}\text { Kita-Daitō-Jima...... } \\
\text { Eniwetok E-1........ }\end{array}$ & (1) 2,655 & $\begin{array}{l}\text { Pleistocene or Recent. } \\
\text { Miocene. }\end{array}$ \\
\hline \multicolumn{10}{|c|}{ Division 3.-Strongly branching forms } \\
\hline Lithophyllum kladosum Johnson.. & $28-65$ & $10-17$ & $10-23$ & $9-17$ & $315-375$ & $160-250$ & Eniwetok F-1......... & $1,720-2,000$ & Miocene. \\
\hline $\begin{array}{l}\text { ef. } L \text {. kotschyanum Unger } \\
\text { prof undum Johnson. }\end{array}$ & $\begin{array}{r}9-33 \\
20-41\end{array}$ & $\begin{array}{l}7-14 \\
9-15\end{array}$ & $\begin{array}{r}11-30 \\
8-16\end{array}$ & $\begin{array}{l}7-15 \\
9-13\end{array}$ & -..... & & Kita-Daitō-Jima...... & $\begin{array}{r}37-347 \\
1,978-2,003\end{array}$ & $\begin{array}{l}\text { Pleistocene. } \\
\text { Miocene. }\end{array}$ \\
\hline sp. $B_{1} \ldots \ldots \ldots$ & $30-36$ & $15-18$ & $9-15$ & $10-15$ & & & Kita-Daitō-Jima........ & & Do. \\
\hline
\end{tabular}

1 Surface.

\section{Division 1-Simple crusts Lithophyllum acanthinum Foslie}

Plate 273, figure 1

Lithophyllum acanthinum Foslie, 1907, K. norske. vidensk. selsk. Skr., no. 6, p. 26.

Description.-Thallus a crust 2-5 mm thick. Hypothallus coaxial; cells rectangular $18 \mu-25 \mu$ by $8 \mu-14 \mu$ Perithallus thin, cells rectangular, measuring $8 \mu-15 \mu$ by $7 \mu-14 \mu$. No conceptacles present.

Remarks.-Represented in Kita-Daitō-Jima collection by number of poorly preserved fragments, all infertile. Growth habit and cell dimensions agree with Foslie's description of $L$. acanthinum from central Japan although some of perithallic cells attain greater length.

Age: Pleistocene and possibly late Pliocene.

Locality: Kita-Daitō-Jima core, depth $24 \mathrm{ft}(7.5 \mathrm{~m})$ and $380 \mathrm{ft}(115 \mathrm{~m})$.

Figured specimen: Tōhoku University colln., slide 656; slide 43 , not figured.

Lithophyllum hanzawae Johnson n. sp.

Plate 272, figures 2, 3

Description.-Irregular crust $1.45-2.10 \mathrm{~mm}$ thick.
Hypothallus composed of cell rows curving up and down from center. Walls of cell rows clearly defined; walls between cells in row thin and obscure. Cells $9 \mu-$ $12 \mu$ by approximately $12 \mu-30 \mu$. Perithallus of regularly arranged cell rows; cells $7 \mu-10 \mu$ by $7 \mu-11 \mu$. Conceptacles abundant, small, cavities measuring $125 \mu-$ $170 \mu$ by $36 \mu-55 \mu$ high. Tops slightly arched and perforated by one large pore.

Remarks.-This species belongs to small group of encrusting Lithophyllum characterized by unusually small size of perithallic cells and conceptacles. It is closely related to Foslie's highly variable $L$. yendoi, but differs by having a different type of hypothallus, which is more strongly developed, and in having smaller conceptacles and slightly larger cell dimensions.

The species is named for Dr. Shoshiro Hanzawa of the Institute of Geology and Paleontology of Tōhoku University who carefully studied the Kita-Daito--Jima cores, described the Foraminifera (Hanzawa 1940-41), and assisted in the present restudy.

Age: Pleistocene (?).

Locality: Kita-Daitō-Jima core depth $53 \mathrm{ft}(16 \mathrm{~m})$.

Holotype: Tōhoku University, Aoki colln. slide 141. 


\section{Lithophyllum johnsoni Ishijima}

Lithophyllum johnsoni Ishijima, 1954, Cenozoic coralline algae western Pacific, p. 42, pl. 25, fig. 4 ; pl. 26, figs. 1-3; pl. 27, fig. 3.

Description.-Thallus crustose, thin; well-developed coaxial hypothallus and moderately developed perithallus. Hypothallic cells $14 \mu-22 \mu$ by $9 \mu-11 \mu$. Perithallic cells small, rectangular to square in section, measuring $8 \mu-11 \mu$ by $7 \mu-8 \mu$. Conceptacles unknown.

Remarks.-The Eniwetok material fits Ishijima's species from the Miocene of Japan. Represented by a number of specimens in the Eniwetok collection.

Age: Miocene.

Locality: Eniwetok F-1, 1975-2,000 ft (core).

Lithophyllum cf. L. lingusticum Airoldi Plate 272, figure 1

Lithophyllum lingusticum Airoldi, 1932, Paleontographia Italica Mem. Paleont., v. 33 (new ser., v. 3), p. 72-73, pl. 12, figs. 2-3.

Description.-Thallus a thin crust. Hypothallus coaxial, $160 \mu-250 \mu$ thick; cells $16 \mu-25 \mu$ by $8 \mu-11 \mu$. Perithallus thin, $45 \mu-75 \mu$ thick, of nearly cubic cells measuring $8 \mu-10 \mu$ on a side. Conceptacles unknown.

Remarks.-No Eocene species of Lithophyllum with corresponding cell dimensions has been described previously. The closest described species is $L$. lingusticum Airoldi from the Oligocene of Somali which develops as a thin crust with short branches and has cell dimensions about the same as the Eniwetok specimens.

Age: Late Eocene.

Locality: Eniwetok F-1, 3,655-3,665 ft (core).

Figured specimen: F-1-9-9, USNM 40814.

Lithophyllum megacrustum Johnson and Ferris

Lithophyllum megacrustum Johnson and Ferris, 1950, B. P Bishop Mus. Bull. 201, p. 16, pl. 7, figs. D, E.

Johnson, 1957, U.S. Geol. Survey Prof. Paper 280-E, p. 228, pl. 54, fig. 8 ; pl. 55, fig. 1 .

Description.-Plant has thick crust as much as or more than a centimeter thick. In some cases several superimposed thalli form crust. Hypothallus absent or slightly developed; commonly consists of single row of oblique cells, at most of only few rows of long cells; cells measure $6 \mu-18 \mu$ by $12 \mu-76 \mu$, commonly $11 \mu-16 \mu$ by $28 \mu-48 \mu$. Perithallus consists of regular rows of long rectangular cells with thick walls. Some areas are irregular, especially around conceptacles. In some rows, cells are arranged obliquely to row walls and there may be suggestion of alternation of rows of cells of slightly different length. Cell walls distinct and thick; cells show an unusual size range, measuring $8 \mu-18 \mu$ by $21 \mu-$ $86 \mu$, commonly $9 \mu-14 \mu$ by $31 \mu-54 \mu$. Conceptacle chambers $300 \mu-447 \mu$ by $67 \mu-140 \mu$.
Detailed measurements of a number of specimens studied from Kita-Daitō-Jima, Eniwetok, and Funafuti are as follows.

\begin{tabular}{|c|c|c|c|c|}
\hline Sample & $\begin{array}{l}\text { Depth } \\
\text { (feet) }\end{array}$ & $\underset{\text { (microns) }}{\text { Hypothallus }}$ & $\begin{array}{l}\text { Perithallus } \\
\text { (microns) }\end{array}$ & $\begin{array}{c}\text { Conceptacles } \\
\text { (microns) }\end{array}$ \\
\hline \multicolumn{5}{|c|}{ Kita-Daitō-Jima } \\
\hline 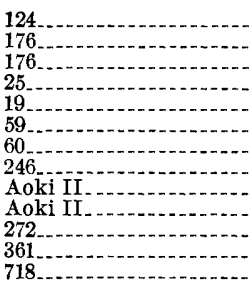 & $\begin{array}{r}0 \\
0 \\
0 \\
18 \\
20 \\
29 \\
29 \\
160\end{array}$ & $\begin{array}{r}12-16 \times 21-25 \\
10-14 \times 40-62 \\
11-18 \times 39-80 \\
8-9 \times 29-47 \\
10-14 \times 31-76 \\
11-13 \times 45-63 \\
13-18 \times 28-34 \\
11-15 \times 15-27 \\
14-15 \times 27-47\end{array}$ & $\begin{array}{r}10-14 \times 41-68 \\
9-12 \times 21-25 \\
9-12 \times 37-82 \\
9-14 \times 27-42 \\
11-14 \times 22-36 \\
9-12 \times 34-42 \\
8-12 \times 30-61 \\
9-14 \times 38-83 \\
11-18 \times 34-54 \\
9-17 \times 40-44 \\
9-14 \times 31-37 \\
8-12 \times 27-46 \\
14-15 \times 31-48\end{array}$ & $\begin{array}{l}300-447 \times 81-98 \\
425 \times 92 \\
320-403 \times 67-91 \\
278 \times 92 \\
385 \times 109 \\
302-374 \times 90-10 \\
310 \times 140 \\
302-306 \times 76-93 \\
225-323 \times 73-89 \\
356-383 \times 86-88 \\
430 \times 130 \\
328 \times 81\end{array}$ \\
\hline \multicolumn{5}{|c|}{ Eniwetok } \\
\hline $\mathrm{K}-1 \ldots$ & 400 & $7-14$ & $7-14 \times 40-50$ & Not present. \\
\hline \multicolumn{5}{|c|}{ Funafuti } \\
\hline Slide 774 & 1,000 & & $10-15 \times 41-50$ & $313-316 \times 82-84$ \\
\hline
\end{tabular}

Remarks.-Most abundant species in the Kita-DaitōJima cores. It resembles modern Lithophyllum papillosum (Zan.) Foslie of Mediterranean and tropical Pacific but differs in forming much thicker crust and, in most cases, has a more regular tissue.

Age: Pleistocene and probably Recent.

Locality: Kita-Daitō-Jima core, surface to depths of $220 \mathrm{ft}$ $(66 \mathrm{~m})$. Funafuti core, depth 1,000 ft. Eniwetok core K-1, depth $400 \mathrm{ft}$.

Specimens: Tōhoku University colln., slides 25 and 176, and Aoki II.

\section{Lithophyllum cf. L. prelichenoides Lemoine}

Lithophyllum prelichenoides Lemoine, 1918, Soc. géol. France Bull., ser. 4, v. 17, p. 262, figs. 8, 9 [imprint date 1917].

Lemoine, 1939, Mat. Carte géol. de l'Algerie, ser. 1, Paléont., no. 9, p. 99, figs. 65-66, p. 107.

Johnson, 1957, U.S. Geol. Survey Prof. Paper 280-E, p. 229, pl. 49 , figs. 1-2.

Description.-Thallus a thin crust or irregular plate consisting of well-developed coaxial hypothallus and thin perithallus. Hypothallic cells $14 \mu-18 \mu$ by $8 \mu-9 \mu$. Perithallic cells nearly cubic, $10 \mu-12 \mu$ by $7 \mu-11 \mu$. Conceptacle cavity $185 \mu$ by $81 \mu$.

Remarks.-In growth habit, structure, and cell dimensions Eniwetok specimens resemble this widespread Miocene species. They differ from typical L. prelichenoides only in having slightly smaller average size of hypothallic cells.

Age: Miocene.

Locality: Eniwetok F-1, 1,978-2,003 ft (core) . 


\section{Lithophyllum quadratum Ishijima}

Plate 273, figure 2

Lithophyllum quadratum Ishijima, 1954, Cenozoic coralline algae western Pacific, p. 37-38, pl. 22, fig. 5a, b; pl. 23, fig. 1-4.

Description.-Thallus a thin crust commonly about $0.5 \mathrm{~mm}$ thick; several or many thalli may grow superimposed to form irregular flattened masses. Hypothallus thin and irregular; cells $10 \mu-14 \mu$ by $27 \mu-43 \mu$. Perithallus shows rectilinear pattern in section. Tissue may show irregular growth zones. Cells measure $9 \mu-12 \mu$ by $17 \mu-30 \mu$. Conceptacle cavities $208 \mu-246 \mu$ by $101 \mu-109 \mu$.

Remarks.-Characteristic features of this species, rectilinear pattern of normal perithallic tissue, relatively large size of perithallic cells, diameter of the conceptacles, and irregularly zoned appearance of sections of crusts. Kita-Daitō-Jima specimens agree with Ishijima's description and illustrations except in having somewhat narrower perithallic cells. Species closely related to the Recent species $L$. yessoense Foslie, differing only in having longer hypothallic cells.

Age: Pleistocene (?).

Locality: Kita-Daitō-Jima, core depth $29 \mathrm{ft}(8.97 \mathrm{~m})$.

Figured specimen: Töhoku University colln., slide 63.

\section{Lithophyllum samosense Foslie}

Plate 273, figures 5, 6

Lithophyllum samosense Foslie, 1906, K. norske vidensk. selsk. Skr., no. 2, p. 20.

Description.-Thallus a thin crust on other algae or objects. Crusts $0.3-0.6 \mathrm{~mm}$ thick. Hypothallus irregularly developed, apparently varying with irregularities in substratum; hypothallic cells $5 \mu-7 \mu$ by $9 \mu-15 \mu$. Perithallus shows irregular growth zones, cells $5 \mu-7 \mu$ by $5 \mu-7 \mu$. Conceptacles small, shaped like lima beans, in section $153 \mu-171 \mu$ by $89 \mu-97 \mu$.

Remarks.-Foslie described two species of thin crustose Lithophyllum from Pacific, $L$. samoense and $L$. yendoi. These species differ only in cell dimensions and size of conceptacles. They appear to have much the same geographic range. Specimens from KitaDaitō-Jima cores exactly fit Foslie's description of $L$. samoense but they are close to material from Saipan referred by writer to $L$. yendoi; the Kita-Daitō-Jima specimens have slightly larger conceptacles.

Age: Pleistocene (?).

Locality: Kita-Daitō-Jima, depth $29 \mathrm{ft}(8.97 \mathrm{~m})$.

Figured specimen: Tōhoku University colln., slides 61 and 256.
Lithophyllum stefaninii Airoldi

Plate 273, figures 3,4

Lithophyllum stefaninii Airoldi, 1933. Palaeontographia Italica Men. Palaeont., v. 32, supp. 1, p. 90, pl. 8, fig. 2.

Johnson, 1957, U.S. Geol. Survey Prof. Paper 280-E, p. 228 , pl. 54, fig. 4 .

Description.-Thallus a thin crust with well-defined hypothallus and perithallus. Hypothallus moderately coaxial, cells oval to rectangular, measuring $9 \mu-11 \mu$ by $9 \mu-26 \mu$. Perithallus quite regular, cells rectangular $8 \mu-16 \mu$ by $13 \mu-25 \mu$. No conceptacles present.

Remarks.-Relatively common in Kita-Daitō-Jima material. In growth habit, appearance of tissue, and cell dimensions this form agrees with Airoldi's description of material from Pleistocene of Red Sea region.

Age: Probably Pliocene-Pleistocene.

Locality: Kita-Daitō-Jima core, depth $22 \mathrm{ft}(7 \mathrm{~m})$ and 396 ft $(120 \mathrm{~m})$.

Figured specimens: Tōhoku University colln., slides 62 and 661.

\section{Lithophyllum thikombian Johnson and Ferris}

Plate 273, figure 7

Lithophyllum thikombian Johnson and Ferris, 1950, B. P. Bishop Mus. Bull. 201, p. 17, pl. 6, figs. B and D.

Description.-Thallus crustose, consisting of welldeveloped coaxial hypothallus and some perithallic tissue. Hypothallus $0.29 \mathrm{~mm}$ thick, composed of rectangular cells $15 \mu-20 \mu$ by $24 \mu-33 \mu$. Perithallus of regular layers of cells; cells $12 \mu-14 \mu$ by $16 \mu-27 \mu$. Conceptacles not present.

Remarks.-This species is represented by several abraded fragments in core. In general appearance of tissue and in cell measurements it agrees closely with $L$. thikombian described from Miocene of Lau, Fiji.

Age: Probably Miocene.

Locality: Kita-Daitō-Jima core, depth $363 \mathrm{ft}(110 \mathrm{~m})$ and 389 ft. $(119 \mathrm{~m})$

Figured specimen: Tōhoku University colln., slide 656.

\section{Division 2-Crusts with warty protuberances Lithophyllum okamurae Foslie} Plate 274, figure 1

Lithophyllum okamurae Foslie, 1909, K. norske vidensk. selsk. Skr., no. 2, p. 30-31.

Description.-Thallus a thick crust from which develop warty protuberances. Hypothallus poorly to moderately developed; cells rectangular $12 \mu-16 \mu$ by $30 \mu-45 \mu$. Perithallus thick, showing some growth zones; cells square to oblong in section, measuring $12 \mu-$ $22 \mu$ by $8 \mu-10 \mu$. Conceptacles abundant, small; cav- 
ities measure $161 \mu-235 \mu$ in diameter and $60 \mu-78 \mu$ high. Remarks.-Foslie described this as a species with a variety of growth forms from Japan and East Indies. Forms include warty crusts and nodular crusts with short thick branches. Specimens studied fit description.

Age: Pleistocene or Recent.

Locality: Kita-Daitō-Jima, surface outcrops.

Figured specimen: Tōhoku University colln., slide 176.

\section{Lithophyllum sp. A}

Description.--Thallus a thick crust or mammillated mass. Hypothallus not observed. Perithallus of small rectangular cells in poorly defined layers. Cells measure $11 \mu-14 \mu$ long and $8 \mu-10 \mu$ wide. Conceptacles small gently arched to nearly flat on top. Conceptacle chambers measure $195 \mu-210 \mu$ in diameter and $90 \mu-160 \mu$ in height.

Remarks.-Represented in Eniwetok slides by two worn fragments. They differ from previously described Miocene species, but are too poorly preserved to use as base for a new species. The nearest described species is Lithophyllum irregularis Ishijima which, however, has much larger and flatter conceptacles.

Age: Miocene.

Locality: Eniwetok E-1, depth 2,650-2,660 ft (cuttings).

Division 3-Strongly branching forms

Lithophyllum kladosum Johnson

Plate 272, figure 7 ; plate 274, figures 4,5

Lithophyllum kladosum Johnson, 1954, U.S. Geol. Survey Prof. Paper 260-M, p. 539, pl. 192.

Description.-Long slender branches composed of well-developed medullary hypothallus surrounded by a relatively thick marginal perithallus. Hypothallic cells oblong in section, arranged in arched layers. Cells show considerable range in size of different rows of same specimen, measuring $28 \mu-65 \mu$ high and $10 \mu-17 \mu$ wide. Perithallic cells cubic, in layers nearly perpendicular to the layers of the hypothallus; cells measure $10 \mu-23 \mu$ by $9 \mu-17 \mu$. Conceptacles marginal, highly arched. Conceptacle chambers measure $315 \mu-375 \mu$ in diameter and $160 \mu-250 \mu$ in height.

Remarks.-In general appearance, cell measurements, and all structural features Eniwetok specimens agree with material described from beds of same age in Bikini drill hole. In addition several fertile specimens obtained.

This species is most abundantly represented of all species studied from Eniwetok material. It was found in both drill holes $\mathrm{F}-1$ and $\mathrm{E}-1$, in cores and in cuttings.

Age: Miocene.

Locality: Eniwetok F-1, depth 1,720-2,000 ft (cores) ; E-1, depth 2,100-2,680 ft (cuttings).

Figured specimens: USNM 40815, and 40816, and 40924.
Lithophyllum cf. L. kotschyanum (Unger) Foslie

Plate 274, figures 2, 3

Lithophyllum kotschyanum (Unger) Foslie, 1909, K. norske vidensk. selsk. Skr., no. 2, p. 34-36.

Johnson, 1957, U.S. Geol. Survey Prof. Paper 280-E, p. 230, pl. 57, fig. 1 ; pl. 58, fig. 1.

Description.-Thallus a crust with thick stubby branches that contain thick medullary hypothallus and moderately to well-developed marginal perithallus. Medullary hypothallus built of curved layers of rectangular cells; considerable range in cell size both in different layers and in same layer from center to edge. Cells measure $9 \mu-33 \mu$ by $7 \mu-14 \mu$, commonly $12 \mu-15 \mu$ by $8 \mu-11 \mu$. In some cases there appears a fairly regular alternation of several layers of long cells with several layers of short cells (plate 8, fig. 3). Marginal perithallus of well-defined cell layers, cells $11 \mu-30 \mu$ long and $7 \mu-15 \mu$ wide, commonly $11 \mu-20 \mu$ by $9 \mu-11 \mu$. Conceptacles rather flattened on top with large central aperture; cavities $401 \mu-512 \mu$ in diameter and $93 \mu-180 \mu$ high.

Remarks.-Foslie's Recent species is very variable form. He named five forms, which grade one into another. There is corresponding variation in cell size and structural detail, some showing alternating layers of long and short cells, some not. The species has been reported from Red Sea to Samoa. The author has collected it around Guam and Saipan. The Kita-DaitōJima material agrees with Foslie's description except for having larger conceptacles. The type material has conceptacle diameters of $250 \mu-400 \mu$, while our specimens show diameters from $401 \mu-512 \mu$, commonly $401 \mu-$ $440 \mu$.

Numerous specimens attributed to this species were observed in the Kita-Daitō-Jima core at depths ranging from 10 to 100 meters ( 30 to $320 \mathrm{ft}$ ); all were worn branches or fragments.

Age: Pleistocene (?).

Locality: Kita-Daitō-Jima core, depth $35 \mathrm{ft}(10.73 \mathrm{~m})$ and $345 \mathrm{ft}(105 \mathrm{~m})$.

Figured specimen: Tōhoku University colln., silde 73.

Lithophyllum profundum Johnson

Plate 275 , figure 5

Lithophyllum profundum Johnson, 1954, U.S. Geol. Survey Prof. Paper 260-M, p. 539-540, pl. 191, figs. 5-7.

Description.-Plant forms clusters of long relatively slender branches. Each branch consists of moderately wide medullary hypothallus and much narrower perithallus. Hypothallus of arched layers of rectangular cells $20 \mu-41 \mu$ long and $9 \mu-15 \mu$ wide. Perithallus formed of layers of small rectangular cells $8 \mu-16 \mu$ by $9 \mu-13 \mu$. Perithallus shows growth zones. Conceptacle chambers $300 \mu-360 \mu$ in diameter and $190 \mu-225 \mu$ in height. 
Remarks.-The structure, growth habit, and cell dimensions agree with species described from Bikini, based on fragments of infertile branches. Eniwetok collections contain larger pieces which give better idea of growth habit, and they include some with conceptacles.

Age: Miocene.

Locality: Eniwetok F-1, depth 1,978-2,003 ft (core); E-1. 2,690-2,700 ft (cuttings).

Figured specimen: F-1-5-42, USNM 40913.

\section{Lithophyllum sp. B}

Description.-Worn fragment of branch with welldeveloped medullary hypothallus of gently arched layers of rectangular cells $30 \mu-36 \mu$ long and $15 \mu-18 \mu$ wide. Most of marginal perithallus worn off. Perithallic cells nearly square, $9 \mu-15 \mu$ by $10 \mu-15 \mu$, averaging $10 \mu-11 \mu$ square in section. Conceptacles absent.

Remarks.-This form does not exactly fit description of any previously described Miocene species. Because no conceptacles are present and it is represented by only one specimen in Kita-Daitō-Jima collection, it does not seem desirable to name it as new species.

Specimen resembles fragment found in Bikini core at depth of 2,040 feet (Miocene). It was described ( $\mathbf{J}_{\mathrm{ohn}}$ son $1954 \mathrm{~b}$, p. 541) under name of Goniolithon cf. G. frutescens Foslie. Growth habit and cell dimensions are similar. Bikini specimen shows more pronounced growth zones than Kita-Daitō-Jima specimen.

Age: Miocene.

Locatity: Kita-Daitō-Jima core, depth $492 \mathrm{ft}(150 \mathrm{~m})$.

\section{Genus GONIOLITHON Foslie, 1900}

The genus Goniolithon is closely related to Lithophyllum, having the same type of hypothallus and conceptacles. It resembles Porolithon in having numerous megacells in the perithallic tissue; however, these occur in small rows perpendicular to the outer surface, not in lenses parallel to the surface as in $\mathrm{Po}$ rolithon. In many cases there are only 2 or 3 megacells in a group, one above the other. Today, the genus is represented in the tropical Pacific by a small number of widely distributed species.

\section{Goniolithon frutescens Foslie}

Goniolithon (Cladolithon) frutescens Foslie, 1900, K. norske vidensk. selsk. Skr., no. 1, p. 9-10.

Goniolithon frutescens Foslie, 1900, The fauna and geography of the Maldive and Laccadive Archipelagos, p. 468, pl. 35 , figs. 5-6.

Weber van Bosse and Foslie, 1904, siboga-Expeditie Mon. 61, p. 53, pl. 10 figs. 10-11.

Foslie and Printz, 1929, K. norske vidensk. selsk. Museet. Mon., p. 30 pls. $48,52$.
Taylor, 1950, Mich. Univ. Studies, Sci. ser., v. 18, p. 123-124, pls. 58-60.

Johnson, 1954, U.S. Geol. Survey Prof. Paper 260-M, p. 541, pl. 195, figs. 1-2.

Johnson, 1957, U.S. Geol. Survey Prof. Paper 280-E, p. 231 , pl. 59 , fig. 4 ; pl. 60 , fig. 3 .

Description.-Fragments of long rather irregular branches. Medullary hypothallus and the marginal perithallus well developed. Medullary hypothallus thick; in section consists of slightly to strongly curved rows of rectangular cells $23 \mu-32 \mu$ long and $12 \mu-18 \mu$ wide. Perithallus composed of rows of cells that are fairly regular except around groups of megacells; cells measure $12 \mu-22 \mu$ long and $12 \mu-18 \mu$ wide; megacells $20 \mu-31 \mu$ in diameter, normally little longer or little shorter than wide. No conceptacles observed.

Remarks.-Foslie described this species originally from specimens collected on the Recent reefs at Funafuti. This species is most abundantly represented form recognized in the Funafuti cores. It also occurs in appreciable abundance on the Recent reefs and in surface and near-surface material at Eniwetok. It grows on corals and as small clusters of branches on the bottom in the more protected areas of the reef flat behind the algal ridge.

Age: Recent and Pleistocene.

Locality: Funafuti, on the Recent reefs and in the main drill hole down to depths of $950 \mathrm{ft}$; Eniwetok, Recent reefs and in $\mathrm{K}-1$ from surface to depth of about $40 \mathrm{ft}$.

\section{Goniolithon myriocarpon Foslie}

Plate 275, figure 6

Goniolithon myriocarpon Foslie, 1904, Wiss. Meers., N. F. B. 7, abt. Helgoland, Heft 1, p. 23.

Weber van Bosse and Foslie, 1904, Siboga-Expeditie Mon. 61 , p. 45 , pl. 9 , fig. 6 .

Foslie, 1909, K. norske vidensk. selsk. Skr., no. 2, p. 9.

Description.-Thallus a thin crust. Hypothallus thin, poorly coaxial, or curved rows of cells. Cells $16 \mu-$ $20 \mu$ long, $12 \mu-16 \mu$ wide. Perithallus moderately to well developed, cells $9 \mu-15 \mu$ long, $9 \mu-11 \mu$ wide. Megacells abundant in most area of perithallic tissue; $26 \mu-29 \mu$ high and $16 \mu-21 \mu$ wide. No conceptacles present.

Remarks.-In growth habit and cell dimensions the Eniwetok specimens agree with Foslie's descriptions of this widely distributed Recent species.

Age: Recent and Miocene.

Locality: F-1, Eniwetok 1,232-1,248 ft (core).

Figured specimen: F-1-3-3 (1), USNM 40820.

\section{Goniolithon fosliei (Heydrich) Foslie}

Plate 275, figure 7

Lithothamnion fosliei Heydrich, 1897, Deutsche, bot. Gesell., Ber. p. 15, 58.

Lithophyllum fosliei Heydrich, 1897, Deutsche bot. Gesell., Ber. p. 15, 140. 
Goniolithon fosliei (Heydrich) Foslie, Weber van Bosse and and Foslie, 1904, Siboga-Expeditie, Mon. 61, p. 46-48, pl. 9, figs. 1-5.

Foslie and Printz, 1929, K. norske vidensk. selsk. Museet, Mon., p. 29, pl. 46, figs. 1-5.

Description.-Thallus a crust; superimposed thalli may form crustose masses over a centimeter thick. Thallus consists of well-developed coaxial hypothallus overlain by a perithallus that may be slightly or strongly developed. Hypothallic cells $20 \mu-38 \mu$ by $7 \mu-11 \mu$; perithallic cells $12 \mu-20 \mu$ by $8 \mu-10 \mu$. Megacells rare in some specimens, fairly abundant in others, commonly 3 to 5 in a vertical row. Conceptacles wide and low, $800 \mu-1,000 \mu$ in diameter.

Remarks.-This Recent species widely distributed over Indian Ocean and tropical Pacific. According to Foslie (1904) and Lignac-Grutterink (1943, p. 291), there is considerable range in cell dimensions in both same and in different specimens. Foslie, working only with Recent specimens, placed species in genus Goniolithon. Lignac-Grutterink, working with fossil material, considered it as a typical Lithophyllum.

A number of infertile fragments attributed to this species were observed in slides from the Funafuti cores.

Age: Recent and Pleistocene(?).

Locality: Funafuti, depth $526 \mathrm{ft}$.

Figured specimen: British Museum slide 665.

\section{Genus POROLITHON Foslie}

Description.-Porolithon resembles Lithophyllum in the structures of the hypothallus, perithallus, and conceptacles. It differs in having lenses of megacells in the perithallic tissue. These cells are much larger and commonly are more regularly arranged than the normal perithallic cells. A feature common to the genus is the presence of lateral pores connecting adjoining cells.

The genus contains both crustose and branching species. It occurs abundantly today in the tropical Pacific on and around the reefs. It is represented by a relatively small number of widely distributed species.

Members of this genus appear to develop most abundantly in relatively shallow well-circulated water. They are the most important builders of the algal ridge along the seaward margin of many reefs where their greatest development is from tide level down to 40 or 50 feet.

The genus is young, geologically. So far no specimens older than Pliocene have been found. Porolithon did not become abundant until the middle of the Pleistocene.

For convenience in classification the species are grouped into three divisions based on growth habit.

The following table shows the dimensions and distribution of the species studied.

Measurements (in microns) and distribution of species of Porolithon

\begin{tabular}{|c|c|c|c|c|c|c|c|c|c|c|c|c|}
\hline \multirow{2}{*}{ Species } & \multicolumn{2}{|c|}{$\begin{array}{l}\text { Hypothallus } \\
\text { cells }\end{array}$} & \multicolumn{2}{|c|}{ Perithallus cells } & \multicolumn{2}{|c|}{ Conceptacles } & \multicolumn{3}{|c|}{ Megacells } & \multirow{2}{*}{ Locality } & \multirow{2}{*}{ Depth (feet) } & \multirow{2}{*}{ Age } \\
\hline & Length & Width & Length & Width & Diameter & Helght & Diameter & Height & $\begin{array}{l}\text { Number } \\
\text { in cluster }\end{array}$ & & & \\
\hline \multicolumn{13}{|c|}{ Division 1.-Crusts } \\
\hline $\begin{array}{l}\text { Porolithon onkodes (Heyd- } \\
\text { rich) Foslie. }\end{array}$ & & & $6-12(20)$ & $7-12$ & $125-175$ & $60-78$ & $8-17$ & $17-34$ & $5-10$ & 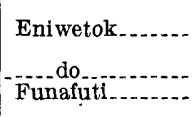 & $\mid \begin{array}{l}\text { En-1, 30-50 } \\
\text { E-1, 10-30-... } \\
535 \text { and } 726 \ldots\end{array}$ & $\begin{array}{l}\text { Recent and late } \\
\text { Pleistocene(?). } \\
\text { Do. } \\
\text { Do. }\end{array}$ \\
\hline \multicolumn{13}{|c|}{ Division 2.-Large thick masses } \\
\hline $\begin{array}{l}\text { Porolithon craspedium } \\
\text { (Foslie) Foslie. }\end{array}$ & & & $9-14$ & $9-11$ & $200-270$ & $100-125$ & $13-18$ & $20-30$ & $7-12$ & $\begin{array}{l}\text { Funafuti...... } \\
\text { Eniwetok K-1... }\end{array}$ & $\begin{array}{l}\text { Recent reef } \\
70,110\end{array}$ & $\begin{array}{l}\text { Recent and Pleis- } \\
\text { tocene(?). } \\
\text { Do. } \\
\text { Do. }\end{array}$ \\
\hline
\end{tabular}




\section{Division 1-Crusts \\ Porolithon onkodes (Heydrich) Foslie}

Lithothamnion onkodes Heydrich, 1897, Deutsche bot. Gesell. Ber., v. 15, p. 410.

Porolithon onkodes (Heydrich) Foslie. Taylor, 1950, Mich. Univ. Studies, Sci. ser., v. 18, p. 125, pls. 9, 61-63.

Johnson, 1957, U.S. Geol. Survey Prof. Paper 280-E, p. 232-233, pl. 55, figs. 6,7 ; pl. 59, fig. 6 .

Description.-Plant encrusting. Hypothallus thin, consisting of few layers of horizontally elongated cells. Perithallus tissue composed of rectangular cells $6 \mu-12 \mu$ $(20 \mu)$ by $7 \mu-12 \mu$ arranged in vertical rows and poorly defined horizontal layers. Lenses of megacells occur at irregular intervals in perithallic tissue. In section they occur in clusters, commonly of 5 to 10 . Megacells $17 \mu-34 \mu$ long, $8 \mu-17 \mu$ wide. Conceptacle chambers $125 \mu-175 \mu$ in diameter, $60 \mu-78 \mu$ high.

Remarks.-Fairly abundant in some near-surface samples. Specimens correspond with Recent material collected at Bikini Atoll.

Age: Recent and Pleistocene(?).

Locality: Eniwetok, Engebi Island, En-1, 30-50 ft; Parry Island E-1, depth 10-30 ft. Funafuti, main boring, 535 and $726 \mathrm{ft}$.

\section{Division 2- Large thick masses}

\section{Porolithon craspedium (Foslie) Foslie}

Lithophyllum craspedium Foslie, 1900, K. norske vidensk. selsk. Skr., no. 5, p. $26,27$.

Porolithon craspedium (Foslie) Foslie. Taylor, 1950, Mich. Univ. Studies, Sci. ser., v. 18, p. 126-128, pls. 64-65.

Johnson, 1954, U.S. Geol. Survey Prof. Paper 260-M, p. 541, pl. 193.

Johnson, 1957, U.S. Geol. Survey Prof. Paper 280-F, p. 232, pl. 56, figs. 4, 5 ; pl. 59, figs. 1-3.

Description.-Plant forms dense cushion-shaped masses with knobby or coarse fingerlike protuberances. Medullary hypothallus and marginal perithallus not sharply defined. Cells in rows and fairly distinct layers; perithallic cells $9 \mu-14 \mu$ by $9 \mu-11 \mu$. Lenses of megacells abundant, which show a great range in size; the more conspicuous measure $20 \mu-30 \mu$ high, $13 \mu-18 \mu$ wide; commonly they are in clusters of 7 to 12 . Conceptacle chambers $200 \mu-270 \mu$ in diameter, $100 \mu-125 \mu$ high.

Remarks.--A number of fragments were observed, all of which closely resemble Recent material collected at Bikini Atoll. Recent species grows in and just below the surf zone-particularly on lee side of reefs.

Age: Recent and Pleistocene(?).

Locality: Eniwetok $\mathrm{K}-1$, depths $70-110 \mathrm{ft}$; Engebi Island, slides K-1-2 (2), K-1-2 (1) ; Funafuti, depth $40-70 \mathrm{ft}$.
Division 3-Strongly branching forms

Porolithon aequinoctiale (Foslie) Foslie

Plate 275, figures 1, 2

Lithophyllum aequinoctiale Foslie, 1909, K. norske vidensk. selsk. Skr., no. 2 , p. 46.

Porolithon aequinoctiale (Foslie) Foslie. Taylor, 1950, Mich. Univ. Studies, Sci. ser., v. 18, p. 132, pls. 68, 70.

Description.-Plants form masses of short wide branches. Eniwetok material consists of worn fragments mainly of perithallic tissue; perithallic cells $12 \mu$ $18 \mu$ by $9 \mu-13 \mu$. Lenses of megacells abundant, showing as horizontal rows in section, commonly 7 to 9 in a row, but there may be many more. Megacells $27 \mu$ $41 \mu$ high and $11 \mu-18 \mu$ wide. Conceptacle chambers $135 \mu-216 \mu$ in diameter, $72 \mu-108 \mu$ high.

Remarks.-Eniwetok fragments attributed to this species largely on basis of abundance and size of megacells and size of conceptacle chambers. Perithallic cells fall within size range but average a little wider.

Species grows in shallow water on outer-reef platform and in lagoons.

Age: Recent and Pleistocene(?).

Locality: Eniwetok E-1, depth 50-60 ft. (cuttings) and En$6,35 \mathrm{ft}$.

Figured specimens: En-6-29-2, USNM 40818; En-6-29-1, 40817.

\section{Porolithon gardineri (Foslie) Foslie}

Lithophyllum gardineri Foslie, 1907, K. norske vidensk. selsk. Skr., no. 8, p. 30.

Foslie, 1907, Linnean Soc. London Trans., ser. 2, Zoology, v. 12, pt. 2, p. 190.

Lithophyllum (Porolithon) gardineri Foslie, 1909, K. norske vidensk. selsk. Skr., no. 2, p. 44-45.

Porolithon gardineri (Foslie) Foslie. Taylor, 1950, Mich. Univ. Studies, Sci. ser., v. 18, p. 129-131, pls. 5-9; pl. 70, fig. 1 ; pls. 71-73; pl. 76, fig. 2 , pl. 77.

Description.-Plants cushion shaped, as much as 30 $\mathrm{cm}$ in diameter and $20 \mathrm{~cm}$ high. Basal part crustose with long branches forming densely packed rounded heads. In section, heads show a regularly arranged medullary hypothallus with cells $9 \mu-30 \mu$ long, $9 \mu-13 \mu$ wide. Marginal perithallus moderately thick, rather loose texture, cells $8 \mu-19 \mu$ long and $9 \mu-11 \mu$ wide, arranged in radial rows but not in distinct layers. Megacells abundant in perithallic tissue, in clusters of 8 to more than 20 , commonly 4 to 6 in a section. They measure $28 \mu-35 \mu$ high and $9 \mu-18 \mu$ wide. Conceptacles $110 \mu-152 \mu$ in diameter and $68 \mu-110 \mu$ high.

Remarks.-This Recent species is one of common forms in the algal ridge of many atolls. It was observed in a number of slides from Funafuti drilling.

Age: Recent and Pleistocene (?).

Locality: Recent species widespread in Red Sea, Indian Ocean, and tropical Pacific. Fossil material observed in Funafuti core at depths of 10-30 ft. and 547-555 ft. 


\section{Porolithon marshallense Taylor}

Plate 275, figures 3, 4

Porolithon marshallense Taylor, 1950, Mich, Univ. Studies Sci. ser., v. 18, p. 128-129, pls. 67 and 76.

Johnson, 1954, U.S. Geol. Survey Prof. Paper 260-M, p. 542, pl. 197, fig. 1.

Description.-Plant compact mass of branches, each consisting of wide medullary hypothallus surrounded by relatively narrow marginal perithallus. Cells of hypothallus $14 \mu-23 \mu$ by $9 \mu-14 \mu$, commonly about $16 \mu$ by $10 \mu$. Perithallic cells $10 \mu-14 \mu(20 \mu)$ by $8 \mu-11 \mu$, commonly about $12 \mu$ by $10 \mu$. Megacells commonly 8 to 12 in cluster, size $25 \mu-45 \mu$ by $11 \mu-18 \mu$, average $36 \mu$ by $12 \mu$. Conceptacles $135 \mu-144 \mu$ in diameter, $81 \mu-90 \mu$ high.

Remarks.-This species closely fits 'Taylor's description in cell size and in having cells arranged in distinct layers. Few conceptacle chambers observed, somewhat smaller than in type material. It differs from $P$. gardineri in having larger megacells, and in having distinct layers of cells. Recent species frequently grow in surf zone, slightly behind outer edge of reefs.

\section{Age: Recent.}

Locality: Eniwetok E-1, depths 30-35 and 60-70 ft (cuttings). Figured specimens: E-1 60-70 USNM 40819: E-1-30-35, USNM 40940.

\section{Genus PARAPOROLITHON Johnson, 1957}

The hypothallus and conceptacles are of the Lithophyllum type. The distinctive feature is that the perithallic tissue not only contains small lenticular clusters of large megacells such as characterize the genus Porolithon, but it also contains numerous smaller megacells which occur singly or in vertical groups as in Goniolithon. This genus is known only from the Miocene.

\section{Paraporolithon saipanense Johnson}

Paraporolithon saipanense Johnson, 1957, U.S. Geol. Survey Prof. Paper 280-E, p. 233, pl. 52, figs. 4, 5.

Description.-Thallus a warty crust $0.8-1.4 \mathrm{~mm}$ thick. Hypothallus poorly coaxial $75 \mu-225 \mu$ thick, composed of rectangular cells $12 \mu-25 \mu$ long and $11 \mu-$ $15 \mu$ wide, averaging $13 \mu$ by $11 \mu$. Perithallus of fairly regular rows of cells $13 \mu-17 \mu$ by $11 \mu-15 \mu$. Partitions between cell rows clearly developed; lenses of large megacells sparingly distributed through tissue. Sections through these show 4 to 8 cells to a cluster, averaging 5; megacells measure $46 \mu-68 \mu$ high and $15 \mu-18 \mu$ wide. Smaller megacells, $15 \mu-18 \mu$ by $14 \mu-18 \mu$ scattered abundantly throughout tissue, singly or in pairs. No conceptacles present.

Remarks.-Only one fragment of this species was observed in the Kita-Daitō-Jima slides. In appearance and cell measurements it agrees with the specimen described from Saipan.

Age: Miocene.

Locality: Kita-Daitō-Jima core, depth $646 \mathrm{ft}(197 \mathrm{~m})$.

Specimen: Tōhoku Univerity colln., slide 876.

\section{Genus LITHOPORELLA Foslie, 1909}

Weber van Bosse, A., and Foslie, M. H., 1904. The Corallinaceae of the Siboga Expedition. Mon. 61,110 pp., 16 pls.

Foslie, M. H.. 1909. Algologiske Notiser VI. K. norske vidensk. selsk. Skr., no. 2, p. 1-63.

Lemoine, Mme. Paul, 1917. In F. Borgesen. Rhodophyta of the Danish West Indies. Dansk. Bot. Ark., v. 3, no. 1, p. $147-200$.

Howe, M. A., 1919. Tertiary calcareous algae from the islands of St. Bartholomew, Antigua, and Angiulla. Carnegie Inst. Washington Pub. 291, p. 9-20, pls. 1-6.

Setchell, IV. A., 1943. Mastorphora and the Mastophoreae: Genus and subfamily of Corallinaceae. Natl. Acad. Sci. Proc. v. 29, no. 5, p. 127-135.

Ishijima, W., 1954. Cenozoic coralline algae from the western Pacific: Private publ., Tokyo, Japan, 87 p., 49 pls.

The identification of thin crustose coralline algae whose thalli are built of one or only a few layers of cells is extremely difficult and unless conceptacles are present, specific identification is impossible.

The term Lithoporella was used by Foslie in 1904 (Weber van Bosse and Foslie, p. 73) as a subgenus under Mastophora, with Mastophora melobesioides Foslie as its type. Later Foslie (1909, p. 59) raised Lithoporella to full generic rank. This was accepted by American geologists without question for about 10 years. Marshall A. Howe in 1919 (p. 17) states, "Foslie's establishment of a genus Lithoporella to receive the monostromatic calcified forms that he had previously referred to Mastophora seems justified." However, a year or two earlier, Mme. Lemoine (1917, p. 174), apparently as a result of studies of modern algae from the West Indies, preferred to consider Lithoporella a subgenus under Melobesia. In recent years, American geologists have tended to follow Howe's example and consider Lithoporella as an independent genus, while most European geologists and botanists have followed Mme. Lemoine.

Lithoporella has very thin monostromatic crustose thalli except around the conceptacles. The cells are rectangular, vertically elongated, and form a palisadelike layer. Rhizoids are absent. The thalli commonly grow superimposed or alternating with other crustose algae or encrusting Foraminifera to form thick crusts. Conceptacles are large, with a single aperture.

Lithoporella closely resembles Mastophora Decaisne, but Mastophora has long rhizoids for attachment, and normally the thalli do not grow superimposed. Another closely related genus is Heteroderma Foslie which 
differs from Lithoporella in consisting of 1 or 2 layers of isodiametric cells which are not vertically elongated to form palisadelike layers. Adjacent thalli become confluent but never superimposed. Melobesia Lamouroux differs from Lithoporella by having horizontally elongated cells in the basal layer; the thallus may be several layers thick, and the conceptacles have a number of openings.

Lithoporella ranges from Eocene to Recent. In exist- ing seas it is abundantly represented by a few widespread species. They grow on almost any sort of hard object and have been found attached to noncalcareous algae. They live from tide level to at least 50 meters. A number of Recent and fossil species have been named. All show a wide range of cell sizes, even in a single specimen.

The following table shows the measurements and distribution of species studied.

Measurements (in microns) and distribution of species of Lithoporella

\begin{tabular}{|c|c|c|c|c|c|c|c|}
\hline \multirow{2}{*}{ Species } & \multicolumn{2}{|c|}{ Cell dimensions } & \multicolumn{2}{|c|}{ Conceptacles } & \multirow{2}{*}{ Locality } & \multirow{2}{*}{ Depth (feet) } & \multirow{2}{*}{ Age } \\
\hline & Length & Width & Diameter & Height & & & \\
\hline $\begin{array}{l}\text { Lithoporella melobesioides (Foslie) Foslie } \\
\text { cf. L. crassa Ishijima... } \\
\text { longicella Johnson n. sp. } \\
\text { antiquitas Johnson n. sp } \\
\text { sp. A } \\
\text { sp. B. B } \\
\text { sp. C. }\end{array}$ & $\begin{array}{r}34-45 \\
45-104 \\
30-60 \\
83-94 \\
23-46 \\
28-48\end{array}$ & $\begin{array}{r}13-23 \\
11-15 \\
9-15 \\
13-22 \\
43-59 \\
16-23 \\
20-31\end{array}$ & $\mid \begin{array}{r}175-250 \\
\end{array}$ & $\begin{array}{r}95-115 \\
-9 \\
-9\end{array}$ & $\begin{array}{l}\text { Funafuti, Recent reef cores } \\
\text { Kita-Daitō-Jima.. } \\
\text { Eniwetok } \\
\text { Eniwetok, K-1. } \\
\text { Eniwetok, E-1... } \\
\text { Eniwetok, E-1 } \\
\text { Eniwetok, F-1 } \\
\text { Eniwetok, F-1 } \\
\text { Kita-Daitō-Jima. }\end{array}$ & $\begin{array}{r}75-1,000 \\
0-333 \\
350 \\
260-270 \\
2,003-2,028 \\
2,675 \\
1,718-1,740 \\
380\end{array}$ & $\begin{array}{l}\text { Pleistocene or Recent. } \\
\text { Pleistocene. } \\
\text { Eocene to Recent. } \\
\text { Recent or Pleistocene(?). } \\
\text { Pleistocene(?). } \\
\text { Miocene. } \\
\text { Lower Miocene. } \\
\text { Upper Miocene. } \\
\text { Pliocene-Pleistocene. }\end{array}$ \\
\hline
\end{tabular}

Lithoporella melobesioides (Foslie) Foslie

Mastophora melobesioides Foslie, 1903, K. norske vidensk. selsk. Aarsber. 1902.

Mastophora (Lithoporella) melobesioides Fostie. Weber van Bosse and Foslie, 1904, siboga-Expeditie Mon. 61, p. 7375 , figs. 30-32.

Foslie, 1908, Alg. Nat. 5, K. norske vidensk, selsk, Skr., no. 7 , p. 19.

Lithoporella melobesioides (Foslie) Foslie. Foslie, 1909, Alg. Nat. 6, norske vidensk. selsk. Skr., 1909 , no. 2, p. 58, 59 .

Howe, 1918, U.S. Natl. Mus. Bull 103, p. 11.

Howe, 1919, Carnegie Inst. Washington Pub 291, p. 16-19, pl. 6.

Mastophora melobesioides Foslie. Pfender, 1926, Soc. española historia nat. Bol., v. 26, p. 327-328, pl. 15.

Melobesia (Lithoporella) melobesioides Foslie. Lemoine, 1928 (a). Mus. nat. histoire nat., Bull. 1927, p. 550.

Lemoine, 1928 (b). Inst. Catalonia Hist. Nat. Bull., ser. 2, v. 8, no. 5-6, p. 104.

Airoldi, 1931. R. Acc. dei Lincee, Rend. v. 13, 5-6, 5 ann. 1, pt. $6-7$, p. $533-34$.

Airoldi, 1932. Paleontographica Italica, v. 33, p. 81, pl. 12, fig. 5 .

Miranda, 1935. Soc. española historia nat. Bol. v. 30, p. 285.

Lemoine, 1938. Soc. Géol. France, Compte rendu, pt. 7, p. 123 (Apr. 4, 1938).

Lemoine, 1939. Mat. Carte Geol. de l'Algerie, Mem. 9, p. 108-110, fig. 79.

Conti, 1943. Palaeontographia Italica, v. 41, p. 60.

Lithoporella melobesioides (Foslie) Foslie. Lignac-Gruttirink, 1943. Geol.-nijnb. genootsch. Nederland en Kolonien Verh., Geol. ser., v. 113, p. 292, pl. 2, fig. 8.

Lithoporella (Melobesia) melobesioides (Foslie) Foslie. Johnson and Ferris, 1949, Jour. Paleontology, v. 23, no. 2, p. 196, pl. 39, figs. 1-2.

Lithoporella melobesioides (Foslie) Foslie. Johnson and Ferris, 1950, B. P. Bishop Mus. Bull. 201, p. 18, pl. 8, fig. A.
Melobesia (Lithoporella) melobesioides Foslie. Conti, 1950. Pub. Inst. Geol., Univ. Genoa Quad. 4, p. 130.

Mastrorilli, 1950. Atti. Inst. Geol. Univ. Pavia, v. 4, p. $65-66$.

Lithoporella melobesioides (Foslie) Foslie. Johnson and Tafur, 1952. Jour. Paleontology, v. 26, no. 4, p. 541-542, pl. 62, fig. 2, pl. 64, fig. 1 .

Ishijima, 1954. Cenozoic coralline algae from the western Pacific, p. 47-48, pl. 45, figs. 1-6, pl. 46, fig. 1 .

Johnson, 1954. U.S. Geol. Survey Prof. Paper 260-M, p. 542-543, pl. 197, figs. 2-3.

Johnson, 1957. USGS Prof. Paper 280-E, p. 234, pl. 37. fig. 5 , pl. 43 , figs. 1,2 , pl. 49 , fig. 4 , pl. 56, fig. 6 .

Description.-Thallus thin irregular crusts that consist of single layer of large vertically elongated rectangular cells; around conceptacles few additional layers of small cells may develop. Cell walls thick, showing great range in size even in same plant. Cells measure $25 \mu-76 \mu$ long and $13 \mu-23 \mu$ wide. Conceptacle chambers $250 \mu-485 \mu$ in diameter and $38 \mu-158 \mu$ in height.

Remarks.-Fossils attributed to this species were found abundantly in all material studied from Funafuti, Kita-Daitō-Jima, and Eniwetok.

Age: Eocene to Recent.

Lithoporella cf. L. crassa Ishijima

Plate 276, figure 6

Lithoporella crassa Ishijima, 1945, Cenozoic coralline algae western Pacific, p. 50, pl. 48, fiǵs. 1-3; pl. 49, figs. 1-3.

Description.-Thallus a single layer of vertically elongated cells in palisadelike rows; cells $34 \mu-45 \mu$ high and $11 \mu-15 \mu$ wide with thick walls. Numerous thalli 
grow superimposed to form thick crusts. No conceptacles observed.

Remarks.-Represented by several infertile fragments. These closely resemble the material recently described by Ishijima from the Pleistocene of Formosa. In section they suggest Lithophyllum megacrustum Johnson and Ferris (1950) from the Pleistocene of Fiji but differ in the more irregular arrangement of the cell layers, which are interpreted as individual thalli. Without a knowledge of the conceptacles it seems wise only to indicate their resemblance to Lithoporella crassa.

Age: Recent or Pleistocene(?).

Locality: Eniwetok hole $\mathrm{K}-1$, depth about $350 \mathrm{ft}$ (cuttings). Figured specimen: K-1-30-1, USNM 40821.

Lithoporella longicella Johnson, n. sp.

Plate 276, figures 3, 4

Description.-Thallus a single layer of long narrow palisade cells, which show a considerable range in size in a single thallus. Thalli may be irregular; numerous thalli growing superimposed to form thick nodular masses. Cells measure $45 \mu-104 \mu$ high and $9 \mu-15 \mu$ wide (commonly $70 \mu$ by $12 \mu$ ). Cell walls distinct but not as thick as many species of the genus. Conceptacles unknown.

Remarks.-This species is closely related to Ishijima's species $L$. australis and L. crassa but has longer cells with thinner cell walls and in being strictly monostromatic.

Age: Recent or Pleistocene(?).

Locality: Eniwetok E-1, depth 260-270 ft (cuttings).

Figured specimen: Holotype, USNM 40822.

Lithoporella antiquitas Johnson, n. sp.

Plate 276, figures 1, 2

Description.-Thallus a single layer of vertically elongated cells $30 \mu-60 \mu$ long and $13 \mu-22 \mu(28 \mu)$ wide. Conceptacles small, $175 \mu$ by $95 \mu$, to $250 \mu$ by $115 \mu$. One shows an aperture with a neck about $40 \mu$ wide and $260 \mu$ long.

Remarks.-Cell size of this species within great size range of Lithoporella melobesioides, but below average size. Conceptacles of $L$. melobesioides measure $600 \mu-$ $1,000 \mu$ in diameter, those of L. antiquitas smaller. Because type slide of $L$. antiquitas shows aperture clearly, including exit tube, without doubt it cuts conceptacle across center and shows maximum diameter.

Age: Miocene.

Locality: Eniwetok E-1, depth 2,003 and 2,028 ft (cores).

Figured specimen: E-1-1-4(1) large. Holotype USNM 40825.

\section{Lithoporella sp. A}

Plate 277, figure 14

Description.-Several fragments of Lithoporella in Miocene section showed large cells measuring $83 \mu-94 \mu$ by $43 \mu-59 \mu$. These cells larger and much wider than most members of genus and probably represent an undescribed species; without knowledge of conceptacles it does not seem wise to name it.

Age: Miocene.

Locality: Eniwetok hole F-1, depth $2,675 \mathrm{ft}$ (core).

Figured specimen: F-1-6-25 (2), USNM 40823.

\section{Lithoporella sp. B}

Plate 276, figure 5

Description.-Thallus a single layer of vertically elongated rectangular cells $23 \mu-46 \mu$ high and $16 \mu-23 \mu$ wide. Conceptacles unknown.

Remarks.-Represented by several infertile specimens.

Age: Miocene.

Locality: Eniwetok F-1, depth 1,718-1,740 ft (core).

Figured specimens: $\mathrm{F}-1-4-10$ (2) and F-1-4-20, USNM 40824.

Lithoporella sp. C

Description.-Thallus monostromatic except around conceptacles. Cells elongated, often obliquely. Cells shown an appreciable range in size, as indicated below. Conceptacles unknown.

$\begin{array}{cccc}\text { Cell } & & \\ \text { Slide } & \begin{array}{c}\text { dimensions } \\ \text { No. }\end{array} & \text { Conceptacles } & \text { Age } \\ 661(1) & 32-44 \text { by } 20-31 & \text { Absent_-_-- } & \text { Pliocene-Pleistocene } \\ 661(2) & 28-34 \text { by } 25-28 & -\ldots \text { do_---- } & \text { Do. } \\ 661(2) & 34-48 \text { by } 22-24 & \text {-_-_do_---- } & \text { Do. }\end{array}$

Remarks.-If the ratio of cell width and length is a basis for species differentiation in this genus, then this material belongs to different species than preceding ones. However it does not seem wise to give it a name without knowledge of conceptacles.

Locality: Kita-Daitō-Jima core, depth $115 \mathrm{~m}$ ( $380 \mathrm{ft}$ ).

Age: Pliocene-Pleistocene.

Specimen: Tōhoku University colln., slide 661.

\section{Genus DERMATOLITHON Foslie, 1899}

Algae in this genus develop small thin crusts characterized by a hypothallus formed of a single layer of large, obliquely elongated cells that may be contorted. The perithallus is formed of several to many layers of rectangular cells. The conceptacles are hemispherical to conical with a single aperture.

The genus is widely distributed today in tropical and temperate waters. The numerous species are commonly epiphytic but may grow, attached to shells, pebbles, and other objects. They are characteristic of the littoral 
zone, commonly just below low tide level but reaching to depths of as much as 80 meters.

Dermatolithon marshallensum Johnson, n. sp.

Plate 277, figure 13

Description.-Thallus normally monostromatic, consisting of single hypothallic layer. Cells obliquely elongated, measuring $40 \mu-63 \mu$ high and $18 \mu-27 \mu$ wide. Conceptacle hemispheric, $300 \mu$ in diameter and $125 \mu$ high.

Remarks.-D. marshallensum differs from D. saipanensum. Johnson from the Miocene of Saipan in having shorter hypothallic cells, smaller conceptacles, and in lacking the well-developed perithallus found in $D$. saipanensum. It differs from the widely distributed Recent species D. papitlosum (Zanardini) Foslie in having wider hypothallic cells and developing more regular thallus.

Age: Miocene.

Locality: Eniwetok F-1, depth 1,725-1,985 ft (cores).

Figured specimen: F-1-5-18(3). Holotype USNM 40826.

Subfamily CORALIINOIDEAE (articulate corallines)

Fragments of articulate coralline algae were found in considerable numbers in the Eniwetok drill samples but were comparatively rare in the material from Funafuti and Kita-Daitō-Jima. In a few instances 2 or 3 segments were found connected by nodes but the majority of the fossils consist of single segments. The identification of such fragments is difficult, if not impossible, because many living species have been discriminated by using such features as size and shape of the plant or its fronds, character of the branching, or other features that cannot be recognized in fragments. The size, shape, and position of the conceptacles have also been used in separating Recent species. Because conceptacles are normally external and seldom are calcified, they are of little use in identifying fossils.

Attempts have been made to use features that can be determined from segments. These include: (a) The size and shape of the segments, (b) the dimensions of the cells along the axis of the frond, (c) the number of rows of cells in a segment, and (d) the range in size of cells. The first feature-listed above is useful in separating genera but is of questionable value in separating species because in a number of Recent species, the segments from different parts of the plant are known to differ considerably in size and shape and in the number of cell rows that form the segments. Measurements of the length of the cells along the axis also show appreciable variation, but it may be that for a given species the cell dimensions will fall within certain limits and thus be useful in characterizing the species. Such, indeed, is the case among the crustose corallines, but sufficient work has not yet been done with the articulate forms to decide the question. The author has, therefore, been reluctant to attach specific names to fossil articulates except where large numbers of specimens, including those showing joined segments, were available for study.

Representatives of three genera were found in the collections studied. Corallina and Amphiroa were the most abundant, with a few examples of Jania.

\section{Genus JANIA Lamouroux, 1812}

The plants consist of masses of slender dichotomously branching fronds arising from an inconspicuous disc. Each frond consists of a series of slender segments formed of tiers of hypothallic cells surrounded by a narrow perithallus, which is characteristically restricted to a single layer of small rectangular cells. The hypothallic cells tend to be wider in proportion to length than in most genera of articulate corallines. In many instances, they appear wedge shaped in section. Conceptacles usually occur singly in swollen terminal segments of branches.

Today this genus is widespread in the tropic and temperate seas where it is represented by many species. At least three species grow on the reefs at Eniwetok. The plants are fairly abundant locally on the undersides of rocks and in shallow pools on the reef flat. Fossil representatives are known from rocks as old as Late Cretaceous.

Jania miocenica Johnson n. sp.

Plate 278, figures $6,7,8$

Description.-Slender segments with dimensions (in microns) as follows.

\begin{tabular}{|c|c|c|c|c|c|c|c|}
\hline \multirow{3}{*}{ Slide } & \multirow{3}{*}{$\begin{array}{c}\text { Size } \\
\text { segment }\end{array}$} & \multirow{3}{*}{$\begin{array}{l}\text { Number } \\
\text { of cell } \\
\text { rows in } \\
\text { segment }\end{array}$} & \multirow{3}{*}{$\begin{array}{l}\text { Number } \\
\text { of cells } \\
\text { in a } \\
\text { row }\end{array}$} & \multicolumn{4}{|c|}{ Cells } \\
\hline & & & & \multirow{2}{*}{$\begin{array}{l}\text { Medul- } \\
\text { lary, } \\
\text { length }\end{array}$} & \multirow{2}{*}{$\begin{array}{l}\text { Hypo- } \\
\text { thallus, } \\
\text { width }\end{array}$} & \multicolumn{2}{|c|}{ Perithallic } \\
\hline & & & & & & Length & Width \\
\hline$F-1-4-8(2) \ldots$ & $1.0 \times 0.36$ & & & & & & \\
\hline $\mathrm{F}-1-4-10(2)$ & $\begin{array}{l}1.0 \times .25 \\
1.5 \times .3\end{array}$ & $\begin{array}{l}20 \\
43 \\
\end{array}$ & $\begin{array}{l}16-18 \\
18-21\end{array}$ & $\begin{array}{l}38-47 \\
31-47\end{array}$ & $\begin{array}{l}13-15 \\
12-16\end{array}$ & (1) & (1) \\
\hline $\mathrm{F}-1-5-2(2)$ & $11 \times 25$ & $17+$ & 2022 & $41-47$ & $12-15$ & $10-13$ & $11-16$ \\
\hline $\begin{array}{l}F-1-5-18(3) \\
F-1-5-10(3)\end{array}$ & $\begin{array}{l}1.1 \times .25 \\
1.7 \times .33\end{array}$ & $\begin{array}{l}24 \\
31\end{array}$ & $\begin{array}{c}18-22 \\
16+\end{array}$ & $\begin{array}{l}32-41 \\
41-47\end{array}$ & $\begin{array}{l}16-19 \\
17-23\end{array}$ & & \\
\hline $\mathrm{F}-1-5-1(1)$ & $1.3 \times 3$ & $26+$ & 13 & $37-46$ & $16-23$ & $19-28$ & $21-28$ \\
\hline
\end{tabular}

1 Absent.

A conceptacle chamber is shown on one specimen; it measures approximately $350 \mu$ in length and $100 \mu$ in width (pl. 278, fig. 8).

Remarks.-Numerous fragments were observed. Specimen showing conceptacle chamber believed to be first of Miocene age to be found. 
Age: Miocene.

Locality: Eniwetok F-1, depth 1,718-1,980 ft (cores).

Figured specimen: F-1-4-8 (2), holotype USNM 40919; F-1-1-10 (2), USNM 40918.

\section{Jania vetus Johnson}

Jania vetus Johnson, 1957. U.S. Geol. Survey Prof. Paper 280-E, p. 237, pl. 52, fig. 2.

Remarks.-Several well-preserved segments belonging to this species found in one of Eniwetok cores. Age: Miocene.

Locality: Eniwetok F-1, depth 1,232-1,248 ft (core).

Jania sp. A

Plate 278, figure 4

Description.-Long regular cylindrical segments about 2.0 by $0.37 \mathrm{~mm}$. Segment contains 28 to 30 tiers of cells, 17 to 21 cells to a row. Hypothallic cells $59 \mu-$ $73 \mu$ long, $16 \mu-20 \mu$ wide. Marginal cells $23 \mu-28 \mu$ long, $14 \mu-18 \mu$ wide.

Remarks.-Several well-preserved segments and pieces of segments found in the Eocene limestones of Eniwetok.

Age: Late Eocene.

Locality: Eniwetok F-1, depth 4,320-4,340 ft (core).

Figured specimen: F-1-12-4(1) bottom, large, USNM 40916.

Genus AMPHIROA Lamouroux, 1812

Plants develop from a small basal disk. They consist of clusters of segmented fronds that branch dichotomously or trichotomously at regular intervals. Fronds formed of calcified segments alternating with uncalcified nodes. Segments cylindrical to flattened, in some cases having a thick midrib and thinner margins. Each segment contains a well-developed medullary hypothallus. In most Recent and Pleistocene species, the hypothallus is built of alternating tiers of long and short cells. Older species may have hypothalli with tiers of cells of equal or nearly equal length. The marginal perithallus is moderately well developed, built of layers of small rectangular cells. Conceptacles are lateral, more or less imbedded in the perithallic tissue, often projecting above the outer surface.

This genus occurs abundantly in the warm seas of today. Fossils are known from rocks as old as Late Cretaceous. A considerable number of fragments were observed in the Eniwetok material.

Amphiroa fortis Johnson, n. sp.

Plate 277, figures 8,9

Description.-Segments $0.9-4.0 \mathrm{~mm}$ long and 0.3-0.75 $\mathrm{mm}$ wide. Cell rows of medullary hypothallus regularly arranged with tendency to alternation of length after the formula-3 long, 1 short. Cell lengths $63 \mu-$ $71 \mu$ in the long rows, and $59 \mu-63 \mu$ in the short rows.
Cell widths $6 \mu-11 \mu$. Marginal cells $15 \mu-21 \mu$ long and $7 \mu-11 \mu$ wide. No conceptacles observed.

Remarks.-This species abundantly represented in core F-1-11. Characterized by the regularity of its cell rows and the length of their cells.

Age: Late Eocene.

Locality: Eniwetok F-1, depth 4,197-4,222 ft (core).

Figured specimens: F-1-11-1, holotype USNM 40834; F-111-7, paratype USNM 40835.

\section{Amphiroa sp. A}

Plate 277, figure 6

Description.-Segments 1.8-2.5 mm long and 0.35$0.39 \mathrm{~mm}$ wide. Medullary hypothallus formed of layers of cells $54 \mu-81 \mu$ long and $11_{\mu-18} \mu$ wide. Cell layers tend to follow pattern of 2 layers of long cells alternating with 1 of short cells. Cells in long layers $58 \mu-80 \mu$ long, $11 \mu-16 \mu$ wide. Cells in short layers $54 \mu-65 \mu$ long, $11 \mu-14 \mu$ wide. Marginal cells missing. No conceptacles observed.

Remarks.-Represented by about a dozen specimens in slides from $\mathrm{F}-1-15$. This species has unusually long slender segments. Unfortunately, all are badly worn. Without a knowledge of marginal cells and conceptacles it does not seem desirable to give a specific name.

Age: Late Eocene.

Locality: Eniwetok F-1, depth approximately 4,540-4,550 ft (core).

Figured specimen: F-1-15-14, USNM 40945.

\section{Amphiroa sp. B}

Plate 277, figure 7

Description.-Segments composed of central hypothallus with layers of cells alternating -1 long and 1 short. Long cells $30 \mu-48 \mu$ long, $8 \mu-11 \mu$ wide; short cells $14 \mu-18 \mu$ long, $8 \mu-11 \mu$ wide. No marginal cells or conceptacles present.

Remarks.-Represented by two small badly worn fragments but of interest because of the pronounced and regular alternation of length of cell layers. This feature, while characteristic of most Recent and Pleistocene members of the genus, appears to be much less well developed in older species and is seldom noticeable in the early Tertiary forms seen by the writer.

Age: Late Eocene.

Locality: Eniwetok F-1, depth $4500-4525$ ft (core).

Figured specimen: F-1-14-8(2) large, USNM 40914.

\section{Amphiroa medians Johnson n. sp.}

Plate 278, figures 1, 2, 3

Description.-Fronds consist of segments $1.2-1.6 \mathrm{~mm}$ long and $0.45-0.66 \mathrm{~mm}$ thick. Conceptacles unknown. Dimensional data in microns are given in the following table. 


\begin{tabular}{|c|c|c|c|c|c|c|c|}
\hline \multirow{2}{*}{ Slide } & \multirow{2}{*}{$\begin{array}{l}\text { Size of } \\
\text { segment }\end{array}$} & \multirow{2}{*}{$\begin{array}{l}\text { Number of } \\
\text { cell rows in } \\
\text { segment }\end{array}$} & \multirow{2}{*}{$\begin{array}{l}\text { Number of } \\
\text { cells in a } \\
\text { row }\end{array}$} & \multirow{2}{*}{ Formula } & \multicolumn{2}{|c|}{ Medullary hypothallus } & \multirow{2}{*}{$\begin{array}{c}\text { Marginal } \\
\text { perithallus }\end{array}$} \\
\hline & & & & & Long cells & Short cells & \\
\hline $\begin{array}{l}\text { F-1-5-1(1L) } \\
\text { F-1-5-1 }(4 \mathrm{~L})\end{array}$ & $\begin{array}{l}1306 \times 608 \\
1250 \times 450 \\
1550 \times 540\end{array}$ & $\begin{array}{l}20 \\
17+ \\
31+\end{array}$ & $\begin{array}{l}27-31 \\
24-29 \\
37-40\end{array}$ & $\begin{array}{l}2-2,2-1 \\
1-1,2-1 \\
1-1,2-1\end{array}$ & $\begin{array}{l}63-71 \times 13-16 \\
66-76 \times 14-16 \\
52-62 \times 14-18\end{array}$ & $\begin{array}{l}53-63 \times 9-14 \\
63-65 \times 9-14 \\
47-55 \times 13-17\end{array}$ & $\begin{array}{l}17-26(34) \times 12-25 \\
\text { Worn off. } \\
\text { Worn off. }\end{array}$ \\
\hline
\end{tabular}

Remarks.-A number of specimens found in core F-1-5. Cell dimensions and relatively slight difference in length between long and short cells appear to be most distinctive characteristics of this species.

Age: Miocene.

Locality: Eniwetok F-1, depth 1,978-2,000 ft (core).

Figured specimen: F-1-5(1L), holotype USNM 40923; F-15(1L), USNM 40809; and F-1-5-1(4L), USNM 40915.
Amphiroa sp. C

Plate 278, figure 5

Description.-Segments about five times as long as wide. Cell layers of central hypothallus of nearly equal length but show tendency for slightly longer cells to alternate with shorter cells. Detailed dimensions in microns are given in the following table.

\begin{tabular}{|c|c|c|c|c|c|c|c|}
\hline \multirow{2}{*}{ Slide } & \multirow{2}{*}{$\begin{array}{l}\text { Size of } \\
\text { segment }\end{array}$} & \multirow{2}{*}{$\begin{array}{l}\text { Number } \\
\text { of cell } \\
\text { rows in } \\
\text { segment }\end{array}$} & \multirow{2}{*}{$\begin{array}{l}\text { Number } \\
\text { of cells in } \\
\text { a row }\end{array}$} & \multirow{2}{*}{ Formula } & \multicolumn{2}{|c|}{ Medullary hypothallus } & \multirow{2}{*}{$\underset{\text { perithallus }}{\text { Marginal }}$} \\
\hline & & & & & Long cells & Short cells & \\
\hline $\begin{array}{l}F-1-5-1(2) \\
F-1-5-3(1)\end{array}$ & $5.6 \times 1.2$ & $\begin{array}{l}34 \\
36\end{array}$ & $\begin{array}{l}16-22 \\
18-20\end{array}$ & $\begin{array}{l}1-1 \\
1-1\end{array}$ & $\begin{array}{l}48-60 \times 14-18 \\
48-58 \times 10-16\end{array}$ & $\begin{array}{l}45-56 \times 11-17 \\
40-55 \times 10-15\end{array}$ & 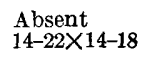 \\
\hline
\end{tabular}

Age: Miocene.

Locality: Eniwetok F-1, depth 1,797-2,003 ft (core).

Figured specimen: F-1-5-3(1) small, USNM 40917.

Genus CORaLIINa Linnaeus, 1758

The plants have a calcified crustose base from which arise numerous erect fronds that generally branch in a plane. The branching is commonly pinnate. The calcified segments are cylindrical or flattened, consisting of a medullary hypothallus surrounded by a thin cortical layer (perithallus). The medullary hypothallus consists of long narrow cells in layers of equal length. Nodes between the segments are normally not calcified. They are formed of a single layer of very long cells. Conceptacles are ovoid, terminal on short branches.

Corallina segments occur in considerable quantities at a number of levels in the Eniwetok drill holes. They represent a number of different species, several of which are described. Much of the material is too worn and frayed to permit specific identification.

Segments of articulate corallines attributed to this genus were observed in the loose and poorly consolidated material in the upper 70 feet of the main boring at Funafuti and in the upper 40 feet of the second boring. The material was not identified specifically.
Corallina prisca Johnson

Corallina prisca Johnson, 1957, U.S. Geol. Survey Prof. Paper 280-E, p. 239-240, pl. 37, fig. 4 , pl. 40 , fig. 10 , pl. 44 , figs. $1,2,7-11$.

Description.-Segments flattened to nearly cylindrical. Cells of medullary hypothallus in center of tiers $68 \mu-104 \mu$ long, $7 \mu-10 \mu$ wide. Perithallic cells $16 \mu-21 \mu$ long, $9 \mu-11 \mu$ wide. No conceptacles observed.

Remarks.-A number of fragments were observed in slides of the Eniwetok cores which in appearance and dimensions correspond to this species described from the Eocene of Saipan.

Age: Late Eocene.

Locality: Eniwetok F-1, depth 4,500-4,550 ft (core).

Corallina eniwetokensis Johnson n. sp.

Plate 277, figures $10,11,12$

Description.-Fronds composed of short slender segments, $0.5-0.8 \mathrm{~mm}$ long and $0.17-0.29 \mathrm{~mm}$ wide with rather small nodes. Cells of medullary hypothallus $62 \mu-120 \mu$ long and $8 \mu-12 \mu$ wide. Marginal cells $20 \mu-39 \mu$ by $13 \mu-24 \mu$. Conceptacles unknown. Detailed dimensions (in microns) are given in the following table.

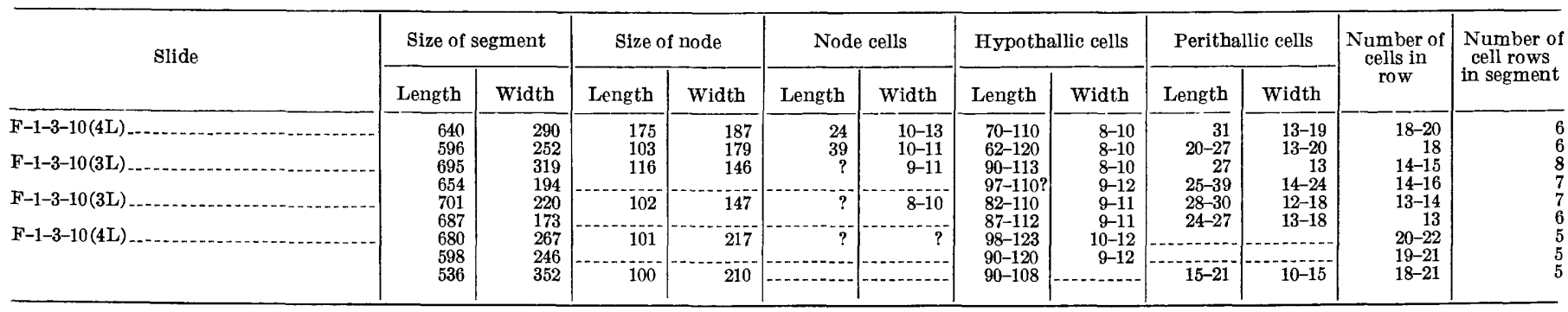


Remarks.-In general appearance this suggests Corallina neuschelorum Johnson but differs in having more slender fronds and larger cells.

Age: Miocene.

Locality: Eniwetok F-1, depth 1,230-1,248 ft (core).

Figured specimens: F-1-3-10(4) large, holotype, USNM 40828 ; F-1-3-10 (3) large, paratype, USNM 40827.

\section{Corallina neuschelorum Johnson}

Corallina neuschelorum Johnson, 1957, U.S. Geol. Survey Prof. Paper 280-E, p. 239, pl. 37, fig. 3, pl. 50, figs. 1-4.

Description.-Small delicate species; fronds formed of many short segments. Hypothallic cells $65 \mu-105 \mu$ long, $7 \mu-10 \mu$ wide. Marginal cells $10 \mu-15 \mu$ by $9 \mu-11 \mu$. Numerous measurements and illustrations given in original description.

Remarks.-Eniwetok specimens appear to be identical with species as described from the Miocene of Saipan. They occur abundantly in the F-1-5 core.

Age: Miocene.

Locality: Eniwetok F-1, depth 1,978-2,003 ft (core).

Corallina marshallensis Johnson, n. sp.

Plate 277, figures 2, 3

Description.-Segments $0.8-1.2 \mathrm{~mm}$ long and 0.259 $0.351 \mathrm{~mm}$ wide with 6 to 14 layers of cells. Top of layers flat or slightly depressed. Cells $99 \mu-140 \mu$ long and $9 \mu-12 \mu$ wide. Marginal cells $15 \mu-27 \mu$ wide and $9 \mu-13 \mu$ high. Node $200 \mu-250 \mu$ long. Conceptacles unknown.

Remarks.-This species has longer than average medullary cells and unusually wide marginal cells. Combination of cell dimensions differs considerably from that of any previously described Miocene species.

Age: Miocene.

Locality: Eniwetok F-1, depth 1,978-2,003 ft (core).

Figured specimens: F-1-5-33(2), holotype USNM 40829; USNM 40830.

\section{Corallina sp. A}

Plate 277, figure 5

Description.-Segments about $0.75 \mathrm{~mm}$ long and $0.25 \mathrm{~mm}$ wide. Nodes $0.08-0.09 \mathrm{~mm}$ long and $0.25 \mathrm{~mm}$ wide. Medullary hypothallic cells attain lengths of $115 \mu-126 \mu$ and widths of $9 \mu-14 \mu$. Marginal cells $20 \mu-$ $21 \mu$ by $13 \mu-16 \mu$. No conceptacles observed.

Remarks.-Represented by a number of worn pieces. Species is close to $C$. otsukiensis Ishijima in cell dimensions.

Age: Miocene.

Locality: Eniwetok F-1, depth 1,232-1,240 ft (core).

Figured specimen: F-1-3-3(2), USNM 40831.
Corallina sp. B

Plate 277, figure 1

Description.-Frond consists of number of segments containing 8 to 10 layers of cells. Segments $750 \mu-$ $1,000 \mu$ long; cells $42 \mu-64 \mu$ long, $8 \mu-11 \mu$ wide; nodes $110 \mu-140 \mu$ long. Conceptacles unknown.

Age: Miocene.

Locality: Eniwetok F-1, depth 1,718-1,740 ft (core).

Figured specimen: H-6, USNM 40832.

Corallina sp. C

Plate 277, figure 4

Description.-Segments cylindrical, $1.5-2.0 \mathrm{~mm}$ long and $0.3-0.4 \mathrm{~mm}$ in diameter with 16 to 18 gently arched layers of cells. Cells $63 \mu-81 \mu$ long, $11 \mu-13 \mu$ wide. Marginal cells $14 \mu-16 \mu$ long, $8 \mu-10 \mu$ wide. Nodes and conceptacles unknown.

Remarks.-In shape of segments and general appearance this species suggests Corallina elliptica Ishijima but has considerably shorter and wider cells. Represented by a number of fragments near base of F-1-5 core.

Age: Miocene.

Locality: Eniwetok F-1, depth 2,001-2,003 ft (core).

Figured specimen: F-1-5-40(5), USNM 40833.

\section{CHLOROPHYTA (green algae) \\ Family DASYCLADACEAE \\ Genus DACTYLOPORA Lamarck, 1816}

Dactylopora? sp.

Plate 278, figures 9-12; plate 279 , figures $3,4,5$

Description.-Horizontal segments $0.8-2.2 \mathrm{~mm}$ in diameter. Central stem $0.275-0.350 \mathrm{~mm}$ thick. Primary branches 26 to 28 in a whorl, with diameters of $40 \mu-$ $50 \mu$. No sporangia observed.

Remarks.-Represented by worn and poorly preserved horizontal segments that belong in or close to Dactylopora Lamarck.

Age: Late Eocene.

Locality: Eniwetok E-1, depth 2,802-2,808 ft (core).

Figured specimens: E-1-2-9 (2) large, USNM 40920; E-1-2-9

(3) large, USNM 40921; F-1, depth 2,805 ft, USNM 40942.

Genus ACICULARIA d'Archiac, 1943

Acicularia sp.

Plate 279, figures 6, 7

Numerous fragments of perforated calcareous plates appear to represent a member of this genus. They are too fragmentary to permit specific identification but are 
of interest as the first fossil representatives of this genus from the Pacific area.

Age: Late Eocene.

Locality: Eniwetok E-1, depth 2,802-2,808 ft (core).

Figured specimen: E-1-2-9, USNM 40944.

\section{Dasycladaceae occurrences in cuttings from E-1, Eniwetok}

Numerous specimens of Dasycladaceae were obtained from washed samples of well cuttings from Eniwetok hole E-1 in the interval between 2,780 and 3,100 feet. A superficial examination of the specimens yielded the following data:

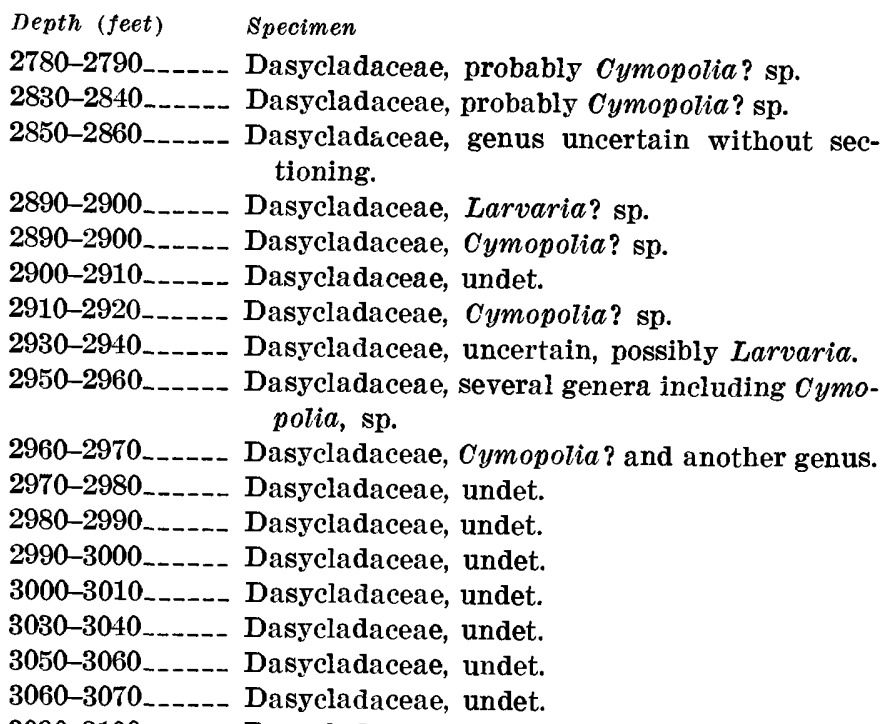
polia, sp.

2960-2970_._-_. Dasycladaceae, Cymopolia? and another genus. 2970-2980 _..... Dasycladaceae, undet.

2980-2990

2990-3000_....- Dasycladaceae, undet.

3000-3010_._._. Dasycladaceae, undet.

3030-3040 _._._- Dasycladaceae, undet.

3050-3060 ...... Dasycladaceae, undet.

3060-3070_-.-- Dasycladaceae, undet.

3090-3100_...... Dasycladaceae, undet.

\section{Family codiaceat}

\section{Genus HALIMEDA Lamouroux, 1812}

Plate 279, figures 1,2 ; plate 280 , figures $1-4$

These plants are bushy tufts of segmented branching stems or fronds. The segments may be subcylindrical, flattened, conical, or broad and leaflike. The young growing segments are bright green and uncalcified. Calcification occurs with age. It begins at the outer surface and is extended inward; the entire segment may eventually be calcified but commonly the process is incomplete.

Recent species of Halimeda are separated largely on the basis of the growth habit of the plant, structure of the nodes, and size and shape of the segments (Barton, 1901, p. 1-4). Because the fossils consist of loose segments it is seldom possible to assign them to species although the generic features are easily recognized.

Halimeda segments were numerous in all the Funafuti drill samples and were an important constituent in the lagoon drill holes (Halligan, 1904). A few were recognized in the Kita-Daito-Jima hole from sediments thought to be of Pleistocene age. In the Eniwetok drill holes, they were particularly abundant in the younger beds but segments were recovered from a core in hole $\mathbf{F}-1$ at a depth of 3,655-3,665 feet. Halimeda segments are so light and porous that they can travel almost indefinitely in heavy drilling mud. Some of the lowest occurrences from E-1 listed below may have been derived from younger horizons.

Figured specimens: From Eniwetok, USNM 40941 ; Kita Daitō Jima ; Funafuti core.

Occurrences of HALIMEDA in cuttings from E-1, Eniwetok

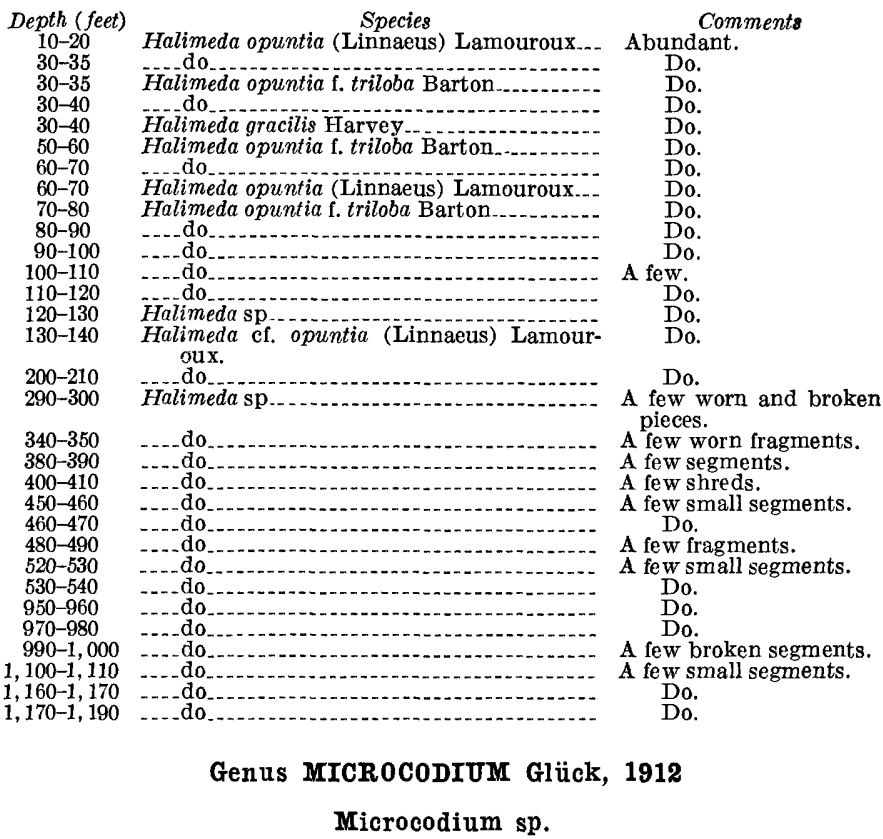

Description.-Thallus spherical, globular, or forming an irregular crust. In section usually elliptical, circular, or fan shaped. Consists of a circular or elongated central part or nucleus surrounded by large elongated petallike growths of "palisade cells." These fan out from the central portion of the circular or oval masses. The encrusting forms have a greatly elongated nucleus, from the sides of which the palisade cells grow out roughly parallel to one another.

The structure of the central part or nucleus is not preserved. The palisade cells appear as blades of clear or nearly clear crystalline calcite.

Some typical dimensions (in microns) are tabulated as follows.

\begin{tabular}{|c|c|c|c|c|c|c|c|}
\hline \multirow{2}{*}{ Slide } & \multicolumn{3}{|c|}{ Entire plant } & \multicolumn{2}{|c|}{ Nucleus } & \multicolumn{2}{|c|}{ Palisade cells } \\
\hline & Shape & Length & Width & Length & Width & Length & width \\
\hline 661 & $\begin{array}{l}\text { Rounded....... } \\
\text { Elongated }\end{array}$ & $\begin{array}{r}500 \\
485 \\
1160\end{array}$ & $\begin{array}{l}400 \\
410 \\
600\end{array}$ & $\begin{array}{l}142 \\
205 \\
330\end{array}$ & $\begin{array}{l}135 \\
112 \\
122\end{array}$ & $\begin{array}{r}110-180 \\
115-185 \\
98-182\end{array}$ & $\begin{array}{l}35-65 \\
48-60 \\
35-62\end{array}$ \\
\hline & & & & & & & \\
\hline
\end{tabular}

Remark's.-Kita-Daito-Jima material agrees with Glück's (1912) original description from Miocene of 
Germany. It is identical with specimens found in Miocene of Saipan. Similar material was also observed in upper Miocene of Eniwetok. A discussion of this problematical organism has been published by Johnson (1953, p. 84-86).

\section{Age: Miocene.}

Locality: Kita-Daitō-Jima cores, depth $380 \mathrm{ft}(115-118 \mathrm{~m})$ and $630 \mathrm{ft}(189 \mathrm{~m})$. Eniwetok F-1, depth 1,232-1,248 ft (core).

Specimens: Tōhoku University colln., slides 661 and 821 ; Eniwetok F-1-3-3 and F-1-3-4.

\section{GEOGRAPHIC DISTRIBUTION AND STRATIGRAPHIC OCCURRENCES OF ALGAE}

The known geographical distribution and stratigraphic occurrences of species of algae described in the present report is given in the following tables.

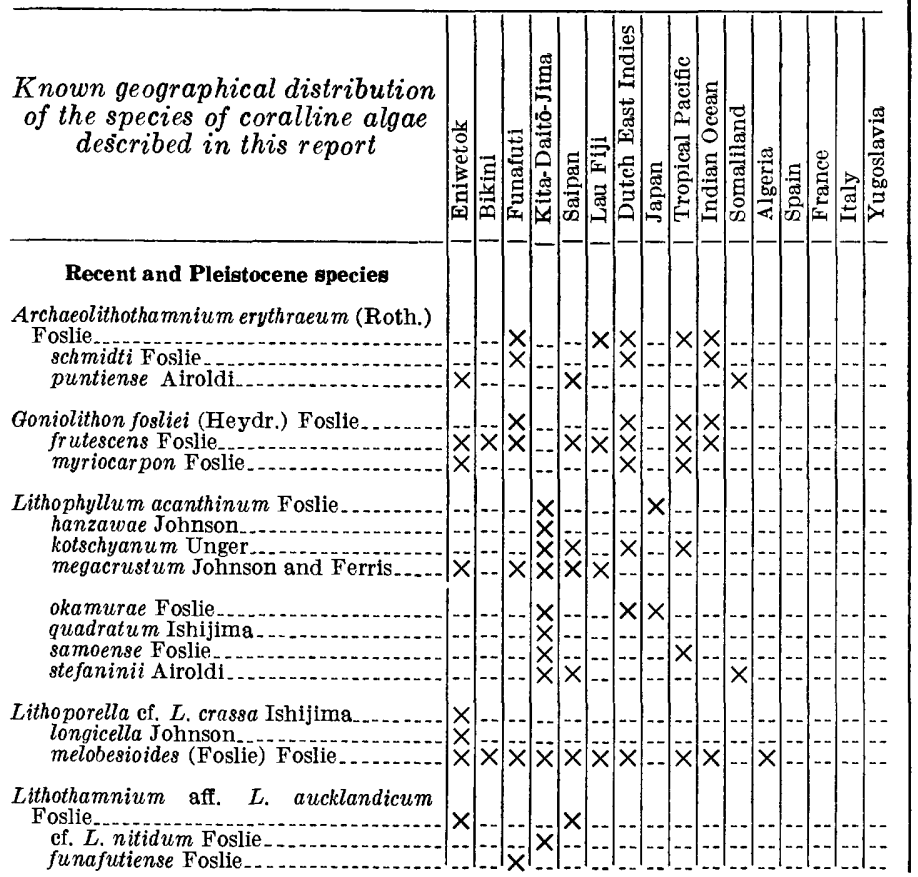

Occurrences of algae in drill holes F-1 and E-1

Depth (feet)

$0-45$
Drill hole $\mathrm{F}-\mathrm{I}$

Porolithon sp. and Halimeda opuntia (Linnaeus) Lamouroux.

45-110 Porolithon? sp., Halimeda? sp.

110-190 Halimeda? sp., Lithothamnium? sp

190-280 Halimeda $\mathrm{sp}$

280-330 No determinable algae..

330-625 Halimeda sp..... . . . . .

625-975 No algae recognized except fragments of Halimeda sp.

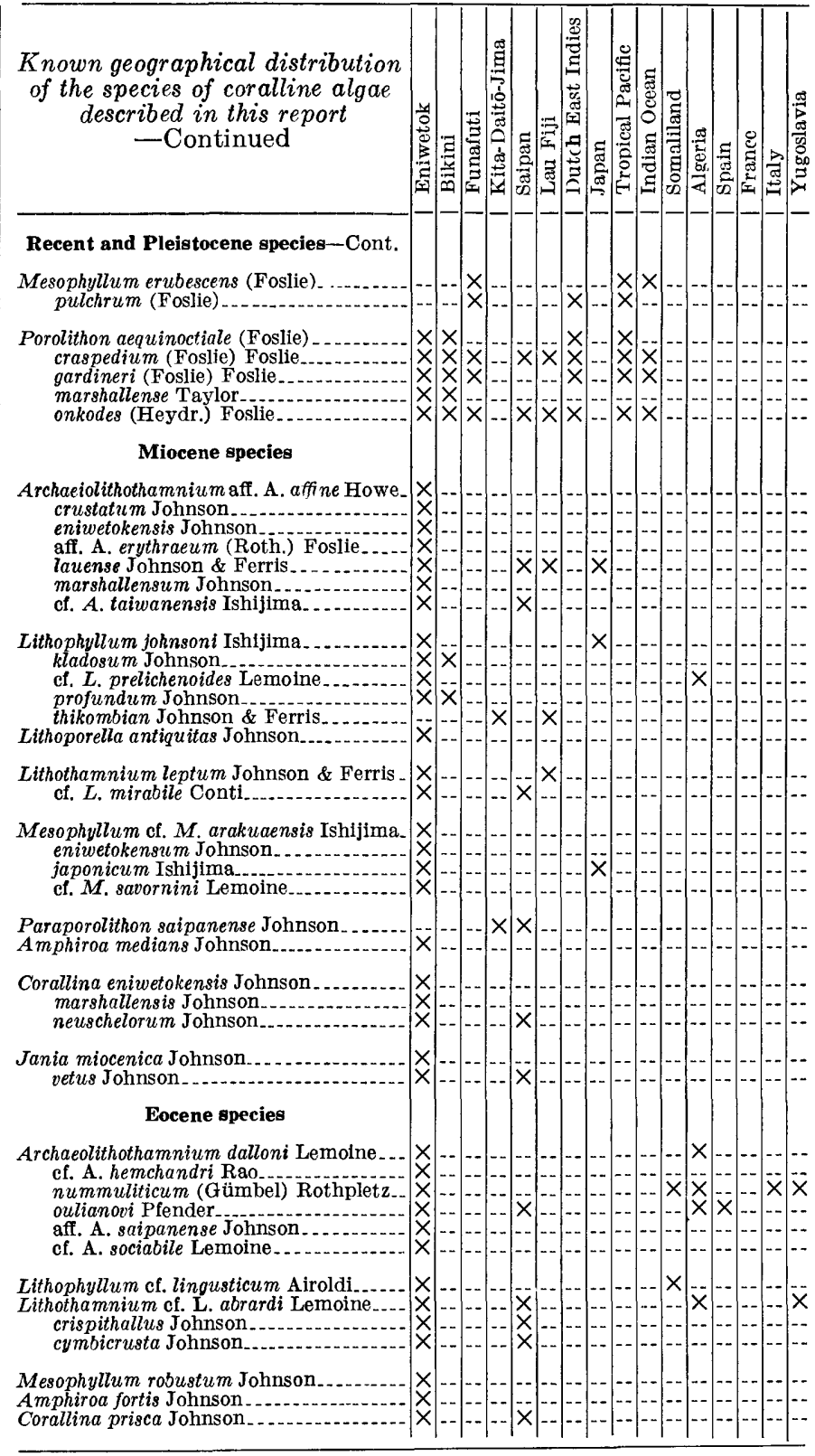

Depth (feet)

0-30 Porolithon onkodes (Heydrich) Foslie (10-30), Porolithon marshallensie Taylor (10), Halimeda opuntia (Linnaeus) Lamouroux.

30-90 Porolithon marshallense Taylor, Porolithon aequinoctiale (Foslie) Foslie (50-60), Halimeda opuntia (Linnaeus) Lamouroux, Halimeda gracilis Harvey.

90-145 Halimeda opuntia (Linnaeus) Lamouroux, Halimeda? sp.

145-300 Lithoporella longicella Johnson, n. sp. (260-270), Halimeda cf. H.opuntia (Linnaeus) Lamouroux.

300-530 Halimeda sp.

530-840 Halimeda sp.

840-1, 190 Occasional segments of Halimeda sp.

975-1, 045 No samples. 
Depth (feet)

$1,060-1,080$

$1,080-1,232$

$1,232-1,248$

$1,248-1,718$

$1,718-1,740$

$1,740-1,975$

$1,975-1,978$

$1,978-2,003$

$2,003-2,130$

$2,130-2,662$
$1,045-1,060$

No samples . . . .

Drill hole $F-1$

No algae recognized.

No samples.

No algae recognized.

Jania vetus Johnson, Corallina eniuetoken son, Corallina sp., A, Microcodium sp., Halimeda? sp.

No samples.

Archaeolithothamnium marshallensum Johnson, n. sp., Archaeolithothamnium of. A. taiwanensis Ishijima, Lithothamnium leptum Johnson and Ferris, Lithothamnium sp. C, Mesophyllum spp. A and B, Lithophyllum kladosum Johnson, Lithoporella sp. B, Jania miocenica Johnson, n. sp., Corallina sp. B.

No samples

Lithophyllum johnsoni Ishijima, Lithophyllum kladosum Johnson.

Archaeolithothamnium crustatum Johnson, n. sp., Archaeolithothamnium marshallensum Johnson, n. sp., Archaeolithothamnium eniwetokensis Johnson, n. sp., Lithothamnium cf. L. mirabile Conti, Lithothamnium sp. A, Mesophyllum ef. M. arakuraensis Ishijima, Mesophyllum eniwetokensum Johnson, n. sp., Mesophyllum japonicum Ishijima, Mesophyllum sp. A, Lithophyllum johnsoni Ishijima, Lithophyllum cf. L. prelichenoides Lemoine, Lithophyllum kladosum Johnson, Lithophyllum profundum Johnson, Lithoporella melobesioides (Foslie) Foslie, Jania mioceneium Johnson, n. sp., Amphiroa medians Johnson, n. sp., Amphiroa sp. C, Corallina neuschelorum Johnson, Corallina marshallensis Johnson, n. sp., Corallina sp. C.

No algae recognized.

(2.-.

2, 662-2,687 Archaeolithothamnium crustatum Johnson, n. sp., Archaeolithothamnium lauense Johnson and Ferris, Lithothamnium leptum Johnson and Ferris, Lithothamnium sp. B, Lithothamnium sp. C, Mesophyllum cf. M. arakuraenis Ishijima, Mesophyllum cf. M. savornini Lemoine. Lithoporella sp. A, Lithoporella melobesioides (Foslie) Foslie.

$2,687-3,052$ No samples

3, 052-3, 055 Mesophyllum robustum Johnson................

3, 055-3, 350 No samples . . . . . . . . . . . . . . . . . . . . . . . . .

$3,350-3,353 \quad$ Lithophyllum? sp.

$3,353-3,655$ No samples.

3, 655-3, 665 Archaeolithothamnium oulianovi Pfender, Archaeolithothamnium nummuliticum (Gümbel) Rothpletz, Archaeolithothamnium cf. A. hemchandri Rao, Lithophyllum cf. L. lingusticum Airoldi, Lithoporella melobesioides (Foslie) Foslie, Halimeda sp. (molds).
Depth (feet)

Drill hole $E-1$

1, 190-1, 230 No algae recognized.

1, 230-1, 715 No algae observed.

1, 715-1, 835 Archaeolithothamnium crustatum Johnson, n. sp. (1,718-1,740), Lithophyllum kladosum Johnson, Lithophyllum? sp., Lithoporella melobesioides (Foslie) Foslie.

1,835-1,993 Lithophyllum? sp., Lithoporella melobesioides (Foslie) Foslie.

1, 993-2, 003 Lithophyllum kladosum Johnson.

2, 003-2, 028 Lithopyhllum kladosum Johnson, Lithothamnium sp. D, Lithoporella antiquitas Johnson, n. sp.

2, 028-2, 349 No algae observed.

2, 350-2,355 Archaeolithothamnium aff. A. erythraeum (Rothpletz) Foslie, Archaeolithothamnium aff. $A$. affine Howe.

2, 355-2, 440 Lithophyllum kladosum Johnson, as rodlike branches.

2, 440-2, 600 Lithophyllum kladosum Johnson.

2,600-2, 802 Lithophy!lum sp. A (2,655), Lithophyllum kladosum Johnson $(2,680)$, Lithophyllum profundum Johnson (2,690-2,700), Archaeolithothamnium sp. B (2,730-2,740), Lithoporella melobesioides (Foslie) Foslie.

2, 802-2, 808 Archaeolithothamnium nummuliticum (Gümbel) Rothpletz, Archaeolithothamnium dallonii Lemoine, Lithoporella antiquitas Johnson, n. sp., Dactylopora? sp., Acicularia sp.

2, 808-3, 127 No algae observed.

$3,127-4,078$ No samples. 


\author{
Depth (feet) \\ 3, 665-3, 963 No samples. \\ 3, 963-3, 988 Lithophyllum? sp., Archaeolithothamnium eniwe- \\ tokensis Johnson, n. sp. \\ 3, 988-4, 197 No samples
}

4, 197-4, 222 Lithophyllum? sp., Archaeolithothamnium nummuliticum (Gümbel) Rothpletz, Amphiroa fortis Johnson, n. sp.

4, 222-4, 316 No samples.

4, 316-4,341 Lithophyllum? sp., Archaeolithothamnium? sp., Jania sp. A.

4, 341-4, 406 No samples.

4, 406-4, 431 Lithothamnium? sp., Lithophyllum sp.?

4, 431-4, 500 No samples.

4, 500-4, 525 Lithothamnium crispithallus Johnson, Amphiroa sp. B, Corallina prisca Johnson.

4, 525-4, 528 No samples.

4, 528-4, 553 Archaeolithothamnium cf. A. sociabile Lemoine, Archaeolithothamnium sp. A, Archaeolithothamnium aff. A. saipanense Johnson, Lithothamnium cf. $L$. abrardi Lemoine, Lithothamnium crispithallus Johnson, Lithothamnium cymbicrusta Johnson, Amphiroa sp. A, Corallina prisca Johnson.

4, 553-4, 610 No samples; probably limestone.

4, 610-4, 630 Probably basalt.

4, $630 \quad$ Total depth.

\section{DISTRIBUTION OF ALGAE IN BORING K-1, ENGEBI}

Halimeda segments were observed at intervals throughout K-1 (total depth $433 \mathrm{ft}, 6$ in). Remains of coralline algae were found at irregular intervals but were only abundant at two zones. The first, from the surface to a depth of 33 feet, contained much algal debris, mainly belonging to Porolithon onkodes (Heydrich) Foslie, Porolithon craspedium (Foslie) Foslie, Goniolithon frutescens Foslie, Goniolithon reinboldi Foslie, Goniolithon myriocarpon Foslie. The second zone, from 396-422 feet, contained an abundance of Lithoporella melobesioides (Foslie) Foslie, and a few pieces of Lithoporella crassa Ishijima, Lithophyllum megacrustum Johnson and Ferris, and Amphiroa? sp.

\section{DISTRIBUTION OF ALGAE IN FUNAFUTI BORING}

Algae were found throughout the length of the main boring on Funafuti, but their distribution was not uniform. The distribution of the forms that were identified in the present study is given on page 946 . Some zones were composed mostly of algae, but other zones contained only scattered fragments. At some levels the algae coated corals and other objects and appeared to be in position of growth. Elsewhere, they were represented by worn fragments which obviously had been transported some distance.

The abundance of algal remains in the Funafuti specimens seems to have been a surprise to those who
Depth (feet)

Drill hole $\mathrm{E}-1$

4, 078-4, 100 Algal debris, but too recrystallized to identify.

$4,100-4,170$ No samples.

4, 170-4, 190 Probably all basalt.

4, 190-4, 208 No samples.

4, 208-4, 222 Olivene basalt.

4, 222 Total depth. made the original study, and their comments on the subject have been quoted many times in later works.

The slides originally prepared for the Funafuti study are excellent for Foraminifera and most other organisms, but are too thick to permit accurate cell measurements of the contained algae; consequently, much of the algal material present cannot be specifically determined. Also recrystallization occurred and this becomes pronounced in specimens from lower levels. In most specimens the presence of algae can be recognized and in many cases the genus to which they belong can be surmised, but recrystallization has so disturbed and destroyed the cellular structure that it is impossible to make specific determinations.

Remains of Halimeda were found throughout the drill holes. They were surprisingly abundant in the upper parts and in lagoonal deposits. Finckh, in discussing the biology of the atoll, said of Halimeda:

This calcareous algae is abundant to an extraordinarily large extent in the lagoon and on the ocean slopes. In order to determine its bathymetrical distribution, systematic dredgings were carried on off the islets of Funamanu and Falefatu, with the result that it was invariably found to be present alive down to the 45-fathom limit. Beyond that depth it was never met with alive, except in the case of a specimen brought up in the tangles on one occasion off Tutanga islet from 80 fathoms. (Finckh, 1904, p. 135)

J. W. Judd, in discussing the materials from the lagoon of Funafuti, stated: 
The dredgings in the lagoon showed that except where bosses of coral rock rise and form shoals, often with only a few feet of water upon them at high tide, the whole of the bottom of of the Funafuti lagoon is covered with a dense growth of the green calcareous algae Halimeda opuntia Lam., a well-known member of the order Siphoneae, group Chlorophyceae. This growth of Halimeda appears to be most vigorous in the shallower parts of the lagoon, but everywhere it forms a green living carpet down to depths of 120 feet, and is occasionally found alive at greater depths. The Halimeda fronds are often more or less covered with attached organisms, such as the Foraminifera Sagenina, Polytrema, etc., with Spirorbis, Serpulae, Polyzoa, etc., and other organisms. Intermingled with the living Halimeda and its broken tunicate spicules, as well as remains of Pteropoda, Gastropoda, Pelecypoda, Crustaceae and other forms of animal life, were several forms of Lithothamnium. In the central and deeper parts the number of Foraminifera is comparatively small, seldom exceeding 10 percent of the whole mass, and consisting only of species adherent to the fronds of Halimeda, with the free forms Amphistegina and Heterostegina. (Judd, 1904, p. 176-177)

Professor Hinde, reporting on the material from the borings, stated regarding the genus Halimeda:

Detached joints of this genus are present in all the borings; in some portions, as for example in the Lagoon Boring, for 60 feet below the lagoon floor, they form the greater part of the rock, and between 652-660 feet in the Main Boring they are the main constituents of the cores. As a rule their structure is well-preserved, so that they are readily recognized in microscopic sections. (Hinde, 1904, p. 331-332)

\section{OCCURRENCES OF ALGAE IN FUNAFUTI BORING}

Recent Porolithon onkodes (Heydrich) Foslie, Porolithon Reef craspedium Foslie, Porolithon gardineri Foslie, and Goniolithon frutescens Foslie, Lithothamnium Lagoon philippii Foslie, Lithophyllum subtilis Foslie, Halimeda opuntia Lamarck, Halimeda cunesta Kutzling, Halimeda tuna Lamarck, Halimeda gracilis Harvey.

$\begin{gathered}\text { Depth } \\ \text { (feet) }\end{gathered}$
$0-10$
$10-20$

Halimeda? sp.

Porolithon gardineri Foslie, Porolithon onkodes (Heydrich) Foslie, Lithoporella melobesioides (Foslie) Foslie, Halimeda? sp.

20-30 Mesophyllum erubescens (Foslie), Porolithon gardineri Foslie, Mesophyllum (Lithophyllum) australe Foslie, Halimeda sp.

60-70 Lithoporella melobesioides (Foslie) Foslie, Corallina sp., Halimeda sp.

80-90 Halimeda? sp.

110-120 Lithothamnium? sp., Lithophyllum? sp., Halimeda? sp.

210-220 Lithophyllum sp., Lithoporella melobesioides (Foslie) Foslie.

420-433 Lithophyllum sp?, Halimeda? sp.

452 Lithothamnium funafutiense Foslie, Lithoporella melobesioides (Foslie) Foslie.

$500 \quad$ Goniolithon frutescens Foslie.

526 Goniolithon fosliei (Heydrich) Foslie, Goniolithon frutescens Foslie, Lithoporella melobesioides (Foslie) Foslie, Lithophyllum sp., Halimeda sp.

547-555 Porolithon gardineri Foslie, Lithophyllum sp.
Depth
(feet)

$643-652$

$691-698$

$736-748$

764

$791-798$

$867-874$

880

$891-899$

$950-957$

973

$1,006-1,015$

$1,087-1,100$

1,100-1,114 Lithophyllum sp., Lithothamnium sp.

\section{OCCURRENCES OF ALGAE IN KITA-DATTŌ-JIMA BORING}

Surface

17

23

25

29-30

37

51

$60-78$

87

115

130-135

160-165

173

200

227-230

243

273

283

333

350

367

380

Lithophyllum? sp., Lithoporella? sp., Halimeda sp. Archaeolithothamnium schmidti, Foslie, Lithophyllum sp., Halimeda sp.

Archaeolithothamnium erythraeum (Rothpletz), Mesophyllum pulchrum (Foslie), Goniolithon frutescens Foslie, Halimeda sp.

Archaeolithothamnium erythraeum (Rothpletz) Foslie, Lithothamnium sp., Halimeda sp.

Porolithon cf. P. onkodes (Heydrich) Foslie, Lithothamnium funafutiense Foslie.

Archaeolithothamnium erythraeum (Rothpletz) Foslie, Lithophyllum sp., Halimeda sp.

Lithothamnium funafutiense? Foslie.

Archaeolithothamnium erythraeum (Rothpletz) Foslie, Lithophyllum megacrustum Johnson and Ferris, Lithoporella melobesioides (Foslie) Foslie.

Goniolithon frutescens Foslie, Mesophyllum cf. $M$. australe Foslie.

Lithoporella melobesioides (Foslie) Foslie.

Lithothamnium sp., Lithophyllum sp., Halimeda sp.

Lithophyllum sp., Lithothamnium sp., Halimeda? s.

Jania sp., Corallina sp., Lithoporella melobesioides (Foslie) Foslie, Lithophyllum megacrustum Johnson and Ferris, Lithophyllum okamurae Foslie.

Archaeolithothamnium puntiense Airoldi, Lithothamnium cf. L. nitidum Foslie.

Lithophyllum cf. L. stefaninii Airoldi, Lithophyllum acanthinum Foslie.

Lithophyllum acanthinum Foslie.

Lithophyllum quadratum Ishijima, Lithophyllum samoense Foslie, Lithophyllum yessoense Foslie.

Lithophyllum ef. L. kotschyanum Unger, Lithoporella melobesioides (Foslie) Foslie.

Archaeolithothamnium puntiense Airoldi, Lithothamnium aff. L. aucklandicum Foslie, Lithophyllum hanzawae Johnson $\mathrm{n}$. sp.

Lithophyllum megacrustum Johnson and Ferris, Lithophyllum okamurae Foslie, Halimeda sp.

Halimeda sp.

Lithoporella?, sp. Halimeda sp.

Halimeda? sp.

Lithophyllum megacrustum Johnson and Ferris, Halimeda sp., Archaeolithothamnium puntiense Airoldi.

Lithothamnium aff. L. aucklandicum Foslie, Halimeda sp.

Lithophyllum megacrustum Johnson and Ferris, Halimeda? sp.

Halimeda? sp.

Halimeda? sp.

Halimeda sp.

Halimeda? sp.

Lithoporella melobesioides (Foslie) Foslie.

Lithophyllum cf. L. kotschyanum Unger.

Lithoporella sp. C, Lithophyllum acanthinum Foslie, Lithophyllum stefaninii Airoldi, Lithophyllum thikombian Johnson and Ferris.

Lithophyllum acanthinum Foslie, Microcodium sp. 


\author{
Lithophyllum thikombian Johnson and Ferris, \\ Lithoporella melobesioides (Foslie) Foslie, Micro- \\ codium sp. \\ Lithophyllum sp. B. \\ Archaeolithothamnium puntiense Airoldi, Litho- \\ porella melobesioides (Foslie) Foslie. \\ Dermatolithon? sp. \\ Microcodium sp. \\ Dermatolithon? sp., Jania? sp., Paraporolithon \\ saipanense Johnson.
}

\section{SELECTED BIBLIOGRAPHY}

Airoldi, Marco, 1933, Le Corallinacee del Pleistocene della Somalia Italiana. VI-Fossili del Pliocene e del Pleistocene: Palaeontographica Italia, Mem. Palaeont., v. 32, supp. 1, p. 79-96, pls. 6-7, figs. 9-11.

Barton, E. S. [Mrs. Gepp], 1901, The Genus Halimeda: SibogaExpeditie Mon. 60, p. 1-32, pls. 1-4.

Chapman, Frederick, 1901, Foraminifera from the lagoon at Funafuti : Linnean Soc. London Jour. Botany, v. 28, no. 181, p. 161-201.

Chapman, V. J., 1955, Algal collections from Funafuti Atoll: Pacific Science, v. 9, p. 354-356.

Dawson, E. Y., 1944, Marine algae of the Gulf of California: Allan Hancock Pacific Expeditions v. 3, no. 10, 452 p., 7i pls., Univ. Southern California Press.

1952, Marine red algae of Pacific Mexico: Part 1. Allan Hancock Pacific Expeditions v. 17, no. 1, 238 p., 33 pls. 1954, Marine plants in the vicinity of Nha Trang, Viet Nam: Pacific Science v. 8, no. 4, p. 373-469, 63 figs. 1957, Annotated list of marine algae from Eniwetok, Marshall Islands: Pacific Science, v. 11, no. 1, p. 92-132.

Doty, M. S., 1957, Rocky intertidal surfaces, in Treatise on marine ecology and paleoecology : Geol. Soc. America Mem. 67 , v. 1 , p. 535-585.

Emery, K. O., Tracey, J. I., Jr., and Ladd, H. S., 1954, Geology of Bikini and nearby atolls: U.S. Geol. Survey Prof. Paper $260-\mathrm{A}, 265$, pp., 64 pls.

Finckh, A. E., 1904, Biology of the reef-forming organisms at Funafuti Atoll : Royal Soc. Report, Atoll of Funafuti, sec. 6, p. $125-150$.

Foslie, M. H., 1909, Algologiske Notiser VI: K. norske vidensk. selsk. Skr., no. 2, p. 1-63.

Foslie, M. H., and Printz, Henrik, 1929, Contributions to a monograph of the Lithothamnia: K. norske vidensk. selsk. museet. Mon., 60 p., 75 pls.

Glïck, Henrich, 1912, Eine neue gesteinsbildende Siphonee (Codiacee) aus dem Marinen Tertiär von Siiddeutschland : Mitt. der gross Badischen geol. Landesanstalt, v. 7, no. 1, p. 1-24, pls. 1-4.

Halligan, G. H., 1904, Report of lagoon borings, in Atoll of Funafuti: Royal Soc. London Philos. Trans., p. 160-164.

Hanzawa, Shoshiro, 1940-41, Micropaleontological studies of drill cores from a deep well in Kita-Daitō-Jima (North Borodino Island) : Jubilee Publication in Commemoration of Professor H. Yabe's Sixtieth Birthday, Geological and Paleontological Institute, Tōhoku Imp. Univ. Sci. Repts., v. 2 , p. $755-802$, pls. $39-42$, Sendai, Japan.

Hinde, G. J., 1904, Report on the materials from the borings at the Funafuti Atoll: Section 11, Report Royal Soc., Atoll of Funafuti, p. 186-361.

Howe, M. A., 1919, Tertiary calcareous algae from the islands of St. Bartholomew, Antigua, and Anguilla : Carnegie Inst. Washington Pub. 291, p. 9-20, pls. 1-6.
Ishijima, Wataru, 1933, on three species of Corallinaceae lately obtained from the Megamiyama limestone, Sagara District, Province of Totomi, Japan: Japanese Jour. Geology and Geography, v. 11, nos. 1-2, p. 27-30, pls. 5.

1954, Cenozoic coralline algae from the western pacific [Private publication]: $87 \mathrm{p} ., 49 \mathrm{pls}$, Tokyo, Japan.

Johnson, J. H., 1953, "MIicrocodium" Glück, est-il un organisme fossile?: Acad. sci. Paris Comptes rendus, v. 237, p. 84-86. 1954a, An introduction to the study of rock building algae and algal limestones: Colorado School of Mines Quart. v. 49, no. 2, p. 117, pl. 62.

1954b, Fossil calcareous algae from Bikini Atoll: U.S. Geol. Survey Prof. Paper 260-M, p. 537-545, pls. 188-197. 1957, Geology of Saipan, Mariana Islands; calcareous algae : U.S. Geol. Survey Prof. Paper 280-E, p. 209-243, pl. $37-60$.

Johnson, J. H., and Ferris, B. J., 1950, Tertiary and Pleistocene coralline algae from Lau, Fiji: B. P. Bishop Mus. Bull. 201, p. 1-27, pls. 1-9.

Judd, C. B., 1904, General report on the materials sent from Funafuti: Report Royal Soc., Atoll of Funafuti, section 10 , p. 167-185.

Ladd, H. S., Ingerson, Earl, Townsend, R. C., Russell, Martin, and Stephenson, H. K., 1953, Drilling at Eniwetok Atoll, Marshall Islands: Am. Assoc. Petroleum Geologists Bull.. v. 37, no. 10 p. $2257-2280$.

Ladd, H. S. and Schlanger, S. O., 1960, Drilling operations on Eniwetok Atoll: U.S. Geol. Survey Prof. Paper 260-Y, p. 863-903, pls. 265-266.

Lemoine, Mme. Paul, 1911, Structure anatomique des Mélobésiées : Inst. Oceanographique, Ann., v. 2, pt. 2.

1928, Un nouveau genre de Mélobésiées, Mesophyllum: Soc. bot. France Bull., 5th ser., v. 75, p. 251-254.

__ 1939, Les algues calcaires fossiles de l'Algerie: Mat. Carte géol. de l'Algerie, ser. 1, Paleont. no. 9, 128 p., 3 pls., 80 figs.

Lemoine, J. V., 1940, Les algues calcaires de la zone néritique, from Contribution a l'étude de la repartition actuelle et passée des organisms dans la zone néritique: Soc. Biogéographie, Paul Lechevalier, Paris, v. 7, p. 75-128.

Lignac-Grutterink, L. H., 1943, Some Tertiary Corallinaceae of the Malaysian Archipelago: Geol.-mijnb. genootsch. Nederland en Kolonien Verh., Geol. ser., v. 113, p. 283-297, 2 pls.

Ota, Yasuski, 1938, Cores from the test drilling on Kita-DaitoJima. Examination, chemical analyses, and microscopic study of the Daito limestone: Institute Geol. and Paleontology, Töhoku Imp. Univ. Contr. no. 30, 25 p., 19 figs. [In Japanese.]

Pia, Julius, 1926, Pflanzen als Gesteinsbildner: Berlin, $355 \mathrm{p}$. 1927, Die Ehrhaltung der fossilen Pflanzen, Part 1, Thallophyta, in Hirmer, Max, Handbuck der Paläobotanik : Berlin and München, p. 31-113.

Royal Society of London, 1904, The Atoll of Funafuti : Borings into a coral reef and the results: Being the report of the Coral Reef Committee of the Royal Society, 428 p., 6 pl., 68 figs., maps.

Taylor, Wm. R., 1950, Plants of Bikini and other northern Marshall Islands : Mich. Univ. Studies, Sci. Ser., v. 18, 227 p., 79 pls.

Weber van Bosse, Anna, and Foslie, M. H., 1904, The Corallinaceae of the Siboga Expedition; Siboga-Expeditie Mon. 61, 110 p., 16 pls., 34 figs.

Yamada, Y., 1934, The marine Chlorophyceae from Ryukyu, especially from the vicinity of Nawa : Hokkaido Imp. Univ. Fac. Sci. Jour. S. 5, v. 3, no. 2, p. 33-88, 55 figs. 


\section{INDEX}

[Italic numbers indicate description]

abrardi, Lithothamnium................ 922,943,945 Abstract acanthinum, Lithophyllum.......... 928,943,946, pl. 273 Acetabularia ...................................... 913 Acicularia ............................... 910,941-942

sp _............................ 941,944, pl. 279

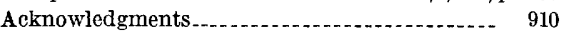
aequinoctiale, Lithophyllum .................. 934

Porolithon 933,934, pl. 275 affine, Archaeolithothamnium _.. 917, 921,943, 944, pl. 269 Age, algae as indicators of . . . . . . Algal ridge . . . A mphiroa . . . ............ 910,912,913,938, 939-940 fortis................ 939, 943, 945, pl. 277 medians . . . . . . . . ............... 939,943, 944, pl. 278 sp sp. A _. . . . sp. B $\mathrm{B}$ sp. C . . . . . . . . . . . . . . . . . 940,944, pl. 278 Amphistegina.... 946 antiquitas, Lithoporella........ 936, 937,943,944, pl. 276 araii, Lithotha mnium ........................... 923 arakuraensis, Mesophyllum _... 925,943, 944, pls. 270, 271 Archaeolithothamnion. (See Archaeolithothamnium.)

Archaeolithothamnium ............ 910,911, 912,916-921 affine ..................... 917,921,943, 944, pl. 269 chamorrosum 918 crustatum dallonii .................... 917, 921, 943,944, pl. 268 eniwetokensis _...... 917,918,943, 944,945, pls. 267,268 erythraeum ........ 917,919, 920,943,914,946, pl. 268 hemchandri . . . . . . . . intermedium ............................. 917 kuboiensis lauense ......................... 917, 943,944, pl. 267 marshallensum............. 917, 943,944, pls. 267, 269 megamiensis........................ 918, 920 nummuliticum ............................ 917 $920,921,943,944,945$, pls. 268,26 oulianovi_....................... 917,918,919,943,944 puntiense _......... 917,918, 943, 946,947 saipanense $\ldots . . . . . . . . . . . . . . . . . . ~ 917,920,921,943,945$ schmidti ....................... 917, 918, 919,943,946 sibogae .................................... 918 sociabile . . ................ 917,919,943,945, pl. 267 taiwanensis........... 917, 919,920,943, 944, pl. 267 timorense............................... 921 sp sp. A _... sp. B............................... 917, 921,944 Arthrocardia ................................ 910, 912 Articulate coralline algae. (See Corallinoideae.) aucklandicum, Lithothamnium ................ 922, 928, 924, 943, 946, pl. 270

australe, Lithothamnium Mesophyllum......................... 925, 927, 946 Mesophyllum (Lithophyllum) _.............. 946 australis, Lithoporella

Lithothamnium coralloides..................... 927

\section{B}

Bibliography, selected......................... 947 Bikini A toll........................ 907, 914, 943, fig. 288 bikiniensum, Lithothamnium.................... 923 Bossea

Calliarthron 912

camarasae, Lithothamnium ........... 927 chamorrosum, Archaeolithothamnium ............ 918 Charophyta.................................. 910 Cheilosporum ................................ 912

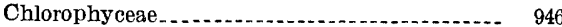
Chlorophy ta (green algae) ......... 910, 913, 914, 941-943 (Cladolithon) frutescens, Goniolithon............

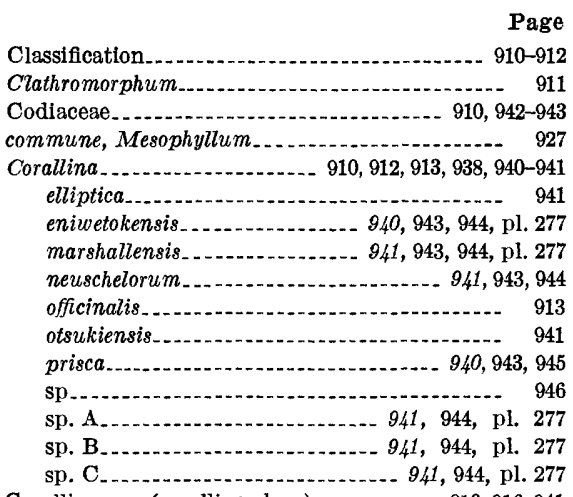

Corallinaceae (coralline algae) .........-910, 916-941 Corallinoideae (articulate coralline algae) ....... 910 ,

Coralline algae. (See Corallinaceae.) $912,913,938-941$ coralloides australis, Lithothamnium Corals.-.-...- 907 craspedium, Lithophyllum Porolithon crassa, Lithoporella $\ldots . . . . . . . . . . . ~ 986,937,943,945$, p1. 276 crispithallus, Lithothamnium............. 922, 943, 945

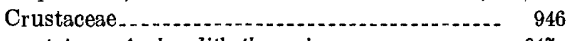
crustatum, Archaeolithothamnium.............. 917, 943, 944, pl. 267 Crustose coralline algae. (See Melobesioideae.) Cryptonemiales................................ 916 cunesta, Halimeda............................. 946 Cyanophyta (blue-green algae) . . cymbicrusta, Lithothamnium ............ . 922, 923, 943, 945 Cymopolia sp

\section{D}

Dactylopora -.. 910,941

sp _... . . . . 941,944 , pls. 278, 279 dallonii, Archaeolithothamnium. 917,921,943, 944, pl. 268 Dasycladaceae.... ......... 910, 913, 914, 915, 916, 941-942 Dermatolithon .......................... 910,912, 937-938 marshallensum . . . . . . . 938, pl. 277 papillosum saipanensum

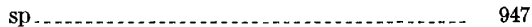

Distribution ...................... 912-915, 943-946 Boring K-1, Engebi Island............. 945 Funafuti boring . . . . .

Ecological indicators, algae as................. 916 elliptica, Corallina. ......................... 941 Elugelab _.......... Engebi_................. _. Eniwetok Atoll, Marshall Islands . . ........ 907 , $908,915,943$, figs. 288,289 eniwetokensis, Archaeolithothamnium .......... 917, $918,943,944,945$, pls. 267, 268 Corallina__..._..... 940,943,944, pl. 277 eniwetokensum, Mesophyllum _ 925,926,943,944, pl. 272 erubescens, Lithothamnium.................... 922 Mesophyllum erythraeum, Archaeolithothamnium ........... 917, $919,920,943,944,946$, pl. 268

Lithothamnium F

Fiji, Lau_..._.

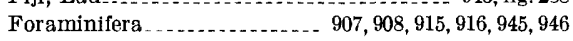
fortis, Amphiroa . . . _........... 939, 943, 945, pl. 277 fosliei, Goniolithon ..........932, 933, 943, 946, pl. 275 Lithophyllum $m_{\ldots}$ Lithothamnium......................... 932
Page

Fosliella.... 911 frutescens, Goniolithon Goniolithon (Cladolithon) Funafuti Atoll, Ellice Islands.................... 907, $908,915,943,945,946$, fig. 288

funafutiense, Lithothamnitm ... 922, 924, 943, 946, pl. 270 G

gardineri, Lithophyllum Lithophyllum (Porolithon) Porolithon . .............. 914, 933, 934, 935, 943, 946 Gastropoda Geographic distribution and stratigraphic occurrences of algae............... 943-947 Goniolithon _.............. 910,911, 912, 913, 932-933, 935 (Cladolithon) frutescens...................... 932 fostiei frutescens......................... 932, 943, 945,946 myriocarpon _ . ................ 932,943, 945, pl. 275

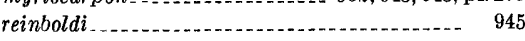
gracilis, Halimeda....................... 942, 943, 946 Green algae. (See Chlorophyta.)

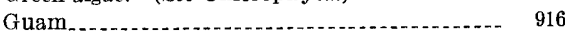

H

Halimeda............. 910, 913, 914,915, 916, 942, 945, 946 cunesta................... $910,913,914,915,916,942,945,946$

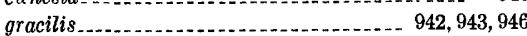
opuntia.................................... 942, 943, 946 triloba tuna sp . hanzawae, Lithophyllum .......... 928, 943, 946, pl. 272 hemchandri, Archaeolithothamnium _...... 917, $921,943,944$, pl. 268

heteroclitum, Mesophyllum Heteroderma . . .

Heterostegina. . . . Hydrolithon .......... 911

\section{I, J}

intermedium, Archaeolithothamnium............ 917 Introduction.................................. 907 irregularis, Lithophyllum .................... 931 Jania miocenica................. 938, 943, 944, pl. 278 vetus_................................. 939, 943, 944 sp $\ldots$

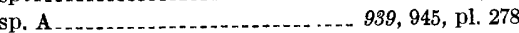
japonicum, Mesophyllum_.... 925, 926, 943, 944, pl. 271 Joculator . . . johnsoni, Lithophyllum $\ldots . . . . . . . . . . .928,929,943,944$ $\mathbf{K}$

Keys to the genera of the articuiate coralline

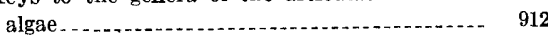
Keys to the tribes and genera of the crustose coralline algae. ............................... 911-192 Kita-Daitō-Jima, Philippine Sea.... $908,915,943,946$, fig. 288 kladosum, Lithophyllum. 928, 931, 943, 944, pls. 272, 274 koritzae, Mesophyllum kotschyanum, Lithophyllum... 928, 931, 943, 946, pl. 274 kuboiensis, Archaeolithothamnium.

$\mathbf{L}$

Laminariales.

Larvaria sp. .................................... 942 lauense, Archaeolithothamnium _... 917, 943, 944, pl. 267 Lithothamnium. . leptum, Lithothamnium ...... 922, 923, 943, 944, pl. 270 Limestone builders, algae as .................. 915 lingusticum, Lithophyllum.... 928, 929, 943, 944, pl. 272 Lithophylleae 


\section{PLATES 267-280}




\section{PLATE 267}

Figures 1-2. Archaeolithothamnium crustatum Johnson, n. sp. (p. 917).

1. A perpendicular section through the crust, $\times 95$. Shows a narrow irregular hypothallus, a well-developed perithallus, and a number of sporangia. Miocene. Eniwetok. Holotype USNM 51424.

2. Specimen showing the irregular hypothallus at the base and a crust made of several superimposed thalli, $\times 48$. Miocene. Eniwetok. USNM 51425.

3, 4. Archaeolithothamnium cf. A. sociabile Lemoine (p. 919).

3. A fragment showing part of the perithallus with numerous sporangia, $\times 48$. Late Eocene. Eniwetok. USNM 51431.

4. Specimen giving details of the tissue and sporangia, $\times 48$. Late Eocene. Eniwetok. USNM 51432.

5. Archaeolithothamnium marshallensum Johnson, n. sp. (p. 917).

A section of a crust showing a slightly developed hypothallus, and the perithallic tissue with a cluster of sporangia, $\times 48$. Miocene. Eniwetok. Holotype. USNM 51427.

6. Archaeolithothamnium eniwetokensis Johnson, n. sp. (p. 918).

Section of crust, with a hypothallus consisting of a few curved rows of cells; fairly regular perithallic tissue and a row of sporangia, $X 48$. Miocene. Eniwetok. Holotype USNM 51429.

7. Archaeolithothamnium ef. A. taiwanensis Ishijima (p. 919).

Oblique section through a small fragment, $\times 95$. Miocene. Eniwetok. USNM 51433.

8. Archaeolithothamnium lauense Johnson and Ferris (p. 917).

Section showing the relatively thick basal hypothallus, the regular well-developed perithallus, and two rows of sporangia, $\times 48$. Miocene. Eniwetok. USNM 51426 .

9. Archaeolithothamnium sp. A. (p. 919).

Oblique section of a thin slightly recrystallized crust with sporangia. Part of alga is growing around an encrusting foraminifer, $\times 48$. Late Eocene. Eniwetok. USNM 51434. 
GEOLOGICAL SURVEY

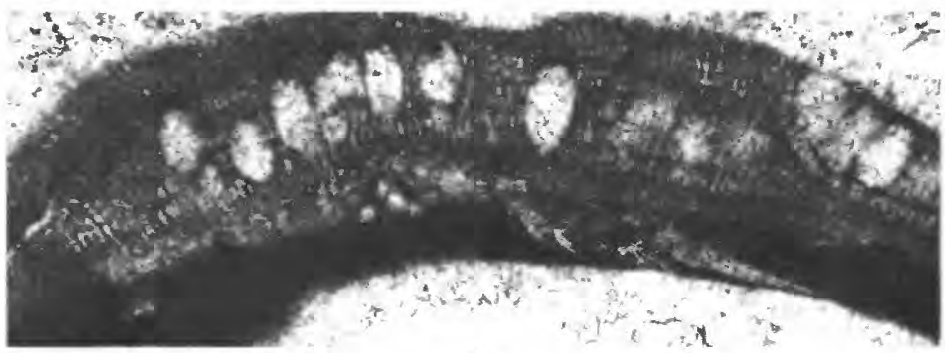

1
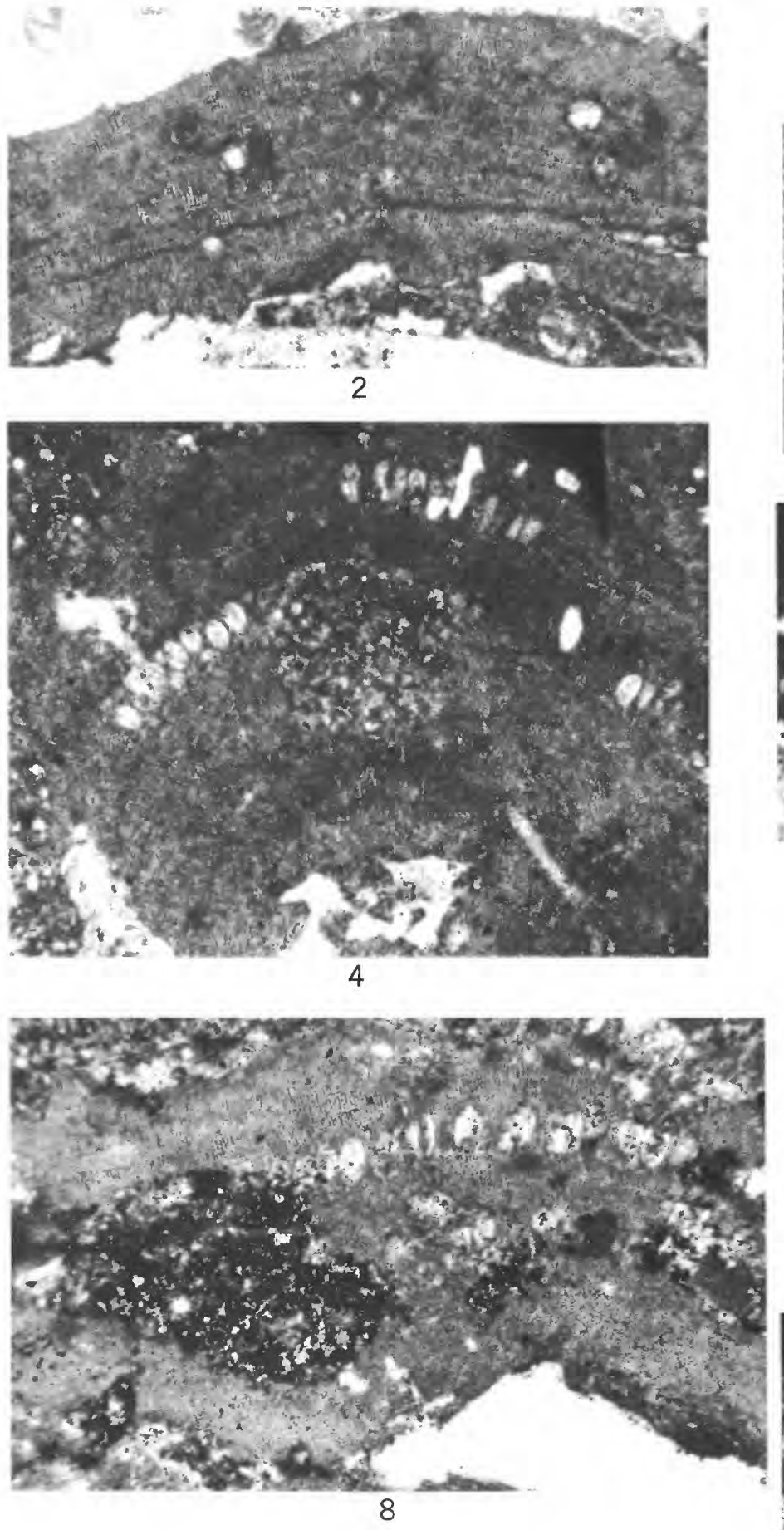

PROFESSIONAL PAPER 260 PLATE 267

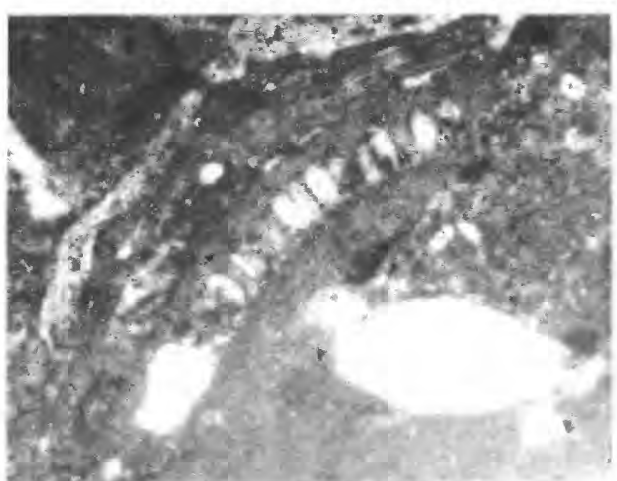

3

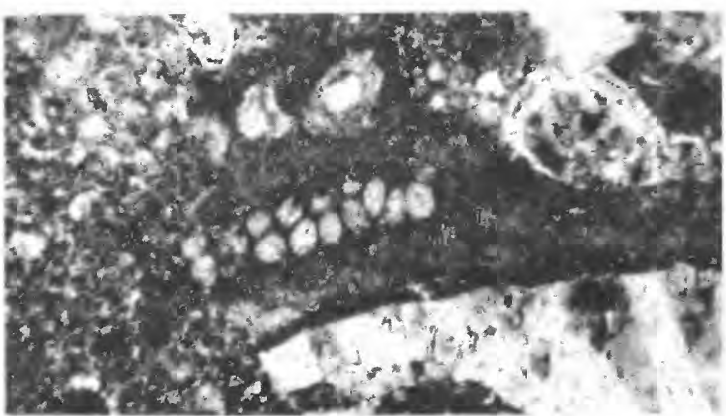

5

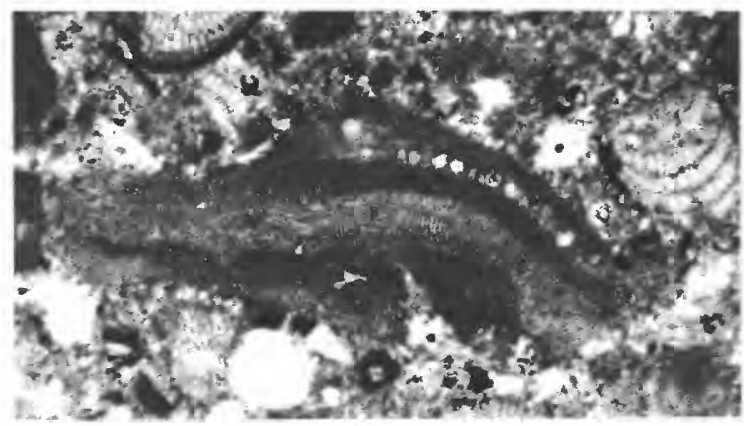
6
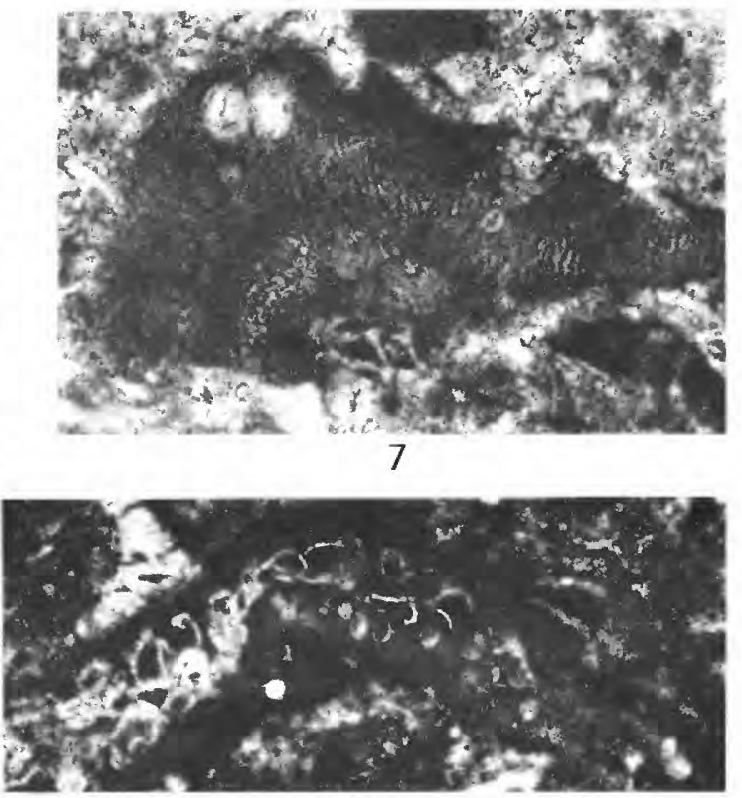


\section{PLATE 268}

FugURE 1. Archaeolithothamnium eniwetokensis Johnson, n. sp. (p. 918).

Detail of hypothallus and perithallus, $\times 95$. Miocene. Eniwetok. USNM 51430.

2, 3. Archaeolithothamnium erythraeum (Rothpletz) Foslie (p. 919).

2. Section of a considerably recrystallized specimen giving a general idea of the thallus and the sporangia, $\times 38$. Pleistocene or Recent. Funafuti. British Museum slide 773.

3. Recrystallized specimen showing thin crust with numerous sporangia $\times 38$. Pleistocene or Recent. Funafuti. British Museum slide 773 .

4. Archaeolithothamnium aff. A. erythraeum (Rothpletz) Foslie (p. 920).

Detail of perithallic tissue and sporangial cavities, $\times 95$. Miocene. Eniwetok. USNM 51435.

5. Archaeolithothamnium dallonii Lemoine (p. 921).

Slightly oblique longitudinal section of a branch showing the tissue and scattered sporangia, $\times 48$. Late Eocene. Eniwetok. USNM 51439.

6. Archaeolithothamnium nummuliticum (Gümbel) Rothpletz (p. 920).

Section through a knobby crust, at the base is a fairly well developed hypothallus with curved cell rows, another patch of hypothallic tissue near the center probably represents scar tissue; a well-developed perithallus with sporangia is at the top, $\times 48$. Late Eocene. Eniwetok. USNM 40813.

7. Archaeolithothamnium cf. A. hemchandri Rao (p. 921).

A vertical section of a fragment consisting of perithallic tissue containimg some sporangia, $\times 95$. Late Eocene. Eniwetok. USNM 51437. 
GEOLOGICAL SURVEY
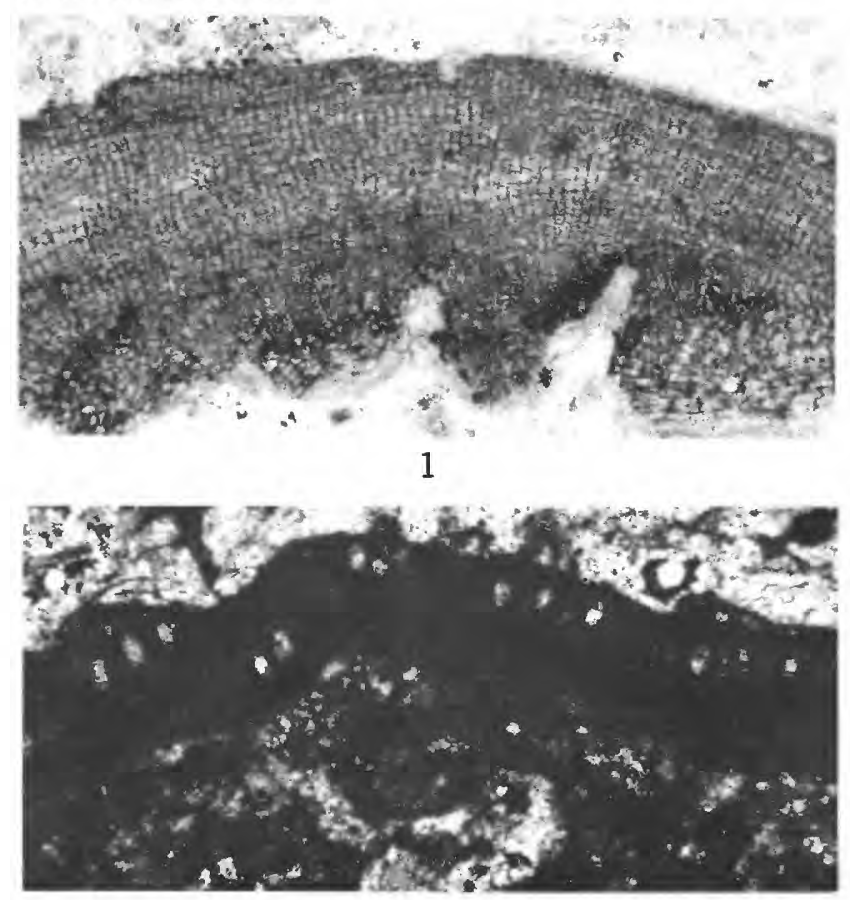

3

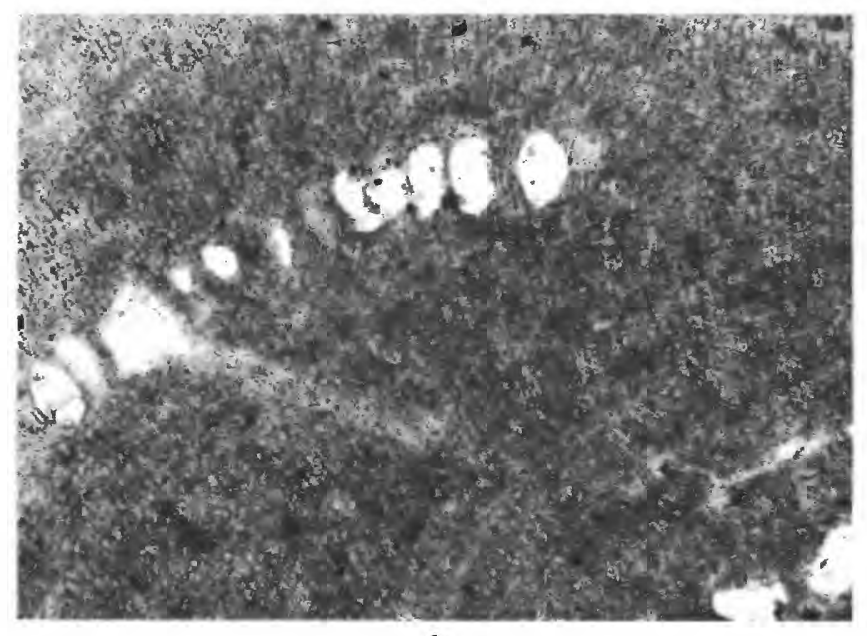

4

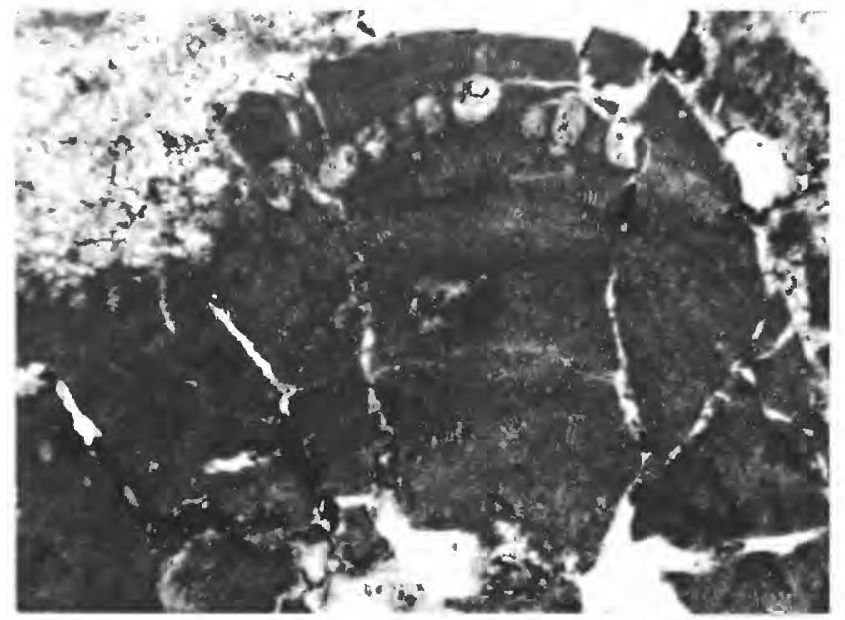

6
PROFESSIONAL PAPER 260 PLATE 268
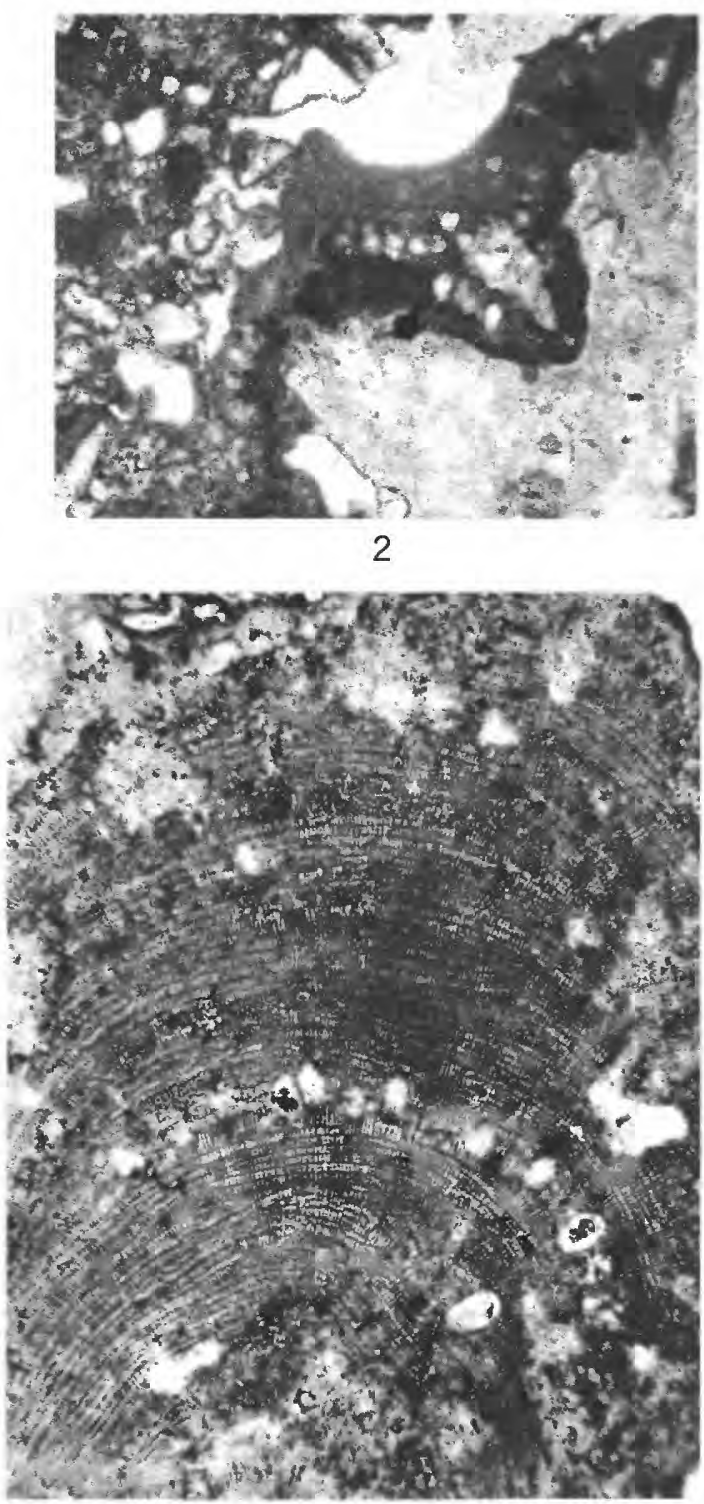

5

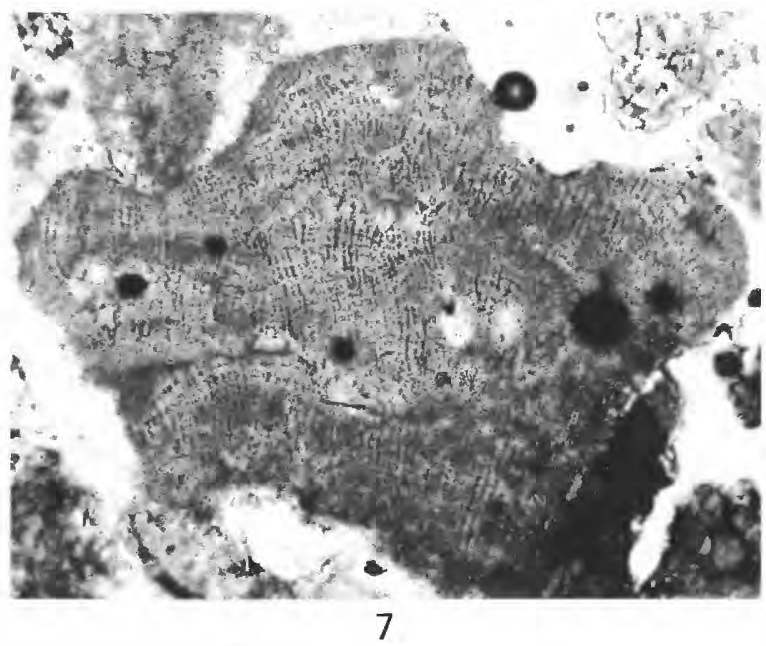




\section{PLATE 269}

Figure 1. Archaeolithothamnium aff. A. affine Howe (p. 921).

Part of a branch showing the vertical cell rows, the curved growth zones, and several layers of sporangia, $\times 38$. Miocene. Eniwetok. USNM 51438.

2. Archaeolithothamnium nummuliticum (Gümbel) Rothpletz (p. 920).

Section through a crust the bottom of which is badly recrystallized, $\times 48$. Several layers of sproangia are visible and some details of the outer perithallic tissue. Late Eocene. Eniwetok. USNM 40810.

3. Archaeolithothamnium marshallensum Johnson, n. sp. (p. 917).

A thin crust, $\times 48$. Consists almost entirely of perithallic tissue with a few sporangia. Miocene. Eniwetok. USNM 51428.

4, 5. Lithothamnium sp. D (p. 924).

4. Fragment of a slender branch with well-defined medullary hypothallus and a slender marginal perithallus, $\times 48$. Miocene. Eniwetok. USNM 40922.

5. A slightly oblique section $(\times 48)$ of another branch showing more details of the marginal perithallus than fig. 4. Early Miocene. Eniwetok. USNM 40804.

6, 7. Lithothamnium sp. C (p. 923).

6. Section of a crust, $\times 48$. Hypothallus thin and irregular with curved rows of cells with a thicker perithallus above. Miocene. Eniwetok. USNM 40802.

7. Specimen, $\times$ 48. Slightly oblique section showing details of hypothallus. Miocene. Eniwetok. USNM 40803. 8. Lithothamnium sp. A (p. 923).

Thin irregular crust, $\times$ 48. Miocene. Eniwetok. USNM 40800 . 


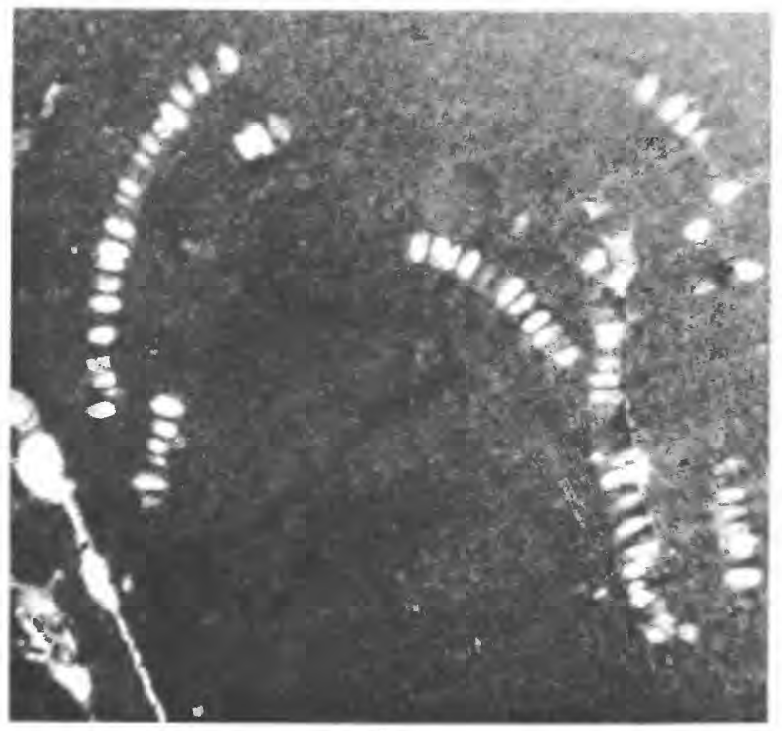

1

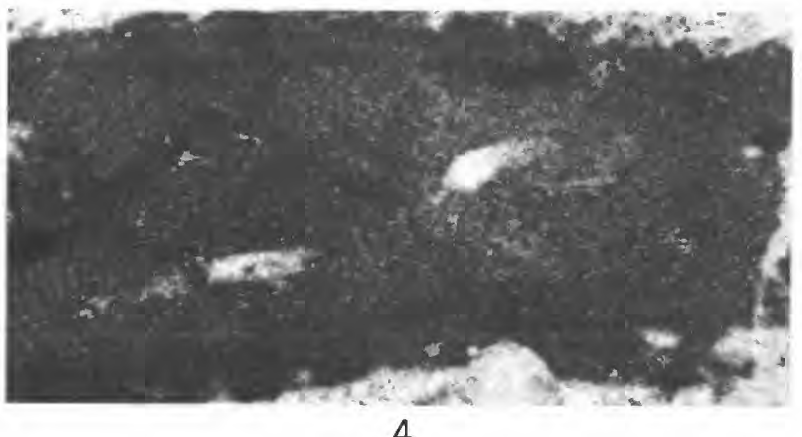

4

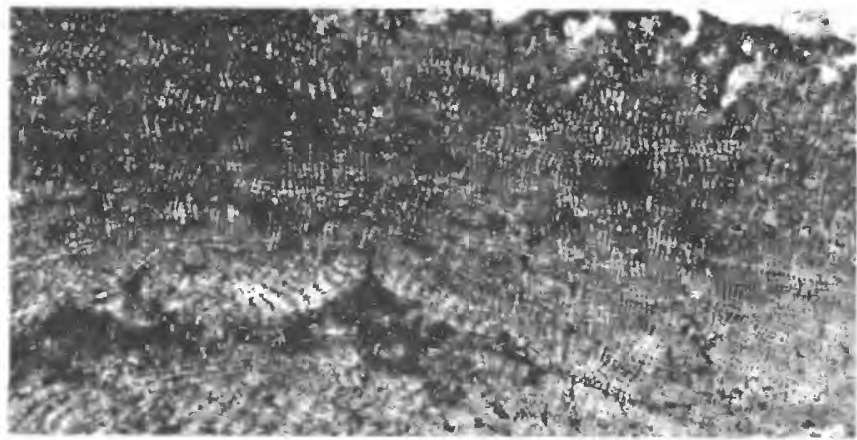
6

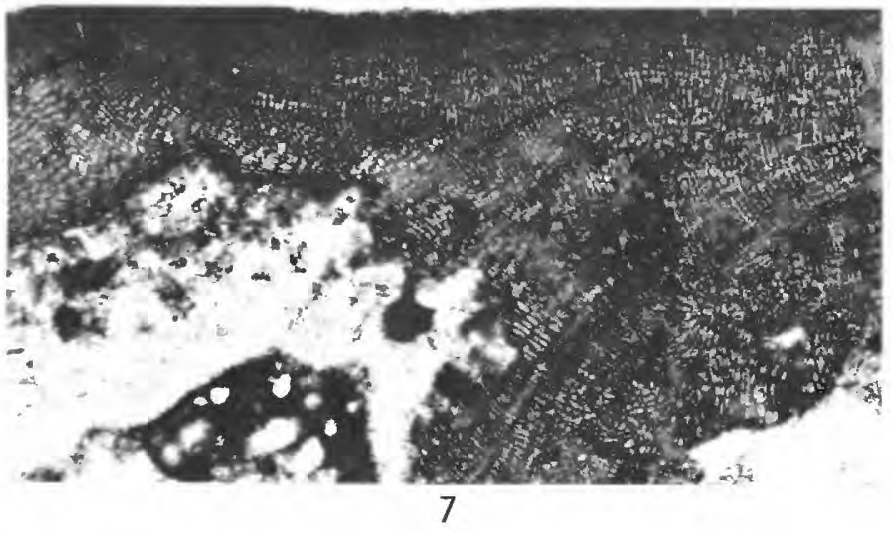

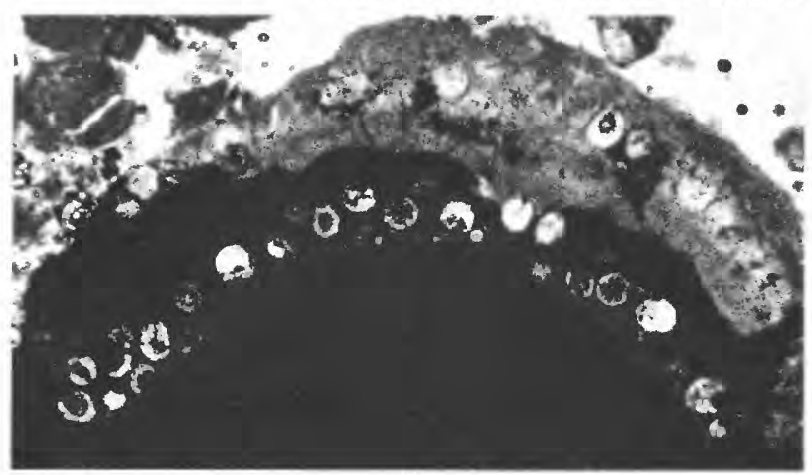

2

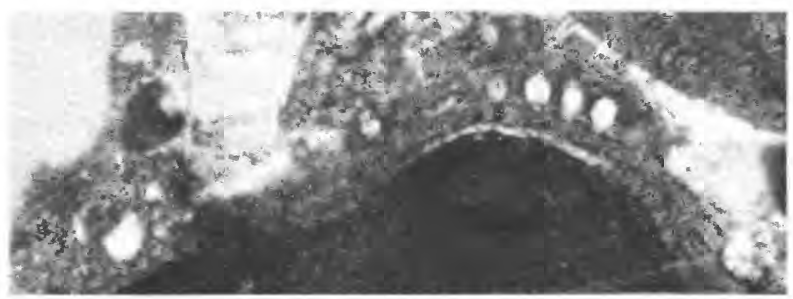

3

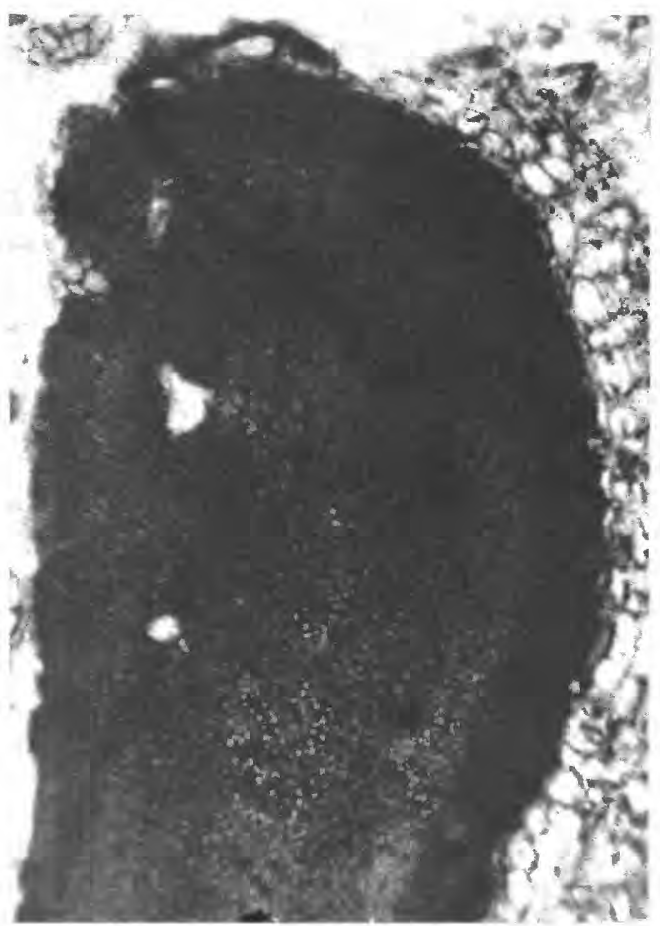

5

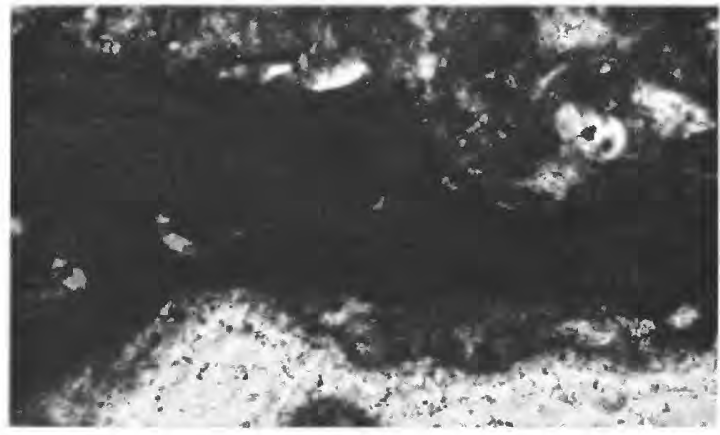

8 


\section{PLATE 270}

FigURE 1. Lithothamnium funafutiense Foslie (p. 924).

Thin crust showing the hypothallus and perithallus, $\times$ 38. Pleistocene. Funafuti. British Museum slide 534.

2. Lithothamnium sp. B (p. 923).

Shows the well-developed hypothallus and the relatively thin perithallus, $\times 95$. Miocene. Eniwetok. USNM 40801.

3, 4. Lithothamnium cf. L. nitidum Foslie (p. 924).

3. Section of a crust with a thin hypothallus of curved rows of cells, a thick perithallus and a conceptacle chamber (near top) having indications of multiple openings in the roof of the conceptacle, $\times 38$. Probably Pleistocene. Kita-Daitō-Jima. Tōhoku University, slide 53.

4. Specimen showing irregular growth zones and a conceptacle chamber with several apertures, $\times 95$. Probably Pleistocene. Kita-Daitō-Jima. Tōhuko University, Aoki coll., slide 196.

5. Mesophyllum cf. M. arakuraensis Ishijima (p. 925).

Section of a large crust with well-developed coaxial hypothallus, a thick perithallus and a conceptacle chamber showing several apertures (upper left), $\times$ 48. Miocene. Eniwetok. USNM 40805.

6. Lithothamnium aff. L. aucklandicum Foslie (p. 923).

Shows irregular growth zones of the perithallic tissue and four conceptacles filled with sporangia, $\times 71$. Pleistocene(?). Kita-Daitō-Jima. Tōhoku University, slide 124.

7. Lithothamnium leptum Johnson and Ferris (p. 923).

Crust with moderately developed hypothallus at the base, and a thicker perithallus above, $\times 48$. Miocene. Eniwetok. USNM 40799. 
GEOLOGICAL SURVEY

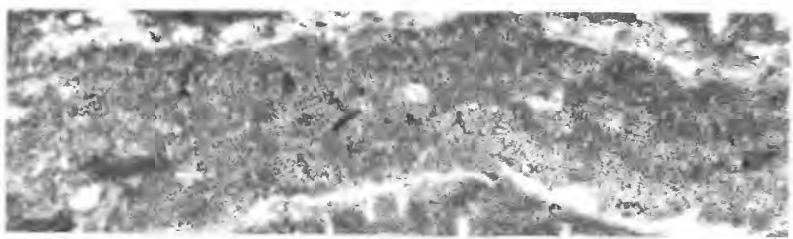

1
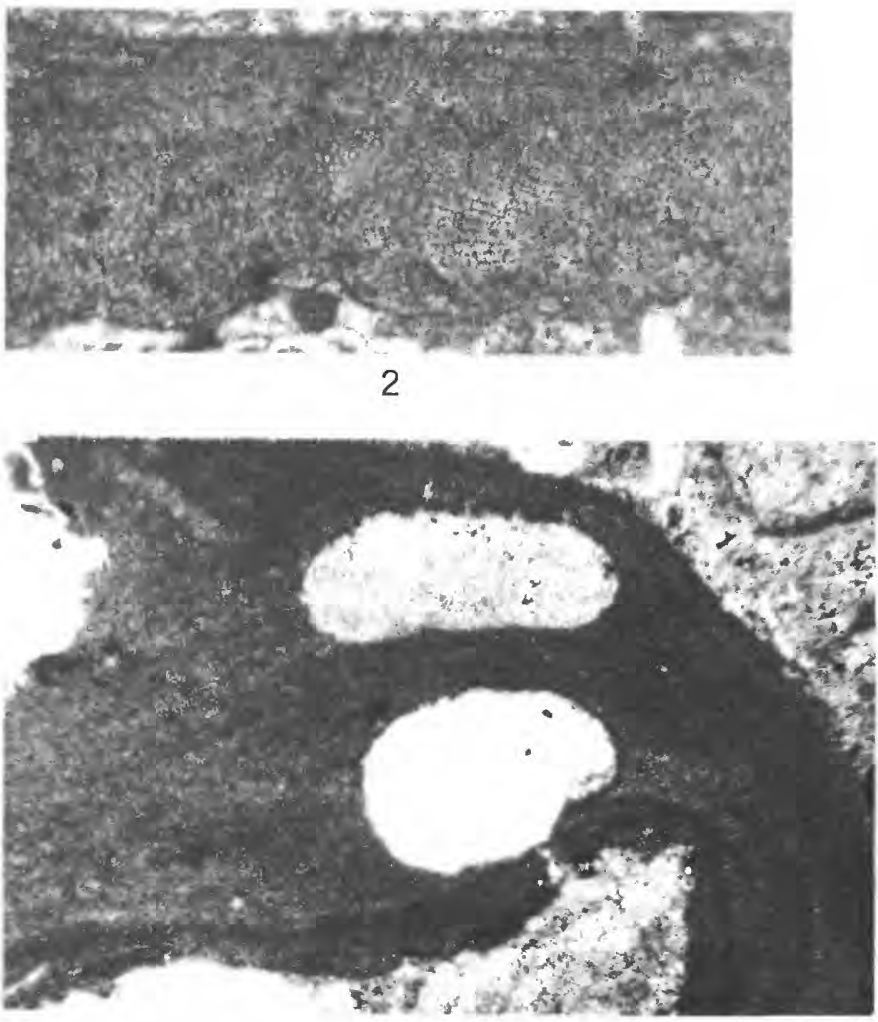

3

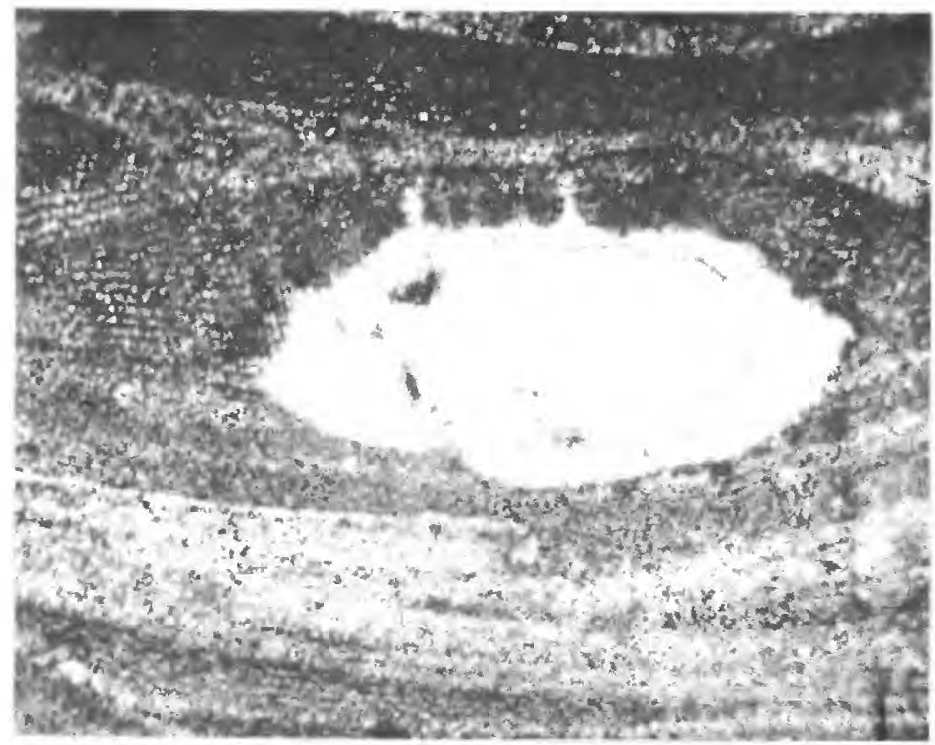

4
PROFESSIONAL PAPER 260 PLATE 270

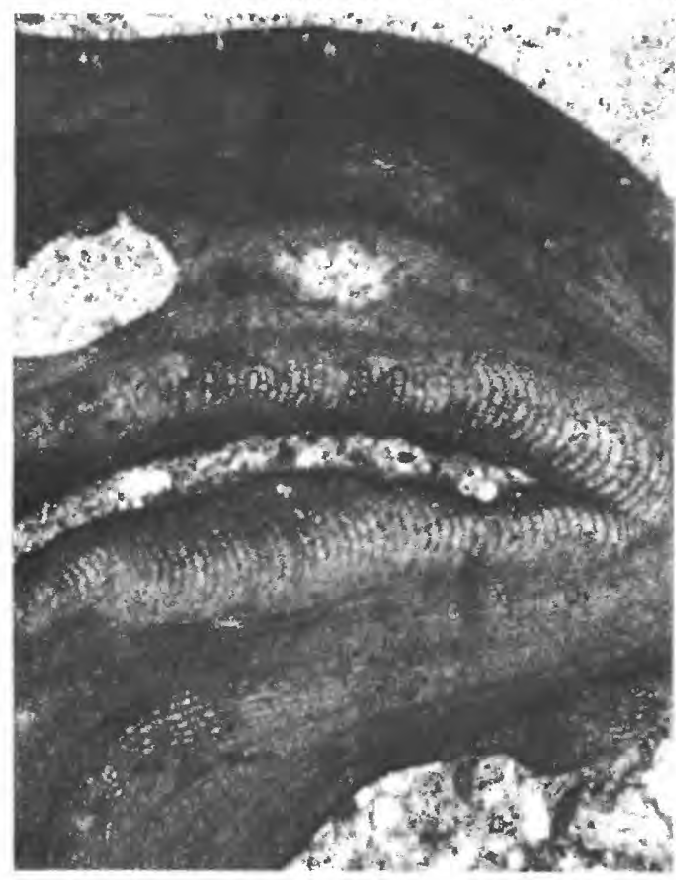

5

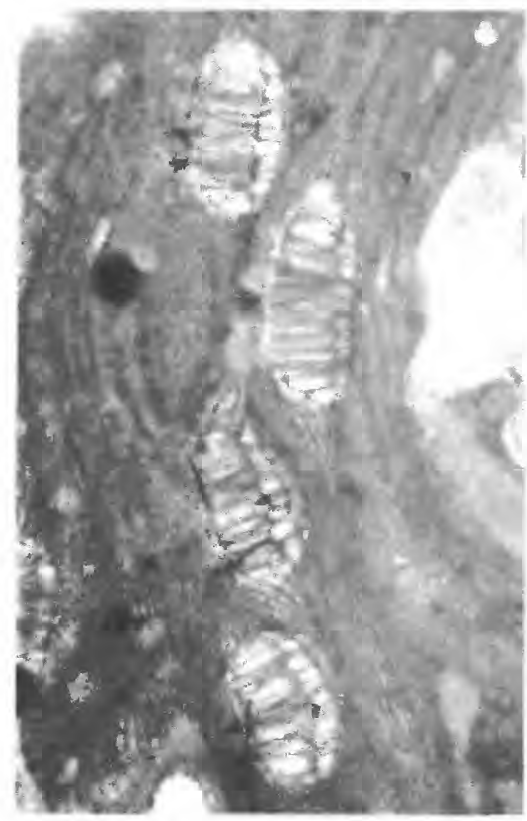

6

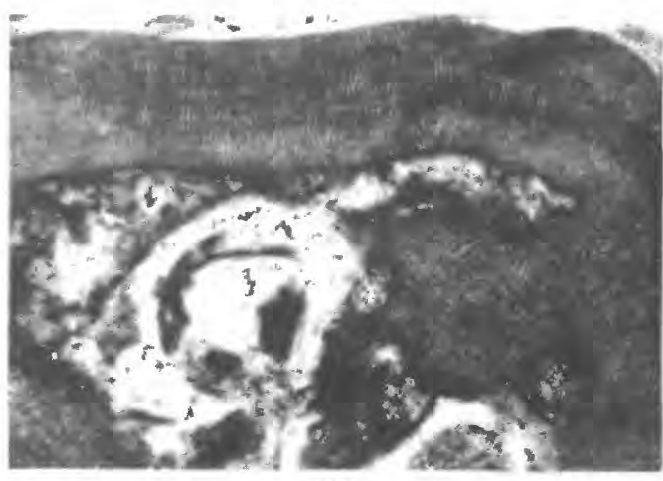

7 


\section{PLA'TE 271}

Figure 1. Mesophyllum ef. M. arakuraensis Ishijima (p. 925).

Slightly recrystallized specimen showing hypothallus and perithallus, $\times 48$. Miocene. Eniwetok. USNM 40806.

2. Mesophyllum ja.ponicum Ishijima (p. 926).

Several specimens intergrown, $\times 48$. A good basal hypothallus occurs near the bottom overlain by a thick perithallus with irregular growth zones. Miocene. Eniwetok. USNM 40809.

3. Mesophyllum sp. A (p. 926).

Slightly oblique section of a crust with a well-developed basal hypothallus and a thick perithallus composed of a number of irregular growth zones, $\times 48$. Miocene. Eniwetok. USNM 40808.

4. Mesophyllum ef. M. savornini Lemoine (p. 926).

Section of a badly recrystallized branch containing three cavities of conceptacle chambers, $\times 48$. Miocene. Eniwetok. USN M 40944.

5. Mesophyllum pulchrum (Foslie) Lemoine (p. 927).

Section of badly recrystallized branch with thick irregular growth zones and several conceptacle chambers, $\times 38$. Pleistocene. Funafuti. British Museum slide 688.

6. Mesophyllum robustum Johnson, n. sp. (p. 926).

Section of a crust showing a well-developed coaxial hypothallus and a thick irregular perithallus with pronounced growth zones, $\times 95$. Several conceptacles with traces of the sporangia are present. Late Eocene. Eniwetok. Holotype USNM 40812. 
GEOLOGICAL SURVEY
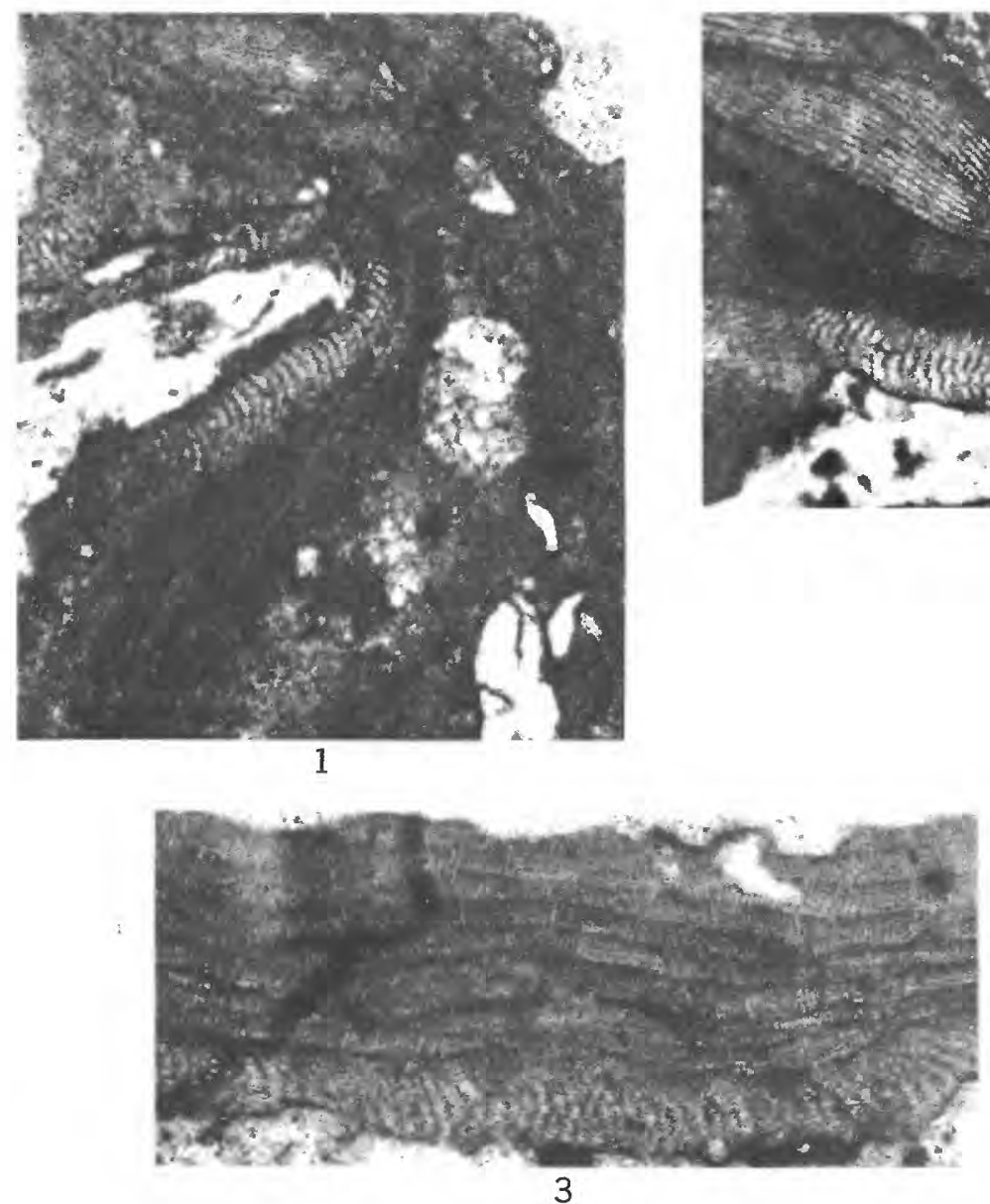

PROFESSIONAL PAPER 260 PLATE 271
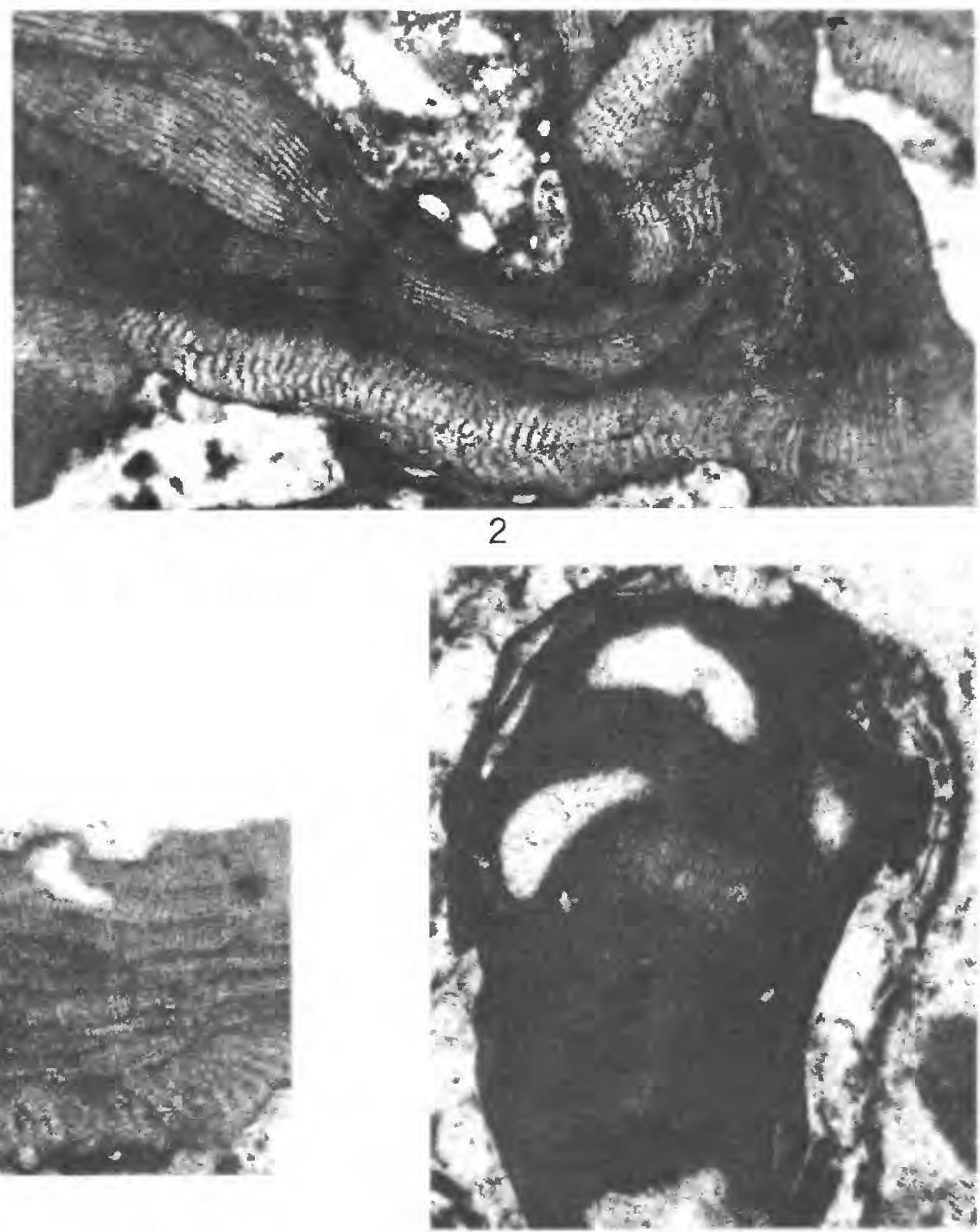

4

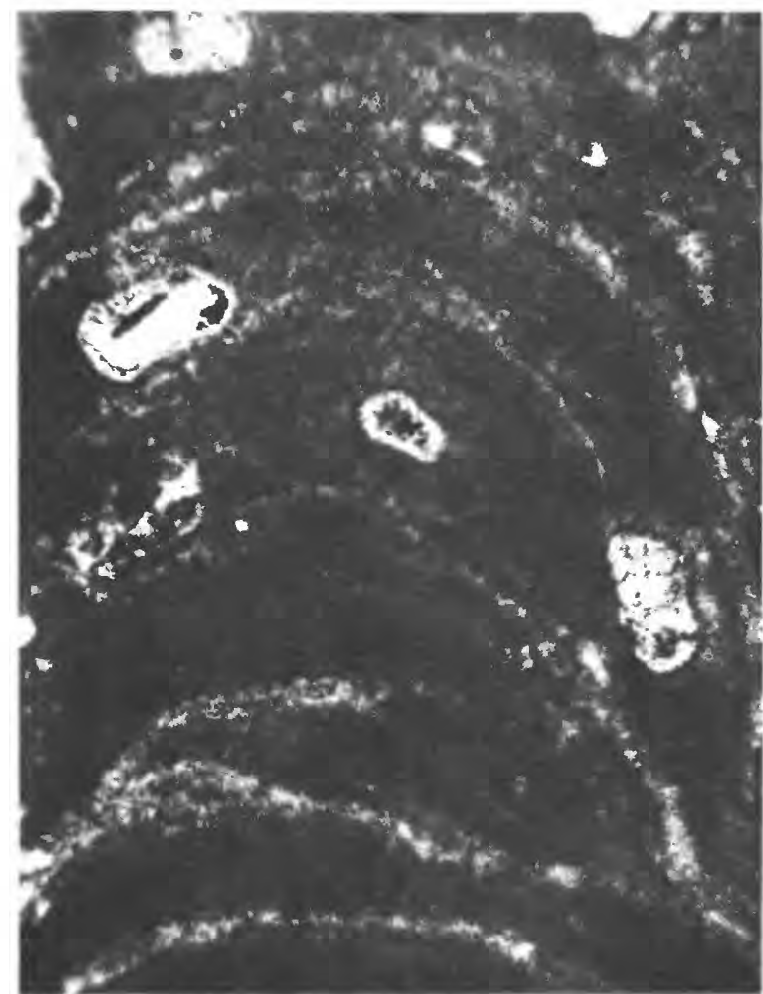

5

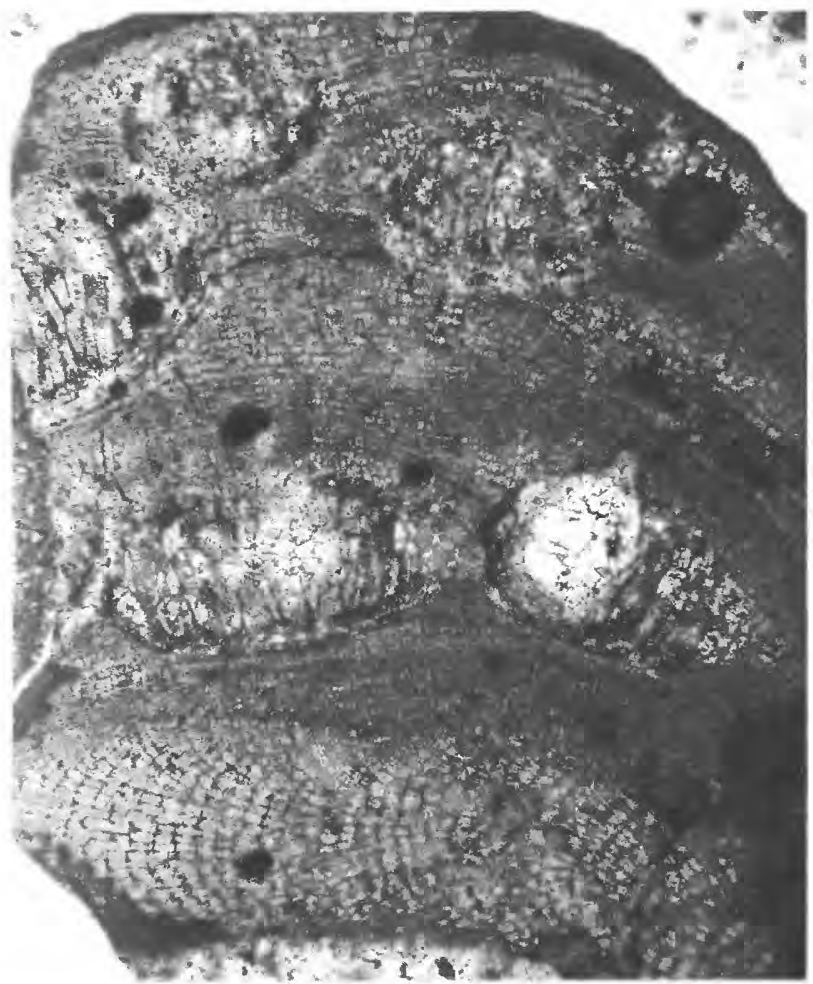

6 
PLATE 272

Figdre 1. Lithophyllum cf. L. lingusticum Airoldi (p. 929).

A thin crust $(\times 48)$ composed of a well-developed hypothallus with a thin perithallus. Late Eocene. Eniwetok. USNM 40814.

2, 3. Lithophyllum hanzawae, Johnson n. sp., (p. 928).

Pleistocene (?), Kita-Daitō-Jima. Holotype, Tōhoku University slide, Aoki colln. 141.

2. Detail of the hypothallus, perithallus, and conceptacle chambers, $\times 95$.

3. General view showing the thick regular perithallic tissue and the numerous conceptacle chambers, $\times 38$. The large single apertures of some of the conceptacles are plainly visible.

4. Mesophyllum eniwetokensum Johnson, n. sp. (p. 925).

Slightly oblique section of a crust formed of several superimposed thalli, $\times 48$. Shows growth zones and several conceptacle chambers with traces of the sporangia. Miocene. Eniwetok. Holotype, USNM 40807.

5. Mesophyllum sp. B. (p. 927).

Section of a branch giving details of the tissue, $\times 48$. Miocene. Eniwetok. USNM 40811.

6. Mesophyllum erubescens (Foslie) Lemoine (p. 926).

A part of the tissue of a branch, $\times 38$. Pleistocene or Recent. Funafuti. British Museum slide 615 .

7. Lithophyllum kladosum Johnson (p. 931).

Section showing branching, $\times 48$. Miocene. Eniwetok. USNM 40924. 
GEOLOGICAL SURVEY
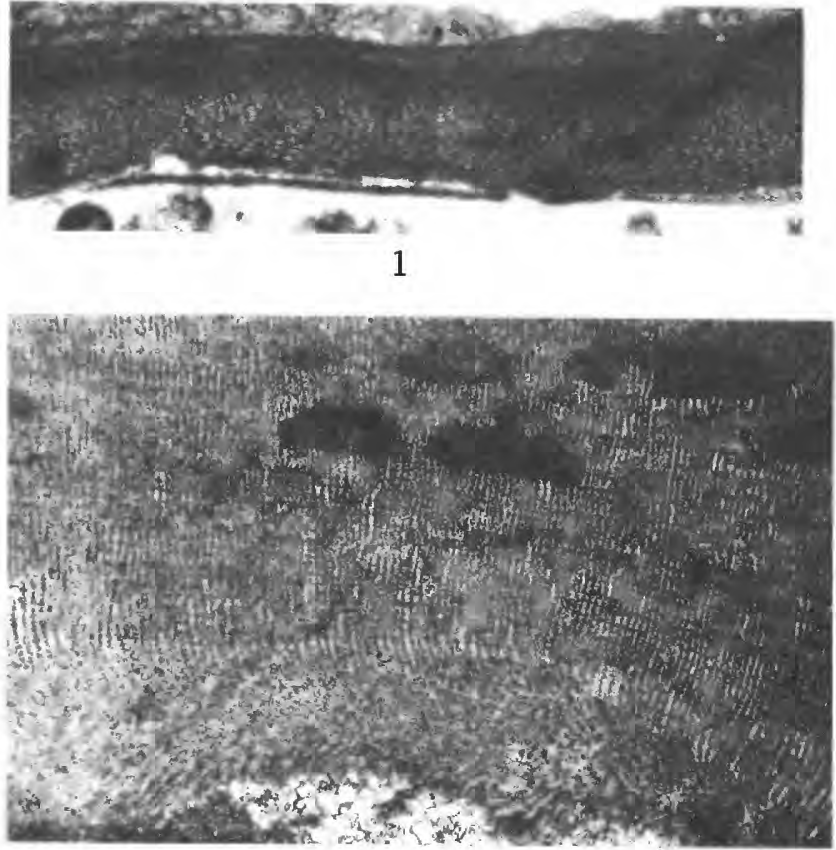

2

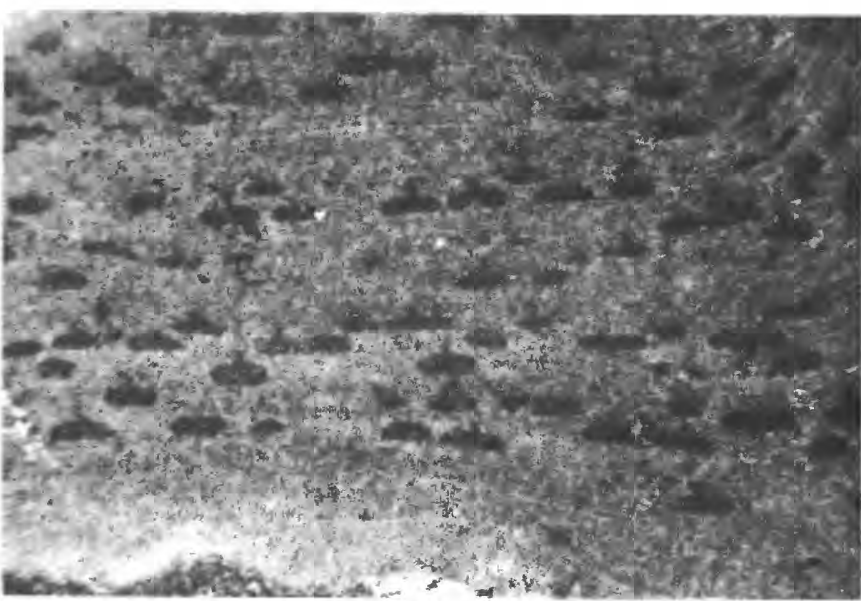

3

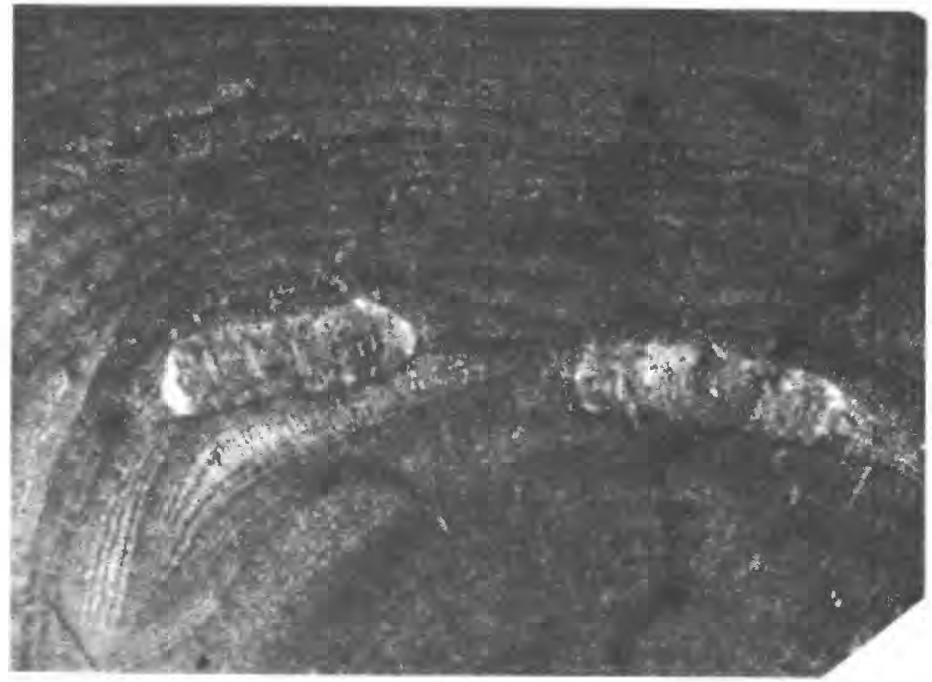

4
PROFESSIONAL PAPER 260 PLATE 272

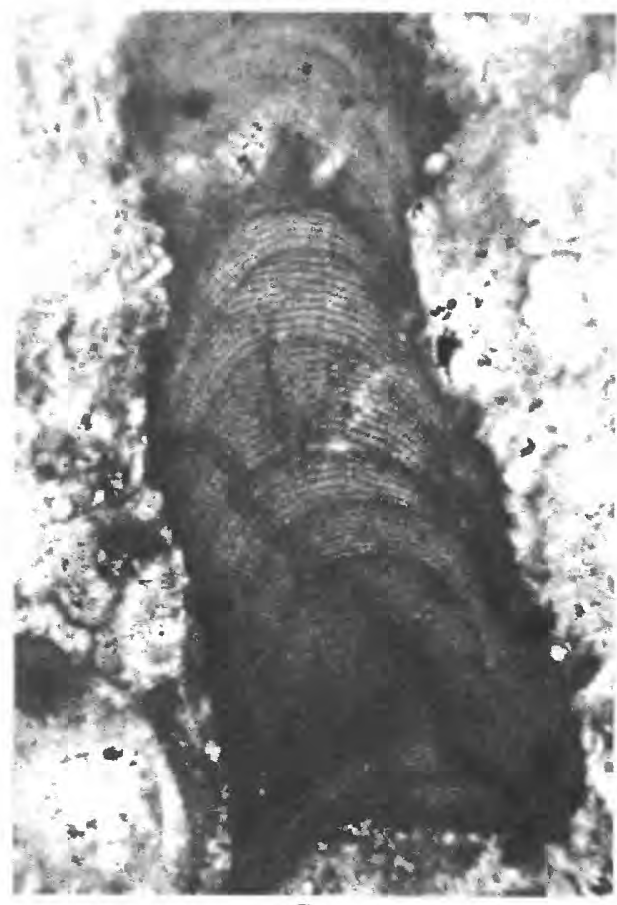

5

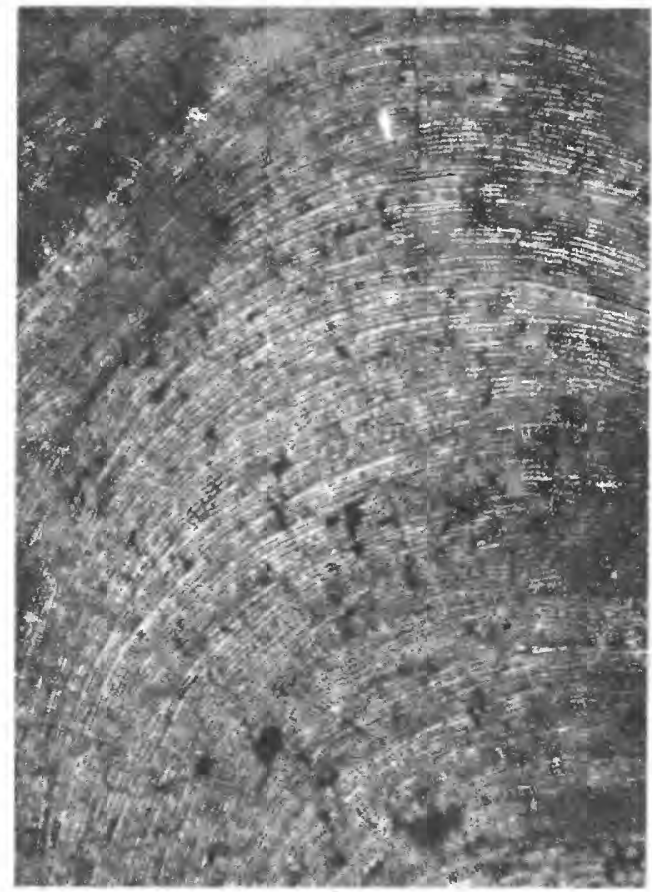

6

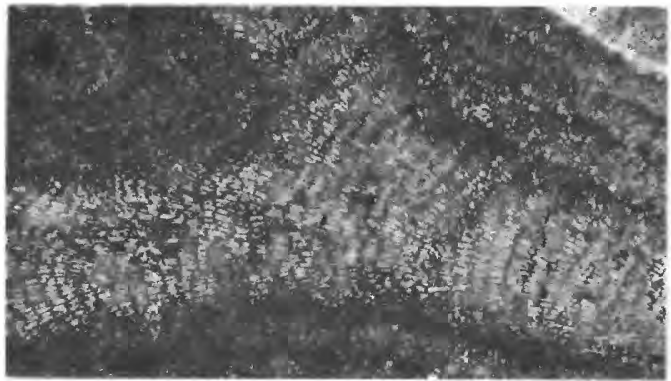




\section{PLATE 273}

Figure 1. Lithophyllum acanthinum Foslie (p. 928).

Badly frayed crust showing well-developed hypothallus and perithallus, $\times 95$. Pliocene or Pleistocene. KitaDaitō-Jima. Tōhoku University slide 656.

2. Lithophyllum quadratum Ishijima (p. 930).

Section of a crust composed of several superimposed thalli, $\times 38$. Each consists of a thin hypothallus and a thicker perithallus with regular tissue. Pleistocene(?). Kita-Daitō-Jima. Tōhoku University slide 63.

3, 4. Lithophyllum stefaninii Airoldi (p. 930).

Probably Pliocene-Pleistocene. Kita-Daitō-Jima. Tōhoku University slides 62 and 661.

3. Thin irregular crust showing the regular perithallic tissue and poorly developed hypothallus, $\times 38$.

4. Slightly oblique section of crust with well-developed hypothallus, $\times 38$.

5, 6. Lithophyllum samoense Foslie (p. 930).

Pleistocene (?). Kita-Daitō-Jima.

5. Section through a thick crust showing several conceptacle chambers, $\times 71$. Tōhoku University slide 61 .

6. Section of thin crust with a thin hypothallus at the base and a thick perithallus with several conceptacle chambers, $\times 38$. Tōhoku University slide 256 .

7. Lithophyllum thikombian Johnson and Ferris (p. 930).

Fragment showing well-developed coaxial hypothallus and parts of a narrow perithallus, $\times 95$. Probably Miocene. Kita-Daitō-Jima. Tōhoku University slide 656 . 
GEOLOGICAL SURVEY

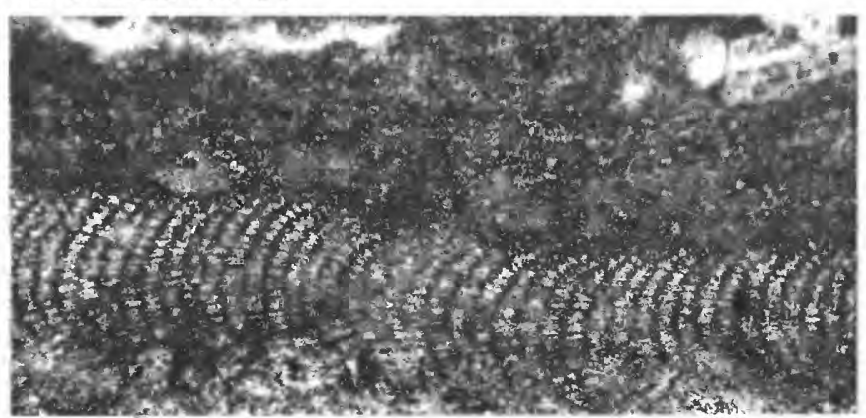

1
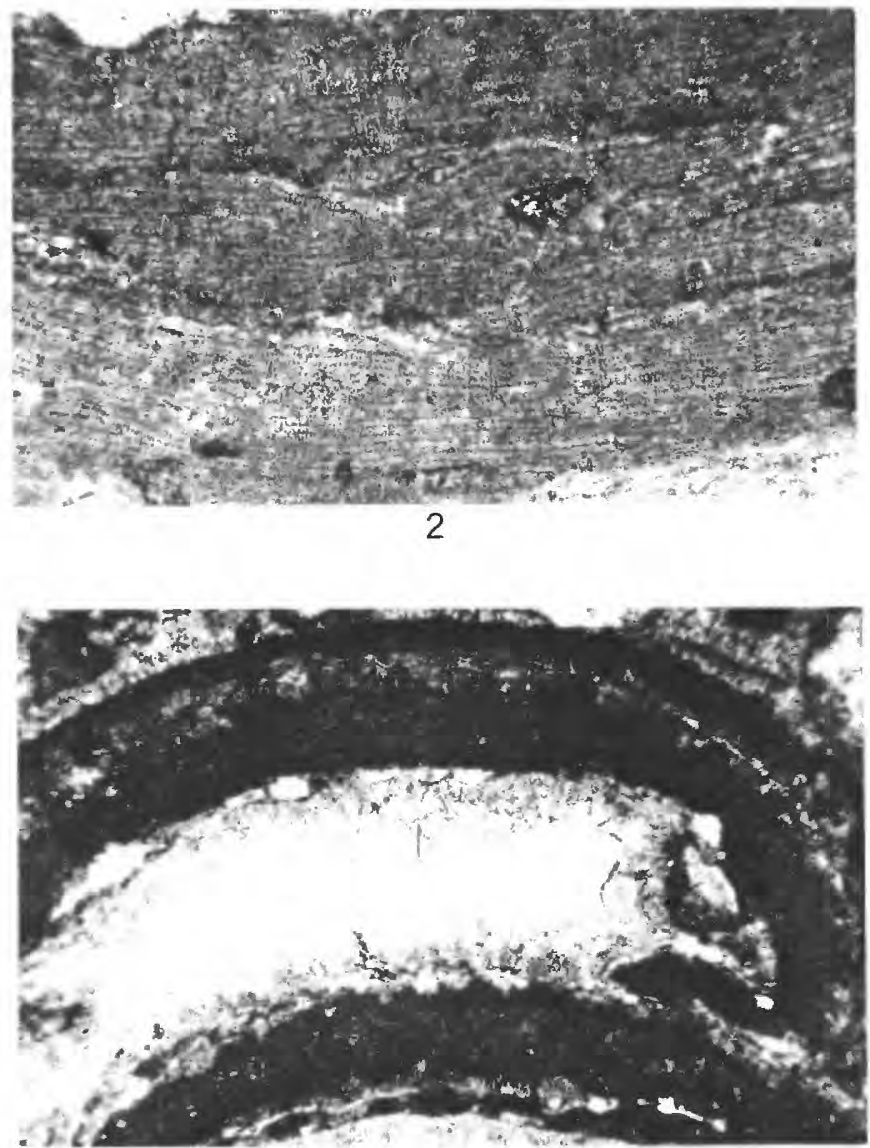

4

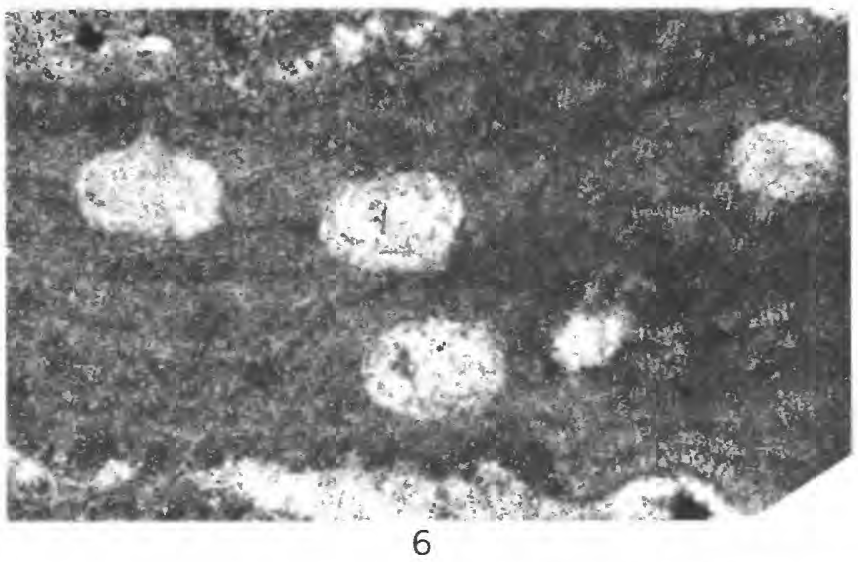

PROFESSIONAL PAPER 260 PLATE 273

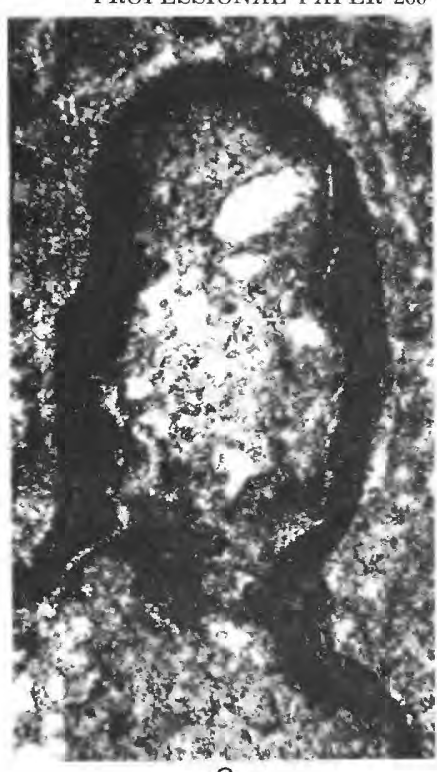

3

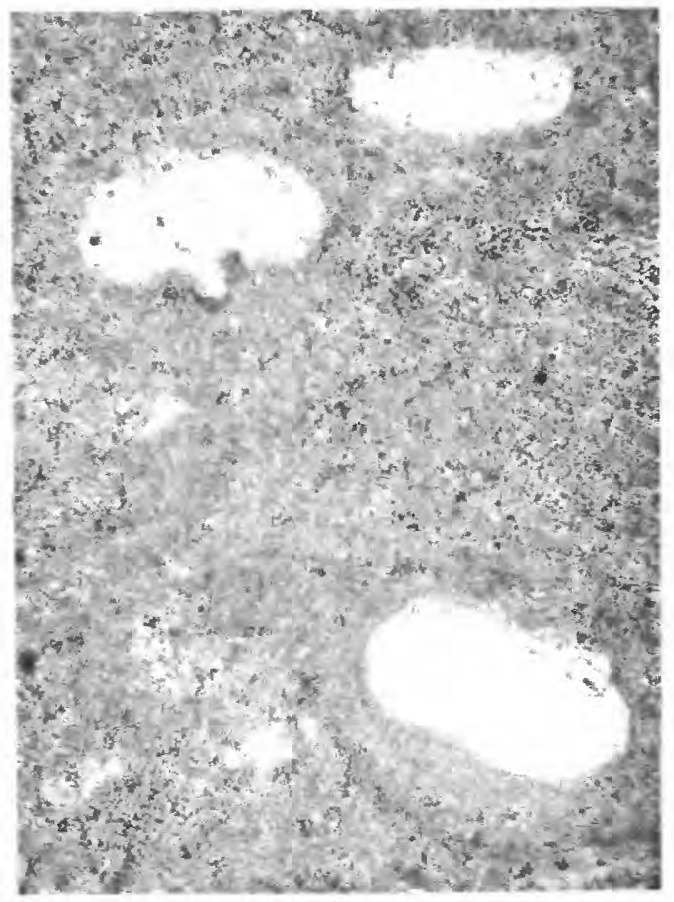

5

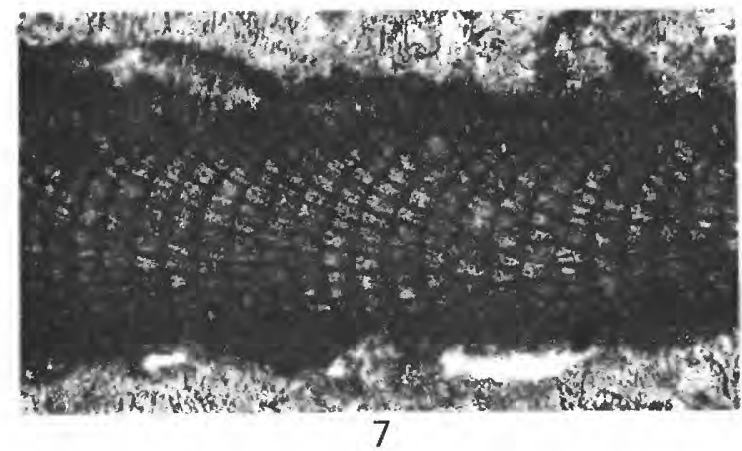




\section{PLATE 274}

FIGURE 1. Lithophyllum okamurae Foslie (p. 930).

Section of a fertile crust with thick perithallic tissue and numerous small conceptacle chambers, $\times 38$. Pleistocene or Recent. Kita-Daitō-Jima. Tōhoku University slide 176.

2, 3. Lithophyllum cf. L. kotschyanum Unger (p. 931).

Pleistocene (?). Kita-Daitō-Jima. Tōhoku University slide 73.

2. Section of a large and partly recrystallized branch, $\times 38$. Numerous growth zones and several conceptacle chambers are shown.

3. Slightly oblique section of branch showing transition from medullary hypothallus to marginal perithallus as well as pronounced growth zones and several small conceptacle chambers, $\times 38$.

4, 5. Lithophyllum kladosum Johnson (p. 931).

Miocene. Eniwetok.

4. Section of a typical long slender branch bearing two conceptacles along the outer margin, $\times 48$. USNM 40816 .

5. Specimen showing the development of branches, $\times 48$. USNM 40815 . 
GEOLOGICAL SURVEY

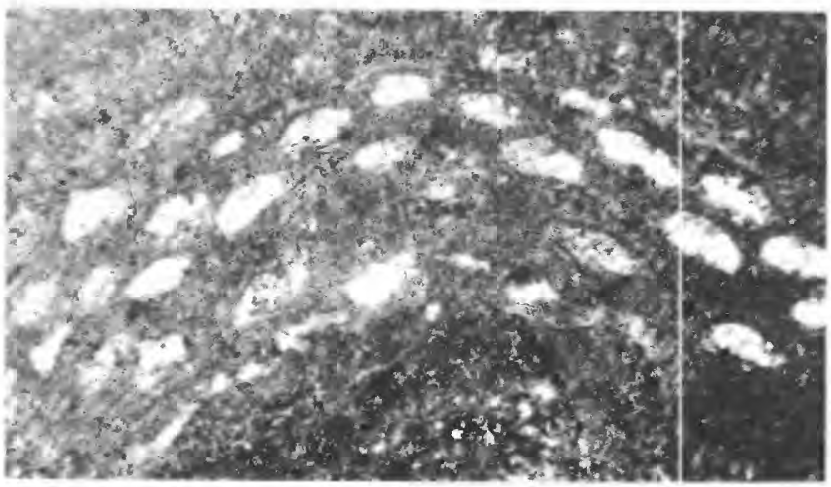

1

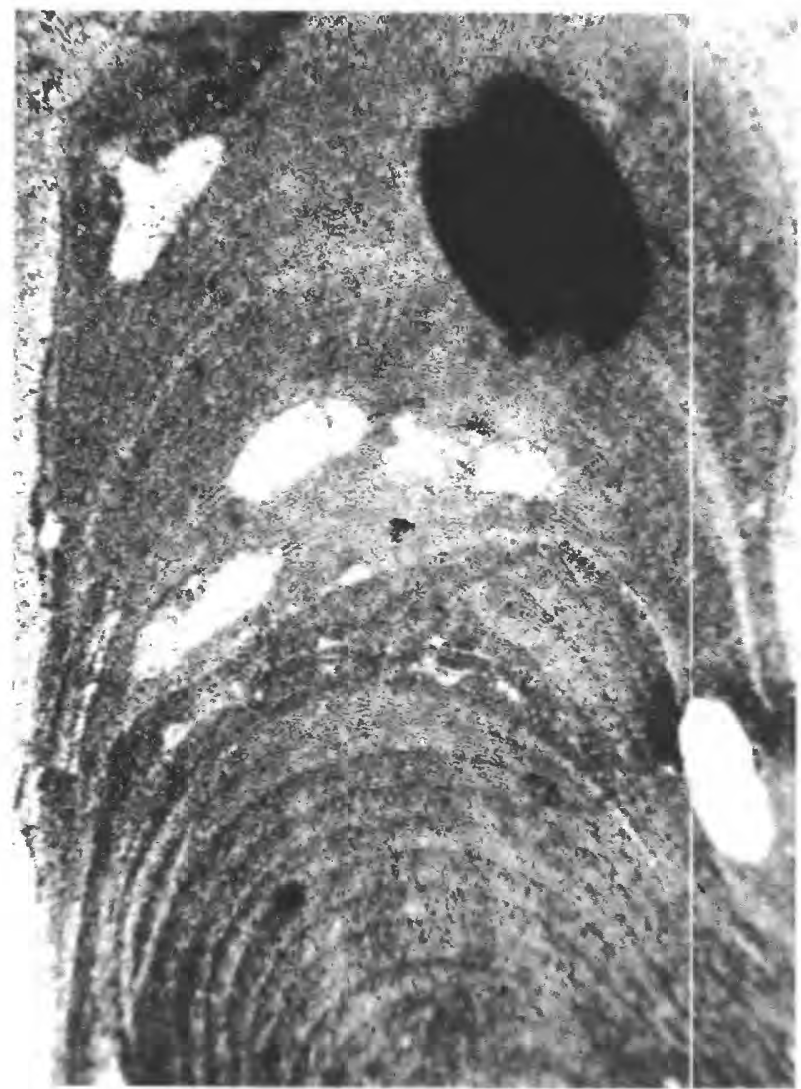

2

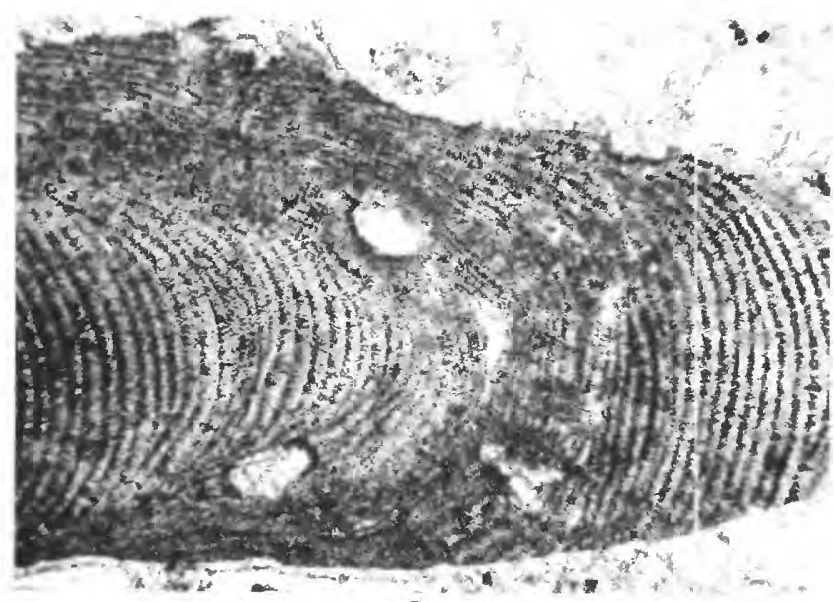

PROFESSIONAL PAPER 260 PLATE 274

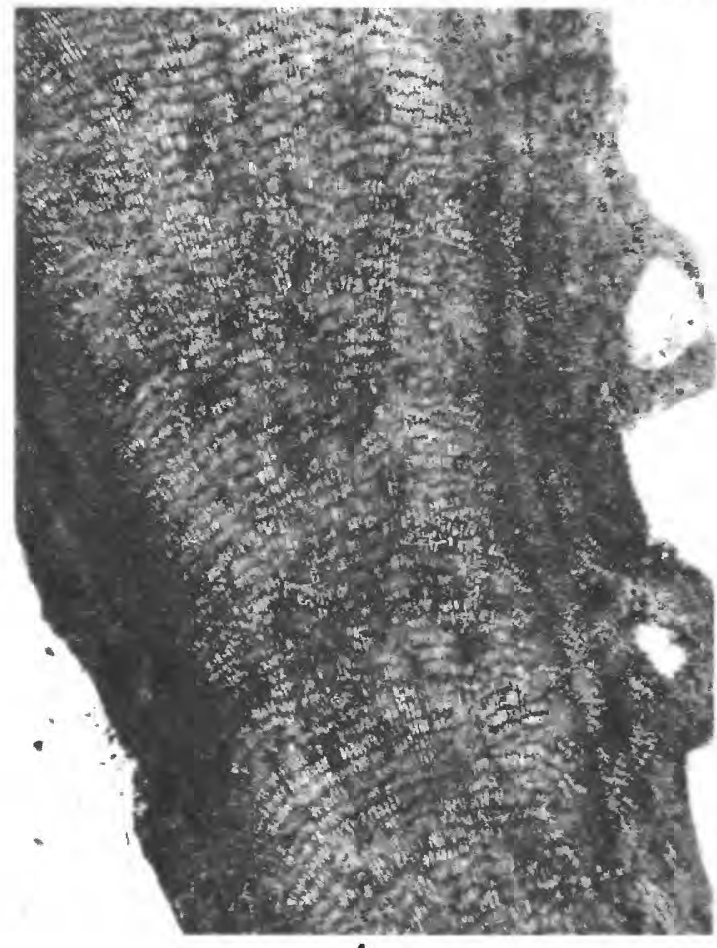

4

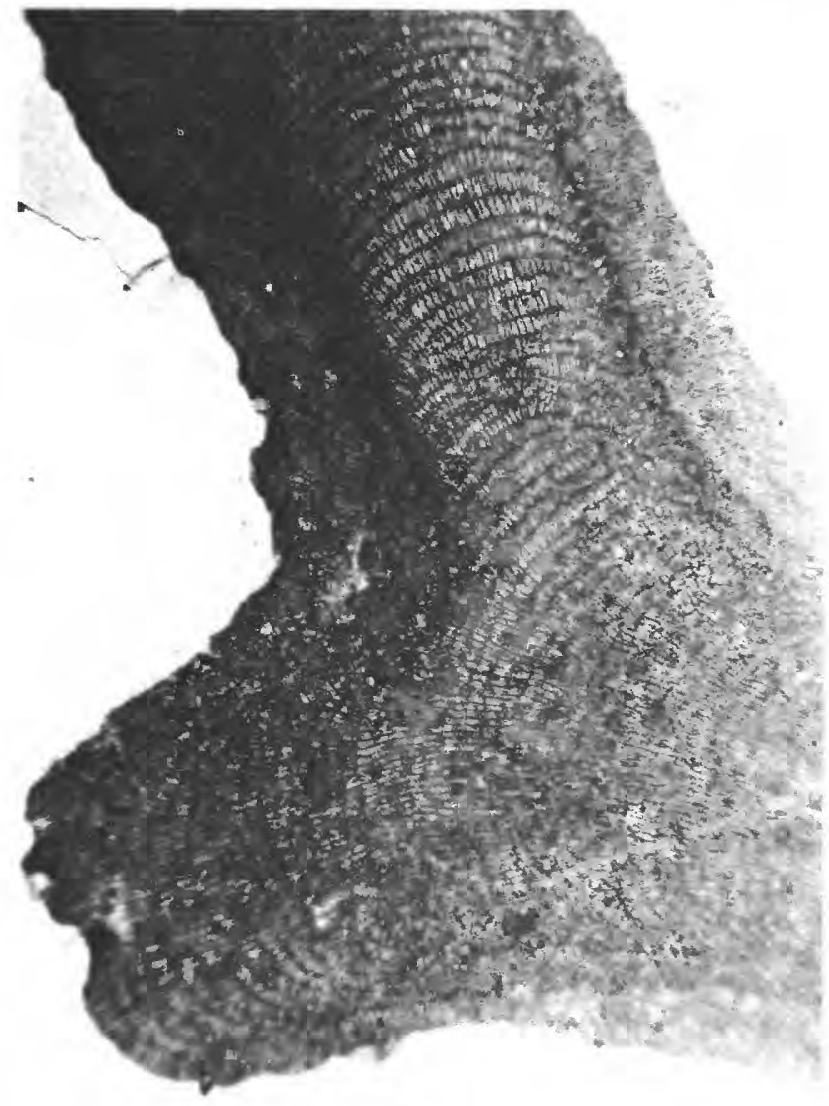

5 
PLATE 275

Figdres 1, 2. Porolithon aequinoctiale (Foslie) Foslie (p. 934).

Pleistocene(?), and Recent. Eniwetok.

1. Section of perithallic tissue perpendicular to the cell layers showing the clusters of megacells, $\times 95$. USNM 40817.

2. Section parallel to the cell layers showing the megacell clusters in ground plan, $\times 95$. USNM 40818 .

3, 4. Porolithon marshallense Taylor (p. 935).

Recent. Eniwetok.

3. Oblique section through the tip of a branch showing the medullary hypothallus, and the marginal perithallic tissue with numerous clusters of megacells, $\times 48$. CSNM 40819 .

4. Section through branch showing details of tissue $\times 48$. USNM 40940 .

5. Lithophyllum profundum Johnson (p. 931).

Branch with a marginal conceptacle, $\times$ 48. Miocene. Eniwetok. USNM 40913.

6. Goniolithon myriocarpon Foslie (p. 932).

Recent and Miocene. Eniwetok. Section of crust with a thin basal hypothallus and a thicker perithallus, $\times 48$. Numerous megacells are distributed throughout penthallic tissue. USNM 40820.

7. Goniolithon fosliei (Heydrich) Foslie (p. 932).

Thin crust, somewhat recrystallized, with a well-developed coaxial hypothallus and a thicker perithallus, $\times 95$. The small megacells are not clearly shown. Recent and Pleistocene(?). Funafuti. British Museum slide 665. 
GEOLOGICAL SURVEY

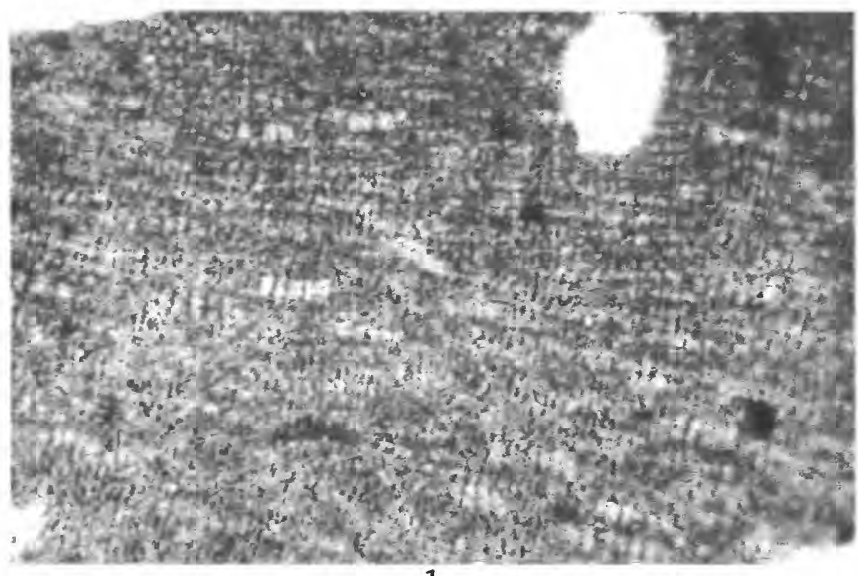

1

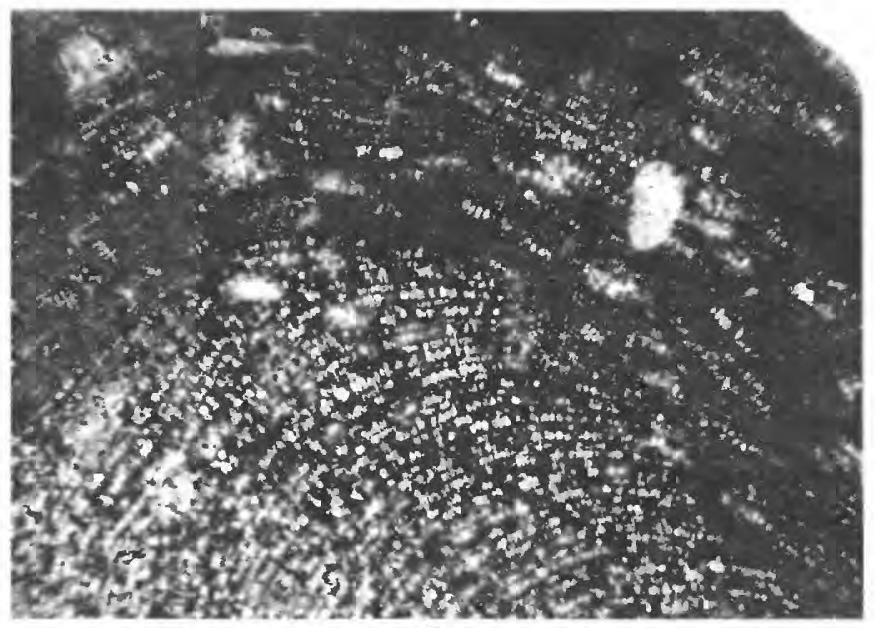

3
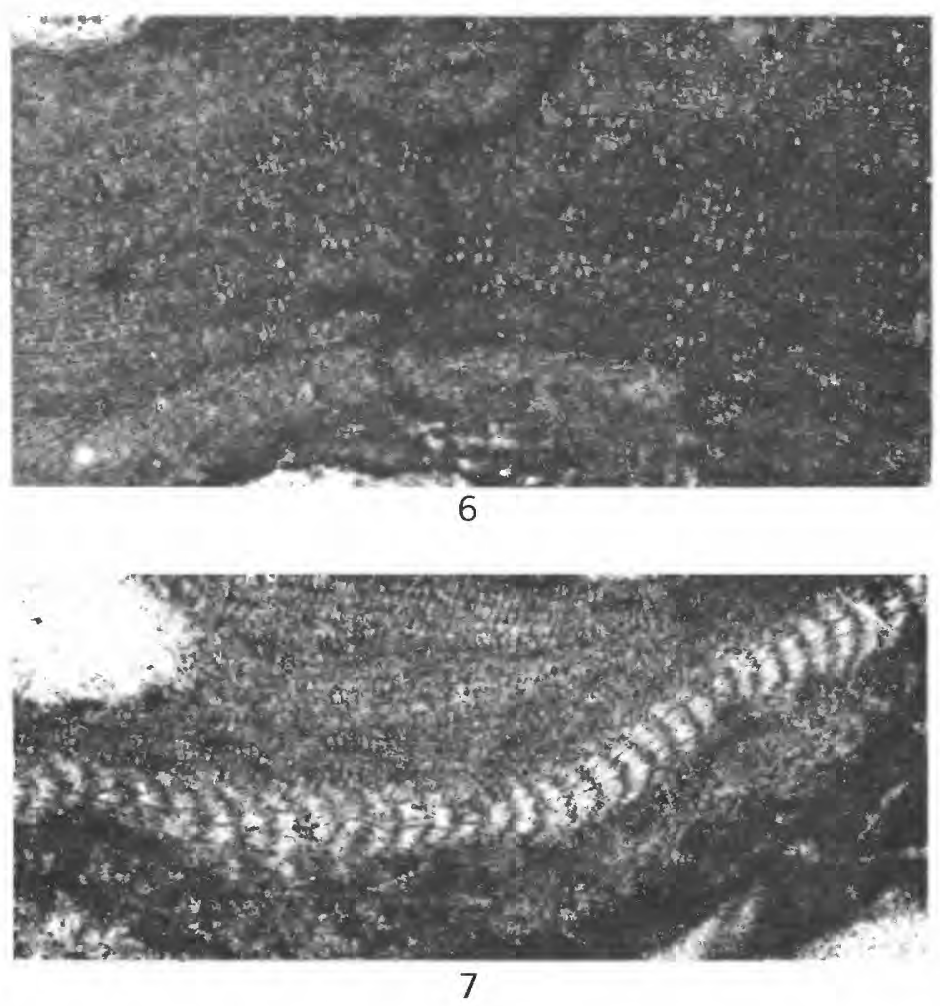

PROFESSIONAL PAPER 260 PLATE 275

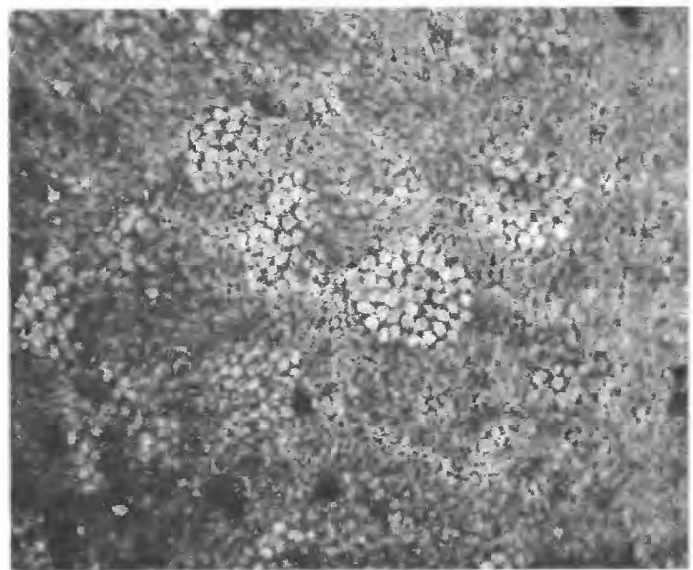

2

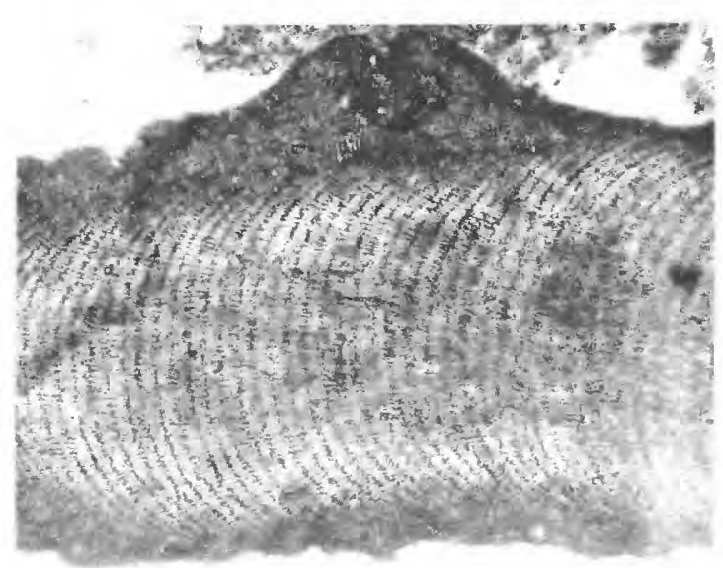

5

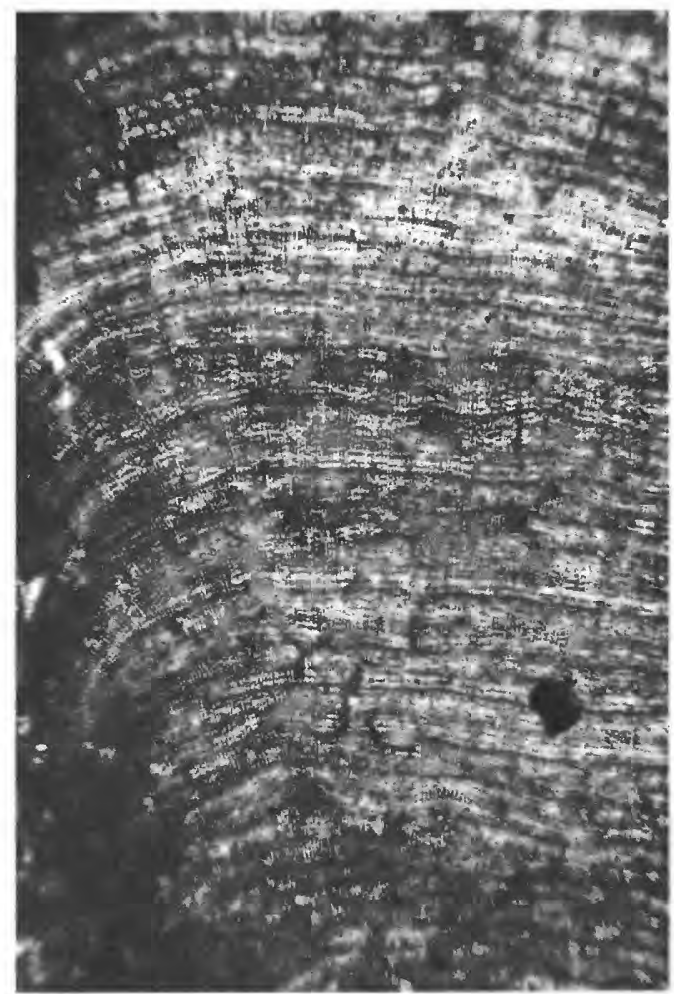

4 


\section{PLATE 276}

Figures 1, 2. Lithoporella antiquitas Johnson, n. sp. (p. 937).

Vertical sections of fertile specimens showing the long canal leading to the conceptacle opening, $\times 95$. Miocene. Eniwetok. Holotype USNM 40825.

3, 4. Lithoporella longicella Johnson n. sp. (p. 937).

Nearly vertical sections showing crusts formed of numerous thalli superimposed, $\times 48$. Recent or Pleistocene(?). Eniwetok. Holotype USNM 40822.

5. Lithoporella sp. B (p. 937). Section, $\times$ 48. Miocene. Eniwetok. USNM 40824.

6. Lithoporella cf. L. crassa Ishijima (p. 936). The section cuts a number of superimposed thalli at various angles, $\times 48$. Recent or Pleistocene(?) Eniwetok. USNM 40821. 
GEOLOGICAL SURVEY
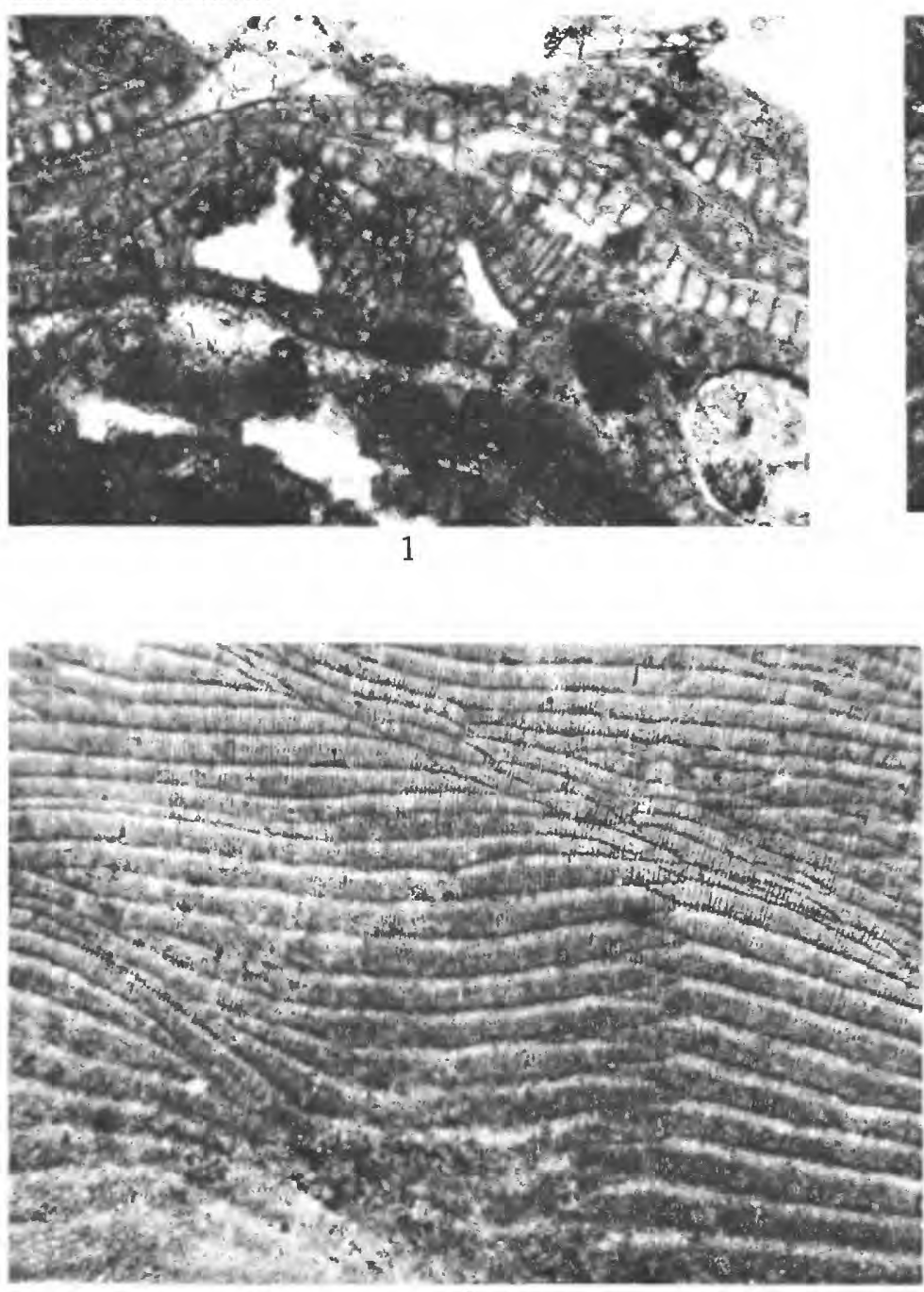

3

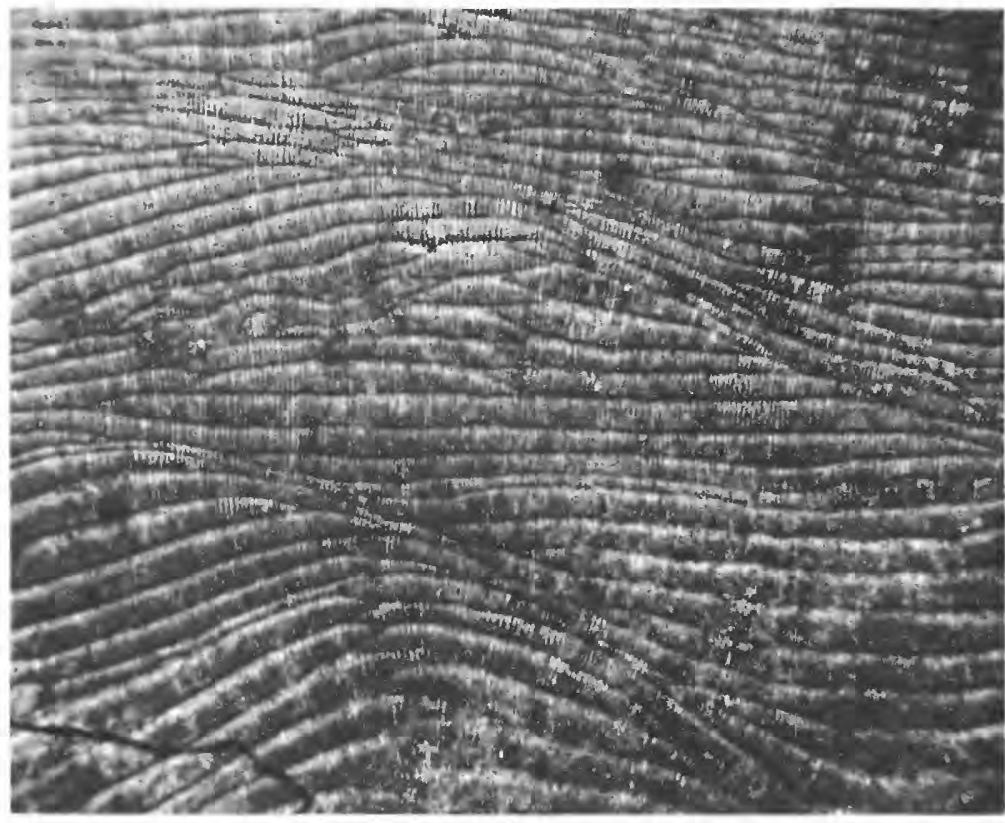

4
PROFESSIONAL PAPER 260 PLATE 276

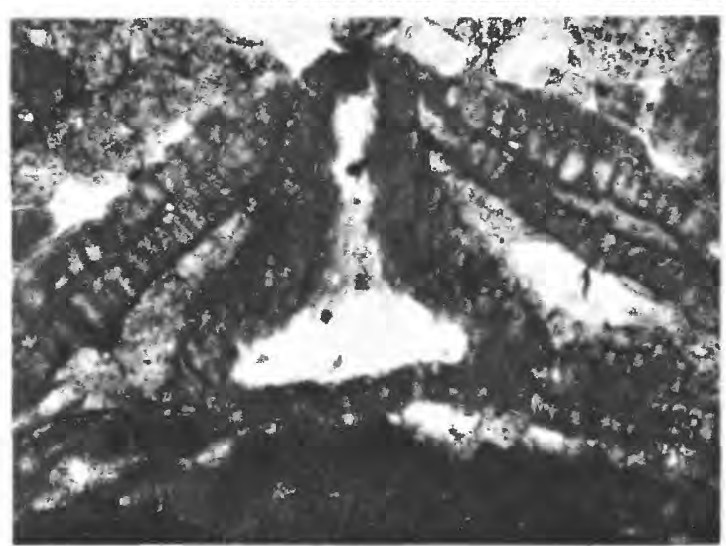

2

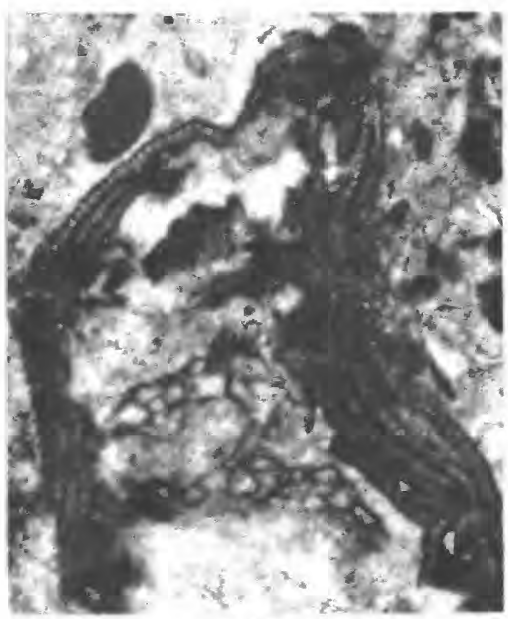

5

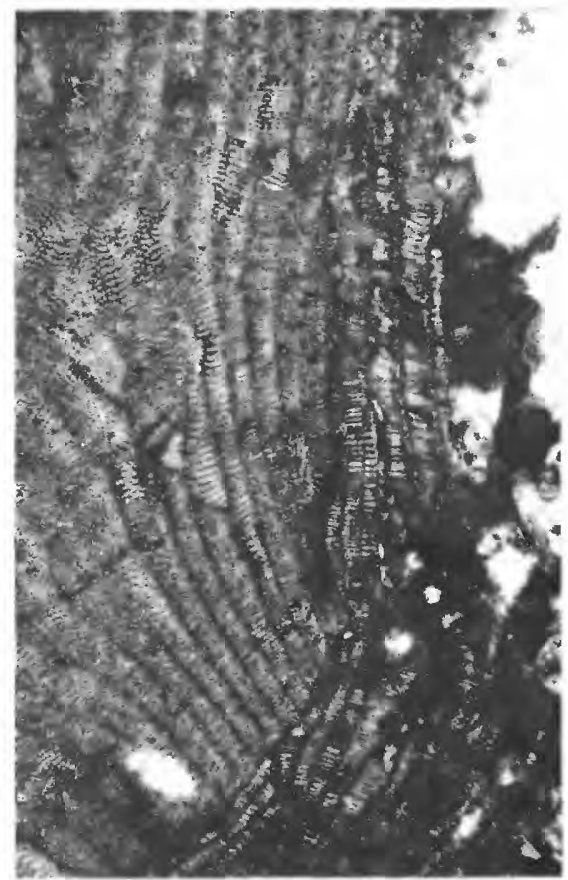




\section{PLATE 277}

FigdRE 1. Corallina sp. B (p. 941).

Two segments, $\times$ 48. Miocene. Eniwetok. USNM 40832.

2, 3. Corallina marshallensis Johnson, n. sp. (p. 941).

Miocene. Eniwetok.

2. Two segments with a node between, $\times 48$. Holotype USNM 40829 .

3. A single segment, $\times 48$. USNM 40830 .

4. Corallina sp. C (p. 941).

Nearly complete segment, $\times 48$. Miocene. Eniwetok. USNM 40833.

5. Corallina sp. A (p. 941).

Worn segment, $\times 48$. Miocene, Eniwetok. USNM 40831.

6. Amphiroa sp. A (p. 939).

Long segment somewhat abraded, $\times$ 38. Late Eocene. Eniwetok. USNM 40945.

7. Amphiroa sp. B (p. 939).

Fragment showing alternating layers of long and short cells, $\times$ 95. Late Eocene. Eniwetok. USNM 40914.

8, 9. Amphiroa fortis Johnson, n. sp. (p. 939).

Late Eocene. Eniwetok.

8. Worn piece of a large segment, $\times$ 48. Paratype, USNM 40835 .

9. Nearly complete segment showing a little of the marginal perithallus as well as the thick medullary hypothallus, $\times 38$. Holotype USNM 40834 .

10-12. Corallina eniwetokensis Johnson, n. sp. (p. 940).

Miocene. Eniwetok.

10. Several worn fragments cut at various angles, $\times 48$. Paratype USNM 40827.

11. Several pieces, one shows a complete segment, a node, and character of the branching, $\times 48$. Paratype USNM 40827.

12. Three segments with the intervening nodes, $\times 48$. Holotype USNM 40828.

13. Dermatolithon marshallensum Johnson, n. sp. (p. 938).

Several specimens, one bearing a conceptacle, $\times$ 48. Miocene. Eniwetok. Holotype USNM 40826.

14. Lithoporella sp. A (p. 937).

- Small piece of a young plant, $\times 48$. Miocene. Eniwetok. USNM 40823 
GEOLOGICAL SURVEY

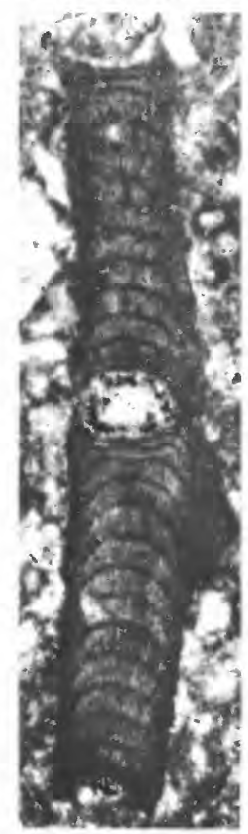

1

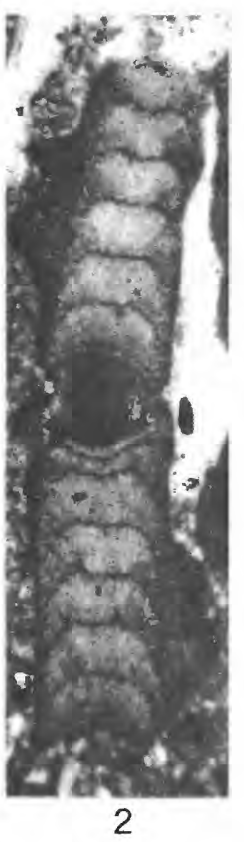

2
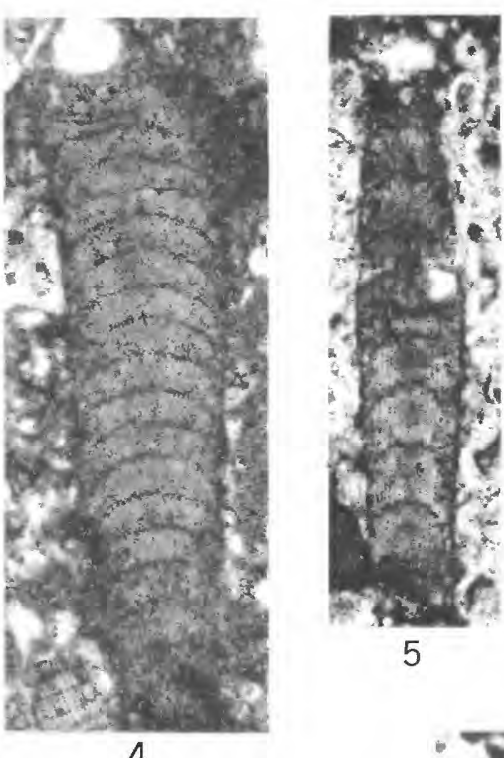

5

PROFESSIONAL PAPER 260 PLATE 277
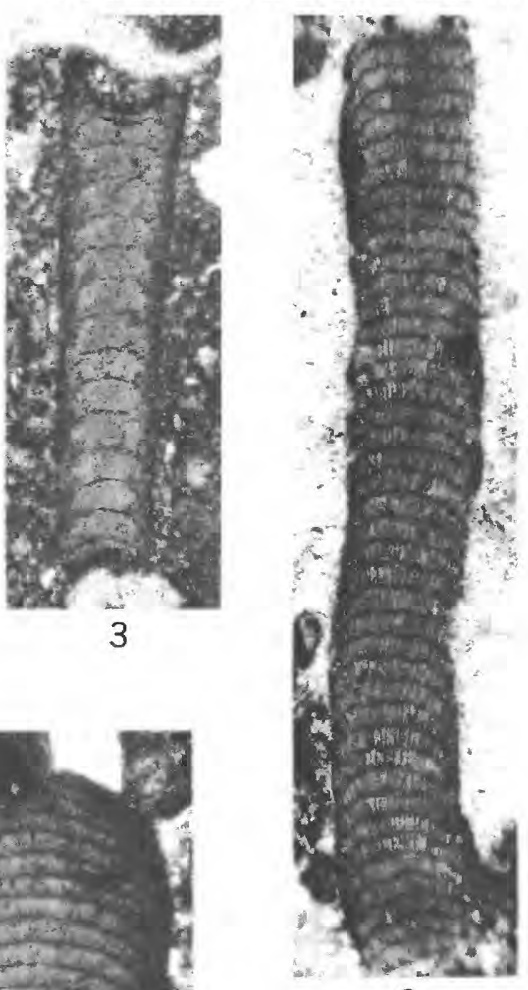

6

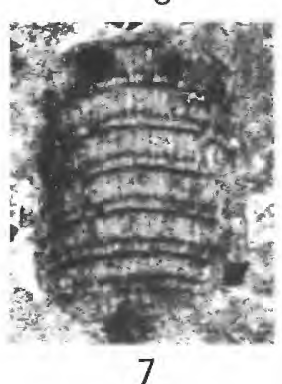

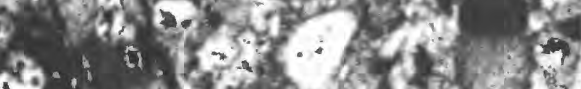

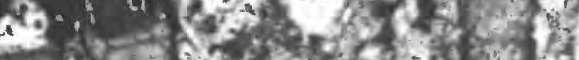

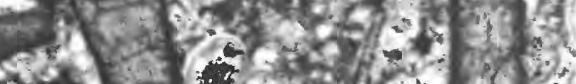
Sor the

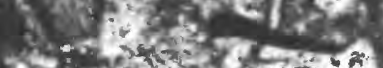

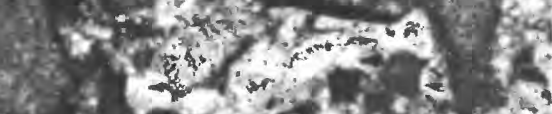

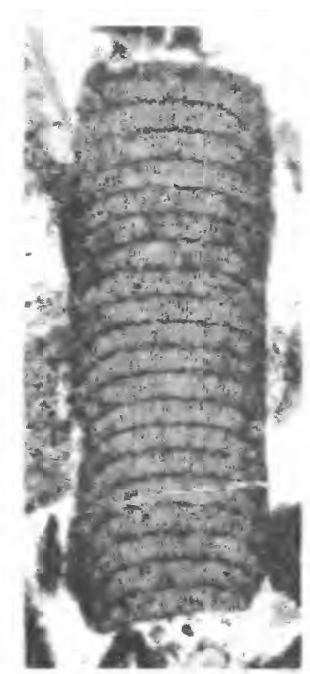

8
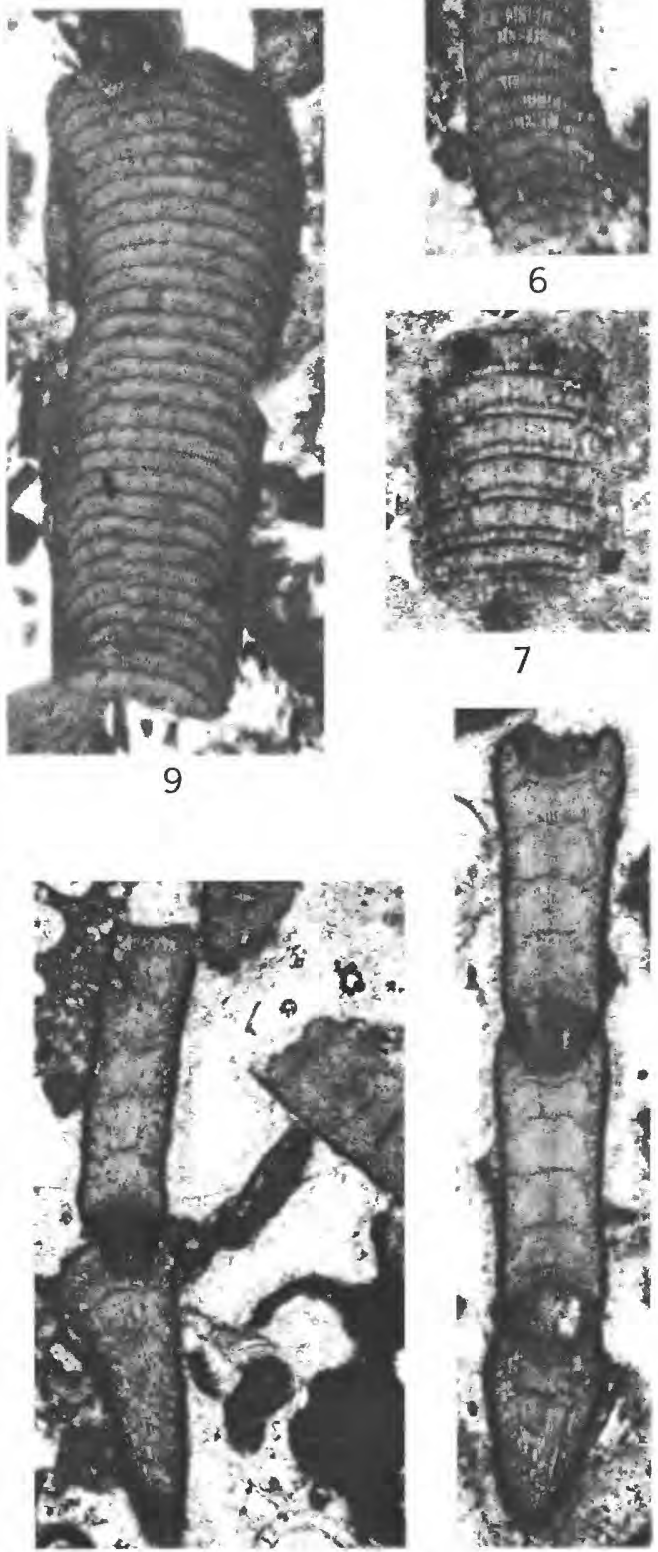

14

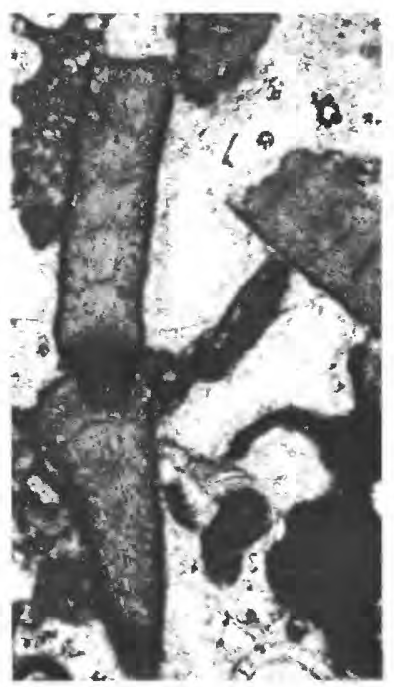

11 


\section{PLATE 278}

Figures 1-3. Amphiroa medians Johnson, n. sp. (p. 939). Miocene. Eniwetok.

1. Segment showing character of branching, $\times 48$. USNM 40915 .

2. A larger segment with branch, $\times 48$. Holotype USN M 40923.

3 . Several worn fragments, $\times 48$. USNM 40809 .

4. Jania sp. A (p. 939).

A nearly complete segment, $\times 48$.

Late Eocene. Eniwetok. USNM 40916.

5. Amphiroa sp. C (p. 940).

A branching segment, $\times 48$. Miocene. Eniwetok. USNM 40917.

6-8. Jania miocenica Johnson, n. sp. (p. 938).

Miocene. Eniwetok.

6. A long segment, $\times 48$. USNM 40918 .

7. A slightly oblique section of a small segment, $\times 48$. Holotype USNM 40919.

8. A fragment of a terminal segment showing a conceptacle chamber, $\times 48$. Holotype USNM 40919.

9-12. Dactylopora? sp. (p. 941).

Random sections of worn fragments, $\times 24$. Late Eocene. Eniwetok. USNM 40920 (figs. 10, 11, 12) and USNM 40921 (fig. 9). 
GEOLOGICAL SURVEY

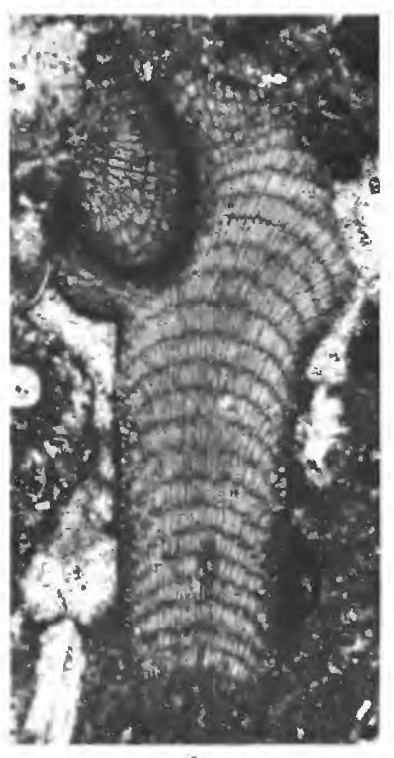

I

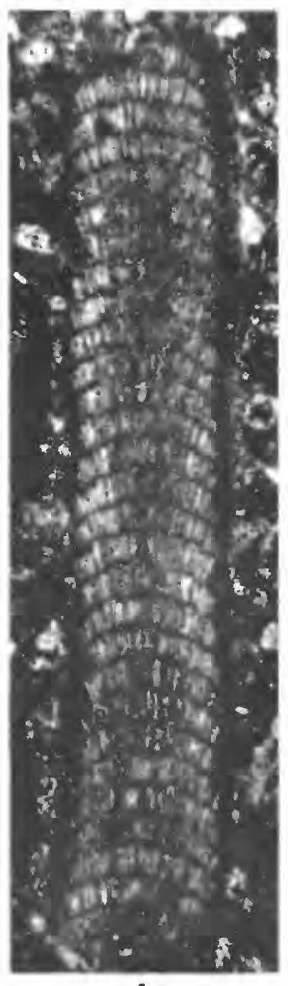

4

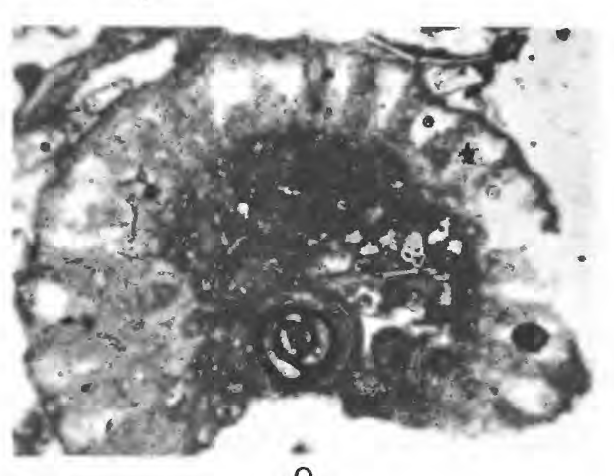

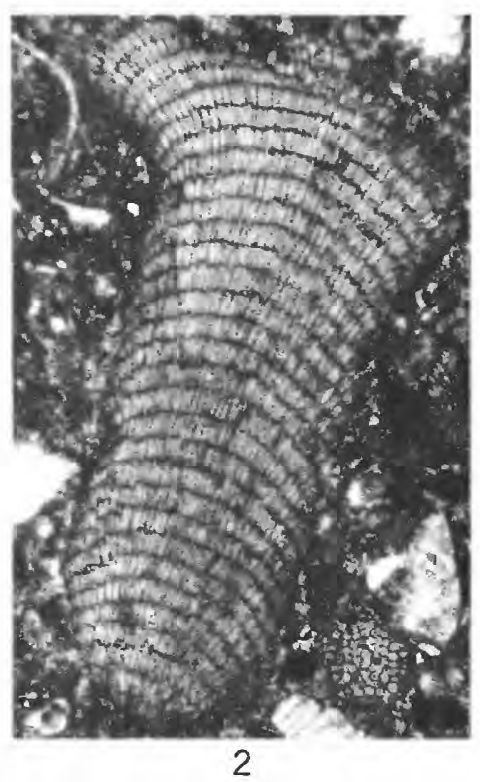

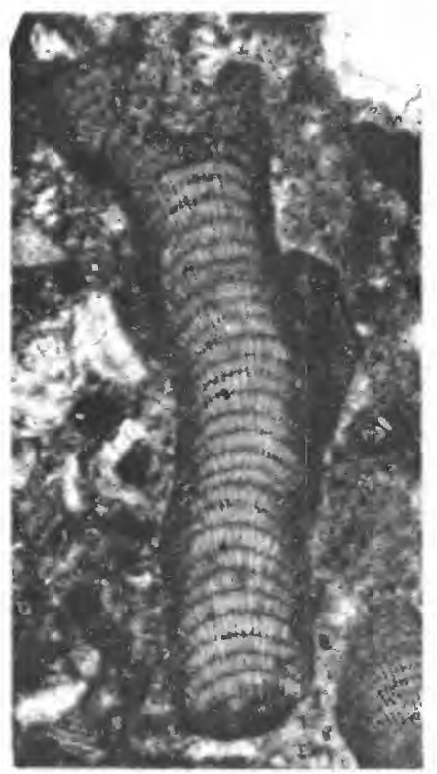

5

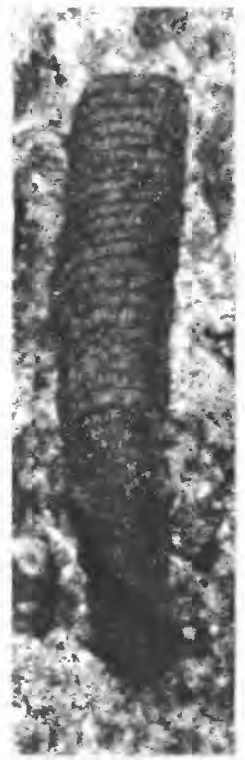

6
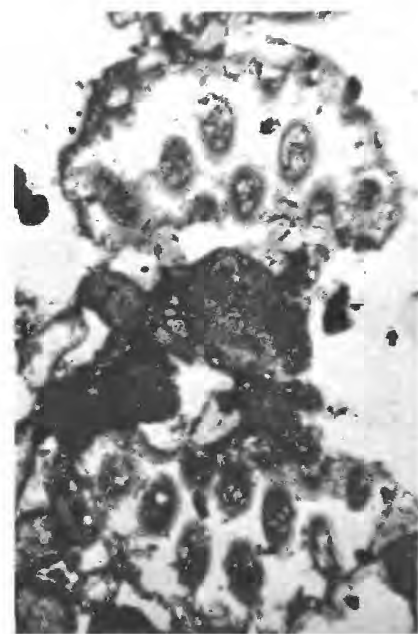

10

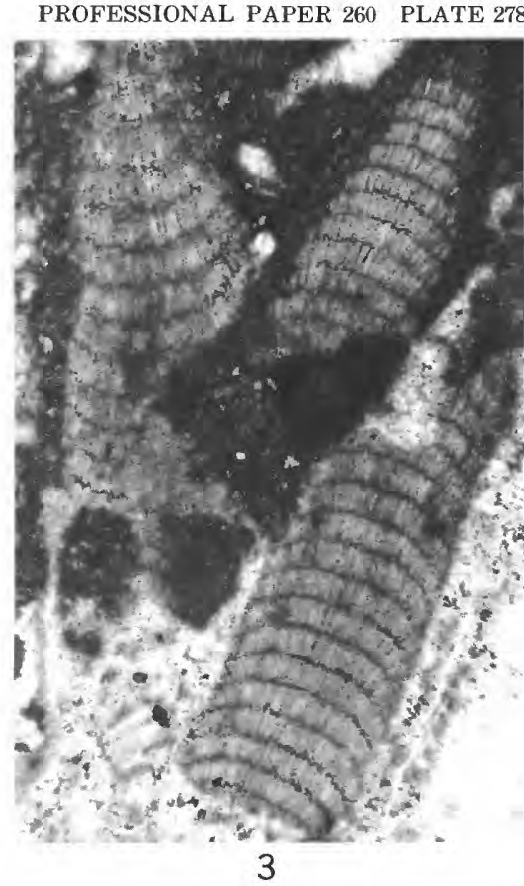

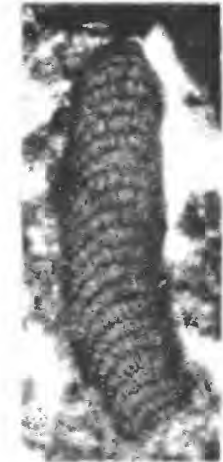

7

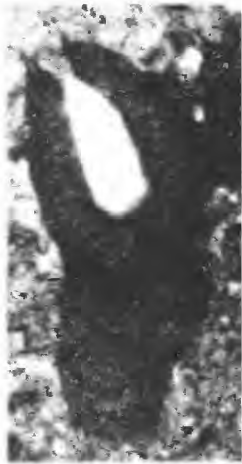

8
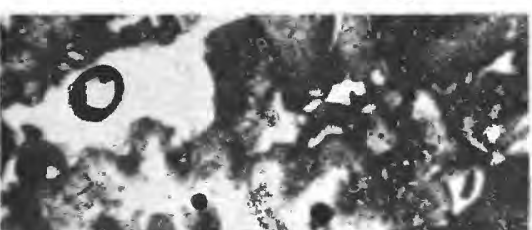

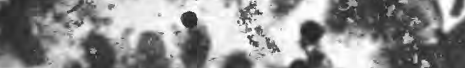

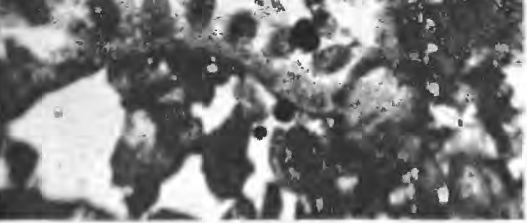

11

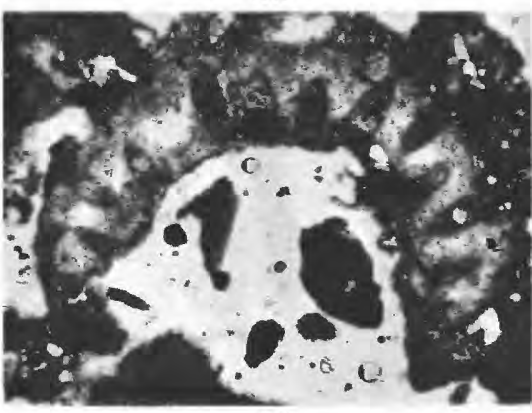

AMPHIROA, JANIA, AND DACTYLOPORA 
PLATE 279

Figure 1. Halimeda segments and coralline algae, $\times$ 14. (p. 942).

Pleistocene(?). Kita-Daitō-Jima.

2. Halimeda segments in limestone, $\times 1$. (p. 942).

Pleistocene(?). Eniwetok. USNM 40941.

3-5. Dactylopora? sp. (p. 941).

Late Eocene. Eniwetok.

3, 4. Nearly tangential sections, $\times 24$. USNM 40942.

5. A longitudinal section near the outer margin, $\times 24$. USNM 40921.

6, 7. Acicularia sp. (p. 941).

Numerous unoriented fragments scattered over the slides, $\times 14$. Late Eocene. Eniwetok. USNM 40944. 
GEOLOGICAL SURVEY

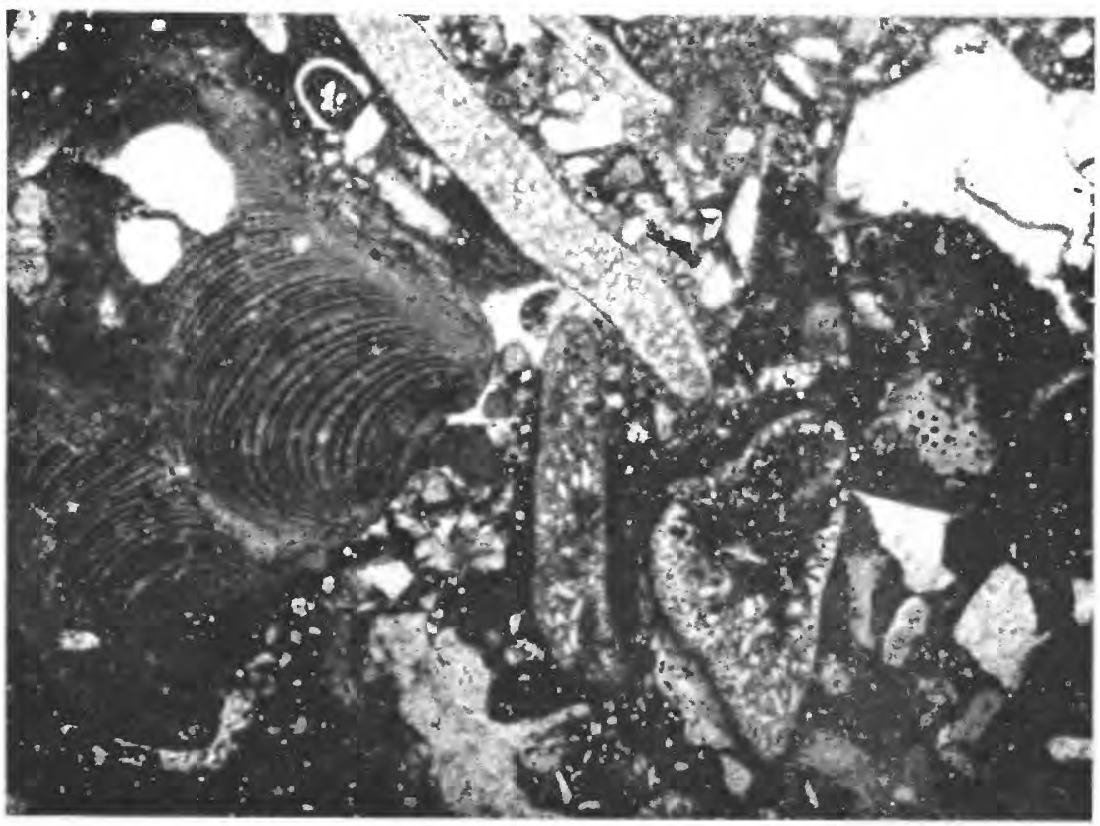

1

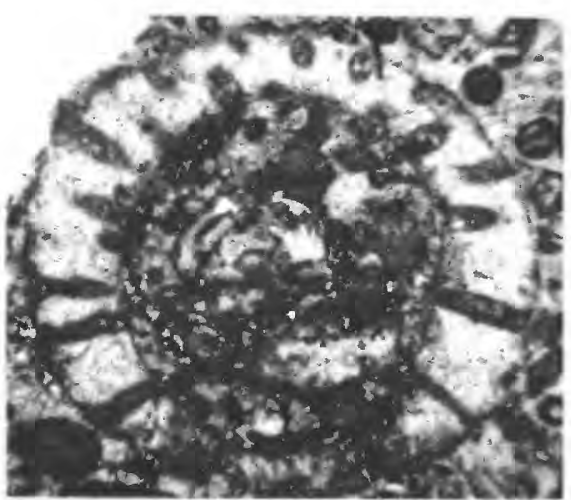

3

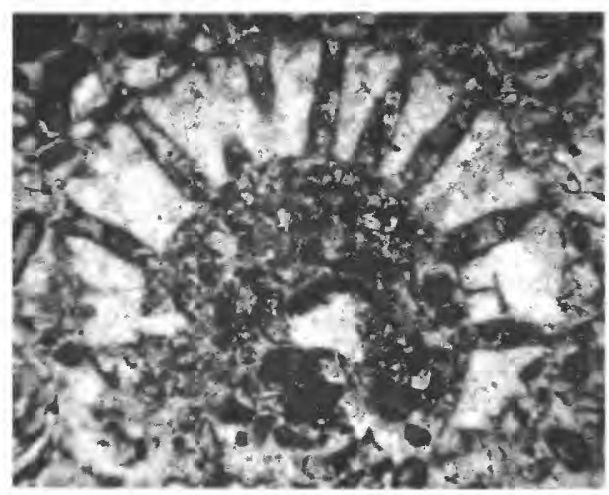

4

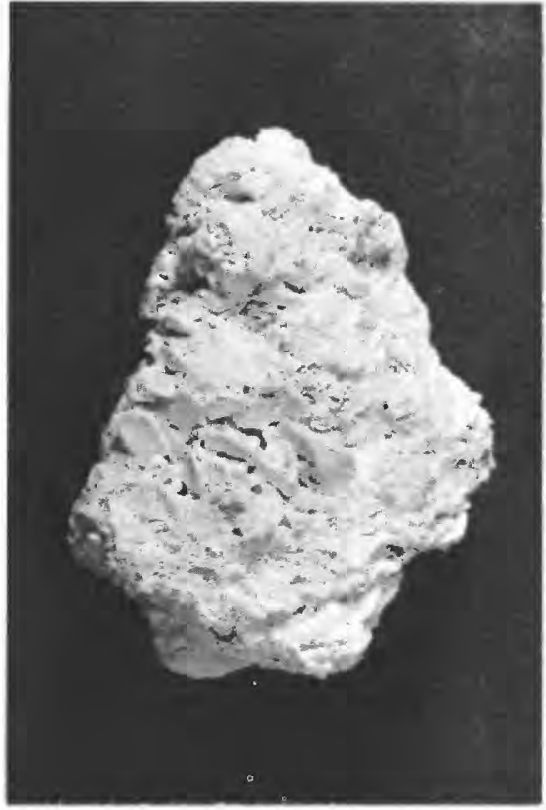

2

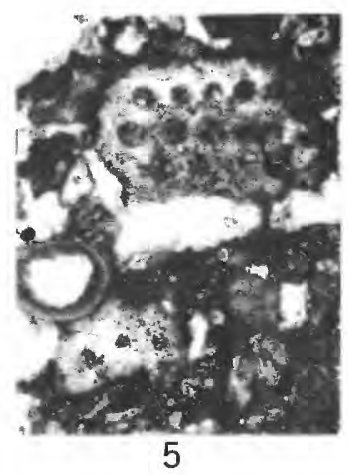

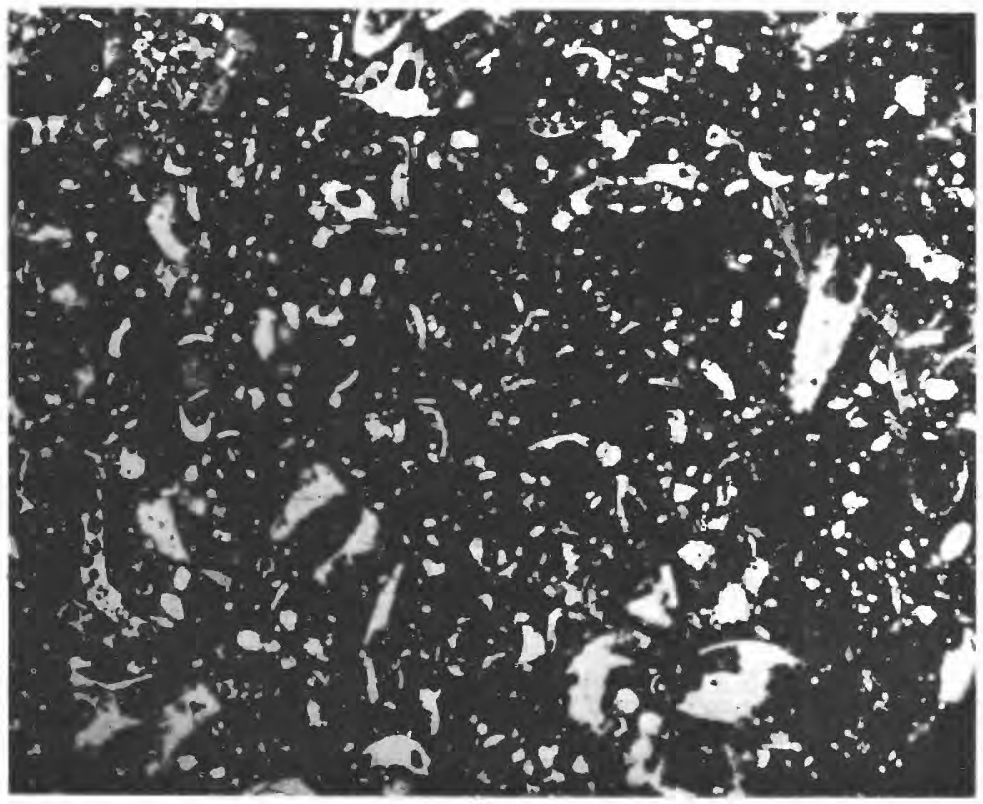

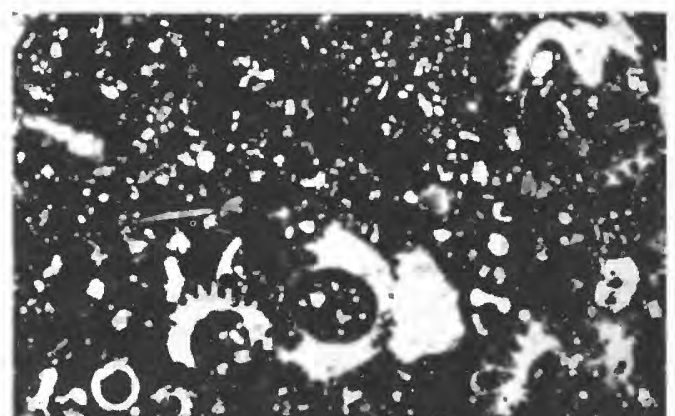

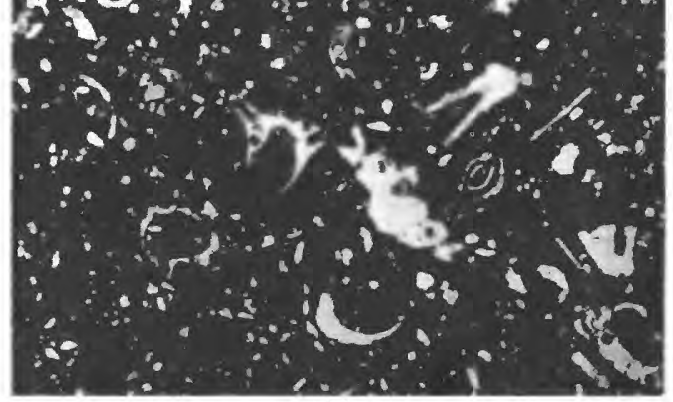

HALIMEDA, DACTYLOPORA, AND ACICULARIA 
PLATE 280

Figures 1-2. Numerous segments of Halimeda cut at various angles, $\times$ 14. (p. 942). Pleistocene(?). Kita-Daitō-Jima.

3-4. Segments of Halimeda badly recrystallized, $\times 38$. (p. 942).

Pleistocene or Recent. Funafuti core. 


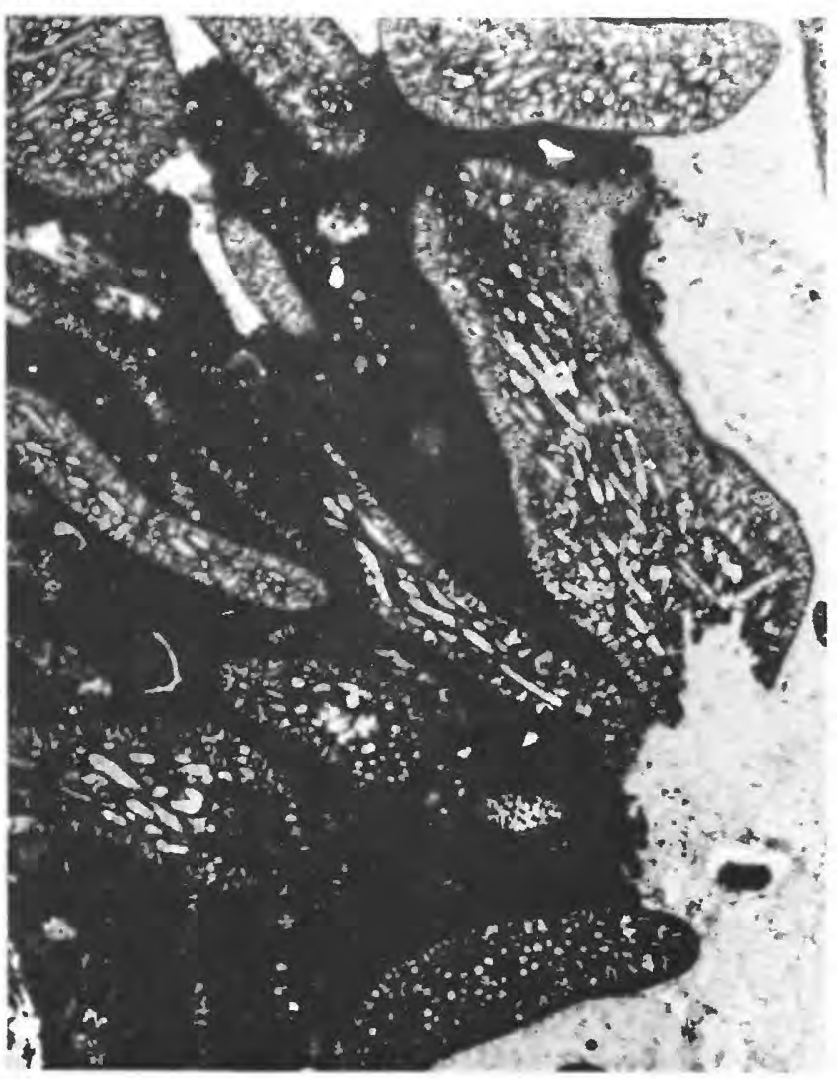

1

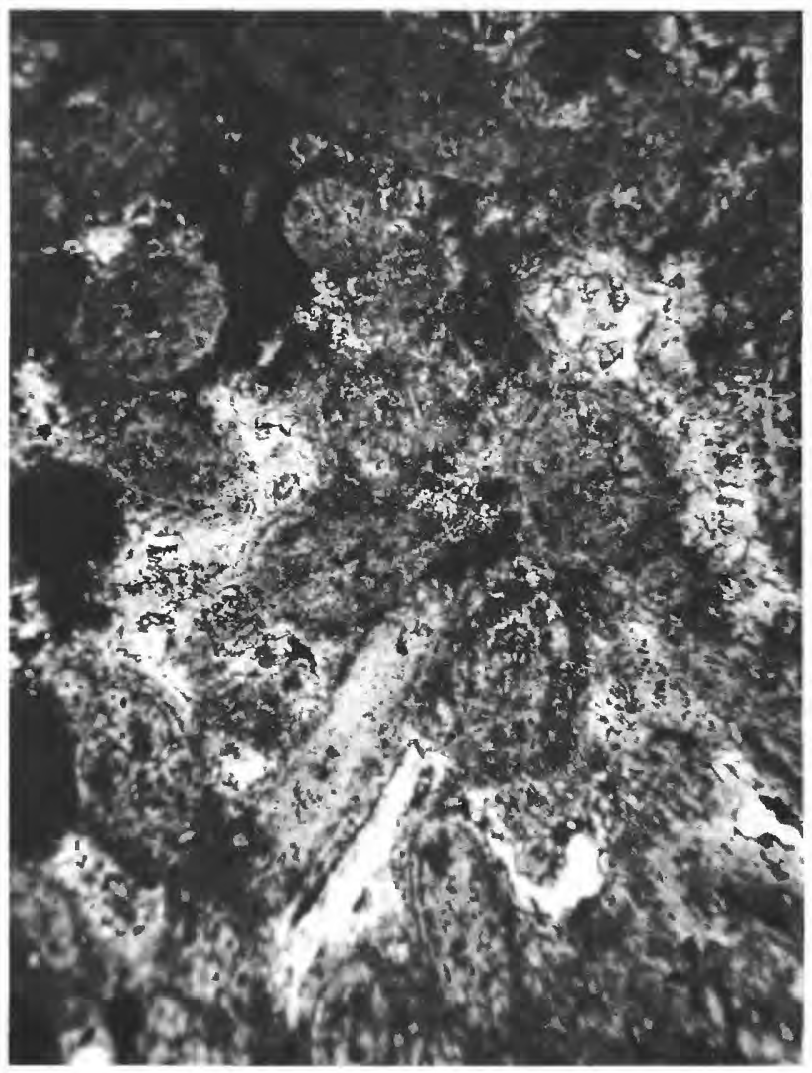

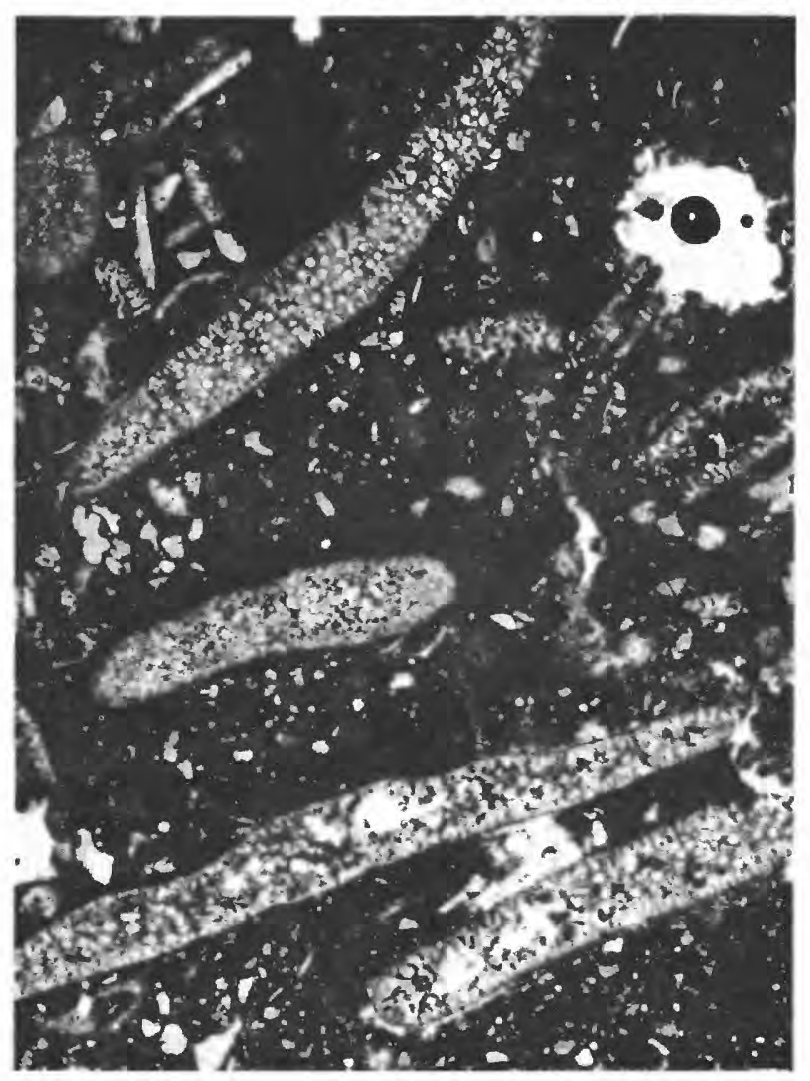

2

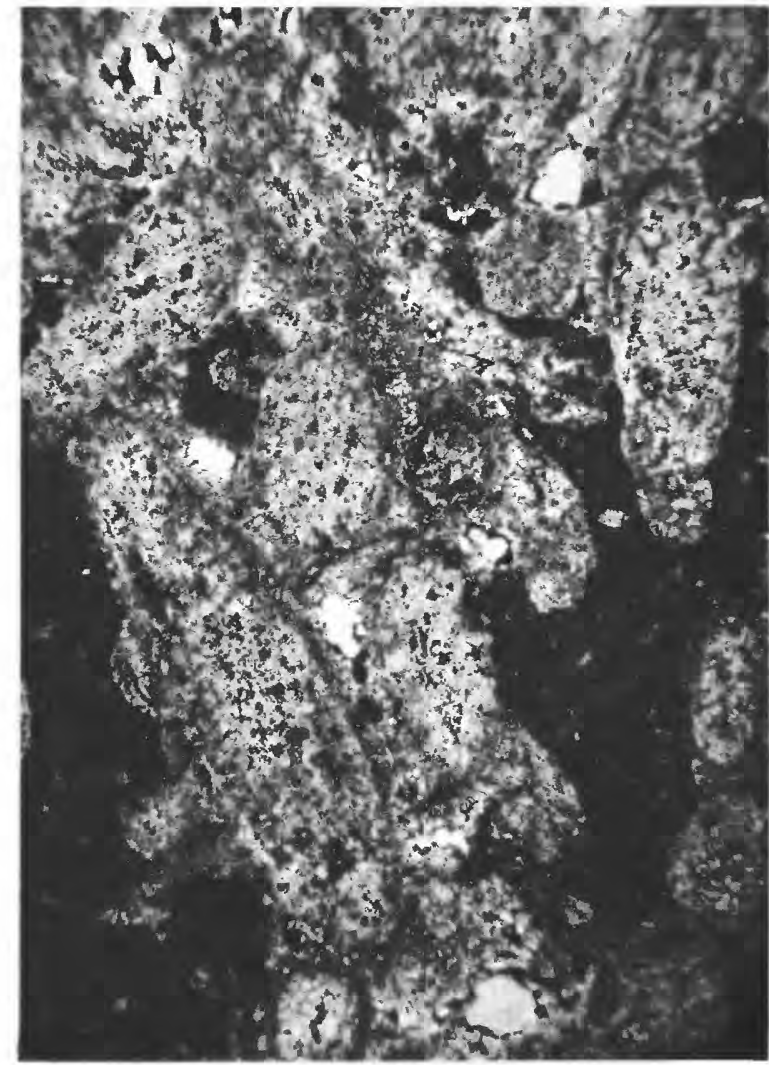

4 
